Natália Diniz da Silva

\title{
ESTABILIZAÇÃO DA TUTELA JURISDICIONAL DIFERENCIADA
}

Dissertação de mestrado apresentada ao Departamento de Direito Processual da Faculdade de Direito da Universidade de São Paulo, como requisito parcial para obtenção do título de mestre.

Área de concentração: direito processual

Orientador: Prof. Dr. Ricardo de Barros Leonel.

São Paulo

2014 
Autorizo a reprodução e divulgação total ou parcial deste trabalho, por qualquer meio convencional ou eletrônico, inclusive a publicação na Biblioteca Digital de Teses e Dissertações da USP (versão integral ou parcial) para fins de estudo e pesquisa, desde que citada a fonte.

Silva, Natália Diniz da.

Estabilização da tutela jurisdicional diferenciada/Natália Diniz da Silva - São Paulo, 2014. $227 p$.

Dissertação (Mestrado) - Universidade de São Paulo, 2014.

Orientador: Ricardo de Barros Leonel. 
Nome: SILVA, Natália Diniz da

Título: Estabilização da tutela jurisdicional diferenciada

Dissertação de mestrado apresentada ao Departamento de Direito Processual da Faculdade de Direito da Universidade de São Paulo como requisito parcial para obtenção do título de mestre.

Aprovado em:

Banca examinadora

Prof. Dr.

Instituição:

Julgamento:

Assinatura:

Prof. Dr.

Instituição:

Julgamento:

Assinatura:

Prof. Dr.

Instituição:

Julgamento:

Assinatura: 



\section{AGRADECIMENTOS}

Agradeço ao meu orientador, Professor Ricardo de Barros Leonel, pela ajuda imensurável para a redação desse trabalho. Aos professores Heitor Sica, José Roberto dos Santos Bedaque, Rodolfo de Camargo Mancuso e José Rogério Cruz e Tucci pelas ótimas ideias trazidas na qualificação desse trabalho, pela inúmeras dúvidas tiradas e pela disponibilização da biblioteca pessoal para a realização desse trabalho.

Ao meu namorado, Caetano Silva, que me apoiou durante esses três anos, me fez sorrir quando eu mais precisei e me deu forças para terminar este trabalho.

Aos meus pais, Silvania e Eliton, e à minha irmã, Tatiane, por entenderem a minha ausência em 2013 e por me darem todo o apoio nas horas mais difíceis.

Aos meus colegas do escritório SABZ Advogados, especialmente Paulo Araujo, Vinícius Loureiro e Gustavo Pereira, pela amizade e pelas ideias compartilhadas.

Aos meus amigos Viviane Siqueira, Patrícia Kobayashi, Vinícius Medeiros e Thiago Ermel pelo apoio e pela amizade. Sem todos vocês, a redação desse trabalho não seria possível. 



\section{RESUMO}

SILVA, Natália Diniz da. Estabilização da tutela jurisdicional diferenciada. Dissertação de mestrado. Faculdade de Direito, Universidade de São Paulo, São Paulo, 2014.

O escopo deste trabalho é analisar a tutela jurisdicional diferenciada, suas caracteríticas, limitações e utilizá-la como uma das soluções para a morosidade do Poder Judiciário. Para isso, investigaremos o próprio conceito de tutela jurisdicional, fazendo uma análise histórica e chegando ao conceito atual.

Após, estudaremos cada um dos tipos específicos de tutela jurisdicional diferenciada, examinando suas peculiaridades e problemática. Nesse capítulo estudaremos a tutela cautelar, antecipada e a de evidência (grande novidade incluída no projeto do novo Código de Processo Civil). Também estudaremos outras medidas de cognição sumária, apesar de esses outros tipos não apresentarem qualquer problema para se estabilizarem.

No capítulo 3 trataremos das características específicas da tutela jurisdicional diferenciada, principalmente da sumariedade na cognição, requisito essencial para esse tipo de tutela.

Em seguida, serão examinados os princípios constitucionais-processuais, como o devido processo legal e o princípio da igualdade e de como achar um equilíbrio entre a eficiência exigida pelo Estado e a duração razoável do processo, dever do Poder Judiciário e garantia dos jurisdicionados.

A questão da coisa julgada, da sucumbência e da fundamentação da decisão serão trabalhadas no capítulo 5. Pretendemos demonstrar nesse capítulo de como é possível outorgar força de coisa julgada para as decisões de cognição sumária, e não apenas a preclusão endoprocessual como prevista no projeto de novo Código de Processo Civil.

Por fim, analisamos as propostas legislativas já apresentadas pelo Instituto Brasileiro de Direito Processual e o projeto de novo Código de Processo Civil.

Ao longo do trabalho foram analisados a doutrina nacional e estudos de outros países, investigados a aceitação desses institutos e a recepção pelo Poder Judiciário, pelos advogados e pelos jurisdicionados. 
Palavras-chave: tutela jurisdicional diferenciada; cognição sumária, meios de aceleração do processo; projeto de novo Código de Processo Civil. 


\section{ABSTRACT}

SILVA, Natália Diniz da. Stabilization of non-ordinary court protection. Dissertação de mestrado. Faculdade de Direito, Universidade de São Paulo, São Paulo, 2014.

The scope of this work is to analyze the non-ordinary court protection, their characters, and limitations and to find a way to use it as one of the solutions to the slow pace of the Judiciary branch. For this, we investigate the concept of court protection, making an historical analysis up to the present concept.

After this, we study each of the specific types of non-ordinary court protection, examining their peculiarities and their problems. In this chapter we study provisional proceedings, evidence court protection (a new institute included in the project Code of Civil Procedure). We also study other non-ordinary proceedings.

In chapter 3 we study the specific characteristics of the non-ordinary court protection, mostly the summary cognition, an essential requirement.

Furthermore, we analyze the constitutional procedural principles, like due process of law, the principle of equality; and find a balance between efficiency and reasonable length of the proceedings, which is duty of the Judiciary branch and a guarantee of the population.

We also analyze the res judicata, loss of suit and opinion in chapter 5. In this chapter, we want to demonstrate the possibility of granting res judicata to non-ordinary court protection and not only to the preclusion of the process.

Ultimately, we analyze the legal proposes already presented by Instituto Brasileiro de Direito Processual and the project of a new Code of Civil Procedure.

In this work, we also study national doctrine and foreign legal writing. We investigate these new institutes, mostly the evidence court protection and the reception by the Judiciary branch, both from lawyers and the population.

Keywords: non-ordinary court protection, summary cognition, means to quicken the proceedings, project of a new Code of Civil Procedure. 


\section{SUMÁRIO}

\section{INTRODUÇÃO}

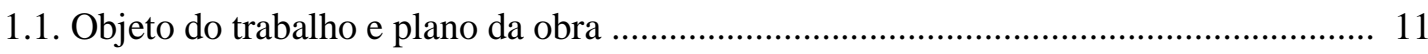

1.2. Delimitação do problema e arcabouço histórico .......................................................... 12

1.3. Crise do Poder Judiciário: soluções e princípios processuais ...................................... 14

\section{TUTELA JURISDICIONAL}

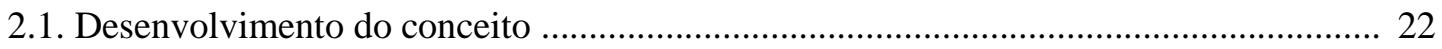

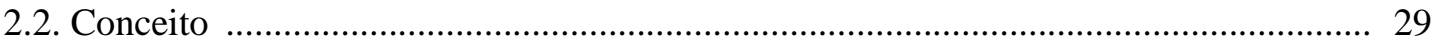

2.3. Tutela jurisdicional diferenciada ......................................................................... 37

2.3.1. Tutela de urgência ......................................................................................... 41

2.3.1.1. Tutela cautelar ................................................................................... 43

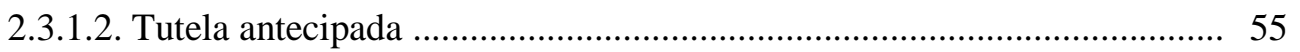

2.3.2. Tutela diferenciada não urgente …………................................................... 66

2.3.2.1. Tutela de evidência ............................................................................ 66

2.3.2.2. Outros procedimentos de cognição sumária ............................................ 80

2.3.2.2.1. Monitória ................................................................................. 81

2.3.2.2.2. Consignação em pagamento ........................................................ 94

2.3.2.2.3. Ações possessórias .................................................................... 95

2.3.2.2.4. Embargos de terceiro ...................................................................... 101

2.3.3.2.5. Mandado de segurança ................................................................. 103

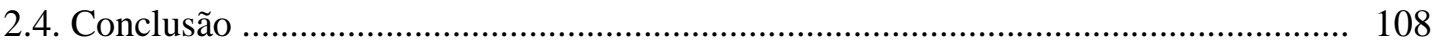

\section{TUTELA JURISDICIONAL DIFERENCIADA}

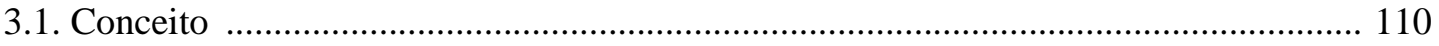

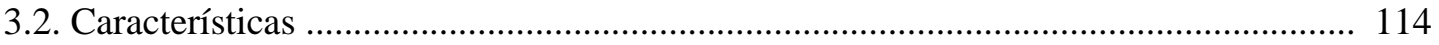

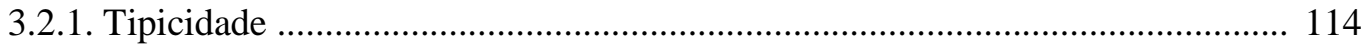

3.2.2. Limitação da cognição: sumarização da atividade cognitiva do juiz ................ 120

3.2.2.1. Sumarização do procedimento $\times$ sumarização da cognição .................... 127

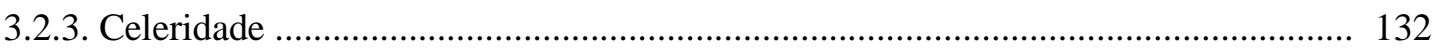




\section{PRINCÍPIOS PROCESSUAIS E}

\section{ESTABILIZAÇÃO DA TUTELA DIFERENCIADA}

4.1. Princípios processuais sob a ótica da estabilização ...................................................... 133

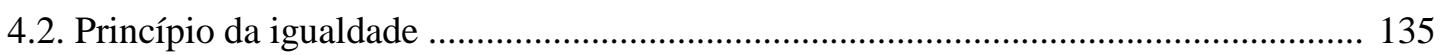

4.3. Princípio do devido processo legal ...................................................................... 140

4.4. Princípio do contraditório e da ampla defesa ............................................................... 142

4.5. Princípio da eficiência e da duração razoável do processo ........................................... 147

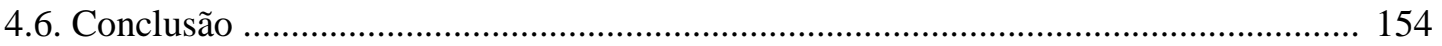

\section{ESTABILIZAÇÃO DA TUTELA DIFERENCIADA E}

PRAGMÁTICA PROCESSUAL

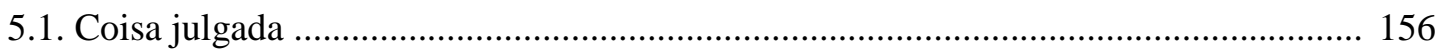

5.1.1. Estabilização com ou sem formação de coisa julgada ...................................... 163

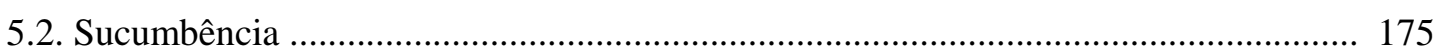

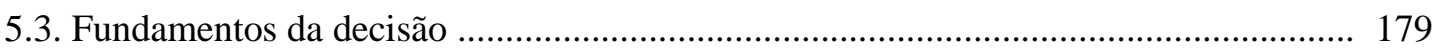

5.4. Críticas ao sistema: necessidade de criação de mais uma técnica? .............................. 182

\section{PROPOSTAS LEGISLATIVAS}

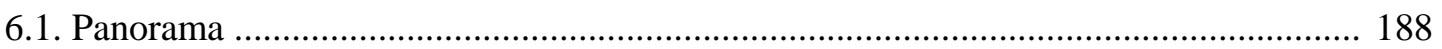

6.2. Proposta de estabilização apresentada pelo Instituto Brasileiro de Direito Processual 189

6.3. Projeto do novo Código de Processo Civil .................................................................. 195

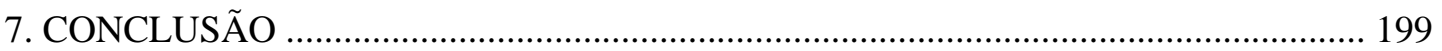

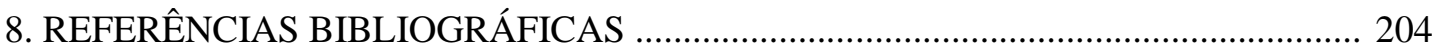

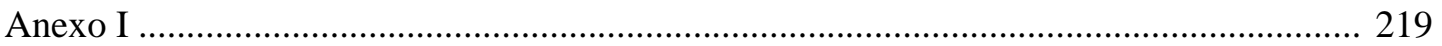

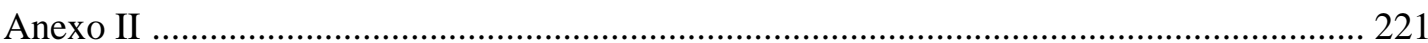




\section{INTRODUÇÃO}

\subsection{Objeto do trabalho e plano da obra}

Este trabalho tem como escopo analisar a possibilidade de estabilização, com ou sem formação de coisa julgada, da tutela jurisdicional diferenciada. Justifica-se a escolha do tema em razão da premente necessidade de se encontrarem técnicas de aceleração do processo e vencer a eterna batalha pela busca da efetividade das decisões judiciais.

A crise pela qual passa o Judiciário brasileiro faz-nos refletir sobre a real tutela jurisdicional, não apenas como prevista no art. $5^{\circ}$, XXXV, do Código de Processo Civil (CPC), mas conforme o atendimento das pretensões trazidas a juízo em tempo hábil, prezando igualmente as garantias processuais. Afinal, o processo é um instrumento de tutela do direito material e não pode ser utilizado como um fim em si. ${ }^{1}$ Deste modo, procurando atingir o verdadeiro escopo da jurisdição ${ }^{2}$ pretendemos analisar as diversas formas de tutela de cognição sumária. ${ }^{3}$

Para chegar a uma técnica mais adequada a essa realidade social, inicialmente analisaremos a evolução do conceito histórico de tutela jurisdicional até o presente. Como o objeto deste trabalho é a análise da tutela diferenciada, investigaremos as

1. "Segurança e celeridade, eis as palavras-chave para explicar o método ideal de solução das controvérsias" (José Roberto dos Santos Bedaque, Direito e processo: influência do direito material sobre o processo, p. 17).

2. Sobre o escopo da jurisdição, Cândido Rangel Dinamarco (Instrumentalidade do processo, p. 186) traça um interessante panorama: "Eis como e porque o correto enquadramento político do processo conduz à insuficiência da determinação de um escopo da jurisdição e mostra a inadequação de todas as posturas só jurídicas, que a todo custo buscam a resposta ao problema nos quadrantes do direito, sem descortinar o panorama sociopolítico em que inserida a própria função deste. [...] Por isso é que, hoje, todo estudo teleológico da jurisdição e do sistema processual há de extrapolar os lindes do direito e da sua vida, projetando-se para fora. É preciso, além do objetivo puramente jurídico da jurisdição, encarar também as tarefas que lhe cabem perante a sociedade e perante $o$ Estado como tal. O processualista contemporâneo tem a responsabilidade de conscientizar esses três planos, recusando-se a permanecer num só, sob pena de esterilidade nas suas construções timidez ou endereçamento destoante das diretrizes do próprio Estado social".

3. "A ciência processual deixou de ser um conjunto de princípios e regras técnicas apenas, para assumir caráter nitidamente instrumental, com a preocupação voltada para os fins a serem alcançados pelo processo. $\mathrm{O}$ estudo dos meios só se justifica na medida em que contribua para atingir resultados mais efetivos, eliminando a crise do processo, crise, essa, representada pela ineficiência do instrumento em relação aos seus escopos. Entre as várias alternativas, como a gratuidade da justiça para os necessitados, a simplificação da forma, a instituição de órgãos especiais para a solução de questões menos complexas, existe a tendência de adotar tutelas de urgência, destinadas a solucionar o litígio com maior rapidez, ainda que com limitações à atividade cognitiva do juiz, ou apenas a assegurar condições favoráveis à obtenção desse resultado pelas vias normais" (José Roberto dos Santos Bedaque, Tutela cautelar e tutela antecipada: tutelas sumárias e de urgência (tentativa de sistematização), p. 27-28). 
diversas espécies de tutela, dividas entre tutela de urgência, tutela não urgente e procedimentos especiais. Estudaremos cada uma de suas características, sempre concentrados na profundidade da cognição. Em seguida, passaremos ao exame das propriedades da tutela jurisdicional diferenciada e a sua importância para esta dissertação. Os princípios e garantias processuais também não poderiam deixar de ser analisados: a verdadeira tutela jurisdicional somente poderá ser entregue se forem respeitados todos os princípios e garantias constitucionais processuais, sob pena de voltarmos ao tempo do odioso processo do autor. Também serão estudadas algumas questões práticas e problemáticas da estabilização da tutela diferenciada, tais como: a possibilidade de se conferir força de coisa julgada à referida decisão; a estabilização com ou sem formação de coisa julgada; a sucumbência como forma de incentivar a não litigância; como a decisão deve ser fundamentada; e a necessidade de criação de mais uma técnica.

Por fim, serão submetidos à crítica a proposta de lei de estabilização da tutela antecipada apresentada pelo Instituto Brasileiro de Direito Processual (IBDP) e o projeto do novo CPC até a $6^{\mathrm{a}}$ Emenda Aglutinativa aprovada pela Câmara dos Deputados.

\subsection{Delimitação do problema e arcabouço histórico}

Preliminarmente, cumpre delimitar quais questões serão abordadas. Para tanto, é necessária uma breve análise histórica do próprio direito processual, de onde ele surgiu e para onde ele se dirige.

A ciência do direito processual tem origem no contex to do liberalismo capitalista, em meados do século XIX. Sua função era afirmar o papel dos Estados-países que estavam se consolidando e, consequentemente, confiar a jurisdição aos juízes. Estes nada mais eram que braços dos governantes, devendo apenas aplicar o direito à hipótese, sem interpretá-lo. ${ }^{4}$ Para manter o novo sistema funcionando, havia a

4 Cf. Ovídio Araújo Baptista da Silva, Curso de processo civil, vol. 1, p. 113. Quando criou a teoria da separação de poderes, Montesquieu cunhou a clássica expressão de juiz bouche de la loi (boca da lei). Considerando seu contexto histórico - de passagem de um Estado que era totalitário, centrado na figura do rei - é totalmente previsível a concepção de um juiz mais alheio e distante das questões sociais. Egas D. Moniz de Aragão (Hobbes, Montesquieu e a teoria da ação, Revista de Processo, ano 27, n. 108, p. 17-18), ao examinar toda a obra de Montesquieu, afirma que o juiz 
necessidade da certeza e da segurança do direito, uma vez que a burguesia do Estado liberal não poderia manter negócios sob o risco de ser surpreendida por uma decisão totalmente inesperada. ${ }^{5}$ Até o presente, a segurança e a certeza do direito são buscadas pelo processo civil: mais do que no século XIX, essa busca é ainda mais premente, pois o Poder Judiciário atende não apenas aos interesses da burguesia, que hoje equivaleria ao empresariado, mas também ao interesse de milhares de cidadãos que lhe recorrem diariamente. Decisões contraditórias, contrárias à jurisprudência dominante, situações de verdadeira injustiça não são desejadas pelo operador do Direito.

Para a maioria da população que busca uma solução perante o Judiciário, o processo em si é um instrumento de angústia. Por isso, a demora na solução acarreta tantos problemas quanto a ausência de solução: uma justiça que tarda e, por isso mesmo, falha. Findo o processo, há consequências na vida das partes, tais como realizar um pagamento, cumprir uma obrigação, deixar de fazer algo etc. ${ }^{6}$ Assim, qualquer que seja a solução dada pelo processo, quanto mais ela demorar, mais as partes ficarão insatisfeitas, e mais o Poder Judiciário terá de lidar com um problema social.

O processo é um instrumento de tutela de interesses. Por meio da jurisdição, o Estado entrega a tutela pleiteada às partes, suplantando seu interesse inicialmente conflitante com uma decisão proferida por um terceiro imparcial, que nada mais é que a concretização da norma abstrata contida no dispositivo legal. ${ }^{7}$ O Estado tirou das mãos dos particulares a possibilidade de autotutela e prometeu entregar a cada um dos cidadãos a paz social, fazendo o processo atingir seu escopo máximo. ${ }^{8}$

não era tão distante assim, pois, para aplicar automaticamente a letra da lei, ele deveria analisar a situação do caso concreto.

5. Essa certeza ainda é uma busca do próprio direito. Nenhum sistema processual consegue conviver com a ideia de decisões conflitantes - é o chamado efeito surpresa, que tanto se repudia.

6. "Nessa óptica em que prepondera a preocupação pelo resultado útil de cada experiência processual na vida comum das pessoas em relação com outras ou com os bens, levam-se em conta, de um lado, as pretensões insatisfeitas que impulsionam as pessoas a demandar e, de outro, o modo como fica essa pretensão depois do processo findo. São essas as duas pontas do iter de inserção do processo na vida em sociedade - ou seja, a realidade precedente ao processo, que legitima sua celebração, e a realidade sucessiva ao processo, criada por ele" (Cândido Rangel Dinamarco, Tutela jurisdicional, Revista de Processo, ano 21, n. 81, p. 72).

7. Cf. Antônio Carlos Marcato, Ação de consignação em pagamento, p. 49.

8. Marcato prossegue explicando a necessidade da atividade jurisdicional e o escopo primordial do processo: "Assim, a diferença fundamental entre a jurisdição e os aludidos equivalentes jurisdicionais reside no fato de a primeira representar, mediante o seu exercício através do processo, a substituição da ação direta contra o adversário pela ação dirigida contra o Estado, isto é, a conversão da ação física, própria da autodefesa, pela ação jurídica (jurisdicional) inerente à 
Nesse âmbito, entre a busca da segurança jurídica e a celeridade processual, está o presente trabalho. A escolha pelo tema da tutela jurisdicional diferenciada e a sua estabilização tem uma justificativa. A tutela diferenciada é aquela de cognição sumária, ou seja, atende a celeridade hoje tão buscada. No entanto, este estudo não pretende apenas tratar da tutela de cognição sumária, mas também buscar soluções para que a estabilização ocorra (mesmo com a outorga da coisa julgada), analisando outras questões de pragmática processual. Para tanto, será analisado também o próprio conceito de tutela jurisdicional, os diversos tipos de tutela de cognição sumária, a tutela diferenciada e os princípios processuais.

\subsection{Crise do Poder Judiciário: soluções e princípios processuais}

Uma vez exposto o surgimento do direito processual civil na sociedade industrial do século XIX como um meio de o Estado fortalecer seu poder, vale relembrar, sucintamente, as fases do processo civil e o seu desenvolvimento.

A primeira foi a fase sincretista, em que o processo era apenas um apêndice do direito material. Depois, passou-se à fase autonomista do processo, na qual se desenvolveu como ciência autonôma e, por fim, a fase atual instrumentalista, em que o processo serve como um instrumento para a realização do direito material. ${ }^{9}$

Como assevera Alvaro de Oliveira, ${ }^{10}$ o problema atual não é mais "reivindicar uma posição formal de autonomia do cidadão nas suas relações com o poder estatal", mas o "de assegurar ao cidadão a possibilidade de defender em concreto tais posições perante o Poder Público, em busca de igualdade material [...]”. Mais adiante, conclui o autor que "o direito vem agora considerado como fator institucional da vida econômica e social, vale dizer como instrumento de potencialização e equânimes, para

ideia de processo. E, quer se entenda que a jurisdição é o poder de atuar a vontade da lei no caso concreto - poder, este, conferido aos órgãos públicos a tanto destinados -, quer se entenda que a atividade jurisdicional tem por escopo a justa composição da lide, a verdade é que o Estado, retirando dos particulares o poder da justiça privada, assumiu a obrigação de tutelar, ainda que coativamente, os interesses daqueles, restabelecendo o equilíbrio e a harmonia sociais quando tais interesses sejam ameaçados ou violados" (idem, ibidem, p. 50).

9. Cf. Cândido Rangel Dinamarco, Fundamentos do processo civil moderno.

10. Carlos Alberto Alvaro de Oliveira, Os direitos fundamentais à efetividade e à segurança em perspectiva dinâmica, Revista de Processo, ano 33, n. 155, p. 11-26. 
a tutela, não mais formal, mas substancial, da dignidade e do desenvolvimento do homem, no âmbito da comunidade". ${ }^{11}$

E é exatamente essa a questão que será tratada no próximo capítulo. O conceito de tutela jurisdicional, hoje, não significa apenas acesso formal ao Poder Judiciário, mas a própria realização do Direito em tempo hábil. Esse é o desafio atual. Como respeitar os princípios processuais, mas também outorgar a tutela jurisdicional em tempo hábil?

Ao longo da história, tanto do processo civil como do próprio Direito como ciência, o legislador sempre teve como finalidade garantir a justiça civil. Como exemplo, podemos citar as exceptios do Direito Romano, criadas pelo pretor para solucionar problemas que não eram previstos nos sistemas de ações.

Hoje, a qualquer leigo que questione qual o maior problema do Judiciário todos responderão que é a morosidade na solução a ser oferecida. ${ }^{12}$ Dessa forma, sempre que os leigos ouvem falar em processo já imaginam que a culpa por toda essa demora e ineficiência do Poder Judiciário é da burocracia dos órgãos públicos e da quantidade complexa e mesmo infinita de recursos, que demoram anos para serem julgados - tratase do julgamento de questões processuais, que nada dizem sobre o mérito e aumentam ainda mais a insatisfação da população, para quem o processo é burocrático, demorado e, muitas vezes, falho. É um cenário verdadeiramente kafkaniano.

Ao contrário dos leigos, o estudioso do processo sabe muito bem que o processo é somente um instrumento e tal como qual ele deve ser utilizado para alcançar o objetivo para qual foi proposto: entregar a tutela jurisdicional. ${ }^{13}$ Ou seja, o processo é

11. “A grande preocupação da ciência processual contemporânea está relacionada, portanto, à eficiência da Justiça, que se traduz na busca de mecanismos para alcançar a efetividade da tutela jurisdicional. Na medida em que cabe ao Direito Processual a sistematização do método estatal de solução de controvérsias, devem os estudiosos dessa ciência voltar sua atenção para a criação de meios aptos à obtenção do resultado desejado" (José Roberto dos Santos Bedaque, Tutela cautelar e tutela antecipada: tutelas sumárias e de urgência (tentativa de sistematização), p. 15). Essa questão também é trazida por Comoglio: “Come sia consentito assicurare l'effetività della tutela giurisdizionale, quale requisito essenziale della giustizia in qualsiasi ordinamento giuridico socialmente avanzato" (Luigi Paolo Comoglio, Garanzie costituzionali e "giusto processo" (modelli a confronto), Revista de Processo, n. 90, p. 111).

12. José Rogério Cruz e Tucci (Tempo e processo, p. 15), ao comentar a demora do processo, assevera que este foi concebido para ter começo, meio e fim. No entanto, a demora tem sido tamanha que mais parece um evento milagroso: "Verifica-se, efetivamente, que em um número considerável de processos a espera do julgamento assemelha-se à expectativa, para alguns crentes da chegada do Messias...”.

13. Dinamarco (A instrumentalidade do processo) elenca os escopos que o processo deve atingir, a saber: social, político e jurídico. Não podemos nos esquecer de que o Direito é uma ciência humana e seu objeto de estudo maior são as relações humanas, seus conflitos e também sua solução, utilizando o Estado como intermediador. 
o meio pelo qual o Estado exerce a atividade jurisdicional e, por fim, entrega a justiça ${ }^{14}$ procurada. Não há dúvida também de que o processo não é o único vilão ${ }^{15}$ na morosidade e eficiência do Judiciário. Em grande parte, essa ineficiência se deve à própria mentalidade dos operadores do Direito, que inclui advogados, juízes e funcionários públicos. ${ }^{16} \mathrm{~A}$ ineficiência também se deve à própria estrutura burocrática do Judiciário, à falta de equipamentos necessários para a realização do trabalho, à ausência de metas a serem atingidas, ${ }^{17}$ à falta de capacitação e à ausência de motivação dos funcionário públicos, à má alocação de recursos humanos, à ausência de gestão, à ausência de informatização necessária etc. ${ }^{18}$

Desse modo, um dos grandes problemas do Judiciário brasileiro atual é como ser eficiente, entregando uma tutela jurisdicional em tempo razoável e respeitando todos os princípios constitucionais. Como tratamos aqui de técnica processual, não de

14. Não vamos analisar qual o significado de justiça, pois esse é um tema muito mais ligado à filosofia do direito que à ciência do direito processual. $\mathrm{O}$ termo justiça foi tratado aqui no seu significado mais amplo, ligado à ideia de que o particular foi buscar uma resposta no Estado para a solução do seu conflito e ao final de um procedimento o Estado entregou a resposta, qual seja, a justiça.

15. Acreditamos que o processo não é vilão, mas a solução: utilizado como instrumento, de forma inteligente, adequando cada procedimento às hipóteses trazidas pelas partes, ele pode ajudar em muito a resolver o problema de morosidade do Judiciário.

16. Para se ter uma ideia de como a mentalidade é algo extremamente importante, cumpre trazer um exemplo da vida real. Como advogada, uma vez ajuizei perante o Superior Tribunal de Justiça um conflito de competência e precisava que ele fosse distribuído o quanto antes ao Ministro responsável por despachá-lo. Na ocasião, liguei para o setor responsável pela distribuição e perguntei quando ela aconteceria. $\mathrm{O}$ funcionário responsável disse que antes de distribuir o processo (que, diga-se de passagem, é um procedimento digital) seria necessário autuá-lo, e isso levaria, no mínimo, três dias. Autuar -termo bastante comum para quem advoga - é o ato de colocar uma capa no processo e dividi-lo internamente, numerar, furar as folhas (isto em um processo físico, não digital). Na oportunidade, eu questionei o funcionário se haveria lógica para aquilo, uma vez que o processo era digital e bastaria apenas cadastrá-lo internamente e numerá-lo automaticamente pelo computador. Para minha surpresa, descobri que eles ainda faziam da maneira antiga. Enfim, o processo digital, no Superior Tribunal de Justiça é certamente o melhor do país: o sistema funciona perfeitamente e de maneira muito rápida. No entanto, ainda é necessário modificar a mentalidade dos operadores do direito para utilizarem a tecnologia a seu favor.

17. O que está sendo gradualmente modificado com as metas estabelecidas pelo Conselho Nacional de Justiça (CNJ) para a diminuição do acervo dos juízes.

18. Para se ter uma ideia, o processo digital pode gradualmente modificar esse quadro de ineficiência. Em uma ação ajuizada perante o Foro Central da Comarca de São Paulo em janeiro de 2013, ela foi sentenciada em abril de 2013. Em um tempo recorde de três meses, o autor ajuizou a ação, o réu foi citado e contestou, o autor apresentou réplica e as partes requereram o julgamento antecipado da lide por se tratar de questão de direito. Com essa experiência, fica claro que o processo, se bem utilizado, aliando-se à boa vontade das partes e do juiz, o Estado pode entregar uma tutela jurisdicional em tempo hábil e com qualidade. O processo digital existe para acabar com aqueles "tempos mortos" no cartório, em que o processo aguardava a juntada, a pilha da datilografia, a fila da conclusão etc. 
economia e gestão do Poder Judiciário, uma das soluções que propomos ${ }^{19}$ é a utilização da tutela diferenciada e a sua estabilização. Nos capítulos posteriores, demonstraremos que a tutela diferenciada pode ser facilmente identificada como aquela de cognição sumária. ${ }^{20}$ Para isso, serão analisados todas as tutelas que podem ser consideradas sumárias. $^{21}$

Nesse ínterim, ressaltamos que apenas nos últimos anos buscou-se sumarizar o processo e facilitar a cognição processual, afastando o procedimento ordinário que muitas vezes se revela moroso e somente mantém o status quo da situação, sem outorgar proteção alguma ao jurisdicionado. Durante muito tempo, aliás, o próprio conceito de ação esteve ligado à ideia de procedimento ordinário, de cognição exauriente com todas as fases processuais muito bem demarcadas. ${ }^{22}$ Desse modo, essa mudança na própria concepção de ação acompanha as necessidades da sociedade. ${ }^{23}$

Outro valor aspirado pelo Judiciário atual que deve ser considerado é a segurança jurídica. Busca-se, além um processo estático em que seja assegurado o direito ao contraditório, um "resultado qualitativamente diferenciado". ${ }^{24}$ Assim, seguindo a linha adotada por Carlos Alberto Alvaro de Oliveira, o processo justo decorre do respeito às garantias constitucionais, como o devido processo legal, mas também da garantia de uma tutela jurisdicional efetiva. Certamente, um dos grandes desafios do Poder

19. Não há dúvida de que a solução apresentada neste estudo seja pequena perto do problema de morosidade que o Poder Judiciário enfrenta hoje. De qualquer modo, é mais uma solução que, com outras, pode revolucioná-lo.

${ }^{20}$. José Roberto dos Santos Bedaque (Tutela cautelar e tutela antecipada: tutelas sumárias e de urgência (tentativa de sistematização), p. 28) enumera uma série de soluções para o problema da morosidade da Justiça: "Entre as várias alternativas, como a gratuidade da justiça para os necessitados, a simplificação da forma, a instituição de órgãos especiais para a solução de questões menos complexas, existe a tendência de adotar tutelas de urgência, destinadas a solucionar o litígio com maior rapidez, ainda que com limitações à atividade cognitiva do juiz, ou apenas a assegurar condições favoráveis à obtenção desse resultado pelas vias normais".

21. Sem necessariamente ser de um procedimento sumário.

22 'Na verdade, a teorização sobre o conceito de 'ação' processual escondeu sempre a proposição ideológica básica que a alimentava, e que tinha por fim legitimar a universalização do procedimento ordinário, como a única forma de tutela processual compatível com os valores e padrões culturais da civilização moderna, ao mesmo tempo em que - com um único golpe derrotava-se outro inimigo, contra o qual, na realidade, a luta se dirigia, quais sejam os processos sumários" (Ovídio Araújo Baptista da Silva, op. cit., p. 115).

23 Sobre o novo papel do processo civil, assevera Ovídio Baptista da Silva (op. cit., p. 123): "Segundo se diz, se a função do processo há de ser verdadeiramente instrumental, deverá ele ser concebido e organizado de tal modo que as pretensões de direito material encontrem, no plano jurisdicional, formas adequadas, capaz de assegurar-lhes realização específica, evitando-se, quando possível, que os direitos subjetivos primeiro sejam violados para, só então, merecer tratamento jurisdicional, concedendo-se a seu titular, às mais das vezes, um precário e aleatório sucedâneo indenizatório".

24 Carlos Alberto Alvaro de Oliveira, Os direitos fundamentais à efetividade e à segurança em perspectiva dinâmica, Revista de Processo, ano 33, n. 155, p. 22. 
Judiciário atual é como acelerar o processo sem correr o risco de abrir mão de uma decisão de qualidade.

Entre as finalidades do processo, conforme ensina Dinamarco, ${ }^{25}$ está a pacificação social. No âmbito processual, “é possível definir a adequação da tutela jurisdicional como a aptidão desta para realizar a eficácia prometida pelo direito material, com a maior efetividade e segurança possíveis". ${ }^{26}$ Portanto, em regra, a adequação resulta da ponderação desses dois valores ou direitos fundamentais, com vistas ao resultado que se quer obter diante da espécie de direito violado". ${ }^{27}$ Além disso, a segurança jurídica é um elemento de fortalecimento do Estado perante a sociedade - quando se começa a ter segurança jurídica os jurisdicionados começam a acreditar mais no Poder Judiciário.

De um lado, existe a tendência de sumarização do processo, como medida a acelerar a outorga da tutela jurisdicional; de outro, a busca eterna pela segurança jurídica, com decisões bem fundamentadas e que realmente atendam aos anseios daqueles que procuraram o Judiciário. Esses dois parâmetros guiam o Poder Judiciário para sustentar suas reformas e para lidar com seu maior dilema atual: a morosidade dos processos.

Essa não é uma tarefa e um desafio exclusivamente brasileiros. Na Itália, por exemplo, a reforma de 1999 introduziu na Constituição a garantia ao giusto processo, via critérios como o princípio da oralidade, a concentração do processo e - para assegurar a duração razoável do processo - a immediatezza. ${ }^{28} \mathrm{Na}$ União Europeia, a

25. Cândido Rangel Dinamarco, op. cit., 2008.

26. Efetividade e segurança jurídica são dois conceitos essenciais e que serão muito tratados ao longo desse trabalho. Podemos tratar a segurança jurídica como noção de previsibilidade, de não ser surpreendido. Assim, a segurança jurídica está ligada à previsibilidade do procedimento. $\mathrm{O}$ processo, como instrumento, tem um caminho natural, esse caminho deve ser seguido, sem sobressaltos, garantindo que as partes do processo tenham pleno controle sobre ele. Por outro lado, ainda está o conceito de efetividade, conceito ligado à eficiência (conforme previsto na Constituição) e eficácia. Conforme declara Paulo César Conrado (Efetividade do processo, segurança jurídica e tutela jurisdicional diferenciada, Revista do Tribunal Regional da $3^{a}$ Região, n. 76): "Falar de efetividade significa, por isso, falar de eficácia, jurídica e social, das normas que se projetam, no campo material, a partir do exercício da jurisdição; significa perscrutar, usando outros termos, sobre a (in)capacidade que tais normas ostentam de extravasar os muros do processo, penetrando os domínios do direito material (eficácia jurídica) de modo a modificar, factualmente, a conduta de seus destinatários (eficácia social)".

27 Carlos Alberto Alvaro de Oliveira, Os direitos fundamentais à efetividade e à segurança em perspectiva dinâmica, Revista de Processo, ano 33, n. 155, p. 24.

28 Comoglio, ao tratar da reforma que constitucionalizou o direito ao processo justo, trata da matéria em diversos planos, inclusive o político, no qual destaca um ponto interessante. Ao se declarar a constitucionalidade do processo justo, se reconhece o fato de que "il processo significare, sul piano politico, il riconoscimento solene del fatto che il processo sino a quel momento disciplinato dalle norme vigente fosse stato 'ingiusto', sia per colpa delle degenerazioni dell'ordinamento 
ideia de um processo justo remonta à década de 1950, quando se instituiu a Comunidade Europeia e foram então assegurados alguns direitos aos jurisdicionados, entre eles: direito de recorrer, sem sofrer grandes limitações; direito a uma efetiva defesa em juízo; garantia do contraditório; direito a produzir provas necessárias; publicidade da audiência e das decisões proferidas; independência e imparcialidade dos juízes; duração razoável do processo. ${ }^{29}$

A solução do problema não está em somente reformar a legislação com a finalidade de tornar o processo mais célere: também é necessária uma reforma estrutural no Poder Judiciário, através do processo eletrônico, contratação de mais magistrados e funcionários, incentivar a mediação para que as partes evitem recorrer à Justiça, garantir melhor estrutura e condições de trabalho aos seus funcionários. ${ }^{30}$

O processo em si sempre foi um fardo pesado tanto para o autor, que precisou acionar o Judiciário para ver seu problema solucionado, quanto para o réu, que muitas vezes é processado de forma injusta, tendo de contratar advogados e arcar com seus custos; também o é para o próprio Poder Judiciário, que deve movimentar toda a máquina estatal para a solução de problemas. Ainda, a não entrega da solução

giudiziario, sia per la progressiva erosione del modelo accusatorio, già introdotto nel CPP del 1988 in piena armonia con i principi costituzionali ed internazionali di giustizia" (Luigi Paolo Comoglio, Il giusto processo civile nella dimensione comparatistica, Revista de Processo, vol. 27, n. 108, p. 133-183).

29. O conceito de duração razoável do processo ainda é um tanto nebuloso. Quanto seria razoável? Giuseppe Tarzia analisa esse conceito e utiliza de uma sentença para definir o que seria razoável: "E' evidente, nelle sentenze della Corte europea, che l'esame del caso concreto viene condotto sulla base di alcuni criteri, costantemente ribaditi e rigorosamente applicati. La ragionevolezza della durata di un procedimento deve essere valutata alla luce dalla complessità del caso e del comportamento del ricorrente e delle autorità competenti. Così, tra le più recenti, la sentenza Laino c. Italia del 18 febbraio 1999, la quale aggiunge che 'nei casi che concernono lo status delle persone, l'importanza della controversia per il ricorrente è parimenti un criterio pertinente e inoltre si impone una diligenza particolare in considerazione delle eventuali conseguenze che una lentezza eccessiva può comportare, in particolare, sul godimento del diritto al rispetto della vita familiare" (Giuseppe Tarzia, L'art. 111 Cost. e le garanzie europee del processo civile, Revista de Processo, vol. 26, n. 103, p. 156-174).

30. Tarzia aponta ainda que grande parte da solução da morosidade do processo italiano não será alcançada via reforma legislativa, mas sim de reforma estrutural no Poder Judiciário: "Ognuno intende allora che il problema no si risolve soltanto sul piano delle regole del processo. La garanzia della ragionevole durata investe anzitutto l'organizzazione giudiziaria, nella sua più ampia accesione; impone al legislatore - sia esse il legislatore ordinario o il legislatore delegato - come al Govverno nell'esercizio del potere regolamentare, una congrua allocazione di uomini (magistrati, altri componente dell'ufficio giudiziario, ausiliari), di risorse e di mezzi per la funzionalità della giustizia; ed esige un adeguato apparato sanzionatorio nei confronti di chi colpevolmente violi il dovere di tempestività della tutela giurisdizionale" (idem, ibidem). 
jurisdicional traz um clima de instabilidade e desconfiança na Justiça, gerando também instabilidade política e, em alguns casos, convulsão sociopolítica. ${ }^{31}$

Reforçando essa posição, ainda em um viés mais sociológico, está a posição de José Eduardo Faria, para quem a eficácia da decisão judicial é importantíssima, sob pena de o Estado se enfraquecer e, consequentemente, iniciar um processo de desrespeito às normas e de mudanças legislativas, até mesmo da Constituição. Para o autor, o Judiciário tem um papel importantíssimo na afirmação e na segurança do Estado perante o povo:

\begin{abstract}
Cabe a uma magistratura com um conhecimento multidisciplinar, poderes decisórios ampliados e um processo mais flexível, uma dupla responsabilidade: tornar menos vaga e mais precisa uma ordem jurídica ambivalente e reformular - por via jurisdicional e a partir das próprias contradições sociais - os conceitos fechados e tipificantes dos sistemas legais vigentes. Tal responsabilidade não pode ser subestimada pela magistratura, sob pena de acabar vendo esgotadas, de modo progressivo, tanto a operacionalidade quanto o próprio acatamento de suas decisões em face da expansão dos conflitos coletivos. ${ }^{32}$
\end{abstract}

O juiz não pode mais ter uma postura passiva, pelo contrário: deve participar ativamente do processo, zelando por ele, garantindo o pleno contraditório às partes e dando a melhor decisão em um tempo adequado. ${ }^{33}$ Sua participação é necessária para que a tutela jurisdicional seja entregue no tempo adequado, ouvindo as partes, produzindo a prova. Essa participação ativa do juiz não significa, necessarimente, que ele seja parcial e esteja favorecendo uma das partes, mas apenas que ele se empenhe para resolver o processo e entregar a tutela jurisdicional.

Apesar de a longa duração dos processos ser inegavelmente um problema para o Estado, como é para o réu, sem dúvida ele é maior para o autor que terá de aguardar até o fim do processo (que, geralmente, leva anos) para ter uma solução judicial. O tempo - mesmo se fossem apenas horas - é sempre um dano ao autor, que necessariamente deve aguardar uma duração mínima para a outorga da tutela. ${ }^{34}$ Esse

31. Carlos Alberto Garbi, Tutela jurisdicional diferenciada e efetividade do processo, Revista dos Tribunais, ano 89, n. 782, p. 55.

32. José Eduardo Faria, Justiça e conflito.

33. Cf. Carlos Alberto Garbi, Tutela jurisdicional diferenciada e efetividade do processo, Revista dos Tribunais, ano 89, n. 782, p. 56.

34. Mesmo que esse tempo mínimo sejam algumas horas ou dias, o que abrangeria a elaboração da peça pelo advogado, a distribuição da ação no Judiciário (e todos os entraves burocráticos para fazer o processo "subir" ao juiz), a apreciação do pedido pelo Juiz e o efetivo cumprimento da decisão. Tudo isso poderia ocorrer de forma muito rápida, mas no momento que a decisão for cumprida podem ocorrer entraves burocráticos que inviabilizam o cumprimento da decisão e a 
tempo mínimo, que a doutrina denomina dano marginal, é o dano advindo da duração natural do processo, ${ }^{35}$ da permanência da insatisfação das partes (e, consequentemente, da existência do conflito) em razão da perpetução do estado de violação do direito. É o que Calamandrei chama de pericolo da infruosittà, no qual o remédio processual não é suficiente para acelerar a solução do problema. ${ }^{36}$

Esse perigo do dano marginal ocorre durante a tramitação do processo, quando o réu pode se despojar de todos os bens que seriam necessários para a satisfação do crédito do autor, ou as provas perecerem antes da realização da atividade probatória. Não há como escapar desse dano marginal, que é inerente ao processo. No entanto, há como impedir que ele se perpetue no tempo e evitar que a violação do direito prejudique ainda mais o autor.

Tal é o propósito deste trabalho: estudar maneiras de afastar o dano marginal, geralmente imputado ao réu, mas, também dar todas as garantias e encontrar, por fim, o sempre difícil equilíbrio entre efetividade da tutela jurisdicional, segurança jurídica e devido processo legal. Não é uma tarefa fácil, mas tampouco é impossível. O tema já foi discutido em diversos estudos, os quais pretendemos analisar para então acrescentar novas ideias a respeito do sistema jurídico brasileiro.

satisfação. Tenho duas experiências profissionais que ilustram isso. A primeira foi como advogada de uma empresa que atua no mercado de energia elétrica: o operador de sistema da empresa travara o programa necessário para a operação da compra e venda de energia, e, com esse travamento, a empresa ficou impossibilitada de realizar as suas operações, feitas exclusivamente através desse programa. Diante disso, ajuizamos uma ação de obrigação de fazer com tutela antecipada ao meiodia de uma sexta-feira; o juiz deu a tutela antecipada às dezesseis horas e às dezenove horas o réu foi citado e intimado a cumprir a tutela antecipada. No entanto, ele nada fez. Foi fixada astreinte, mas também não resolveu o problema, já que o réu não tinha patrimônio. A solução para o meu cliente foi simplesmente contratar outra empresa para solucionar o problema. É o exemplo típico de que a solução dada pelo Judiciário não foi efetiva, já que não satisfez o interesse do autor. O segundo exemplo foi uma liminar dada em uma ação de imissão na posse. O juiz deu a liminar no mesmo dia em que foi ajuizada a ação; no entanto, o cartório demorou uma semana para expedir o mandado de imissão na posse, e o oficial de justiça demorou mais uma semana para cumpri-lo. Igualmente, a tutela outorgada pelo Judiciário não foi efetiva, já que a cada dia que passava o dano ao autor era maior.

35. "Una conseguenza diretta ed immediata della semplice permanenza, durante il tempo corrispondente allo svolgimento de processo, dello stato di insoddifazione del diritto, o cosa che è lo stesso, di quella concreta situazione lesiva che si è visto stare all'origine del processo" (Enrico Finzi, Questioni controverse in tema di esecuzione provvisoria).

36. Piero Calamandrei, Introduzione allo studio sistematico dei provvedimenti cautelari, p. 54. 


\section{TUTELA JURISDICIONAL}

\subsection{Desenvolvimento do conceito}

Primeiramente, faremos uma retrospectiva histórica do próprio conceito de tutela jurisdicional, para se chegar ao conceito atual. No direito romano, só existia direito se existisse uma actio - era um sistema baseado em ações, não no direito material. Em muitas situações, o cidadão não possuía um meio de buscar o seu bem violado, pois não existia uma ação correspondente. ${ }^{1}$ Assim, a actio "era o único direito concedido para a tutela dos interesses".2 Nessa época, não existia uma diferença substancial entre direito material e processo e, aliás, a actio era considerada uma derivação do direito material. Este somente passaria a existir caso existisse a previsão de uma actio específica; antes disso, não existia um direito subjetivo material.

Apesar de o sistema de ações do direito romano ter sido extremamente fechado, na mesma época já surgiram interditos e actios específicos que permitiam a antecipação dos efeitos da tutela em algumas situações. É o caso da actio exhibendum, que nada mais era que exigir a exibição da coisa pleiteada perante o pretor, com o mesmo espírito da medida cautelar de exibição de documentos. Era um procedimento anterior à ação real ou o interdito utrubi, quem fosse ajuizar uma dessas duas ações poderia valer-se da actio exhibendum para exigir a exibição da coisa daquele que a detinha. Se o réu não quisesse fazer parte da ação, o pretor facultava ao autor a possibilidade de este ficar com a posse da coisa, para somente após ser investigada a propriedade. $^{3}$

A distinção entre direito material e processo surgiu somente no século XIX, com a polêmica entre Bernhard Windscheid e Theodor Muther. O primeiro fez uma distinção entre a actio romana e a acción, ${ }^{4}$ e sua grande contribuição foi elaborar o conceito de pretensão: uma situação jurídica substancial distinta da ação no sentido

1. Cf. José Rogério Cruz e Tucci, Lições de história do processo civil romano.

2. Carlos Alberto Alvaro de Oliveira, Efetividade e tutela jurisdicional, Revista Forense, vol. 101, n. 378, p. 113-133.

3. Cf. Carlos Alverto Alvaro de Oliveira, Perfil dogmático da tutela de urgência, Revista Forense, vol. 94. n. 342, p. 13-28. O autor traz ainda diversos outros exemplos, como bonorum possessio ex carboniano, bonorum possessio ao nasciturus, officius consulis, missio antoniana etc.

4. Giovanni Pugliese, Polemica sobre la actio, p. XIII. 
processual e não identificável com o direito subjetivo do qual era mais uma emanação. ${ }^{5}$

Para Windscheid, a actio tem dois significados: a pretensão perseguida em juízo e o poder de perseguir a pretensão em juízo. ${ }^{6}$ Portanto, como salienta Pugliese, "los dos significados son incompatibles entre si", ${ }^{7}$ pois são situações distintas e, conforme Windscheid, se a actio é o poder de perseguir em juízo não é possível também que signifique pretensão, que é o direito de fazer valer a máxima de Celso - id quod sibi debeatur.

Na concepção dos romanistas, como demonstrado, a actio era o poder de acionar um processo, de iniciar uma demanda. Não existia o conceito de direito subjetivo, mas somente as ações previstas. Muther, outro professor alemão, criticou de forma veemente as considerações de Windscheid. Para ele, a actio era o direito a uma tutela judicial, ${ }^{8}$ um direito de natureza pública do lesado para buscar satisfação perante o Estado e pelo qual este prestaria a tutela jurídica. ${ }^{9}$ Definida assim, como um direito per se, não se corria o risco de confundi-la com o direito subjetivo.

Foram incorporados novos conceitos após as críticas de Muther, e passou a se distinguir um direito à tutela estatal - o direito de agir - além do direito material intocado. A partir dessa ideia, Windscheid reconhece a existência de um direito de

Idem, ibidem, p. XV.

6. Conforme Pugliese (op. cit.), Windscheid trabalha com dois conceitos de actio que se alternam: "Bien la actio es para él la pretension perseguible en juicio, bien es en cambio el poder de perseguir en juicio la pretensión".

7. "Pero esta atribución a la actio de un contenido estrictamente sustancial es causa de graves perplejidades. Perplejidades no disipadas, sino que se han hecho más complejas con acto lo he nosotros expresamos con pretensión, habrían aludido no obstante al mismo tiempo a la persecución judicial. Una de dos: o la alusión a la tutela judicial no significa otra cosa que la pretensión ha de entenderse como perseguidle en juicio y entonces la advertencia es inútil, desde el momento en que no puede existir al respecto ninguna diferencia entre la noción romana y la moderna, pascuales ponen igualmente entre los caracteres de las relaciones jurídicas la posibilidad de ser tutelados mediante el recurso al juez y colocan, por consiguiente, en una distinta categoría las relaciones de obligación natural; o, por el contrario, la alusión tiene un significado más preciso, como resultaría del concepto de que la action (como acto) no es otra cosa que la persecución judicial y entonces la advertencia contradice a la tesis, puesto que la actio (como situación jurídica) terminará necesariamente al aparecer el poder de cumplir o de promover aquella persecución judicial, y no podrá hacerse ya coincidir con la pretensión que, según el presupuesto de Windscheid, no es el poder de perseguir em juicio, sino el derecho al comportamiento ajeno" (idem, ibidem, p. XXX).

8. "Para Muther, la actio no era, pues, un apéndice o un complemento del derecho subjetivo (como pensaban Bocking y Puchta) ni el nuevo derecho a un comportamiento del adversario surgido de la violación de un derecho precedente (según el critério de Savigny), ni, finalmente, el equivalente romano de la pretensión en el sentido de Windscheid, sino el derecho al libramiento de la fórmula, o, más ampliamente, el derecho a la tutela judicial" (idem, ibidem, p. XXXIII).

9. Sobre os questionamentos de Muther, Pugliese faz a seguinte crítica: "En cambio, la parte constructiva, que se concretaba en definir la actio como el derecho frente al magistrado al libramiento de la fórmula en configurar, en general, un derecho frente al Estado a la prestación de la tutela jurídica, tuvo amplias repercusiones" (idem, ibidem, p. XIX). 
ação material com uma ação processual. O primeiro é a própria pretensão jurídica material contra quem praticou a lesão, e o segundo é o direito a uma tutela estatal.

No começo do século XX, o direito processual ainda deu outro grande passo com a teoria defendida por Adolf Wach: “[...] ao estabelecer um direito concreto de demandar, que se consubstancia na chamada pretensão à tutela jurídica, formada com elementos de direito material e processual, devendo a ambos unir. [...] Trata-se, portanto, de uma pretensão de direito público, cujo conteúdo é a finalidade de obtenção de tutela jurídica". ${ }^{10}$

A doutrina proposta por Wach foi amplamente aceita, mas foi rejeitada com o tempo, pois suas ideias nem sempre correspondiam à realidade. ${ }^{11}$ Wach determinou o caráter concreto e público da ação. O caráter público está ligado ao fato de que o Estado exerce o controle da ação, enquanto o caráter concreto deriva da eficácia que tem a ação contra o adversário. No entanto, o conceito de Wach peca por um lado: somente há ação se a sentença for favorável ao autor. Conforme Alvaro de Oliveira: "Leo Rosenberg bem resume as críticas realizadas na Alemanha à teoria de Wach. Ambas as partes têm pretensão à outorga de justiça, não apenas uma delas, mas não a uma tutela jurídica favorável". ${ }^{12}$ Podemos ver que esse pensamento se aproxima ao pensamento moderno de tutela jurisdicional. ${ }^{13}$

Leo Rosenberg, ao iniciar sua tese sobre o papel do próprio processo civil (que ainda não tinha se desenvolvido como o conceito de tutela jurisdicional), é claro ao afirmar que o objetivo do processo civil é manter a paz jurídica e não somente entre as partes, mas também para o próprio Estado. ${ }^{14}$ Inclusive, o autor afirma que tal é o fim

10. Carlos Alberto Alvaro de Oliveira, Efetividade e tutela jurisdicional, Revista Forense, vol. 101, n. 378, p. 113-133.

11. Segundo a teoria de Wach, a tutela do Estado correspondente a uma sentença favorável: “Acaso la falta cardinal del concepto de la relación jurídica procesal consista en que es puramente abstracta, es decir, que en ella se echa de menos toda conexión con el objeto del proceso que es, por lo regular, el derecho subjetivo material protegido por la acción. Esta tacha dio lugar a que Wach estableciera el concepto de la exigencia de la protección jurídica (Rechtsschutzanspruch). Wach entiende bajo tal denominación el derecho subjetivo público procesal de la parte, titular, según el derecho material, frente al Estado, a que le dé protección jurídica mediante una sentencia favorable (que en caso de ser condenatoria lleve aparejada ejecución), y frente al adversario, a que éste sufra el acto protector estatal)" (Cf. James Goldschmidt, Principios generales del processo, vol. 1, p. 27.

12. Carlos Alberto Alvaro de Oliveira, Efetividade e tutela jurisdicional, Revista Forense, vol. 101, n. 378, p. 113-133.

13. Esse é o entendimento de Flávio Luiz Yarshell, Tutela jurisdicional.

14. Cândido Rangel Dinamarco desenvolve brilhantemente a questão do escopo do processo no livro A instrumentalidade do processo, no qual vai muito além da paz jurídica mencionada por 
da criação do próprio Estado: garantir a paz de seus cidadãos. ${ }^{15}$ Rosenberg afirma que é papel do Estado prestar a administração da justiça para as partes e que estas têm direito a uma outorga da tutela jurisdicional. É como se as partes tivessem o direito de exigir do Estado a prestação do serviço jurídico. ${ }^{16}$ No entanto, a obrigação do Estado para por aí: ele é obrigado a prestar a tutela jurisdicional, mas esta não significa que a sentença tenha de ser favorável a quem a pleiteou. O Estado está apenas obrigado a prestar a tutela jurisdicional, decidindo a questão com os elementos trazidos nos autos, não importando se o resultado favorável é para o autor ou réu. ${ }^{17}$

Oskar Bülow criticou igualmente a teoria de Wach ao afirmar que não poderia existir uma sentença favorável antes e fora do processo, e que só no fim do procedimento o juiz tem condições de proferir seu juízo de valor, com uma sentença favorável ou não. ${ }^{18}$ Bulöw propôs que o direito processual tem uma relação jurídica pública com o Estado e o indivíduo ${ }^{19}$ e, com base nesse princípio, concebeu a teoria dos pressupostos processuais em sua obra mais importante.

Ainda, como ensina Alvaro de Oliveira, é James Goldschmidt quem dá uma nova roupagem às ideias de Wach ao desenvolver a teoria do direito justicial (Justizrecht), o qual "tem como objeto uma relação jurídica entre a justiça estatal e a pessoa individual". ${ }^{20}$ Goldschmidt afirma que, ao contrário da época do direito romano clássico, no moderno processo civil o juiz tem a obrigação de conhecer a demanda, e

Rosenberg para analisar os outros aspectos da prestação da tutela jurisdicional e sua importância no Estado Democrático de Direito.

15. "Precisamente el proceso civil sirve no sólo a las partes para la consecución de sus derechos, sino que, mediante la resolución firme apetecida de la cuestión jurídica controvertida, sirve especialmente en interés del Estado para el mantenimiento del ordenamiento juridico, el establecimiento y conservación de la paz jurídica y la comprobación del derecho entre las partes. Éste es el fin de la institución procesal para el que ha sido creada por el Estado" (Leo Rosenberg, Tratado de derecho procesal civil, p. 3).

16. "El tribunal está obligado a administrar justicia y las partes tienen derecho a lo que puede denominarse pretensión a la administración de justicia o al otorgamiento de justicia o sencillamente pretensión a la justicia. Esta pretensión se dirige contra el Estado como organos estatales designados para administrar justicia, en especial los tribunales, a los cuales obliga a cumplirla frente a las partes" (idem, ibidem, p. 11).

17. Idem, ibidem, p. 11-12.

18. "Pero la Idea fundamental del concepto de Wach fue ulteriormente atacada com violencia por Bülow y Kohler. Bülow objeto que no puede exigirse una sentencia favorable antes y fuera del proceso; sólo al final y de éste y no antes es cuando consta si el demandante tiene derecho a una sentencia favorable" (James Goldschmidt, op. cit., p. 28).

19. "El proceso es una relación de derechos y obligaciones recíprocos, es decir, una relación jurídica" (Oskar Von Bülow, La teoria de las excepciones procesales y presupuestos procesales).

20. Carlos Alberto Alvaro de Oliveira, Efetividade e tutela jurisdicional, Revista Forense, vol. 101, n. 378, p. 113-133. 
essa obrigação deriva da obrigação que o Estado tem de administrar a justiça. ${ }^{21} \mathrm{O}$ direito processual seria somente o lado formal da relação entre Estado e indivíduo, e o direito justicial material seria o direito material dirigido ao próprio Estado. ${ }^{22}$

Nesse sentido, novamente de acordo Alvaro de Oliveira:

O direito justicial material compreende a totalidade das normas relativas à pretensão de tutela dirigida contra do Estado. Além disso, determina o conteúdo da sentença, por meio de normas imperativas dirigidas ao juiz, revelando-se para a pretensão à tutela jurídica como "o direito subjetivo do direito justicial civil material". Assim, a pretensão à tutela jurídica e o direito privado material, pensado em sua direção contra o Estado, pertencem ao mesmo campo e, sob esse ponto de vista, são quase idênticos. ${ }^{23}$

Para esse autor, o direito à tutela pertence ao direito material, apesar de ter natureza processual, afastando-se, portanto, do pensamento desenvolvido por Wach e do conceito clássico de actio romana; ele conclui que "el proceso es el procedimiento cuyo fin es la constitución de la cosa juzgada, es decir, del efecto de que la pretensión del actor valga en el porvenir ante los tribunales como jurídicamente fundada o no fundada". ${ }^{24}$

No Brasil, Pontes de Miranda, ainda influenciado pelas ideias da doutrina do direito de ação abstrato de Wach, afirmou que o direito material e o processo não se confundem, porém, "a ação é instituto do direito material, e não do direito formal ou processual [...] a pretensão é o poder de exigir alguma prestação". ${ }^{25}$ De acordo com ele, a ação não é dirigida contra o Estado, mas contra o indivíduo que praticou a lesão; também entende que o direito à tutela não se confunde com o direito à decisão

21. James Goldschmidt, op. cit., p. 20.

22. "[...] que el concepto de la exigencia de la protección jurídica no es de indole procesal, aun siendo pública. Pertenece, más bien, al ámbito del derecho justicial material. Este no es otra cosa sino el derecho privado considerado y completado desde un punto de vista juridico público. Detrás de cada precepto del derecho privado se encuentra su proyección en el derecho justicial material. Detrás de casi todos los derechos subjetivos privados se encuentran las acciones correspondientes: por ej., el art. 1.445 del código civil español dispone que por el contrato de compraventa el comprador se obliga a pagar por la cosa comprada un precio cierto. Detrás de este precepto del derecho civil se encuentra el precepto del derecho justicial material en virtud del cual cuando el comprador no cumpre su obligación, el Estado tiene, frente ao vendedor, el deber de constreñir al comprador a pagar el precio" (idem, ibidem, p. 29).

23. Carlos Alberto Alvaro de Oliveira, Efetividade e tutela jurisdicional, Revista Forense, vol. 101, n. 378, p. 113-133.

24. James Goldschmidt, op. cit., p. 38. O autor, mais adiante, é bem claro ao asseverar que o processo deve buscar a sua finalidade empírica que se traduz na solução do conflito, e essa solução somente tem força vinculativa com a coisa julgada.

25. Francisco Cavalcanti Pontes de Miranda, Tratado da ação rescisória das sentenças e de outras decisões, p. 11. 
favorável, aproximando-se aí do pensamento de Bulöw. ${ }^{26}$ Na mesma linha de Bülow, Pontes de Miranda entende que não há pretensão se o processo não for instaurado ela passa a existir somente com a propositura da ação - e afirma que se a pretensão existe antes do processo é porque ela está relacionada aos institutos de direito material e não processual. ${ }^{27}$ Da análise do pensamento de Pontes de Miranda, conclui-se que a teoria se aproxima mais dos elementos do direito material do que dos elementos de direito processual. ${ }^{28} \mathrm{O}$ autor finaliza seu estudo defendendo que a finalidade do processo é realizar o direito objetivo. ${ }^{29}$

No mesmo sentido é o pensamento de Ovídio Araújo Baptista da Silva, que diferencia os conceitos de ação de direito material e de ação processual. O primeiro é contra quem praticou a lesão, enquanto o segundo é dirigido contra o Estado, para que este exerça a atividade jurisdicional, prestando assim a tutela buscada. ${ }^{30}$

Vale ainda destacar o pensamento de Couture, ao descrever que o conceito de ação mudou muito durante a história e identificar três significados principais: como sinônimo de direito; como sinônimo de demanda; como a faculdade de provocar a atividade do poder jurisdicional. É o último significado que o autor explora, afinal, em

26. "Não há aí direito a sentença favorável. Existem direito e pretensão à sentença, que se presume justa, porque os Estados ou os árbitros prometem justiça. Implícita em tal promessa está a de ser favorável a que tenha razão" (idem, ibidem, p. 16).

27. Idem, ibidem, p. 17.

28. “Como se vê, homem de seu tempo, preso às suas raízes culturais e à doutrina alemã, Pontes de Miranda, retoma o conceito de pretensão de Windscheid, de certa forma semelhante ao de Savigny, e lhe empresta a denominação de ação de direito material. Adiciona ao esquema a ação abstrata, tal como esboçada por Müther, e como já o fizera o próprio Windscheid. Nesse quadro, totalmente concretista, proclamou, contudo, na linha de Plósz e de Degenkolb, que o autor não teria direito a uma sentença favorável, mas apenas a uma sentença de conteúdo, que se presume justa. Por isso mesmo, não consegue se desvencilhar da expressão cunhada por Wach, embora empregue o conceito de pretensão à tutela jurídica, em sentido totalmente diverso, como antes ressaltado. Demais, disso, embora não confesse, faz o conceito de ação de direito material desempenhar o mesmo papel do direito justicial material de Goldschmidt. Este, recorde-se não só colocava a acionabilidade do direito na norma jurídica material, como também conceituava o direito justicial material como direito material privado orientado contra o Estado" (Carlos Alberto Alvaro de Oliveira, Efetividade e tutela jurisdicional, Revista Forense, vol. 101, n. 378, p. 113-133).

29. Francisco Cavalcanti Pontes de Miranda, op. cit., p. 56. Mais adiante, o autor conclui: "Existe, pois, direito público subjetivo a que o Estado, por seus órgãos, preste justiça. É o direito à prestação jurisdicional. Ou melhor: a pretensão à tutela jurídica, de que é espécie a pretensão à resolução judicial. O sujeito ativo é aquele que vai a juízo; o sujeito passivo é o Estado, ou, por ele seus órgãos" (idem, ibidem, p. 58).

30. "O conceito de ação processual assenta-se na premissa de existir, como um plus lógico, um direito público subjetivo que a precede, por meio do qual o Estado reconhece e outorga a seus jurisdicionados o poder de invocar a proteção jurisdicional. Não se pode, portanto, confundir as duas categorias. Uma coisa será o direito subjetivo processual, por meio do qual a ordem jurídica reconhece a alguém o poder de tornar efetivo o direito através do exercício da 'ação' processual. Outra, não o poder, mas o exercício efetivo desse direito, por meio da 'ação"” (Ovídio Araújo Baptista da Silva, Curso de processo civil). 
sua obra. ${ }^{31}$ Couture separa o direito público do direito material, e para isso inclui um novo sujeito na relação processual: o Estado, o qual usará de seu poder para forçar o devedor a pagar ao credor. Para o autor, é essa a diferença entre o direito obrigacional e a ação. ${ }^{32} \mathrm{O}$ conteúdo da pretensão não é da natureza de direito processual, mas sim pertence ao direito material. A ação é um direito constitucional assegurado a todos os cidadãos.

Feita essa análise histórica, cumpre verificar qual o atual sentido de tutela jurisdicional. Nota-se que todo o conceito desenvolvido até aqui está muito ligado ao direito material e, muitas vezes, ignora o papel do Estado na prestação da tutela jurisdicional.

Conforme Liebman, o processo é o meio para realização do direito material, mas somente se alcança tal escopo através da ingerência do Estado que aplica o direito material: 33 "L'azione é dunque um diritto al mezzo, non al fine, e cio in due sensi diversi, quello del suo contenuto e quello della sua direzione, che sono poi due aspetti di un'unica relazione". ${ }^{34}$ Ou seja, o processo é um direito ao meio e não ao fim. ${ }^{35}$

31. Eduardo J. Couture, Fundamentos del derecho procesal civil.

32. "El objeto de la obligación es la satisfacción de las expectativas legitimas del acreedor, mediante el cumplimiento por parte del obligado. Cuando el derecho subjetivo funciona normalmente, las distintas situaciones del acreedor y del deudor hallan satisfacción: el deudor cumple la obligación y libera su patrimonio de esa carga que lo gravaba: el acreedor ve satisfecho su derecho y transforma en bien jurídico lo que era una expectativa legítima. La circulación de los bienes entre obligados y acreedores se produce dentro del orden regular del derecho. Pero si el obligado no cumple, la acción tiende a asegurar los bienes que son la expectativa del acreedor, por todos los otros medios de que dispone el Estado. Esos medios son, normalmente, la ejecución forzada o el cumplimiento por un tercero (a cargo del deudor) de las obligaciones a que estaba sujeto el deudor. A esta diferencia de objeto, se suma la diferencia de los sujetos entre los cuales funciona la acción y la obligación. En tanto que en la obligación los sujetos son el acreedor y el deudor, en la acción hay un nuevo cuya función es dominante y necesaria: Estado" (idem, ibidem, p. 21).

33. "Si vedar alora che ese non é afato uno atramento inanimado che l'interessato possa maneggiare a sua piacimento; perché tutt'al contrario esso risulta dall'attività combinata di alcuni uomini, tra i quali è essenziali la figura del giudice, persona e non cosa, soggetto e nonoggetto, organo di una funzione sovrana che sisvolge nel processo secondo le sue regole e se sue esigenze. L'essenza dell'azione si trova proprio nel rapporto che corre nell'ordinamento giuridico tra l'iniziativa del singolo e l'esercizio, in concreto, della giurisdizione, vale a dire nella necessità e nell'efficacia dell'invocazione del giudice perché proceda; e appartiene all'essenza del processo che il giudice debba determinare, secondo le norme che regolano la sua attività, il contenuto positivo o negativo del suo provvedimento finale" (Enrico Tullio Liebman, Problemi del processo civile, p. 30-31).

34. Idem, ibidem, p. 30-31.

35. "A confusão entre ação de direito material e direito subjetivo decorre, sem dúvida, de um erro de perspectiva que ignora a relação de meio a fim entre os dois direitos. A ação serve para a tutela do direito material, mas não se confunde com o direito que se pretende seja atendido em juízo. A concepção privatística do processo, da mesma maneira que levou o sistema a gravitar inteiramente sobre o direito subjetivo, induziu também à crença de que este não era outra coisa senão o direito exercido em juízo. Pouco a pouco, porém, por meio de uma série de tentativas, alcançou-se a separação: cumprindo esclarecer que uma coisa é o direito exercido em juízo (id est correspondente 
Atualmente, não há dúvida de que direito material e o processo estão separados, e que o direito de ação é um direito fundamental de acesso à justiça. Assim, o Estado é o único revestido do imperium para determinar e executar, e, por isso mesmo, não há influência do direito material, somente de normas de direito público e constitucionais.

Conforme demonstrado, a teoria do direito de ação abstrata vai contra o conceito de sumarização do processo e de outras formas especiais. Isso porque, se a ação fosse o único meio de fazer valer a pretensão jurisdicional, não haveria por que existir outros meios processuais: existiria um único meio que abrangeria todo o processo de conhecimento.

Com novas necessidades surgidas no presente pelo amplo acesso ao Poder Judiciário e, sobretudo, pela necessidade de sumarização, volta-se a estudar e dar o devido crédito a esse tipo processual que foi deixado de lado por tanto tempo, bem como a novos instrumentos que possam concretizar o direito de forma célere e sumária.

\subsection{Conceito}

Realizada essa introdução acerca do conceito de tutela jurisdicional, cumpre agora analisar o seu conceito mais moderno, sob a óptica do direito de ação assegurado constitucionalmente, e a inafastabilidade do Poder Judiciário. ${ }^{36} \mathrm{O}$ ponto de partida para análise do conceito de tutela jurisdicional é a constatação de que toda pessoa, por mais que viva em uma sociedade primitiva, é titular de direitos. Para fazer valer esses direitos assegurados às pessoas, o sistema judiciário, por mais simples que seja, o faz sempre por meio de um instrumento: o processo. ${ }^{37}$ Nesse contexto, o que seria a tutela jurisdicional?

Primeiramente, pode-se entender a tutela jurisdicional como acesso ao Poder Judiciário para defesa de direitos e interesses, assegurando-se as garantias mínimas de um sistema, esse acesso é permitido a todos aqueles que tiveram um direito ameaçado

à pretensão) e outra o direito de obter de o ofício proveja sobre a pretensão, e dessa forma se separaram por sua vez o direito subjetivo material e o direito subjetivo processual" (Carlos Alberto Alvaro de Oliveira, Efetividade e tutela jurisdicional, Revista Forense, vol. 101, n. 378, p. 113133).

36. A tutela jurisdicional não é apenas o acesso ao Judiciário, mas também a sua verdadeira apreciação pelo Judiciário. Cf. Flávio Luiz Yarshell. Tutela jurisdicional, p. 16.

37. Cf. Jorge Carrión Lugo, La tutela jurisdiccional efectiva, Revista de Derecho y Ciencia Política, vol. 59, p. 311-344. 
ou lesado. Desse modo, todos podem requerer a tutela jurisdicional ao Estado, mesmo que não consigam o resultado prático procurado, uma vez que o que é garantido constitucionalmente é o processo - o meio para se alcançar a tutela jurisdicional. ${ }^{38}$

Esse direito de acesso ao Poder Judiciário é uma cláusula pétrea, prevista na Constituição, assim como o devido processo legal e a ampla defesa, envolvendo a garantia do juiz natural, o direito de defesa e a adequação das formalidades do procedimento. ${ }^{39}$ No art. $5^{\circ}$, os incisos XXXV, ${ }^{40} \mathrm{LIV}^{41}$ e $\mathrm{LV}^{42}$ são claros ao disporem sobre os princípios que asseguram a tutela jurisdicional, quais sejam: 1) inafastabilidade do Poder Judiciário; 2) devido processo legal; 3) contraditório; 4) ampla defesa.

Mas será a tutela jurisdicional o direito ao acesso ao Poder Judiciário? O direito a se submeter a esse poder e simplesmente aguardar uma decisão? Entendemos que não. Não basta garantir o simples acesso ao Poder Judiciário sem dar o mínimo de garantia ao jurisdicionado. Não se defende aqui que a tutela jurisdicional signifique, necessariamente, o direito a uma sentença de mérito, mesmo porque o direito, a razão, será decidida após o exercício do contraditório, a verificação do direito, a realização das provas e, por fim, com a prolação da sentença, oportunidade na qual o Juiz analisará se o direito material buscado é devido ou não. Defendemos, portanto, outro conceito de tutela jurisdicional, o qual não se restrinja ao simples acesso ao Poder Judiciário, mas proceda à prestação efetiva do bem da vida buscado pelo jurisdicionado. $^{43}$

Por muitos anos, a imagem do processo civil como ciência, principalmente por juristas de outras áreas, foi a de apenas estabelecer métodos e formas preestabelecidas

38. Cf. José Roberto dos Santos Bedaque, Tutela cautelar e tutela antecipada: tutelas sumárias e de urgência (tentativa de sistematização), p. 65.

39. Cf. Humberto Theodoro Júnior, A garantia fundamental do devido processo legal e o exercício do poder de cautela, Revista dos Tribunais, ano 80, vol. 655, p. 11-22.

40. "XXXV - A lei não excluirá da apreciação do Poder Judiciário lesão ou ameaça a direito".

41. "LIV - Ninguém será privado da liberdade ou de seus bens sem o devido processo legal".

42. "LV - Aos litigantes, em processo judicial ou administrativo, e aos acusados em geral são assegurados o contraditório e ampla defesa, com os meios e recursos a ela inerentes".

43. Conforme Comoglio: "In senso stretto, azione è (non soltanto la possibilità, ma) l'accesso effettivo alle corti ed ai tribunali, ossia il potere, dell'attore di promuovere il procedimento civile, proponendo una domanda giudiziale nei confronti di chi debba essere citato e convenuto dinanzi al giudice. In senso più lato, azione è anche, per chi proponga la domanda, il diritto di essere 'ascoltato' dal giudice ed il potere di agire nel corso del giudizio, allegando i fatti rilevanti, producendo o faceto assumere le prove, trattando e discutendo la causa, affinché il giudice possa pronunziarsi sul merito di quella domanda, dichiarandola fondata oppure no" (Luigi Paolo Comoglio, Garanzie costituzionali e "giusto processo" (modelli a confronto), Revista de Processo, n. 90 , p. 111. 
para que as partes pudessem litigar, como se fosse apenas um preenchimento de um formulário necessário para ter acesso ao Poder Judiciário. No entanto, da metade do século XX em diante mostrou-se que o processo civil não é o preenchimento de um formulário e o estabelecimento de regras pré-moldadas, mas um pensamento estratégico e uma forma de outorgar justiça aos cidadãos, garantindo às partes seus direitos.

A tutela jurisdicional apenas é totalmente outorgada quando o provimento estatal garantir os meios executivos necessários para a completa satisfação da decisão outorgada. Não basta a outorga da sentença, com seu trânsito em julgado; é necessária a efetividade da sentença com a garantia da execução.

Ainda, em outros capítulos da Constituição Federal encontram-se artigos legais que são importantes para a efetivação da tutela jurisdicional; entre eles, os que tratam da organização do Judiciário e do dever de motivação das decisões judiciais. Não se trata apenas de um direito de primeira categoria em que o Estado não interfere, mas, pelo contrário, o Estado deve ser organizado o bastante para poder proporcionar uma tutela efetiva e de qualidade aos seus jurisdicionados.

Aqui, como fez Comoglio, ${ }^{44}$ é importante considerar o aspecto político em que o processo está inserido. Não há dúvida de que o processo é um instrumento político do Estado, mas será o momento de repensarmos qual a influência desse instrumento? Ele ajuda no controle do Estado, serve como meio para legislar, julga questões importantes que podem definir a vida política do país? Quando pensamos de maneira abstrata em tutela jurisdicional devemos pensar no efeito político disso também e com isso qual esse novo conceito nessa nova sociedade. Certamente, é essencial analisar o sistema constitucional em que está inserido o processo para somente então chegar a uma conclusão do conceito de tutela jurisdicional. Desse modo, qualquer cidadão que ajuíze uma ação já possui o direito à uma tutela jurisdicional, seja ela de procedência ou improcedência. Não é a garantia do resultado do processo, mas a garantia da intervenção estatal para se resolver o conflito. ${ }^{45}$

Em 1996, Dinamarco já atentava ao estudo da tutela jurisdicional e procurou renovar o conceito, que até então tinha apenas uma perspectiva estática e formalista. No artigo "Tutela jurisdicional”, o professor já asseverava que

\footnotetext{
44. Luigi Paolo Comoglio, op. cit., p. 95 e ss.; I modelli di garanzia costituzionale del processo, Rivista Trimestrale di Diritto e Procedura Civile, vol. 3, p. 673.

45. Cf. Rogério Aguiar Munhoz Soares, Tutela jurisdicional diferenciada, p. 96.
} 
[...] tutela jurisdicional não é o mero exercício da jurisdição, ou somente a outorga do provimento jurisdicional em cumprimento ao dever estatal que figura como contraposto do poder de ação. A ação em si considera-se satisfeita e exaurida sempre que emitido esse provimento, quer seja favorável ou desfavorável. É, portanto, um conceito indesejavelmente técnico, para quem busca resultados - e o processo civil de hoje é um processo civil de resultados. ${ }^{46}$

Ainda segundo Dinamarco, "tutela jurisdicional é o amparo que, por obra dos juízes, o Estado ministra a quem tem razão num processo". ${ }^{47}$ Não há dúvida de que a tutela jurisdicional vai além da possibilidade de se ajuizar uma ação, sendo necessário que o Estado outorgue tal tutela a quem de fato foi buscá-la. ${ }^{48}$ Nesse sentido, a tutela jurisdicional não reside necessariamente na sentença, mas nos efeitos que ela projeta para fora do processo, para a vida. ${ }^{49}$ Assim, a coisa julgada não basta, pois esta apenas estabiliza as relações; a efetividade e os efeitos dessa sentença são necessários além do processo. ${ }^{50}$

O processo civil atual é um processo de resultados: não basta a prolação da sentença, se ela não se efetiva, se ela não é eficaz, se não consegue entregar o bem da vida à parte. É necessário enfatizar a efetividade do processo, sem se esquecer jamais, obviamente, da segurança jurídica. Ovídio Araújo Baptista da Silva é claro ao estabelecer que a função da tutela jurisdicional não se limita a declarar a sentença, encerrando o processo, mas também realizar o direito material que não pode mais ser resolvido pela via privada, pelo monopólio estatal da justiça e a proibição da autotutela. $^{51}$ A tutela jurisdicional pode ser entendida ainda como "aquela que

46. Cândido Rangel Dinamarco, Tutela jurisdicional, Revista de Processo, ano 21, n. 81, p. 54. No mesmo sentido, Bedaque afirma: “O grande desafio do operador do processo está centrado no problema maior da efetividade e na necessidade de se desenvolverem mecanismos aptos a alcançar esse objetivo" (José Roberto dos Santos Bedaque, op. cit., p. 68).

47. Cândido Rangel Dinamarco, Tutela jurisdicional, Revista de Processo, ano 21, n. 81, p. 61.

48. "O processo como instrumento de realização do direito material e dos valores sociais mais importantes, deve proporcionar esse resultado com rapidez, sob pena de tornar-se inútil” (José Roberto dos Santos Bedaque, op. cit., p. 75).

49. Segundo Yarshell, tutela jurisdicional "se presta a designar o resultado da atividade jurisdicional - assim considerados os efeitos substanciais (jurídicos e práticos que o provimento final projeta ou produz sobre dada relação - em favor do vencedor. Nessa medida é inegável que a locução tutela jurisdicional designa em favor de quem tem razão (e assim exclusivamente), isto é, em favor de quem está respaldado no plano material do ordenamento" (Flávio Luiz Yarshell, Tutela jurisdicional, p. 24).

50. Quem advoga conhece muito bem essa realidade. Muitas vezes se consegue uma sentença de mérito, mas que não é exequível, pois o devedor não possui bens para satisfazê-la.

51. “A verdadeira essência da função jurisdicional não é, portanto, o pronunciamento da sentença que compõe o litígio - que não passa de uma atividade-meio, apenas instrumental - senão que 
proporciona ao titular do direito substancial possibilidade de usufruir dos efeitos a ele assegurados no plano jurídico-material". ${ }^{52}$ Desse modo, está intrinsecamente ligada ao conceito de eficiência do processo. Ou seja, a tutela jurisdicional somente atende aos anseios se for eficiente. O tempo de duração do processo é essencial, não pode o autor (ou réu) ser onerado pela demora do Poder Judiciário, e o tempo corre em desfavor daquele que tem razão. ${ }^{53}$

Ou seja, a referida garantia do mero acesso ao Poder Judiciário é essencial, pois apenas se todos tiverem acesso irrestrito o processo poderá ocorrer. Some-se a isso a independência dos juízes. É necessário escrever uma nova história brasileira, na qual os juízes decidam de forma imparcial, mas ativa, e possuem outra educação, não tão formalista, aproximando-se da realidade brasileira e despindo-se de preconceitos para, ao final, outorgar a tutela jurisdicional o mais próxima da justa possível, pois atuar no Poder Judiciário, seja como funcionário, advogado, juiz, promotor é, acima de tudo, uma tarefa política. ${ }^{54}$

Não se resumindo à prolação da sentença e, em última instância, aos atos executivos, o direito à tutela jurisdicional provê a garantia do contraditório, a participação no processo de forma idônea em procedimento adequado. Assim é resguardado o direito de participação no processo, pois, se não for assegurada a participação adequada no processo, a própria outorga da tutela jurisdicional poderá ser comprometida. Nesse contexto, cabe fazer uma pequena diferenciação entre tutela jurisdicional e tutela de direitos. ${ }^{55}$ A tutela de direitos existe independentemente do

corresponde à realização do direito material que o Estado impediu que se fizesse pela via privada da autorrealização" (Ovídio Araújo Baptista da Silva, op. cit., p. 86).

52. Cf. José Roberto dos Santos Bedaque, op. cit.

53. O conceito de eficiência no direito varia para cada autor, para Dinamarco, eficiência significa atingir os escopos jurídico, político e social cumprindo a pacificação social (cf. Cândido Rangel Dinamarco, A instrumentalidade do processo). Já para Marcelo Lima Guerra, eficiente significa menor diferenciação entre a tutela outorgada pelo Estado e a tutela obtida caso a parte não recorresse ao sistema jurídico (cf. Marcelo Lima Guerra, Estudos sobre o processo cautelar). Bedaque fala ainda em efetividade do processo, como uma garantia constitucional (cf. José Roberto dos Santos Bedaque, op. cit., p. 75).

54. Esse é o pensamento de Boaventura de Sousa Santos, que, ao analisar a Justiça brasileira, entende que ela precisa passar por uma revolução democrática. Cf. Boaventura de Sousa Santos, Para uma revolução democrática da justiça.

55. Conforme ensina Bedaque a tutela de direitos existe independentemente do acesso ao Judiciário. E algumas vezes as pessoas que se dirigem ao Judiciário não necessariamente são titulares de direito, mas, independentemente dessa condição de titular de direito essas mesmas pessoas são titulares da tutela jurisdicional, todos têm acesso ao Judiciário. "Mas nem todos os que se dirigem ao Poder Judiciário são titulares de direitos. Muitos afirmam essa condição, mas não conseguem demonstrá-la, levando o juiz a rejeitar a pretensão apresentada. Mesmo esses, todavia, têm direito ao mecanismo estatal de solução de controvérsias. Basta a afirmação de um direito, lesado ou 
processo, está situada no "plano substancial do ordenamento", enquanto a tutela jurisdicional só ocorre quando há intervenção jurisdicional. ${ }^{56}$

Essa diferenciação entre tutela jurisdicional e tutela de direito é essencial para o entendimento da divisão teórica do conceito de tutela jurisdicional. De acordo com ela, fica claro que tanto o autor quanto o réu recebem a tutela jurisdicional, ainda que de maneiras distintas: a tutela outorgada ao autor é justamente o bem da vida que ele foi buscar perante o Judiciário, caso seja acolhida a sua pretensão; para o réu, caso seja negada a pretensão do autor, é a segurança jurídica proporcionada por uma sentença transitada em julgado. ${ }^{57}$

Por fim, ainda que se admita em menor grau, pode-se falar em tutela jurisdicional do vencido, uma vez que o processo tenha chegado ao fim e se encerre a discussão controvertida, circunstância em que ela se torna mais evidente, pois durante o processo as duas partes são iguais e têm acesso à mesma tutela. Por isso mesmo o processo deve garantir o direito ao contraditório, pois apenas assim as partes têm acesso à ordem jurídica justa ao exporem suas razões. É necessário manter todos os mecanismos de garantia do processo. ${ }^{58}$

Para Rogério Munhoz, embora exista tanto para o autor quanto para o réu, a tutela jurisdicional ocorre de forma distinta, sendo plena: para o autor, quando lhe é dado um provimento favorável; para o réu, quando lhe são garantidos o contraditório e as demais garantias processuais constitucionais. ${ }^{59}$ Tal opinião merece respeito, mas não concordamos com ela. Tutela jurisdicional não significa garantir o resultado do processo - principalmente para o autor, o que significaria voltar às raízes do odioso processo do autor. Significa antes garantir o acesso e um julgamento eficaz e justo,

ameaçado, para que a pessoa tenha acesso à jurisdição e ao processo”. Cf. José Roberto dos Santos Bedaque, op. cit., p. 65.

56. “[...] a tutela de direitos é fenômeno situado originariamente no plano substancial do ordenamento. Pode ela ocorrer dentro ou fora do processo, isto é, mediante intervenção estatal - pelo exercício da jurisdição - ou não. Daí falar-se nessa segunda hipótese, em tutela jurisdicional dos direitos, isto é, a tutela de direitos mediante o exercício da jurisdição" (Flávio Luiz Yarshell, Tutela jurisdicional, p. 25).

57. "O Estado também presta tutela jurisdicional ao vencido, embora de forma diversa daquela prestada ao vencedor. Isso é ainda reforçado quando se pensa, mais uma vez, no resultado do processo; se não sob o enfoque de seu escopo jurídico, certamente sob o enfoque de seu escopo social, cuja expressão mais importante é a pacificação pela eliminação da controvérsia" (Flávio Luiz Yarshell, Tutela jurisdicional, p. 32).

58. "O processo deve significar para as pessoas o mecanismo apto a proporcionar-lhes esse acesso, isto é, deve ser dotado de garantias suficientes para que as partes possam deduzir suas razões, bem como para que o real titular do direito o veja reconhecido e satisfeito de forma efetiva e eficaz". Cf. José Roberto dos Santos Bedaque, op. cit., p. 78.

59. Cf. Rogério Aguiar Munhoz Soares, op. cit., p. 123. 
não importando ser o resultado favorável ao autor ou ao réu. As garantias constitucionais estão atreladas ao processo e, sem respeitar essas garantias, o processo é nulo e a tutela jurisdicional não foi prestada, quando deveria ser, ao réu e também ao autor. Concordamos, assim, com a afirmação de que também existe tutela jurisdicional para o réu: quando se rejeita o pedido do autor, se reconhece que este não tem direito ao que já pleiteou, garantindo ao réu que a questão não poderá ser discutida no Judiciário novamente. ${ }^{60}$

Essa renovação do conceito de tutela jurisdicional vai ao encontro das necessidades de uma nova sociedade. Uma sociedade de consumo, com mihões de titulares de direitos que têm acesso ao Poder Judiciário. Assim, com a mudança de necessidades, o processo civil também teve de se adequar por meio de várias reformas legislativas a fim de acelerá-lo. As mudanças, realizadas através das chamadas “ondas renovatórias", tiveram consequências para o conceito de tutela jurisdicional - a última delas, especificamente, concentrou-se no acesso à justiça. ${ }^{61} \mathrm{E}$ essas reformas legislativas não ocorreram apenas no Brasil, mas em diversos países a legislação tem sido reformada para que o processo seja mais célere e atenda os anseios da população.

Detenhamo-nos ao caso italiano, apenas mencionado anteriormente. Na Itália, país que influencia enormemente o sistema processual brasileiro, a primeira grande reforma ${ }^{62}$ ocorreu no processo cautelar sobre a não necessidade do periculum in mora e de um juízo de cognição plena em processos cautelares, pois muitas vezes a tutela cautelar já era satisfativa, não necessitando de um processo posterior de cognição plena uma vez que o deferimento da cautelar entregava totalmente a tutela jurisdicional. ${ }^{63}$ Assim, começou um movimento para a não obrigatoriedade da propositura da ação principal, surgindo o art. 23 do Decreto Legislativo n. 5, de janeiro de 2003, que prevê

60. Carlos Alberto Garbi, Tutela jurisdicional diferenciada e efetividade do processo, Revista dos Tribunais, ano 89, vol. 782, p. 50 .

61. Cf. Ricardo de Barros Leonel, Eficácia imediata das sentenças e as reformas do CPC: um aspecto da caminhada para a efetividade da tutela jurisdicional, Revista Magister de Direito Civil e Processual Civil, ano 1, n. 3, p. 18-39.

62. Existiram outras reformas também, principalmente no processo societário italiano, com forte tendência do référé provision francês. Contudo, as críticas a tais mudanças foram tantas que o instituto foi revogado.

63. ' $[\ldots]$ la revisione della disciplina dei provvedimenti d'urgenza con l'esclusione dell'onere per la parte istante di promuovere la causa di merito; tutto cio sul presupposto che la misura cautelar espresso può rappresentare per la parte la soddisfazione integrale per l'attuazione del diritto leso, talché il giudizio di merito si risolverebbe in uno sterile giudizio di conerma della misura cautelare" (Massimo Fabiani, Il rito cautelare societario (contraddizioni e dubbi irrisolti), Rivista di Diritto Processuale, ano LX [seconda serie], n. 4, p. 1184). 
a não aplicação do art. 669, octies, do Codice di Procedura Civile, referente à não obrigatoriedade do início do juízo de mérito.

Tornando-se a tutela cautelar independente da tutela principal, a decisão proferida em sede cautelar não perdia a eficácia se não proposta ação principal, pois em muitas situações era evidente a completa inutilidade da propositura da ação principal, o que causava apenas mais demora ao jurisdicionado e gasto ao Estado. Ainda, se a ação principal for proposta e julgada extinta, a decisão proferida em sede cautelar se mantém.

$\mathrm{Na}$ maioria das vezes, a tutela cautelar deferida era substancialmente igual à decisão proferida em sede de cognição plena, embora fosse formalmente diferente haja vista ser provisória -, enquanto a proferida no processo principal era definitiva. O legislador, com o escopo de resolver a crise na Justiça italiana, introduziu essa norma prevista no Decreto Legislativo n. 5, autorizado pela norma n. 366, em que ficou advertida a exigência de se definir rapidamente as questões relativas à deliberação de assembleia, aprovação do balanço da sociedade, exclusão de sócios etc., para evitar que a demora na prestação jurisdicional acarretasse um prejuízo para a sociedade empresarial. ${ }^{64}$ Essa inovação proposta pelo legislador fez tanto sucesso entre os italianos que foi mantida na reforma processual de 2005, com a inclusão do comma $6^{\circ}$ no art. 669 do Código de Processo Civil italiano, no qual permaneceram os efeitos do provimento cautelar, no caso de extinção do processo principal sem julgamento de mérito.

No Brasil, também as reformas foram (e são) diversas, tanto que está sendo discutida a elaboração de um novo CPC. Assim, um processo efetivo "é aquele dotado de mecanismos adequados à proteção das situações de direito substancial deduzidas perante o juiz, assegurando a satisfação aos interesses jurídicos que tais relações

64. Giorgio Constantino cita alguns exemplos de aplicação do processo societário cautelar: "In base all'ido quod plerumque accidit, la tutela cautelare invocabile in materia societaria, consiste nella sospensione delle deliberazioni impugnate, per le quali dovrebbe funzionare il giudizio abbreviato di cui all'art. 24 , comm $4^{\circ}$, nel sequestro conservativo in funzione delle azioni di risarcimento nei confronti dei responsabili della gestione sociale, nel sequestro giudiziario delle partecipazioni nell controversie sulla titolarità e sul possesso delle medesime; i provvedimenti cautelari di revoca e sostituzione degli amministratori sono solitamente chiesti nell'ambito dei procedimenti per la denuncia delle gravi irregolarità ai sensi dell'art. 2.409 c.c. e quindi nelle forme del procedimento camerale in confronto di più parti, ai sensi dell'art. 30 d.lgs. 17 gennaio 2003, 5" (Giorgio Constantino, Il nuove processo commerciale: la tutela cautelare, Rivista di Diritto Processuale, ano LVIII [seconda serie], n. 3, p. 657). 
regulam". ${ }^{65}$ Ou seja, não basta assegurar o acesso ao Poder Judiciário, mas para que a tutela jurisdicional seja efetiva devem-se assegurar todas as condições e meios adequados para atingir a satisfação dessa tutela jurisdicional. E isso inclui, obviamente, assegurar meios de defesa do réu.

A seguir, serão discutidos os diversos tipos de tutela cuja característica comum é a sumariedade, com vistas a acelerar o processo.

\subsection{Tutela jurisdicional diferenciada}

O processo de cognição plena, por sua definição garantista, tem uma duração necessária que não se coaduna com a litigiosidade crescente da sociedade atual. Por isso fala-se em uma tendência da sumarização da cognição para atender a todos os anseios sociais de forma célere, justa e eficaz. ${ }^{66}$ Por um lado, essa litigiosidade tem um aspecto bom, já que significa que as massas estão cientes de seus direitos e procuram o Poder Judiciário para efetivá-los. Por outro, a quantidade de pessoas que procuram o Judiciário é enorme, e o Estado não consegue resolver todos os problemas

65. Cf. José Roberto dos Santos Bedaque, op. cit., p. 82.

66. Cf. Eduardo Righi, Tutelas de urgência e efetividade do processo, Revista Forense, vol. 105, n. 401, p. 151-186. Ovídio Araújo Baptista da Silva faz severas críticas à ordinarização do procedimento e a escolha deste como o procedimento comum: "Chiovenda dizia, no começo do século - imaginem os senhores a gravidade desta afirmação - que as ações sumárias eram incompatíveis com a civilização moderna, que a coisa mais importante que o homem havia descoberto era o procedimento ordinário. Há uma curiosa e mal encoberta ideologia neste enaltecimento das virtudes do procedimento ordinário, aqui faz com que o poder formal e informal que o canta em prosa e verso, dele não se valha. O procedimento ordinário é bom para a plebe, porque o Estado quando necessita valer-se da tutela jurisdicional, cria para si próprio instrumentos especiais, em geral drástica e severamente sumários. As esferas de poder que gravitam em torno do poder formal, igualmente não se utilizam do procedimento ordinário, a começar pelo comércio e indústria que têm seus títulos de crédito que fazem com que seus titulares transponham o procedimento ordinário, indo diretamente ao processo de execução. O Estado, quando quer desapropriar, cria uma lei absurdamente sumária, onde a defesa é praticamente impossível. O BNH tem (ou tinha) igualmente uma lei, provavelmente inconstitucional, tal a severidade da limitação da defesa. Os bancos e as instituições financeiras também têm suas leis. E todo mundo continua dizendo que a grande descoberta do século é o procedimento ordinário. De modo que, já que o legislador não nos deixa outra alternativa, por onde se possa atingir aquilo a que inicialmente me referi, que é efetividade e a plena realização do direito, particularmente nos casos em que aurgência de uma resposta jurisdicional se torne imperiosa, o exclusivo alvitre que nos resta, àqueles que têm o dever profissional de tratar o direito, não como o teórico que constrói seus castelos conceituais, mas como o prático que tem de resolver problemas existenciais, é valer-nos da única via que ainda nos resta, fazendo do processo cautelar a tábua de salvação para tudo o que carece de proteção jurisdicional urgente" (Ovídio Araújo Baptista da Silva, Teoria da ação cautelar, in: Da sentença liminar à nulidade da sentença, p. 71). 
que lhe são apresentados, tornando-se ineficiente e levando à descrença da população nas instituições judiciárias. É preciso alcançar o equilíbrio entre uma prestação jurisdicional de qualidade, com decisões fundamentadas, e célere, sem expor o jurisdicionado a uma situação de prejuízo pela demora do tempo do processo.

Conforme Proto Pisani, o século XX ficará conhecido pela doutrina processualista por tornar residual o processo de cognição plena. ${ }^{67}$ Não se ignora a conquista para 0 campo processual do processo de cognição plena, o qual passou a garantir maiores direitos ao réu, deixando para a história aquele processo do autor. O processo de conhecimento é com certeza uma conquista da democracia, que permite a plena participação das partes. ${ }^{68}$ Contudo, é preciso ter em mente que nem todas as hipóteses necessitam ter uma cognição aprofundada ou mesmo um processo com fases tão demarcadas e longas para que haja uma entrega jurisdicional justa que respeite o devido processo legal. De acordo com Ricardo Leonel, ${ }^{69}$ o termo “diferenciada" já traz à tona a ideia de uma tutela que não é ordinária ou comum. Apesar dessa facilidade de compreensão, o termo sem dúvida é equívoco e pode originar confusões. Donaldo Armelin $^{70}$ sugere dois posicionamentos para caracterizar esse tipo de tutela: a tipicidade do procedimento e a sumarização da cognição. Essa diferenciação também

67. "È poi considerare che il processo a cognizione piena, proprio in quanto per sua definizione garantista, ha una sua durata necessaria nel tempo e questa esigenza di fare bene può entrare talvolta in conflitto con l'esigenza di fare presto, specie là dove la durata del processo a cognizione piena possa essere di per sé causa di un pregiudizio irreparabile (o anche soltanto grave) a chi è costretto a servirsi del processo a causa del divieto di autotutela privata. E' mia convinzione che il ventesimo secolo passerà alla storia come il periodo in cui la legislazione e la dottrina processualistica hanno messo a punto tutta uma serie di congegni (spesso di origine antichissima, risalente al diritto comune del medio evo) diretti a rendere residuale il processo a cognizione piena nel sistema della tutela giurisdizionale dei diritti complessivamente intesa" (Andrea Proto Pisani, Verso la residualità del processo a cognizione piena?, Revista de Processo, ano 31, vol. 131, p. 239-249).

68. Nesse sentido, também entendende Carlos Alberto Alvaro de Oliveira: "Nem por assim entender menosprezo, no entanto, as garantias próprias do processo de conhecimento, tanto na forma ordinária quanto na sumária, o qual não considerado um mal em si, mas uma conquista da humanidade, principalmente depois de despido das inúteis e inúmeras formalidades do direito comum, assim como a democracia, notadamente depois dos sucessos do leste europeu, demonstrou ter ultrapassado a fronteira meramente ideológica, consagrando-se como real valor a ser preservado. A esse respeito, assoma-me perigosa a minimização sistemática do procedimento ordinário, pois pode conduzir ao desprezo total do próprio processo de conhecimento. E, queirase ou não, ainda com todas as suas imperfeições, a função processual de conhecimento continua sendo o remédio por excelência para a declaração definitiva dos direitos, com a certeza daí decorrente, também ela um valor não desprezível" (Carlos Alberto Alvaro de Oliveira, Efetividade e processo cautelar, Revista de Processo, ano 19, n. 76, p. 88-93).

69. Cf. Ricardo de Barros Leonel, Tutela jurisdicional diferenciada.

70. Cf. Donaldo Armelin, Tutela jurisdicional diferenciada, Revista de Processo, n. 65, p. 45-55. 
é seguida por José Roberto dos Santos Bedaque, ${ }^{71}$ ao indicar que esses processos dispensam a cognição plena e exauriente.

Para Leonel: "a tutela jurisdicional diferenciada deve ser compreendida como a proteção jurídica e prática outorgada pelo Estado-juiz, resultante da utilização de procedimentos especiais previstos no ordenamento processual, em que a celeridade e a efetividade da prestação jurisdicional decorram da limitação da cognição". ${ }^{72}$ Dessa definição, retiramos algumas características da tutela diferenciada as quais trataremos em seguida: tipicidade dos procedimentos; sumarização da cognição; celeridade; efetividade do provimento. Assim, podemos caracterizar a tutela diferenciada como aquela de cognição sumária.

Retomando o plano constitucional, verificamos que são assegurados diversos direitos, especialmente os direitos à efetividade processual e à segurança jurídica. Ambos, assegurados constitucionalmente, parecem se chocar à primeira vista, já que quanto mais tempo levar um processo (geralmente de cognição aprofundada) mais seguro ele deve ser, pois o juiz tem a oportunidade de se debruçar sobre todos os pontos da questão; ao mesmo tempo, porém, mais inefetivo esse processo é à medida que a tutela jurisdicional não for entregue de forma célere. ${ }^{73}$ A tensão existe porque tanto a segurança jurídica quanto a efetividade do processo podem ser agrupadas, genericamente, sob o manto do devido processo legal. Desse modo, por serem direitos constitucionais, de idêntica raiz, sem haver hierarquia entre eles, a solução do conflito torna-se mais difícil. É necessário buscar uma solução harmonizadora, que equilibre os dois princípios em colisão e os conserve, ainda que de modo relativizado. ${ }^{74}$ Uma

71. Cf. José Roberto dos Santos Bedaque, op. cit.

72. Ricardo de Barros Leonel, op. cit., p. 25. Continua o autor: "Com efeito, quando a doutrina fala, por exemplo, de uma tutela jurisdicional diferenciada, não cogita apenas do resultado substancial a ser proporcionado ao titular de uma posição jurídica de vantagem, mas também dos meios predispostos à consecução desse resultado. Assim, embora nesse contexto o resultado se revista de peculiaridades e características ditadas pelos meios ordenados a sua consecução, é também para esses últimos que se atribui o qualificativo diferenciado" (idem, ibidem).

73. No mesmo sentido, Teori Albino Zavascki afirma: "O decurso do tempo, todos sabem, é inevitável para a garantia plena do direito à segurança jurídica, mas é, muitas vezes, incompatível com a efetividade da jurisdição, notadamente quando o risco de perecimento do direito reclama tutela urgente. Sempre que se tiver presente situação dessa natureza - em que o direito à segurança jurídica não puder conviver, harmônica e simultaneamente, com o cireito à efetividade da jurisdição - ter-se-á caracterizada hipótese de colisão de direitos fundamentais dos litigantes, a reclamar solução harmonizadora" (Teori Albino Zavascki, Medidas cautelares e medidas antecipatórias: técnicas diferentes, função constitucional semelhante, Revista de Processo, vol. 21, n. 82, p. 53-69).

74. Conforme Giuseppe Tarzia: “[...] il conflito, che definerei brutale, del nostro tempo tra l'esigenza di efficienza e quela di garanzia, non si può comporre, evidentemente, con l'eliminazione della 
das maneiras de equilibrar a segurança jurídica com a efetividade é através das medidas de caráter provisório e, muitas vezes, de cognição sumária. Aí que se encaixa o conceito de tutela diferenciada.

Em algumas situações específicas, foram descritas na lei a medida a ser adotada, por exemplo, nas cautelares típicas. Contudo, como é sabido, não é possível ao legislador prever todas as hipóteses da vida na lei. Por isso mesmo, o legislador autoriza em algumas hipóteses a utilização pelo juiz do poder geral de cautela, previsto no art. 798 do CPC - o art. 273, que trata sobre a tutela antecipada, pode ser considerado igualmente um poder geral de cautela. Apesar de os requisitos para a concessão de uma e de outra sejam diversas, eles ainda são abrangentes o suficiente para abarcar diversas situações da vida. Pela leitura desses dois dispositivos legais fica claro que eles descrevem situações de possível colisão entre efetividade e segurança jurídica, abrindo a oportunidade para que o próprio juiz chegue à solução mais adequada ao caso concreto.

Nesse sentido, é interessante o posicionamento de Teori Zavascki sobre o tema: para ele, a possibilidade de serem decretadas medidas provisórias, sejam cautelares ou antecipatórias (mas sempre urgentes), demonstra o poder que o juiz tem para solucionar conflitos entre direitos fundamentais de dois princípios que formam têm como base o devido processo legal. ${ }^{75} \mathrm{E}$ isso somente é possível se considerado o nosso sistema constitucional, inequívoco ao estabelecer que o juiz sempre deve decidir e ao lhe conceder certa liberdade.

A utilização da tutela de cognição sumária nos ordenamentos jurídicos não é uma exclusividade brasileira. Na Itália, por exemplo, a sumarização da cognição já ocorre como uma maneira de evitar os custos do processo de cognição plena e entregar a

giustizia ordinaria o della giustizia sommaria, ma con il contemperamente di quelle due esigenze, all'interno del sistema stesso della giurisdizione provvisoria" (Giuseppe Tarzia, Considerazioni comparative sulle misure provvisorie nel processo civile, Rivista di Diritto Processuale, n. 2, p. 252).

75. Nesse sentido entende Teori Albino Zavascki: "O que sustentamos, em suma, é que o poder jurisdicional de decretar medidas provisórias cautelares ou antecipatórias, representa, simplesmente, o poder de formular regras de solução para os fenômenos concretos de conflito entre direitos fundamentais que formam o devido processo legal. Trata-se de poder que nasce, não propriamente do art. $5^{\circ}$, inciso XXXV, da Constituição, como tutela preventiva,mas do sistema constitucional organicamente considerado: configurados, como inevitavelmente se configuram na realidade prática, fenômenos de colisão entre segurança jurídica e efetividade da jurisdição, tornarse-á inafastável a necessidade de formular solução harmonizadora, tarefa que, na omissão da lei, deve, por imposição do sistema constitucional, ser assumida necessariamente pelo juiz" (Teori Albino Zavascki, Medidas cautelares e medidas antecipatórias: técnicas diferentes, função constitucional semelhante, Revista de Processo, vol. 21, n. 82, p. 53-69). 
tutela da forma mais eficiente possível aos juridicionados, além de ser utilizada ara evitar o abuso do direito de defesa (condanna con riserva di eccezioni). Igualmente, no Brasil a tutela de cognição sumária é utilizada para acelerar o processo e entregar a tutela em tempo adequado.

Diante do exposto, a conclusão só pode ser a de que a tutela diferenciada tem como característica fundamental a sumariedade na cognição, cuja diferenciação está baseada tanto na urgência do direito pleiteado quanto na evidência. ${ }^{76}$ Passaremos a analisar as diversas espécies da tutela diferenciada, dividas em três grandes grupos: 1) tutela de urgência; 2) tutela não urgente; 3) outros procedimentos.

\subsubsection{Tutela de urgência}

Diferenciada pelo critério temporal, uma vez que a urgência no perecimento do direito obriga o juiz a proferir uma decisão liminar para assegurar a utilidade do resultado, é um tipo de tutela polêmica, tal como tratada pela doutrina, ${ }^{77}$ pois implica a mitigação de garantias processuais. Em um primeiro momento, o juiz tem conhecimento somente de parte dos fatos, com base na qual deverá decidir, sem dar oportunidade ao contraditório. Essa é a primeira sumariedade. Há ainda a sumariedade no julgamento final, especialmente no procedimento cautelar, uma vez que a atividade cognitiva do julgador não será profunda, ainda que tenha sido realizado o contraditório, e com base nessa cognição superficial ele dará o resultado do julgamento. ${ }^{78}$ Mas, principalmente, trata-se de tutela que somente é deferida em razão do periculum in mora. ${ }^{79}$

76. José Roberto dos Santos Bedaque, op. cit., p. 364.

77. Esse é o entendimento de Barbosa Moreira e de Leonardo Grecco. Para esses processualistas, é impensável admitir a tutela de urgência, uma vez que somente com a cognição exauriente é possível entregar a tutela jurisdicional completa. Cf. Leonardo Grecco, Cognição sumária e coisa julgada, in: IX Jornadas de Direito Processual, p. 7; José Carlos Barbosa Moreira, Miradas sobre o processo civil contemporâneo, in: , Temas de direito processual, p. 49-50.

78. Kazuo Watanabe, Da cognição no processo civil.

79. Comoglio, Ferri e Taruffo ensinam que o procedimento cautelar surgiu como uma resposta a "lentezza del procedimento ordinario", em que muitas situações era necessário conservar a situação ou antecipar a tutela evitando assim, o seu perecimento. "Alla inevitabile lentezza del procedimento ordiario si contrappone, così, l'esigenza di celerità di um adeguato sistema di mezzi cautelari, in cui la provvisorietà e la strumentalità di determinate misure, da adottarsi d'urgenza, consentano principalmente al giudice: - per un verso, di 'conservare' lo stato di fatto e di diritto esistente, ovvero lo status quo ante della res litigiosa, allo scopo di salvaguardare 11adempimento di una prestazione, 11 esercizio delle ragioni di credito vantate da chi invoca la tutela, l'effetività dell accertamento giurisdizionale o l'efficacia delle future azioni esecutive sul patrimonio del debitore; - per altro verso, di 'anticipare' tempestivamente taluni effetti del provvedimento di merito, al fine di assicurarne a priorila definitiva fruttuosità pratica, ch dal ritardo potrebbe essere 
Amplamente utilizada e abrangente, a tutela de urgência é gênero do qual são espécies a tutela cautelar e a tutela antecipada: cada qual tem seus requisitos específicos, que serão analisados em seguida, mas conservam em comum a urgência no pleito, ${ }^{80}$ a fim de afastar o risco da infruttuosità ${ }^{81}$ dando a tutela jurisdicional às partes para evitar que o seu direito pereça. As duas espécias, a cautelar e a antecipada, acabam se confundindo. É o caso clássico da "cautelar de sustação de protesto", que nada mais é que uma cautelar inominada cujos efeitos são os mesmos de uma antecipação da tutela em um processo ordinário.

Relembremos que a tutela de urgência está claramente ligada à efetividade da tutela jurisdicional. ${ }^{82} \mathrm{Ou}$ seja, é uma tutela provisória e instrumental: provisória porque somente conservará seus efeitos até a prolação da tutela jurisdicional definitiva; instrumental porque tem como objetivo assegurar a efetividade da tutela jurisdicional definitiva.

altrimenti frustrata in modo irreparabile" (Luigi Paolo Comoglio; Corrado Ferri; Michele Taruffo, Lezioni sul processo civile).

80. Nesse sentido entende Ricardo de Barros Leonel: "Com o devido respeito àqueles que professam entendimento diverso, parece-nos correta essa solução, na medida em que o tratamento uniforme ou homogêneo para as medidas conservativas e satisfativas decorre do reconhecimento de que elas são espécies de um mesmo gênero, apresentando-se em perspectiva funcional, com o mesmo papel: afastar a situação de perigo seja tratando-se de pericolo da infruttuosità (no caso das conservativas) ou de pericolo de tardivittà (no caso das antecipatórias ou satisfativas), nos termos da lição de Calamandre, já citada. Em outras palavras, se cautelares e antecipações servem à mesma função, consistente em evitar que a demora do processo torne a dano de quem tem razão, seu tratamento deve ser homogêneo" (Ricardo de Barros Leonel, Tutela jurisdicional diferenciada no projeto de novo Código de Processo Civil).

81. Cf. Piero Calamandrei, Introduzione allo studio sistematico dei provvedimenti cautelari.

82. Especificamente sobre o conceito de tutela de urgência e sua abrangência, Ferrucio Tommaseo explica como ela está umbilicalmente ligada à efetividade da tutela jurisdicional: "Invero, la constatazione della vasta latitudine di poteri che le norme sui provvedimenti d'urgenza sembrano attribuire al giudice e la consapevolezza che la lettera della norma di per sé non esclude un possibile contenuto anticipatorio della tutela urgente, hanno cospirato a incoraggiare la lettura in chiave funzionale dell'istituto disciplinato negli artt. 700 ss. CPC. Tendenza vie più favorita, sul piano teorico, dall'esistenza nel processo civile di un principio di effettività della tutela giurisdizionale secondo il quale l'interpretazione delle norme deve essere rivolta soprattutto a trarre dalle stesse strumenti per quanto possibile idonei a realizzare tale principio" (Ferruccio Tommaseo, I provvedimenti d'urgenza. Struttura e limiti della tutela anticipatoria, p. 55). 


\subsubsection{Tutela cautelar ${ }^{83}$}

Conforme José Roberto dos Santos Bedaque, "tutela cautelar é providência requerida antes ou no curso do processo de cognição ordinária, destinada a neutralizar perigos que possam comprometer a efetividade (ou a fruttuosità) do resultado final, em razão do tempo necessário para alcançá-lo". ${ }^{84}$ A partir desse conceito, podem-se extrair as características principais da tutela cautelar: sumariedade; instrumentalidade; provisoriedade; ${ }^{85}$ urgência.

A sumariedade decorre da cognição restrita do juiz, que deve se debruçar sobre o processo com as informações ali trazidas, geralmente por só uma das partes, sem adentrar profundamente nas questões. ${ }^{86} \mathrm{~A}$ instrumentalidade da tutela cautelar advém da necessidade de ser proposta uma nova ação, geralmente ordinária, em que serão analisadas de forma profunda as questões postas, geralmente por ambas as partes. ${ }^{87} \mathrm{~A}$ provisoriedade está intrinsecamente ligada à instrumentalidade, por ser a tutela cautelar uma tutela instrumental (que é dependente de uma ação ordinária) e provisória, somente surtindo seus efeitos até a prolação da decisão no procedimento

83. Ao longo deste trabalho, vamos sempre utilizar o termo tutela cautelar conforme Calamandrei, "per analoghe considerazioni, mi par che, come oggetto della nostra ricerca, la nozione di 'provvedimento cautelare' debba esser preferita a quella di 'azione cautelare': non solo perché, se l'azione è concepita come il potere di provocare un atto giurisdizionaele che può servire a definire i vari tipi di azione, e non viceversa; ma anche perché, se si hanno casi (e un tipico ne troveremo proprio nel corso di questo studio) nei quali esiste un provvedimento a cui non corrisponde un'azione (giurisdizione senza azione), questi non potrebbero trovare adeguata collocazione sistematica in una classificazione che si limitasse a inquadrare in vari tipi di provveimento giurisdizionali nella cornice dei vari tipi di azioni " (Piero Calamandrei, Introduzione allo studio sistematico dei provvedimenti cautelari, p. 5).

84. José Roberto dos Santos Bedaque, op. cit., p. 36.

85. Segundo Calamandrei, a provisoriedade é a principal característica das tutelas cautelares, isso porque há uma "limitazione della durata degli effetti" (Piero Calamandrei, op. cit., p. 9).

86. "Questi elementi inducono a ritenere che il carattere di cognizione urgente postulata dalla normativa commentata si discosti dalle caratteristiche tipiche della sommarietà. Si tratterebbe cioè di un procedimento che si svolge sì con forme urgenti, ma che si fonda su una fattispecie giuridica tendenzialmente predefinita nei suoi elemti controversi" (Lotario Dittrichi, Dalla tutela cautelare anticipatoria alla tutela sommaria definitiva, Rivista di Diritto Processuale, ano XLIII, n. 3, p. 672-705).

87. 'L' altro requisito (la strumentalità) pone, a sua volta, in evidenza che la misura cautelare non è autonoma, ma si subordina (in un rapporto strumentale tra mezzo e fine) all'instaurazione o alla definizione del procedimento di cognizione piena sul merito della controversia. Essa nasce (per così dire) al servizio del provvedimento decisorio definitivo ed è funzionalmente preordinata alla sua successiva pronuncia, nonché alla preventiva salvaguardia della sua futura utilità o fruttuosità pratica, operando perlopiù in queste tre forme principali" (Luigi Paolo Comoglio; Corrado Ferri; Michele Taruffo, op. cit., p. 369). 
ordinário. ${ }^{88}$ Por fim, a urgência é uma característica essencial da tutela cautelar, que implica medidas que não podem aguardar o julgamento final da ação, ao contrário o direito pode perecer. $^{89}$

A tutela cautelar, tanto no direito brasileiro quanto em sistemas estrangeiros, surgiu como uma medida típica, prevendo algumas situações específicas, com requisitos próprios. É o caso do sequestro, arresto, caução, busca e apreensão e outros procedimentos específicos. Contudo, o art. $798^{90}$ do CPC prevê o denominado poder geral de cautela e deixa a critério do juiz a possibilidade de outorgar a tutela cautelar desde que comprovados os requisitos específicos, quais sejam: periculum in mora ${ }^{91} \mathrm{e}$ fumus boni iuris. Assim, a regra seria apenas utilizar os procedimentos cautelares específicos, com requisitos próprios para a outorga da tutela jurisdicional cautelar. No entanto, a realidade dos fatos comprovou uma vez mais que é impossível ao legislador prever todas as situações da vida, e tornou-se muito frequente utilizar o art. 798 do CPC para fundamentar grande parte dos pedidos cautelares. A possibilidade de uma cautelar atípica, protegendo situações de perigo não previstas nos procedimentos específicos, é mais um passo para a entrega de uma tutela efetiva e de um processo instrumental, a favor do direito material, não apenas um fim em si. ${ }^{92}$

88. "La provvisorietà dei provvedimenti cautelari sarebbe dunque un aspetto ed una conseguenza di un rapporto che passa tra gli effetti del provvedimento susseguente (definitivo), l'inizio dei quali segnerebbe la cessazione degli effetti del primo" (Piero Calamandrei, op. cit., p. 11).

89. "La natura sussidiaria del procedimento ex art. 700 si riflette anche sulle condizioni di ammissibilità del ricorso: a differenza degli altri procedimenti cautelari la cautela urgente è ammissibile solo laddove il periculum in mora che minaccia il diritto sia non solo imminente, ma anche potenzialmente idoneo a provocare un pregiudizio irreparabile. È questo un requisito che limita ulteriormente l'utilizzazione dell'istituto ai casi in cui nessun'altro rimedio sarebbe utilmente esperibile" (Lotario Dittrichi, Presuposti e limiti, in: Giuseppe Tarzia (org.), I procedimenti cautelari a cura di, p. 166).

90. “Art. 798. Além dos procedimentos cautelares específicos, que este Código regula no Capítulo II deste Livro, poderá o juiz determinar as medidas provisórias que julgar adequadas, quando houver fundado receio de que uma parte, antes do julgamento da lide, cause ao direito da outra lesão grave e de difícil reparação".

91. Ovídio Araújo Baptista da Silva critica esses requisitos do periculum in mora, pois a ideia de perigo da demora está atrelada à mora do inadimplemento e isso seria uma antecipação do mérito, que nada mais é que a satisfação. Para referido autor gaúcho a cautelar não pode jamais ter caráter satisfativo. Citando Pontes de Miranda, ele afirma que há uma diferença entre a "segurança de uma execução", que é o conceito puro de cautelar, e "execução para segurança", que nada mais é do que satisfação e não possui caráter cautelar. Cf. Ovídio Araújo Baptista da Silva, op. cit., p. 67.

92. A esse respeito, ver a posiçao de Giuseppe Tarzia sobre a importância das cautelares atípicas: "Não creio que se deva constitucionalizar o procedimento das cautelares atípicas, pois isso tornaria bem difícil qualquer modificação legislativa das normas processuais pelo menos nos países de constituição rígida, como é o caso da Itália. Todavia o seu caráter geral, de proteção de qualquer direito, torna a medida cautelar atípica instrumento para a realização do princípio da igualdade. Por outro lado, a sua idoneidade para remediar a lentidão do processo ordinário a coloca como um meio para garantir a efetividade do direito de ação e da tutela jurisdicional" (Giuseppe Tarzia, 
A priori servem somente para assegurar o resultado útil do processo, sem, propriamente, antecipar os efeitos da decisão. ${ }^{93}$ É um meio de o juiz minimizar o tempo, que em algumas situações poderá prejudicar a satisfação da tutela jurisdicional buscada no Poder Judiciário. ${ }^{94}$

A tutela cautelar pretende diminuir o fator tempo em duas situações. Na primeira, para evitar que tempo necessário para o desenvolvimento do processo dificulte a execução da sentença, atuando, inclusive, para evitar esse tipo de dano, por exemplo, nas cautelares típicas de sequestro e arresto, e garantir o cumprimento da futura execução. Esse caso está ligado mais a cautelar conservativa, antecipando determinados efeitos da tutela. Na segunda situação, para evitar que o tempo seja fator

Medidas cautelares atípicas, Revista da Pós-Graduação da Faculdade de Direito da Universidade de São Paulo, vol. 4, p. 118).

93. Adroaldo Furtado Fabrício faz uma interessante análise sobre a cautelar, que merece ser transcrita: "Uma terceira possibilidade é a da formação de processo cautelar, onde não se busca nem o acertamento do direito, nem a realização prática de um direito que já é certo, mas a tutela da segurança como um valor em si mesma. O ofício judicial é invocado para prover no sentido de garantir que o resultado útil de um processo (de conhecimento ou de execução; em andamento ou a instaurar-se) seja assegurado contra os riscos decorrentes da demora na sua ultimação ou das alterações que se possam introduzir, maliciosamente ou não, no estado de fato sobre o qual a futura prestação jurisdicional deverá influir. [...] O juiz também aí parte de uma situação de incerteza quanto ao cabimento, ou não do provimento acautelador, devendo aquilatar da sua necessidade $\mathrm{e}$ conveniência; para esse efeito, necessariamente terá de lançar os olhos sobre a 'lide principal', mas não para decidir dela, sim, e somente para verificar, em termos de probabilidade, se há mesmo o que acautelar (fumus boni iuris). De outra banda, terá de avaliar se o resultado prático esperado do processo principal corre efetivamente algum risco relacionado ao correspondente tempo de tramitação (periculum in mora). Não é difícil perceber que também aí se desenvolve típica atividade judicial de conhecimento, mas com a particularidade de voltar-se ela para esses aspectos particulares da plausibilidade da pretensão principal e do perito na demora. A cognição exercida quanto à lide principal é imprescindível, mas superficial e não exauriente, já que o juízo a emitirse será de probabilidade e não de certeza" (Adroaldo Furtado Fabrício, Breves notas sobre provimentos antecipatórios, cautelares e liminares, Revista da Ajuris, vol. 66, p. 10).

94. Essa característica de assegurar o resultado útil do processo também é vista em procedimentos cautelares estrangeiros nos quais o jurisdicionado pode utilizar a tutela cautelar para resguardar uma situação ou evitar que algum mal lhe aconteça, impedindo o resultado final da sentença de mérito: "La c. d. azione cautelare - che, nella tradizione, si configura come una mera azione, svincolata dal diritto cautelato, o come un'azione assicurativa concessa al cittadino quando ancor non si sa se quel diritto esista - esprime il bisogno attuale ed effettivo di rimuovere da quel diritto il timore di un incombente danno giuridico. Essa esprime il diritto di chiedere - e, laddove ne suscitan i presupposti, il diritto di ottenere - una determinata forma di tutela (vale a dire: la tutela cautelare, provvisoria e urgente, con effetti anticipatori o conservativi). Essa, quindi, si esercita con il compimento di un tipico atto di iniziativa processuale, espressione specifica dell' agire in giudizio garantito dal $1^{\circ}$ comma dell'art. 24 Cost., propnendo una domanda nella qualle:

- da un lato, si afferma come verosimile e probabile l'esistenza del diritto cautelato, alla luce degli elementi di prova disponibili prima facie (è il c.d. fumus boni juris).

- dall'altro, si allega la presenza di fatti integrativi del pericolo imminente, grave e irreparabile, cui il ritardo nell'accertamento di quel diritto ptrebbe esporre la fruttuosità della sentenza di merito che interverrà tutelarlo (è il c.d. periculum in mora)" (Luigi Paolo Comoglio; Corrado Ferri; Michele Taruffo, op. cit., p. 366-367). 
de prejuízo, causando uma inutilidade do futuro provimento que, como será resultado de um processo de cognição plena, poderá demorar muito para ser proferido. Essa hipótese trata de uma cautelar que garantirá a efetividade da futura sentença de mérito.

Como será uma tutela provisória, pois a rigor a parte deverá pleitear a tutela definitiva, o juiz em sede de cogninção sumária analisará os elementos ali apresentados verificando se há possibilidade de resultado favorável ao requerente. Ou seja, é necessária uma análise, ainda que sumária, do direito material posto e verificar se em um juízo profundo de cognição o requerente teria a mesma sorte. ${ }^{95} \mathrm{O}$ ordenamento brasileiro é claro ao prescrever dois requisitos essenciais para a concessão da tutela: fumus boni iuris - a plausibilidade do direito invocado pelo requerente - e periculum in mora $^{96}$ - o fator de urgência necessário para a concessão da tutela sem o contraditório. ${ }^{97}$ Até por se tratar de tutela de urgência, o requisito do periculum in mora é essencial para a caracterização da medida cautelar. Isso porque deve existir um receio de frustração do direito caso a tutela não seja deferida. Por esse motivo a tutela cautelar exige uma cognição sumária, ou seja, com menor grau de certeza quanto à existência

95. Nesse sentido, Comoglio e Ferri defendem a provisoriedade como característica principal da tutela cautelar: "Pertanto, la caratteristica di struttura della stessa tutela cautelare è data dalla provvisorietà, nel senso che gli effetti del provvedimento sono destinati a durare solo entro determinati limiti temporali, mentre il provvedimento no è idoneo, dunque, a disciplinare in via definitiva il rapporto controverso" (Luigi Paolo Comoglio; Corrado Ferri, La tutela cautelare in Italia: profili sistematici e riscontro comparativi, Rivista de Diritto Processuale, vol. 45. n. 4, p. 963-901).

96. A existência do periulum in mora é requisito para outros ordenamentos jurídicos e para a concessão da tutela cautelar sem a oitiva da parte contrária. É o exemplo do sistema espanhol, em que o autor deve mostrar o real perigo de perecimento do direito caso não seja concedida a tutela: "In merito al periculum, la legge onera il richiedente della prova della concrete situazioni che potrebbero prodursi durante la pendenza del processo e che, pertanto, potrebbero impedire o rendere più difficile l'effettività della tutela giurisdizionale (art. 728, primo comma, prima parte. La formula utilizzata è ingrado di ricomprendere sia il cd. Pericolo da infruttuosità che il non si limita a definire in positivo tal requisito, ma individua nella sua seconda parte una specifica circostanza estintiva del periculum, circostanza che, in assenza di espressa disposizione legislativa, molto probabilmente avrebbe assunto rilevanza solo quale mero indizio dell'assenza di espressa disposizione legislativa, molto probabilmente avrebbe assunto rilevanza solo quale mero indizio dell'assenza di pericolo. Si tratta dell'ipotesi in cui la misura sia volta a modificare una certa situazione di fatto per lungo tempo (durante largo tiempo) secondata dal sollecitante; ricorrendo tale circostanza, la misura non può essere concessa, salvo che venga fornita congrua giustificazione circa le ragioni per le quali la misura cautelare non è stata richieta in precedenza" (Fabio Cossignani, Brevi note in tema di tutela cautelare nella ley de enjuiciamento civil, in: Antonio Carratta (org.), La tutela sommaria in Europa: studi).

97. Como ensina Ovídio Araújo Baptista da Silva, o conceito de periculum in mora não está ligado à demora na prestação jurisdicional, tempo natural do processo, mas, sim, à urgência da tutela pleiteada, o perigo demonstrado pela parte que pode levar à inefetividade do processo. Cf. Ovídio Araújo Baptista da Silva, A ação cautelar inominada no direito brasileiro, p. 216. 
do direito da parte, já que a urgência do quanto requerido em juízo autoriza o seu deferimento, mesmo que não exista uma plena certeza quanto ao direito pleiteado. ${ }^{98}$

A tutela cautelar ${ }^{99}$ está prevista no livro III, arts. 796-889 do CPC. No sistema pátrio há a previsão genérica do poder geral de cautela do julgador, que pode conferir as medidas provisórias quando houver fundado receio de perecimento do direito. ${ }^{100}$ Ainda no art. $796^{101}$ fica evidente o caráter instrumental da medida, ao prever que a tutela cautelar é sempre dependente da tutela ordinária. O art. $798^{102}$ prevê o denominado poder geral de cautela, que é uma possibilidade, outorgada pelo legislador, de conceder tutela cautelar mesmo nas situações não tipificadas no Código. Essa dependência prevista no CPC durante muito tempo acarretou um problema para os operadores do direito, pois muitas vezes a mera propositura da cautelar já era suficiente para resolver a crise de direito, já que se tratava de cautelar satisfativa, ${ }^{103}$ além de o art. $806^{104}$ combinado com o art. $808^{105}$ serem expressos ao asseverar que

98. Lotario Dittrichi, Dalla tutela cautelare anticipatoria alla tutela sommaria definitiva, Rivista di Diritto Processuale, ano XLIII, n. 3, p. 672-705.

99. Aqui cabe fazer um parêntese. Um dos livros mais utilizados neste trabalho foi Tutela cautelar $e$ tutela antecipada: tutelas sumárias e de urgência (tentativa de sistematização), de Bedaque, o qual tem um conceito de tutela cautelar um pouco diferente do restante da doutrina. Para ele, a tutela cautelar é admissível em qualquer procedimento, não necessariamente no capítulo específico do CPC reservado para tanto: "O estudo da cautelar deve ser feito a partir da ideia de tutela jurisdicional, sendo absolutamente irrelevante o aspecto de essa modadalidade de medida ser concedida mediante o exercício do direito ação, em processo autônomo, ou como decisão icidental no procedimento em curso. Ação cautelar, processo cautelar, medida cautelar incidente, são apenas mecanismos para obtenção da tutela cautelar. Importa, pois, descobrir a natureza dessa modalidade de proteção jurisdicional, que não se confunde com as demais formas de tutela: cognitiva e exeutiva ou satisfativa" (José Roberto dos Santos Bedaque, op. cit., p. 126). Compartilhamos de seu entendimento, embora tenhamos optado por tratar a tutela cautelar como prevista no CPC por uma questão metodológica. Este trabalho não pretende abordar a diferenciação entre tutela cautelar e tutela antecipada, mas, sim, a tutela diferenciada e sua estabilização.

100. "Art. 798. Além dos procedimentos cautelares específicos, que este Código regula no capítulo II deste livro, poderá o juiz determinar as medidas provisórias que julgar adequadas, quando houver fundado receio de que uma parte, antes do julgamento da lide, cause ao direito da outra lesão grave e de difícil reparação".

101. "Art. 796. O procedimento cautelar pode ser instaurado antes ou no curso do processo principal e deste é sempre dependente".

102. "Art. 798. Além dos procedimentos cautelares específicos, que este Código regula no capítulo ii deste livro, poderá o juiz determinar as medidas provisórias que julgar adequadas, quando houver fundado receio de que uma parte, antes do julgamento da lide, cause ao direito da outra lesão grave e de difícil reparação".

103. Como exemplo, a exibição de documentos. Muitas vezes, bastava para o autor apenas ter acesso aos autos para concluir que seria desnecessária a propositura de ação principal.

104. "Art. 806. Cabe à parte propor a ação, no prazo de 30 (trinta) dias, contados da data da efetivação da medida cautelar, quando esta for concedida em procedimento preparatório".

105. "Art. 808. Cessa a eficácia da medida cautelar: I - se a parte não intentar a ação no prazo estabelecido no art. 806; II - se não for executada dentro de 30 (trinta) dias; III - se o juiz declarar extinto o processo principal, com ou sem julgamento do mérito. Parágrafo único. Se por qualquer motivo cessar a medida, é defeso à parte repetir o pedido, salvo por novo fundamento". 
se não for proposta a ação principal no prazo de trinta dias cessará a eficácia da medida concedida. Esse cenário fomentou uma discussão sobre a desnecessidade da propositura da ação principal.

Na Itália, a discussão sobre a desnecessidade de um juízo de cognição plena em processos cautelares começou já nos anos 1990, sugerindo uma ampliação das hipóteses de tutela cautelar. Isso ocorreu pois em muitas situações a tutela cautelar já era satisfativa em si, prescindindo de um processo posterior de cognição plena, pois o deferimento da cautelar entregava totalmente a tutela jurisdicional. Conforme Massimo Fabiani:

[...] la revisione della disciplina dei provvedimenti d'urgenza con l'esclusione dell'onere per la parte istante di promuovere la causa di merito; tutto cio sul presupposto che la misura cautelar espresso può rappresentare per la parte la soddisfazione integrale per l'attuazione del diritto leso, talché il giudizio di merito si risolverebbe in uno sterile giudizio di conerma della misura cautelare. ${ }^{106}$

Assim, iniciou-se um movimento na Itália para a não obrigatoriedade da propositura da ação principal, do qual se originou o art. 23 do Decreto Legislativo $n$. 5, de janeiro de 2003, o qual prevê a não aplicação do art. 669, octies, do Código de Processo Civil italiano, da não obrigatoriedade do início do juízo de mérito. Daí é correto afirmar se trata de uma mitigação da instrumentalidade, pois não é obrigatória a propositura da ação principal, principalmente em casos de cautelares antecipatórias, e o provimento de mérito foi alcançado com o deferimento da tutela. $\mathrm{O}$ art. 23 do Decreto n. 5 possui as seguintes características: exclui a obrigação de se iniciar um juízo de mérito; exclui a possibilidade de que a extinção do juízo de mérito determine a ineficácia do provimento cautelar; impõe a liquidação da medida em caso de acolhimento; revoga parcialmente o art. 669, comma 10, do Código italiano e individua que o juízo que proferiu a decisão cautelar é o competente para revogá-la e modificar o provimento no caso de o juízo de mérito não ser instaurado; respeita a ineficácia do provimento cautelar consequente à ausência de cumprimento da caução ou a rejeição do mérito da demanda; e estabelece que em nenhum caso a autoridade do provimento cautelar é invocável em um processo diverso. ${ }^{107}$

\footnotetext{
106. Massimo Fabiani, Il rito cautelare societario (contraddizioni e dubbi irrisolti), Rivista di Diritto Processuale, ano LX (seconda serie), n. 4, p. 1184.

107. Essa característica será apreciada posteriormente, pois a decisão cautelar não tem força de coisa julgada, apenas se estabiliza, não sendo, portanto, invocável em outros processos.
} 
Ao tornar-se a tutela cautelar independente da tutela principal, a decisão proferida em sede cautelar não perde a eficácia se não proposta ação principal, pois em muitas situações era evidente a completa inutilidade da propositura da ação principal, o que causava apenas mais demora ao jurisdicionado e gasto ao Estado. Ainda, se a ação principal for proposta e esta for julgada extinta, a decisão proferida em sede cautelar se mantém. ${ }^{108}$

Ocorria na maior parte das vezes que a tutela cautelar deferida era substancialmente igual à decisão proferida em sede de cognição plena, contudo, era formalmente diferente, haja vista ser provisória, enquanto a proferida no processo principal era definitiva.

O legislador, com o escopo de resolver a crise na Justiça italiana, introduziu essa norma prevista no Decreto Legislativo n. 5, autorizado pela norma n. 366, a qual adverte a exigência de se definir rapidamente as questões relativas à deliberação de assembleia, aprovação do balanço da sociedade, exclusão de sócios etc., para evitar que a demora na prestação jurisdicional acarretasse um prejuízo para a sociedade empresarial $^{109}$

Essa inovação proposta pelo legislador fez tanto sucesso entre os italianos que foi mantida na reforma processual de 2005 com a inclusão do comma $6^{\circ}$ ao art. $669^{110}$ do Código italiano, em que foram mantidos os efeitos do provimento cautelar, no caso de

108. Cf. Elena Merlin, I limiti temporali di efficacia, in: Procedimenti cautelari a cura di Giusepe Tarzia.

109. Giorgio Constantino cita alguns exemplos de aplicação do processo societário cautelar: "In base all'ido quod plerumque accidit, la tutela cautelare invocabile in materia societaria, consiste nella sospensione delle deliberazioni impugnate, per le quali dovrebbe funzionare il giudizio abbreviato di cui all'art. 24 , comm $4^{\circ}$, nel sequestro conservativo in funzione delle azioni di risarcimento nei confronti dei responsabili della gestione sociale, nel sequestro giudiziario delle partecipazioni nell controversie sulla titolarità e sul possesso delle medesime; i provvedimenti cautelari di revoca e sostituzione degli amministratori sono solitamente chiesti nell'ambito dei procedimenti per la denuncia delle gravi irregolarità ai sensi dell'art. 2.409 c.c. e quindi nelle forme del procedimento camerale in confronto di più parti, ai sensi dell'art. 30 d.lgs. 17 gennaio 2003, 5" (Giorgio Constantino, Il nuove processo commerciale: la tutela cautelare, Rivista di Diritto Processuale, ano LVIII [seconda serie], n. 3, p. 657).

110. "Il giudice, sentite le parti, omessa ogni formalità non essenziale al contraddittorio, procede nel modo che ritiene piu' opportuno agli atti di istruzione indispensabili in relazione ai presupposti e ai fini del provvedimento richiesto, e provvede con ordinanza all'accoglimento o al rigetto della domanda.

Quando la convocazione della controparte potrebbe pregiudicare l'attuazione del provvedimento, provvede con decreto motivato assunte ove occorra sommarie informazioni. In tal caso fissa, con lo stesso decreto, l'udienza di comparizione delle parti davanti a se' entro un termine non superiore a quindici giorni assegnando all'istante un termine perentorio non superiore a otto giorni per la notificazione del ricorso e del decreto. A tale udienza il giudice, con ordinanza, conferma, modifica o revoca i provvedimenti emanati con decreto. Nel caso in cui la notificazione debba effettuarsi all'estero, i termini di cui al comma precedente sono triplicati”. 
extinção do processo principal sem julgamento de mérito. Foi o momento da expansão da mitigação da instrumentalidade aos procedimentos cautelares. ${ }^{111}$

Apesar da grande aceitação por parte da doutrina italiana, há alguns autores que criticaram as modificações feitas no instituto das cautelares, principalmente no que concerne à instrumentalidade. Afirma Massimo Fabiani: "Se l'intendimento del legislatore era piuttosto evidente, non si può fare a meno di evidenziare che la técnica normativa adoperata non há portato alla confezione di una disposizione nitida, tanto è vero che sono molteplici le questioni interpretative che fa sorgere". ${ }^{112}$ Esse autor faz críticas ao art. 23 do Decreto Legislativo n. 5.

Primeiro, critica o legislador não prever especificamente as hipóteses de cabimento dessa nova cautelar, o que traria insegurança ao jurisdicionado. Ousamos discordar dessa posição, pois a norma estava inserida dentro do processo societário italiano, ou seja, somente as matérias previstas no art. $1^{\circ}$ do Decreto Legislativo n. 5 poderiam ser objeto de tutela cautelar. Ademais, a referida norma serviu como "teste" para a futura reforma no processo cautelar em geral, prevista no Código de Processo Civil italiano. Com relação à instrumentalidade, reforçamos que há mitigação da instrumentalidade, e esta não foi totalmente excluída do sistema italiano, apenas deixou de ser obrigatória. Isso não é, necessariamente, um problema já que ficará a critério da parte sucumbente a propositura da ação principal, se esta não a propõe a decisão se estabiliza.

Ainda cabe ressaltar que, pela lógica, essa mitigação da instrumentalidade somente pode ocorrer nos casos de tutela cautelar satisfativa, pois apenas nessa situação houve entrega do bem da vida procurado pela parte. $\mathrm{O}$ mesmo não se pode dizer das tutelas cautelares conservativas, nas quais ainda é necessária a propositura de uma ação principal para declarar o mérito.

Fabiani critica a questão da estabilidade da tutela cautelar, diante da ausência de força de coisa julgada a tal decisão, pois

111. Para Andrea Graziosi, mais do que a mitigação da instrumentalidade, foi o momento de tornar a instrumentalidade eventual, porque cabe às partes optarem pela instauração do procedimento de cognição plena em momento posterior. Cf. Andrea Graziosi, La cognizione sommmaria del giudice civile nella prospettiva delle garanzie costituzionali, Rivista Trimestrale di Diritto $e$ Procedura Civile, vol. 63, n. 1, p. 163- 174.

112. Massimo Fabiani, Il rito cautelare societario (contraddizioni e dubbi irrisolti), Rivista di Diritto Processuale, ano LX (seconda serie), n. 4, p. 1181-1236. 
[...] nostro legislatore, non dà alcuna certezza e i rapporti sostanziali di diritto societario tanto hanno bisogno di una tutela celere quanto hanno bisogno di stabilità effettiva onde evitare che situazioni che paiono consolidate possano essere rimesse in discussione a distanza di tempo pari alla durata della prescrizione del diritto sostanziale. ${ }^{113}$

Ou seja, para o autor a mera estabilização da decisão não trará segurança aos jurisdicionados, já que a qualquer tempo poderá ser modificada a decisão. Com relação a essa premissa, demonstraremos adiante que a doutrina italiana não lidou bem com a inovação da estabilização da tutela sem a força da coisa julgada, tanto que as normas referentes ao processo societário foram revogadas. Aqui ainda resta uma pergunta: será que com todas essas modificações esta ainda seria uma tutela cautelar?

Roberta Tiscini esclarece bem essa questão ao afirmar que o fato de a tutela não ser mais instrumental e provisória não lhe retira a característica da cautelaridade, pois a principal peculiaridade da tutela cautelar é a urgência na concessão do provimento, o periculum in mora, a exigência de um provimento imediato para se evitar um dano irreparável ou de difícil reparação. Essa urgência não se confunde com a urgência necessária aos procedimentos de cognição sumária, que está ligada à ideia de celeridade e de economia processual. ${ }^{114}$ Apesar de todo o exposto, a instrumentalidade é uma característica importantíssima por estar ligada à provisoriedade do provimento. Ou seja, a tutela cautelar somente dura enquanto perdurar o instrumento processual cautelar, após isso, ela é substituída pela tutela definitiva.

A tutela cautelar tem finalidade de resguardar o provimento final buscado em juízo, evitando que o transcurso do tempo torne a tutela jurisdiciona inútil à parte. Por isso, muitas vezes definem a cautelar como instrumento do instrumento, já que ela serviria única e exclusivamente para tutelar situações de direito material que poderiam ser perdidas quando analisadas no julgamento da ação principal e de cognição plena e exauriente. Assim o objeto da cautelar seria resguardar o resultado da atuação jurisdicional do processo principal, e não, necessarimente, tutelar o direito material. ${ }^{115}$

No Brasil também existe tal discussão, conduzida principalmente por José Roberto dos Santos Bedaque em sua tese, que afirma que "a tutela cautelar pode implicar, pois, a antecipação de efeitos ligados ao provimento final. A segurança

113. Idem, ibidem.

114. Cf. Roberta Tiscini, I provvedimenti decisori senza accertamento.

115. Ferruccio Tommaseo, op. cit., p. 84. 
quanto ao resultado pode ser garantida não apenas por medidas conservativas, mas também antecipatórias. ${ }^{116 ",}$

Uma característica importante da tutela cautelar é sua provisoriedade. Isto é, o provimento cautelar persiste até ser proferida a decisão definitiva; assim que a tutela principal é deferida, cessam os efeitos da tutela cautelar. ${ }^{117,118}$ Mas, e no caso de não ser proferida? E se for desnecessária a tutela definitiva? ${ }^{119}$ Ora, não há dúvida de que a tutela cautelar se torne então definitiva.

Decorrente da provisoriedade da tutela cautelar, há a revogabilidade, pois, com a instrução processual, podem ficar provados outros fatos que afastam a tutela inicialmente deferida. A eficácia da tutela cautelar está na pendência da sentença do processo de mérito, quando ela pode ser revogada ou confirmada. Inerente ao provimento cautelar, há ainda a provisoriedade: o provimento é provisório até a

116. José Roberto dos Santos Bedaque, op. cit., p. 129.

117. Segundo Bedaque, essa não é a única característica da provisoriedade da tutela cautelar, mas também "reversibilidade dos efeitos causados pela tutela cautelar de conteúdo antecipatório" (idem, ibidem, p. 136). No mesmo sentido, acentuando o caráter provisório da tutela cautelar estão Comoglio, Ferri e Taruffo: "L’uno (la provvisorietà) sottolinea che gli effetti propri di un provvedimento cautelare sono interinali e temporanei, per loro stessa natura, non avendo istituzionalmente alcuna attitudine ad incidere in via definitiva sul rapporto controverso, come invece accade in atri sistemi processuali, ove talvolta certe misure cautelari possono eccezionalmente assurgere al rango di final remedies (si pensi ad es., negli ordinamenti di common law, ala final o alla perpetual injunction). Quegli effetti sono, quindi, destinati a prodursi soltanto per un determinato periodo cronologico, sino a quando non vengano caducati o assorbiti dal provvedimento di merito sul diritto cautelato" (Luigi Paolo Comoglio; Corrado Ferri; Michele Taruffo, op. cit., p. 368).

118. Ainda sobre a provisoriedade da tutela cautelar, é interessante ressaltar que a sua eficácia no tempo é provisória, limitada no tempo, em razão da sua curta duração. No entanto, a decisão é definitiva, apta a transitar em julgado, como é do entendimento de Fredie Didier Júnior, Paula Sarno Braga e Rafael Oliveira: "É, ainda, temporária, por ter sua eficácia limitada no tempo. Sua vida dura o tempo necessário para a preservação a que se propõe. Mas, cumprida sua função acautelatória, perde a eficácia. Tende a extinguir-se com a obtenção (ou não) da tutela satisifativa definitiva isto é, com a resolução da causa em que se discute e se efetiva o direito acautelado (ex.: satisfeito o direito de crédito, perde a eficácia a cautela de bloqueio de valores do devedor insolvente. Mas essa temporariedade não exclui sua definitividade. Já dissems e repetimos, a decisão cautelar cocnede uma tutela definitiva, dada com cognição exauriente de seu objeto (pedido de segurança, fundado no perigo da demora e na plausibilidade do direito acautelado) e apta a tornar-se imutável. Temporários são seus efeitos fáticos, práticos, afinal a cautela perde sua eficácia quando reconhecido e satisfeito o direito acautelado (ou quando esse não for reconhecido), mas a decisão que a concedeu, ainda ssim, permanece imutável, inalterável em seu dispositivo" (Fredie Didier Júnior; Paula Sarno Braga; Rafael Oliveira, Distinção entre tutela antecipada e tutela cautelar, in: Mirna Cianci et al. (orgs.), Temas atuais das tutelas diferenciadas: estudos em homenagem ao professor Donaldo Armelin).

119. Bedaque é claro ao afirmar que para ele a tutela cautelar é "aquela que não tiver aptidão para se transformar na solução definitiva do litígio" (José Roberto dos Santos Bedaque, op. cit., p. 142). $\mathrm{O}$ autor exclui as hipóteses em que a tutela tornou-se definitiva em razão da inércia das partes. Para ele, a provisoriedade é característica fundamental da tutela cautelar, chegando a afirmar que cautelar satisfativa em sede doutrinária não existe (idem, ibidem, p. 207). 
prolação da decisão definitiva, e os efeitos da decisão perduram no tempo até a prolação da decisão definitiva. ${ }^{120}$

A provisoriedade da decisão cautelar decorre de sua própria instrumentalidade, uma vez que ela depende da decisão final proferida, qual seja a sentença. Isso ocorre após um juízo de cognição plena e exauriente. Por ser uma decisão provisória, a tutela antecipada perde a sua eficácia quando da prolação da sentença. ${ }^{121}$ A urgência, característica essencial da tutela cautelar, não evita apenas o risco de demora do processo, mas de um acontecimento específico que vá imputar um fato grave ao requerente se não for deferido pelo Judiciário, ou por ele impedido de ocorrer. ${ }^{122}$

A relação com o direito material é muito próxima, tanto que muitas vezes a própria demonstração do fumus boni iuris se confunde com o mérito. Assim, resta a pergunta, qual a finalidade da tutela cautelar? Assegurar a efetividade da tutela jurisdicional final buscada pelo Requerente e isso pode ser alcançado através de seu caráter assecuratório ou mesmo com a antecipação dos efeitos da tutela. Dessa forma, é incorreta a afirmação de que a cautelar é o instrumento do instrumento, porque a cautelar não tem por objetivo única e exclusivamente para garantir o resultado útil do processo, mas também o direito material perseguido, já que em muitas situações o fumus boni iuris se confunde com o próprio mérito. Além do mais, considerando nosso sistema atual, que privilegia o direito material em detrimento do formalismo exacerbado do processo civil, a lógica de que o processo cautelar protege o direito material é mais condizente com a realidade constitucional-processual. ${ }^{123}$

120. Esse é o entendimento de Proto Pisani, ao afirmar: "Mentre il provvedimento cautelare - come si è visto - è sempre provvisorio, gli effetti del provvediento non lo sono sempre" (Andrea Proto Pisani, Le tutele giurisdizionali dei diritti: studi).

121. 'Il carattere cautelare di questi provvedimento volti ad attuare un'anticipazione satisfattiva della pretesa, veniva fondato - secondo l'insegnamento di Calamandrei - sul rilievo ritenuto determinante che essi non possono in nessun caso aspirare a diventare definitivi e ciò in quanto risultano preordinati, mediante un nesso di strumentalità, alla pronuncia del provvedimento principale. In altri termini, questo rapporto di strumentalità che colora in senso cautelare un'ampia serie di provvedimenti anticipatori si fonda, secondo la menzionata dottrina, sull'assorbente rilievo che essi sono preordinati alla emanazione della decisione principale, al sopraggiungere della quale sono destinati a perdere efficacia" (Ferruccio Tommaseo, I provvedimenti d'urgenza: struttura e limiti della tutela anticipatoria, p. 33).

122. Cf. José Roberto dos Santos Bedaque, op. cit., p. 134; Ferruccio Tommaseo, op. cit., p. 136-139.

123. Nesse sentido, eis o entendimento de Ovídio Araújo Baptista da Silva: “A tutela cautelar, portanto, protege o direito, e não o processo, como muito entendem [...] O pressuposto da existência, no caso concreto, de uma situação cautelanda acaba sendo o 'divisor de águas' entre a doutrina que tem as medidas cautelares destinadas a 'servir ao processo' e aquela por nós aceita, que atribui a essas medidas a finalidade de defender não o processo, mas o direito (provável) da parte que as pede [...] Daí por que não se pode recusar, à tutela cautelar, sua natureza instruental. Mas as medidas cautelares não são 'instrumento do instrumento', como pretendia Calamandrei, e sim, 
Para Proto Pisani, outra função da tutela cautelar é a economia processual, a fim de dispensar o custo do procedimento de cognição profunda quando este se mostra desnecessário. ${ }^{124}$ Não há dúvida de que a tutela cautelar também seja uma maneira de o juiz prestar a tutela jurisdicional. Através do poder acautelatório, o juiz garante os efeitos do processo como um todo. ${ }^{125}$ Calamandrei, em estudo essencial sobre as tutelas cautelares, classificou-as da seguintes maneira:

Tutela instrutória antecipada - geralmente são praticados ao longo do processo, mas em razão do perecimento da prova a ser produzida é realizada antes como a cautelar de antecipação de provas no sistema pátrio.

Tutela para assegurar a efetividade da execução - situações em que o devedor está se desfazendo indevidamente do patrimônio é possível pleitear uma tutela para evitar a dilapidação do patrimônio.

Tutelas antecipatórias - antecipando os provisoriamente efeitos finais da tutela. ${ }^{126}$

Além da cautelar descrita, baseada no poder de cautela do julgador e tipificada no Código, há, ainda, uma espécie de cautelar imprópria. Imprópria porque ela não é reversível: é utilizada apenas para se obter o bem da vida, que já é satisfativo com a própria liminar. É o caso, por exemplo, de transfusão de sangue em pessoas de determinada religião, em que o juiz autoriza o procedimento sem a oitiva da parte contrária. Outro exemplo é a demolição de imóvel que prejudique vizinhos: ação de dano infecto, a demolição ocorre sem qualquer contraditório. Segundo Bedaque, esse tipo de tutela é chamado de cautelar erroneamente, ${ }^{127}$ haja vista que faltam-lhes as principais características, quais sejam: reversibilidade, provisoriedade e instrumentalidade.

Ainda conforme Bedaque, nessa situação é prescindível o provimento final, porque "este é suficiente para satisfazer de forma plena o titular do direito e eliminar

instrumentos jurisdicionais criados para a proteção dos direitos. Mas esta constatação é simplesmente óbvia, pois não se diz constantemente que todo o processo civil serve de instrumento para a realização do direito material? E não se haverá de pretender que todo o direito processual civil, por ser instrumento, seja cautelar" (Ovídio Araújo Baptista da Silva, Curso de processo civil, vol. 3).

124. Cf. Proto Pisani, Lezioni di diritto processuale civile.

125. "A necessidade da tutela cautelar está ligada a uma normal disfunção do processo, incapaz de dar solução imediata aos problemas de direito material. Representa, na verdade, antídoto contra a demora para entrega da tutela jurisdicional" (José Roberto dos Santos Bedaque, op. cit., p. 124).

126. Piero Calamandrei, op. cit., p. 187.

127. José Roberto dos Santos Bedaque, op. cit., p. 244. 
a crise verificada na relação jurídica substancial", ${ }^{128}$ além de ser necessária a criação de um mecanismo de tutela sumária e satisfativa, apta à estabilização da decisão, a qual se torna definitiva, mas não imutável. ${ }^{129} \mathrm{O}$ autor defende que esse tipo de tutela somente seja concedido em circunstâncias que protejam um bem jurídico constitucional - por exemplo, a vida e a saúde -, sob pena de se ferir outras garantias constitucionais muito importantes - como o direito à ampla defesa, contraditório. Bedaque sugere que nessas condições o prejudicado poderia pleitear a mudança na decisão através do procedimento ordinário, o que possibilitaria uma cognição aprofundada sobre a questão, chegando-se a uma decisão definitiva. Como não há meio de desfazer o efeitos da decisão liminar já concedida, que é plenamente satisfativa, caso ela tenha se mostrado errada ao longo da instrução processual, deverá ser resolvida através de perdas e danos. Assim, o julgador deve analisar com muito cuidado as tutelas proferidas, uma vez que são irreversíveis e podem causar consequências danosas se deferidas incorretamente.

Trata-se, portanto, de tutelas urgentes, satisfativas e autônomas, pois é totalmente desnecessária uma tutela ulterior e definitiva. As medidas autossatisfativas são de criação doutrinária argentina e também adotam como critério para o deferimento a urgência da medida pleiteada. ${ }^{130}$

\subsubsection{Tutela antecipada}

Traçado o conceito de tutela jurisdicional, serão tratados os diversos tipos de tutela cuja característica principal é a sumariedade. ${ }^{131}$

\footnotetext{
128. Idem, ibidem, p. 244.

129. Idem, ibidem, p. 245.

130. 'Un requerimiento 'urgente' formulado al órgano jurisdiccional por los justiciables que se agota - de ahí lo de autosatisfactiva - con su despacho favorable; non siendo, entonces necesaria la iniciación de una ulterior acción principal para evitar su caducidad o decaimiento" (Jorge W. Peyrano, La medida autosatisfactiva: forma diferenciada constituye una expresión privilegiada del proceso urgente. Génesis y evolución. Medidas autosatisfactivas).

131. Conforme demonstramos no terceiro capítulo deste trabalho, a principal característica da tutela diferenciada é a sumariedade, não importando se o nomen iuris é tutela antecipada, tutela cautelar, tutela de urgência ou tutela de evidência. É claro que não se ignora as peculiaridades de cada uma dessas tutelas, mas elas serão analisadas apenas sob a óptica de suas características comuns.
} 
O instituto da antecipação da tutela, ${ }^{132}$ previsto no art. $273^{133}$ do CPC foi modificado pela Lei 8.952/1994, na chamada segunda onda renovatória do processo civil. ${ }^{134}$ Nessa época, ocorreram diversas reformas legislativas com o objetivo de buscar maior efetividade do processo em um curto período de tempo, e uma das grandes alterações foi justamente a criação do instituto da tutela antecipada. ${ }^{135}$ Conforme Marioni: “A técnica antecipatória visa apenas distribuir o ônus do tempo do processo"136 que sempre correu contra o autor, se concedida a tutela passa a correr contra o réu.

132. Para Teori Zavascki, a criação do instituto da tutela antecipada funcionou como uma purificação do processo cautelar, já que suas caracterítiscas estavam sendo desvirtuadas: "O que se operou, inquestionavelmente, foi a purificação do processo cautelar, que assim readquiriu sua finalidade clássica: a de instrumento para obtenção de medidas adequadas a tutelar o direito, sem satisfazêlo. Todas as demais medidas assecurativas, que constitutam satisfação antecipada de efeitos da tutela de mérito, já não caberão em ação cautelar, podendo ser, o melhor, devendo ser reclamadas na própria ação de conhecimento, exceto nos casos, raros, em que a lei expressamente prevê ação autônoma com tal finalidade, como, v.g., nos alimentos provisionais (CPC, art. 852). Postulá-las em ação cautelar, onde os requisitos para a concessão da tutela são menos rigorosos, significará fraudar o art. 273 do CPC, que, para satisfazer antecipadamente, supõe cognição em nível mais aprofundado, pois exige verossimilhança construída sobre prova inequívoca" (Teori Albino Zavascki, Medidas cautelares e medidas antecipatórias: técnicas diferentes, função constitucional semelhante, Revista de Processo, vol. 21. n. 82, p. 53-69).

133. "Art. 273. O juiz poderá, a requerimento da parte, antecipar, total ou parcialmente, os efeitos da tutela pretendida no pedido inicial, desde que, existindo prova inequívoca, se convença da verossimilhança da alegação".

134. O surgimento da tutela antecipada ocorreu como uma resposta à inefetividade do processo, que já era latente na década de 1990, e com a utilização indevida da tutela cautelar: "A utilização indiscriminada da tutela cautelar, portanto, apareceu como consequência da superação do procedimento ordinário, e da tendência, daí decorrente, da busca de sentenças rápidas e capazes de tornar efetivo o direito material. Dessa forma, o novo regime do art. 273 generalizou a possibilidade de antecipação da tutela no âmbito do procedimento comum do processo de conhecimento, corrigindo ao mesmo tempo o desvio do uso das ações cautelares e concedendo-se assim poderoso instrumento para a agilização e efetividade da jurisdição e do direito dela consequente" (Eliane Avelar Sertorio Octaviani, Tutela jurisdicional diferenciada e a efetividade do processo, Revista Jurídica, vol. 15, n. 2, p. 76).

135. Na Itália, alguns anos antes também foi adotada a tutela antecipada. O instituto na Itália e no Brasil guarda semelhanças e diferenças. Entre as principais diferenças, está a possibilidade de ocorrer somente quando a demanda não for contestada e se tratar de obrigação de condenação ao pagamento de uma soma em dinheiro. Outra característica do procedimento italiano é a possibilidade da tutela antecipada transitar em julgado mesmo que o processo principal seja extinto. "Sulla menzionata ultrattività non esercita alcuna incidenza il tipo di causa, da cui derivi l'evento anomalo della sopravvenuta estinzione. Poiché, nel perseguimento dei fini di economia e di accelerazione dei giudizi, la norme in proposito non distingue, l'ordinanza di condanna al pagamento delle somme non contestate vede sopravvivere i propri effeti, anche laddove l'estinzione del processo si verifichi per una rinunzia agli atti, pur provocata proprio da chi abbia inizialmente richiesto la sua pronunzia, atteso che l'evento estintivo non sfugge comunque al controllo della controparte costituita, di cui è necessaria l'accertazione '(art. 306, comma 1)" (Luigi Paolo Comoglio; Corrado Ferri; Michele Taruffo, op. cit., p. 692).

136. O autor faz uma bela referência de como deve ser a postura dos julgadores nesse novo cenário: "Não há razão para timidez no uso da tutela antecipatória, pois o remédio surgiu para eliminar um mal que já está instalado. É necessário que o juiz compreenda que não pode haver efetividade sem 
Costuma-se afirmar que a antecipação da tutela é a própria antecipação da decisão final de mérito. ${ }^{137}$ Ao contrário do que muitos afirmam, Teori Albino Zavascki expõe um conceito interessante de tutela antecipada: "a decisão que antecipa efeitos da tutela é espécie de provimento que não se confunde com a antecipação da sentença", ${ }^{138}$ mas é uma decisão que antecipa os efeitos executivos. ${ }^{139}$ Essa diferenciação é deveras importante, uma vez que entender a tutela antecipada como a própria fruição do direito é admitir um passo adiante para a satisfação do direito.

Sobre a percepção de que a tutela antecipada seria a antecipação dos efeitos da sentença, Carlos Alberto Alvaro de Oliveira faz uma importante consideração ao afirmar que ela não seria possível em um primeiro momento, em sede de cognição sumária, uma vez que a sentença é resultado de cognição plena e exauriente. A certeza expressada na sentença só é atingida após o exercício do contraditório e a exposição

riscos. A tutela antecipatória permite perceber que não é só a ação (o agir, a antecipação) que pode causar prejuízo, mas também a omissão. O juiz que se omite é tão nocivo quanto o juiz que julga mal. Prudência e equilíbrio não se confundem com medo, e a lentidão da justiça exige que o juiz deixe de lado o comodismo do procedimento ordinário - no qual alguns imaginam que ele não erra - para assumir as responsabilidades de um novo juiz, de um juiz que trata dos novos direitos e que também tem que entender - para cumprir a sua função sem deixar de lado a sua responsabilidade social - que as novas situações carentes de tutela não podem, em casos não raros, suportar o mesmo tempo que era gasto para a realização dos direitos de sessenta anos atrás, época em que foi publicada a célebre obra de Calamandrei, sistematizando as providências cautelares" (Luiz Guilherme Marinoni, A reforma do CPC e a efetividade do processo (tutela antecipatória, tutela monitória e tutela das obrigacões de fazer e de não fazer), Revista do Tribunal Regional do Trabalho da $9^{a}$ Região, vol. 21, n. 1, p. 61-62).

137. Fredie Didier Júnior, Paula Sarno Braga e Rafael Oliveira (op. cit.) ressaltam que, apesar da natureza de urgência da tutela cautelar e da tutela antecipada - e de muitas vezes elas serem confundidas entre si (sendo permitida até a fungibilidade entre os dois tipos) - é importante fazer uma simples distinção entre elas. A tutela cautelar é uma espécie de tutela jurisdicional, enquanto que a antecipação da tutela é uma tecnica processual.

138. Teori Albino Zavascki, Reforma do sistema processual civil brasileiro e reclassificação da tutela jurisdicional, Revista Forense, n. 346, p. 433-438.

139. No mesmo sentido entende Bedaque: "A antecipação não é da própria tutela cognitiva declaratória, constitutiva ou condenatória -, mas de efeitos a ela inerentes. O reconhecimento do direito somente virá com a sentença, que representa a tutela definitiva, apta a acabar com a crise no plano jurídico-material” (José Roberto dos Santos Bedaque, op. cit., p. 219). Ainda, para Rogério Aguiar Munhoz: "Quando se afirma que a antecipação de tutela tem natureza satisfativa, tem-se em mira o atingimento antecipado da fruição de algo que só em momento procedimental posterior seria alcançado, de mod que os atos satisfativos praticados antecipadamente nao se repetem uma vez confirmada a decisão antecipatória por sentença" (Rogério Aguiar Munhoz Soares, op. cit., p. 182). E, para Humberto Theodoro Júnior: "Com efeito, o que se autorizou ao juiz foi o uso de expedientes executivos, de variado teor antes mesmo de encerrar o processo de conhecimento e antes também de proferir a própria sentença de mérito. Está, destarte, credenciado o juiz a executar provisoriamente uma sentença que ainda não foi proferida, mas que as circunstâncias da causa o autorizam a prevê-la" (Humberto Theodoro Júnior, Tutela antecipada, Revista Juridica, vol. 45, n. 232, p. 8). 
pelas partes dos fatos e direitos. Então, não é correto falar em antecipação dos efeitos da sentença, pois não haverá certeza, apenas probabilidade, quando muito. ${ }^{140}$

Uma diferença que existe entre a antecipação da tutela e a tutela cautelar é a sua estabilidade. A tutela antecipada é provisória ao permitir a fruição também provisória dos efeitos da sentença. Por outro lado, a tutela cautelar é definitiva, já que a sentença transita em julgado e garante os efeitos do futuro processo principal, ou seja, da própria tutela satisfativa. Ainda as distingue o fator temporal de seus efeitos: a tutela antecipada tem efeitos perenes, os quais podem ser confirmados na sentença. O mesmo não ocorre com a tutela cautelar, pois seus efeitos tem eficácia temporária. Somente serão aplicáveis durante o processo cautelar e até a prolação da sentença de cognição aprofundada. ${ }^{141}$

Cumpre afirmar que a cognição na tutela antecipada é sumária no plano vertical. Ou seja, o juiz concede (ou não) a antecipação da tutela com os elementos presentes nos autos até aquele momento e de forma superficial.

A rigor, a antecipação de tutela por estar prevista no livro do processo de conhecimento não se aplica aos procedimentos especiais - execução e cautelar. Contudo, sequer a antecipação de tutela se aplica a todos os casos de processo de conhecimento, porque não existe lógica em estender a antecipação da tutela para as ações declaratórias e constitutivas, já que ela não se harmoniza com a finalidade desse tipo de provimento. Para darmos um exemplo esdrúxulo, não seria possível reconhecer em tutela antecipada que uma pessoa é pai e depois, ao longo da instrução processual, ficar comprovado o contrário. ${ }^{142}$ Uma das características da tutela antecipada é, portanto, a reversibilidade: ${ }^{143}$ no decorrer do processo, pode ser que se comprove que

140. Cf. Carlos Alberto Alvaro de Oliveira, Alcance e natureza da tutela antecipatória, Revista Forense, vol. 93 , n. 337, p. 55-66.

141. Cf. Fredie Didier Júnior, Paula Sarno Braga, Rafael Oliveira, op. cit.

142. Como assevera João Batista Lopes: "Na ação declaratória objetiva-se, segundo a doutrina dominante, desfazer incerteza sobre a existência ou inexistência da relação jurídica (rectios, a incerteza é subjetiva; o que se busca é o valor segurança emergente da coisa julgada). Como, então, antecipar a declaração de existência ou inexistência da relação jurídica? Como declarar provisoriamente que uma relação jurídica existe (ou inexiste?) [...] Por igual, a aplicação da tutela antecipada nas ações constitutivas também parece encontrar sérios obstáculos. É que a constituição ou desconstituição não pode ser provisória (v.g. não posso anular provisoriamente uma escritura ou um casamento). Dir-se-á que a antecipação pode ser total ou parcial de modo que, sem desconstituir propriamente o ato, é possível suspender seus efeitos (sua eficácia). Contudo, a suspensão dos efeitos do ato não se insere no campo das ações constitutivas, revestindo-se de caráter nitidamente cautelar" (João Batista Lopes, Antecipação da tutela e o art. 273 do CPC, Revista dos Tribunais, ano 85. vol. 729, p. 63-74).

143. "§ $2^{\circ}-$ Não se concederá a antecipação da tutela quando houver perigo de irreversibilidade do provimento antecipado". 
o autor não tinha razão e, assim, a tutela é cassada. O dispositivo legal, ao prescrever essa exigência, respeitou o princípio da segurança jurídica, preservando o direito do réu à reversão da decisão caso os fatos demonstrem que a razão está com ele. ${ }^{144}$ É importante ressaltar que o que deve ser irreversível são os efeitos da tutela antecipada, não a tutela em si. Tal diferenciação é importantíssima. Qualquer decisão é revogável, e o juiz pode cassar a tutela antecipada a qualquer momento, desde que trazidos novos elementos para os autos que provem que a concessão da tutela antecipada não foi uma decisão correta. Ou seja, os efeitos da tutela não devem causar um dano irreversível. Aqui cabe questionar: o que seria uma dano irreversível?

$\mathrm{Na}$ juridiction des référés, o entendimento da irreversibilidade ocorre quando a coisa não pode voltar ao seu estado natural, anterior à prolação da decisão, e mesmo nesses casos é possível ainda a indenização por perdas e danos. ${ }^{145} \mathrm{O}$ exemplo clássico é o da transfusão de sangue em determinados grupos religiosos. Muitas vezes, os médicos enfrentam situações em que a única chance de salvar a vida do paciente é realizar a transfusão de sangue, o que pode contrariar alguns dogmas religiosos. O juiz então concede a tutela antecipada com efeitos irreversíveis. Contudo, caso fosse negado esse pedido, os efeitos dessa decisão seriam igualmente irreversíveis, pois o paciente poderia falecer. Não há como voltar nem ao sangue original, nem à vida; a medida já se efetivou. Nesses casos, e somente nesses casos, em que o bem tutela pelo provimento antecipatório é maior que o direito de defesa do réu, deve ser deferida a tutela antecipada. Porém, deve ser analisada com parcimônia e com muito cuidado para não criar situações injustas. A irreversibilidade é praticamente impossível, já que a decisão que antecipou a tutela é provisória, sendo a coisa julgada a única coisa definitiva. ${ }^{146}$

Contudo, Marinoni ${ }^{147}$ aponta que, em muitas situações, o julgador acabará concedendo a tutela mesmo que ela seja irreversível para evitar um dano muito maior

\footnotetext{
144. Humberto Theodoro Júnior, Tutela antecipada, Revista Juridica, vol. 45, n. 232, p. 17.

145. Philipe Jestaz, L'urgence et les principes classiques du droit civil, p. 56.

146. Ovídio Araújo Baptista da Silva, Decisões interlocutórias e sentenças liminares, in: Da sentença liminar á nulidade da sentença, p. 14. Para o referido autor, "somente há prejuízo quando houver prejulgamento que impeça o juiz da sentença de mérito de proferir um julgamento em sentido divergente" (idem, ibidem).

147. Luiz Guilherme Marinoni, A reforma do CPC e a efetividade do processo (tutela antecipatória, tutela monitória e tutela das obrigacões de fazer e de não fazer), Revista do Tribunal Regional do Trabalho da $9^{a}$ Região, vol. 21, n. 1. 1996, p. 66. O entendimento desse autor é semelhante ao de Carlos Alberto Alvaro de Oliveira: “A meu ver, dentro do contexto específico da realidade brasileira, impõe-se realçar com mais força o valor da efetividade. O provimento cautelar, incusive
} 
ao autor - são os casos das tutelas autossatisfativas. ${ }^{148}$ Discordamos dessa posição, pois a tutela antecipada não pode ser utilizada para transferir o risco do autor para o réu. Se há risco de irreversibilidade da tutela ela não deverá ser concedida, exceção feita para situações que envolvam direitos fundamentais, como o direito à vida. A hipótese defendida por Marinoni e por muitos outros somente se justifica caso o bem da vida, protegido pela antecipação da tutela, seja maior do que o direito do réu à ampla defesa e ao contraditório. Se os efeitos da tutela antecipada forem irreversíveis, o réu não terá oportunidade de defesa e o próprio provimento antecipatório confundir-se-á com a sentença final de procedência. É o que Peyrano chama de tutelas autossatisfactiva. ${ }^{149}$

Em algumas províncias argentinas está prevista a tutela autossatisfativa. Não se trata de medida cautelar, com a característica da provisoriedade e da instrumentalidade, porque é a própria decisão final, cujos efeitos são quase sempre irreversíveis. A previsão desse tipo de tutela já resolve o problema teórico da instrumentalidade da tutela cautelar, pois não é necessária a propositura de uma ação de cognição plena e exauriente ou de um processo de execução - a decisão liminar basta. Contudo, sua utilização é restritíssima, cabível apenas em casos que envolvem direito à vida, à saúde física ou psíquica. ${ }^{150}$

Em decorrência lógica da irreversibilidade do provimento antecipatório, o provimento é provisório, já que a decisão definitiva será dada após a instrução processual, exercido o contraditório, ouvidas as partes, ou seja, com cognição profunda.

liminar, deve ser imitido, mesmo a custa de uma satisfação provisória, se a situação perigosa só pode ser evitada ou minimizada com a antecipação dos efeitos da futura sentença de mérito. A tanto, aliás, autoriza o Código de 73, ao facultar ao juiz 'determinar as medidas adequadas' para a prevenção do dano. Entre as duas concepções opostas que se digladiam nessa matéria, uma exigindo a contraposição dos interesses em conflito, outra privilegiando quem se apresente como provável titular do direito, inclino-me pela segunda, quando, sublinho, outra solução não puder ser encontrada para evitar o prejuízo. Claro está que, tanto quanto possível, o juiz deverá procurar minimizar os danos da contraparte. Nos casos limites, contudo, embora o possível efeito danoso ao interesse do demandado, não se confiura um emprego abusivo da cautela, se efetivamente presentes os pressupostos indispnesáveis à sua concessão" (Carlos Alberto Alvaro de Oliveira, Efetividade e processo cautelar, Revista de Processo, ano 19, n. 76).

148. Esse tipo de tutela é denominado "tutela de segurança" por Luiz Fux, Tutela de segurança e tutela de evidência (fundamentos da tutela antecipada).

149. Jorge W. Peyrano, op. cit.

150. Cf. Luis Luciano Gardella, Medidas autosatisfactivas: principios constitucionales aplicables. Trámite. Recursos. Medidas autosatisfactivas, p. 263. 
$\mathrm{O}$ art. 273 do CPC estabelece alguns requisitos para a concessão da tutela, entre elas: o perigo de dano irreparável, a verossimilhança do direito, o abuso de direito processual e a incontrovérsia do pedido. Interessante notar que o caput do art. 273 do CPC assevera que o juiz poderá deferir a tutela antecipada se presentes os requisitos exigidos na lei, isto é, a parte deve requerer a tutela, e o juiz, se convencido pelos argumentos e provas ali carreadas, em sede de cognição sumária, poderá deferir a tutela. O caput do art. 273 impõe dois requisitos para o deferimento da tutela antecipada: "desde que existindo prova inequívoca, se convença da verossimilhança da alegação". As expressões "prova inequívoca" e "verossimilhança da alegação" são, à primeira vista, contraditórias, pois, se algo é verossímil, não é certo, e não há certeza sobre essa alegação. No entanto, se a prova deve ser inequívoca, há certeza sobre a prova lançada aos autos, e os fatos ali comprovados são certos. Então, essas duas expressões como podem conviver no mesmo dispositivo legal ${ }^{151}$

Um dos principais requisitos da tutela antecipada é a prova inequívoca, que em uma primeira análise pode ser confundida com o fumus boni iuris da cautelar. No entanto, parece que a prova inequívoca exige um grau de probabilidade muito mais intenso do direito. Pois não basta a alegação dos fatos, mas é necessária prova verossímil dos fatos suficiente para convencer o julgador. ${ }^{152}$

Ainda sobre a diferenciação entre os tipos de tutela, Antonio Carratta explica que também existe essa discussão doutrinária na Itália. Para a tutela antecipada é necessário um grau mais aprofundado de certeza, uma certeza maior sobre as provas, enquanto para a tutela cautelar bastaria um juízo de probabilidade e não certeza. ${ }^{153}$

151. Dinamarco aponta a contradição formal existente entre essas duas expressões em A reforma do CPC, p. 145. Cf. Ernane Fidélis dos Santos, Novíssimos perfis do processo civil brasileiro, p. 36; José Carlos Barbosa Moreira, Antecipação de tutela: algumas questões controvertidas, Revista Síntese de Direito Civil e Processual Civil, ano III, n. 13, p. 5-13.

152. Assim entende Luiz Fux, que afirma que a prova inequívoca é irmã gêma do direito líquido e certo exigido no mandado de segurança: “A prova, via de regra, demonstra o 'provável', a 'verossimilhança', nunca a verdade plena que compõe o mundo da realidade fenomênica. Os fatos em si não mudam, porque a prova realiza-se num sentido diverso daquele que a realidade indica. Ora, se assim o é e se o legislador não se utiliza inutilmente de expressões, a exegese imposta é a de que 'prova inequívoca', para a concessão da tutela antecipada é alma gêmea da prova do direito líquido e certo para a concessão do mandamus. É a prova extreme de dúvidas, aquela cuja produção não deixa ao juízo outra alternativa senão a concessão da tutela antecipada" (op. cit., p. 348).

153. 'Si è anzitutto evidenziato come il 'giudizio' di verosimiglianza presupposto dai provvedimenti sommari non cautelari, cioè dai c.d. accertamenti con prevalente funzione esecutiva, è diverso, sotto un profilo strutturale, da quello alla base dei provvedimenti sommari cautelari e come, sebbene in entrambi i casi il giudizio si fondi sulla verosimiglianza dei fatti allegati, si possa distinguere a seconda che il giudizio di verosimiglianza dipenda dalla valutazione delle risultanze probatorie acquisite oppure prescinda dall'acquisizione dei mezzi di prova e si fondi sulla 
Mais adiante, o autor refuta essa ideia de divisão do tipo de cognição em tutela cautelar e tutela antecipada, uma vez que ambas partem do pressuposto, da limitação da cognição, da limitação dos elementos levados a juízo, fazendo com que a cognição seja superficial e parcial. O que existe de diferente entre os dois tipos de tutela, portanto, são os requisitos para a sua concessão. ${ }^{154}$

Conforme Barbosa Moreira, essa confusão decorre da qualificação do termo "prova inequívoca", que para alguns autores teria um grau de convencimento mais intenso que o fumus boni iuri. Ou seja, haveria tanta certeza com a prova produzida e juntada, geralmente, pelo autor, que a própria tutela antecipada se confundiria com a procedência do pedido. No entanto, esse problema é fictício pois o dispositivo legal é claro ao asseverar que o juiz deverá se convencer da inequivocidade da prova. Ou seja, se a prova foi suficiente para o convencimento do juiz, ela foi suficiente para o deferimento da tutela. Ademais, a expressão de que a prova deve convencer o juiz revela-se redundante se considerarmos o nosso sistema processual da persuasão legal, em que o juiz é livre para se convencer das provas. ${ }^{155}$ A solução proposta por Barbosa Moreira é baseada em dois questionamentos. Primeiro: a prova é inequívoca, ou seja, dá margem a apenas um único entendimento? Ela não provoca ambiguidades, dúvidas?

probabilità dell'esistenza del fatto affermato. E sulla base di questa riflessione si è impostata la differenza fra la cognizione dei provvedimenti sommari non cautelari, che sarebbe verosimile secondo il primo significato, e cioè sarebbe il frutto di una valutazione dell'efficacia dei mezzi probatori e nongià di un mero calcolo probabilistico da quella dei provvedimenti sommari cautelari, che, invece sarebbe verosimile secondo l'ultimo significato, potendo esse fondata anche soltanto sulla era attendibilità delle allegazioni valutata secondo un giudizio formulato in termini di probabilità e non di certeza" (Antonio Carratta, Profili sistematici della tutela anticipatoria, $\mathrm{p}$. 245).

154. "Certo, si potrebbe obiettare, e fondatamente, che anche in questi casi si tratta di cognizione sommaria perché non completa e non definitiva. Ma è indubbio che si possano profilare delle nette differenze sul piano della qualità dell'accertamento fra la cognizione sommaria perché parziale o superficiale e la cognizione sommaria perché non definitiva" (idem, ibidem, p. 247).

155. "A nosso ver, falsa é a premissa de que se parte. A força persuasiva da prova, a sua capacidade para persuadir o juiz, está suficientemente assinalada no texto legal pela oração 'desde que [...] se convença da verossimilhança da alegação'. Se é indispensável que o juiz se convença, e se o convencimento do juiz não se pode basear senão em alguma prova, dizer que essa prova tem de ser convincente é dizer o mesmo que está dito alhures acerca do juiz. Gira-se num círculo vicioso: o juiz deve convencer-se da verossimilhança da alegação, e a prova deve ser tal que disso o convença. Em semelhante perspectiva, sugerir, como há quem sugira, que se traduza 'verossimilhança' por 'probabilidade' desloca o problema, sem resolvê-lo: continuará a ser inevitável a redundância. Claro está, com efeito, que se o juiz se convenceu de ser provável a alegação, é sinal de que a prova teve por força a virtude de convencê-lo dessa probabilidade. Em quaisquer interpretações desse gênero, imputa-se à lei o defeito de expressar duas vezes a mesma ideia, ou melhor, de formular duas vezes o mesmo pressuposto da antecipação: uma ao qualificar de 'inequívoca' a prova, outra ao exigir que à vista dela o juiz 'se convença"' (José Carlos Barbosa Moreira, Antecipação de tutela: algumas questões controvertidas, Revista Síntese de direito civil e processual civil, ano III, n. 13, p. 5-13). 
Se positiva a resposta, segundo: a prova é suficiente para convencer o julgador? Se a resposta for novamente positiva, a tutela será deferida.

Continuando a análise do art. 273 do CPC, vemos que o inciso I do referido dispositivo legal prevê hipótese de antecipação de tutela em situações que ofereçam risco de frustração da tutela jurisdicional final. Ou seja, a tutela antecipada tem a mesma natureza da tutela cautelar, uma vez que o objetivo é assegurar o resultado da tutela jurisdicional final.

A hipótese do inciso III da lei prevê um abuso do direito de defesa. A ideia do legislador aqui é outra, não está vinculada ao perigo de dano nem a assegurar o resultado final da tutela jurisdicional, mas apenas penalizar o réu em caso de abuso de direito de defesa. A medida se assemelha às situações prescritas no capítulo sobre litigância de má-fé. A razão para essa antecipação com fundamento no abuso do direito de defesa deve-se ao fato de que a atitude do réu coloca em risco a efetivação do direito do autor. Assim, não basta o mero abuso, mas é necessário também que o direito do autor seja evidente e que somado ao abuso do réu o coloca em perigo. ${ }^{156}$

É a denominada tutela antecipada sancionatória. A ideia aqui é distribuir o ônus do tempo também para o réu. ${ }^{157}$ Não há dúvida de que o tempo é fator de grande prejuízo para o autor que se vê impedido de usufruir o bem da vida que foi buscar no Judiciário. Ao repassar esse ônus do tempo para o réu, antecipando a tutela em caso de abuso de direito de defesa, o juiz assume que o tempo é um ônus e deve ser distribuído de forma igualitária. ${ }^{158}$

156. "Não se pode perder vista, para a correta aplicação das regras relativas à antecipação dos efeitos da tutela final, que a providência está sempre ligada à efetiva necessidade. Nessa linha, somente deve ser concedida quando imprescindível para assegurar a efetividade do processo. Tratando-se de abuso do direito de defesa, portanto, somente se justifica a incidência da tutela antecipada se desse comportamento resultar atraso indevido na entrega da tutela. A mera dedução de razões completamente infundadas não autoriza a antecipação" (José Roberto dos Santos Bedaque, op. cit., p. 361).

157. Interessante lembrar que o fator tempo sempre foi muito importante para a análise processual e a busca de novas soluções. Foi o tempo que fez com que Carnelutti formulasse a teoria dos provimentos cautelares e a necessidade de sua adoção na legislação processual civil, haja vista a urgência que determinadas tutelas requeriam. Essa ideia de evitar o dano maior que o tempo pode acarretar sem que o processo dê uma solução está muito presente no trabalho de Carnelutti. Cf. Francesco Carnelutti, Diritto e processo, p. 354.

158. "Pretender distribuir o tempo implica em vê-lo como ônus, e essa compreensão exige a prévia constatação de que ele não pode ser visto como algo neutro ou indiferente ao autor e ao réu. Se o autor precisa de tempo para receber o bem da vida a que persegue, é lógico que o processo evidentemente que no caso da sentença de procedência - sera tanto mais efetivio quanto mais rápido for. De modo que a técnica antecipatória baseada em abuso de direito de defesa ou em incontrovérsia de parcela da demanda possui o objetivo fundamental de dar tratamento racional ao tempo do processo, permitindo que decisões sobre o érito sejam tomadas no seu curso, desde que 
Claro que a própria existência do processo já é um dano experimentado pela parte, obrigada a ajuizar a ação por não conseguir resolver a questão de forma extrajudicial. Até a propositura da ação e o julgamento final pelo Judiciário, a parte arcará com esse dano. Trata-se do dano marginal decorrente da demora natural do processo. Quando o réu age de maneira desleal, atrasando indevidamente o processo e fazendo com que o dano enfrentado pelo autor em decorrência do tempo aumente, aplica-se o referido dispositivo legal, revertendo o ônus do tempo contra o réu e tirando esse fardo do autor. $^{159}$

Ainda, é importante a hipótese prevista no $\S 6^{\circ}$ do art. 273 que trata sobre a inexistência de controvérsia sobre os pedidos formulados na inicial. Assim, a plausibilidade dos fatos é essencial. $\mathrm{O} \S 6^{\circ}$ do art. 273 refere-se à incontrovérsia não no sentido de revelia, confissão ou reconhecimento jurídico, mas no de direito evidente, daquele pedido que ao longo da instrução processual se mostrou incontroverso, não mais havendo razões para não ser outorgada a tutela (ainda que parcialmente) apenas ao fim do processo, podendo ser antecipada. ${ }^{160}$

A cognição aqui é plena e exauriente, uma vez comprovada a incontrovérsia do pedido. ${ }^{161}$ Bedaque, em seu estudo sobre as cautelares e as tutelas antecipadas, questiona: é possível considerar um caráter cautelar na tutela antecipada mesmo que esta desenvolva a tutela jurisdicional definitiva, ainda que de forma provisória? ${ }^{162}$

presentes o abuso do direito de defesa ou a incontrovérsia de parcela da demanda. Para tanto, partese da premissa de que não é racional obrigar o autor a suportar a demora do processo quando há abuso do direito de defesa ou quando parcela da demanda pode ser definida desde logo" (Luiz Guilherme Marinoni, $\mathrm{O}$ direito à efetividade da tutela jurisdicional na perspectiva da teoria dos direitos fundamentais, Gênesis: Revista de Direito Processual Civil, n. 28, p. 217-432).

159. “A tutela antecipada sancionatória está inserida nesse contexto. Na sua técnica, caso seja provável o direit do demandante e o dano marginal do processo seja agravado pela atitude desleal do demandado, evidenciada no abuso do direito de defesa ou no manifesto proposito protelatório (infra, n. 31), é possível a antecipação da tutela jurisdicional. Com isso, o dano marginal que ao início é suportado pelo demandante, passa a ser suportado pelo demandado" (Bruno Vasconcelos Carrilho Lopes, Tutela antecipada sancionatória (art. 273, inc. II, do Código de Processo Civil), p. 63).

160 Luiz Guilherme Marinoni, $\mathrm{O}$ direito à efetividade da tutela jurisdicional na perspectiva da teoria dos direitos fundamentais, Gênesis: Revista de Direito Processual Civil, n. 28, p. 217-432.

161. "Na tutela antecipada da parte do pedido fundada em fatos incontroversos, de outra parte, a cognição realizada pelo magistrado é quase exauriente, não sendo apropriado falar em mera probabilidade, mas praticamente em certeza da existência do direito pleiteado". Bruno Vasconcelos Carrilho Lopes. Tutela antecipada sancionatória (art. 273, inc. II, do Código de Processo Civil), p. 58.

162. José Roberto dos Santos Bedaque, op. cit., p. 308. 
Parte da doutrina ${ }^{163}$ considera que a principal diferença entre os dois tipos é a tutela cautelar apenas assegurar o resultado final do processo, enquanto a tutela antecipada é a própria fruição dos efeitos finais da sentença, como se ela já existisse. Ainda, outra diferenciação seria a cognição de ambas: na tutela antecipada seriam analisados o direito material, a verossimilhança das alegações, e tratar-se-ia de um juízo de probabilidade; na cautelar, verificar-se-ia o risco de demora do processo e o possível perecimento deste caso não ocorresse naquele momento. Para Bedaque ${ }^{164}$ essa diferença não existe, e ambas tratam de espécies de tutelas de urgência cautelares, uma vez que não resolvem a questão de direito material posta definitivamente, mas de forma provisória, ${ }^{165}$ servindo para determinar soluções urgentes para as questões postas, de forma que a tutela jurisdicional final não perca sua utilidade.

Apesar de a tutela cautelar e a tutela antecipada serem diferentes quanto aos requisitos para o deferimento da tutela, as duas espécies fazem parte do gênero de tutela de urgência. Assim, torna-se necessária certa compatibilização entre os dois ritos processuais a fim de evitar que erros aconteçam. Dessa forma, em 2002 foi incluído no art. $273 \mathrm{o} \S 7^{\circ}$, que prevê a fungibilidade entre a tutela cautelar e a tutela antecipada. Com esse parágrafo, uma vez mais ficou comprovada a tendência atual do processo civil: sua instrumentalidade em favor do direito material, não sendo ele um fim em si. ${ }^{166}$ Dinamarco enxerga com bons olhos a introdução do $\S 7^{\circ}$, já que deve agregar muito à efetividade das tutelas urgentes e unificar as teorias sobre as tutelas de urgência, provendo assim uma tutela eficaz e efetiva às partes, sem que o julgador fique preso a formalismos desnecessários. ${ }^{167}$

Por fim, cabe lembrar que cada um dos requisitos da tutela antecipada independem entre si e não devem ser necessarimente cumulados, isso porque cada um dos tipos previstos nos incisos do art. 273 do CPC tem natureza diferente e específica. Isso porque podemos considerar três tipos principais: 1) a tutela baseada na urgência do

163. Cf. Adroaldo Furtado Fabrício, Breves notas sobre provimentos antecipatórios, cautelares e liminares, Revista da Ajuris, vol. 66; Luiz Guilherme Marinoni, Antecipação da tutela.

164. José Roberto dos Santos Bedaque, op. cit., p. 315.

165. Rogério Aguiar Munhoz tem um posicionamento diferente. Para esse autor, a suposta provisoriedade da tutela antecipada não importaria, uma vez que a fruição do bem tutelado é definitiva, embora seja provisória a decisão que a conceda. Rogério Aguiar Munhoz Soares, op. cit., p. 182.

166. Cf. Dias Figueira Júnior, Comentários à novíssima reforma do CPC: lei n. 10.444, de 07.05.2002, p. 118; Bruno Vasconcelos Carrilho Lopes, Tutela antecipada sancionatória (art. 273, inc. II, do Código de Processo Civil), p. 59.

167. Cândido Rangel Dinamarco, A reforma da reforma, p. 91. 
direito pleiteado e na verossimilhança das alegações; 2) a tutela antecipada sancionatória que serve como uma sanção ao réu; 3) a tutela antecipada concedida no fato incontroverso que já é o próprio julgamento da demanda.

\subsubsection{Tutela diferenciada não urgente}

Abordaremos agora a tutela diferenciada não urgente. De acordo com Bedaque, esse tipo de tutela pode ser denominado tutela sumária não cautelar, porque não há o risco de urgência na antecipação ou de cautelaridade da tutela que justifique essa análise liminar. A justificativa para a concessão da liminar baseia-se na evidência do direito pleiteado pelo autor e na ausência de fatos a serem impugnados pelo réu. Como se trata de uma situação bastante específica, a concessão da liminar nessa hipótese deve ser analisada com muito cuidado pelo juiz, sendo deferida apenas em situações excepcionais, para evitar qualquer prejuízo às partes. ${ }^{168}$

\subsubsection{Tutela de evidência}

O direito evidente é uma expressão sempre muito usada quando as pretensões da parte são evidentes, claras, sem qualquer possibilidade de serem discutidas. O direito evidente pode ser comparado ao direito líquido e certo do impetrante que consegue sua tutela no mandamus, e mesmo com a certeza do título executivo, que autoriza o exequente a expropriar bens do executado sem a necessidade de instauração de

168. "O recurso à tutela sumária não cautelar deve ser excepcional, cabendo ao legislador estabelecer, de forma específica, quais os direitos suscetíveis de proteção por essa via urgente, regulando minuciosamente o procedimento para obtenção do provimento" (José Roberto dos Santos Bedaque, op. cit., p. 124). 
contraditório. ${ }^{169}$ A certeza do direito evidente é muito mais forte que a do fumus boni iuris e a da verossimilhança das alegações. ${ }^{170}$

Muito se critica a suposta certeza que existiria na tutela de evidência. É preciso ter em mente que a certeza absoluta é impossível, mas se pode alcançar verossimilhança em grau tão elevado que ela se assume como certeza e verdade absoluta, permitindo ao juiz conceder a tutela. Nesse sentido, Ovídio Araújo Baptista da Silva trata da tutela da aparência (que aqui podemos entender como a tutela de evidência) considerando-a plenamente possível no nosso sistema processual: ela não passa de uma verossimilhança ao extremo. É o que ocorre nos títulos executivos extrajudiciais em que o legislador criou um documento que reflete a evidência ou a aparência do direito e autoriza o julgador a executar de imediato, sem a necessidade de uma cognição plena e exauriente. ${ }^{171}$

169. Recentemente trabalhei em um caso de direito evidente, em que claramente foi deferida a tutela liminar não pela urgência no pleito, mas pela evidência do direito. $O$ cliente comprara um apartamento novo de um terceiro (ou seja, não diretamente da incorporadora), e o apartamento não seria utilizado para residência, somente para locação. No entanto, quando foi realizada a vistoria do apartamento, o cliente verificou que apesar de terem sido entregues as chaves, ainda não tinha sido realizado o cabeamento da energia elétrica. Ou seja, não seria possível utilizar nenhum aparelho eletrônico, acender as luzes e mesmo usar o elevador. O apartamento não estava completamente entregue e não era possível alugá-lo. Como meu cliente não iria residir no apartamento, foram algumas meses negociando com a incorporadora a ligação da energia elétrica, que não ocorria. Foi necessário então ajuizar uma ação de obrigação de fazer cumulada com indenizatória (pelo valor dos aluguéis que foram perdidos) para que, somente então, a incorporadora fizesse o cabeamento da energia elétrica. O juiz deferiu o pedido liminarmente, não pela urgência, já que o meu cliente não iria utilizar como residência, mas, sim, baseado na evidência do direito.

170. Luiz Fux (op. cit., p. 308), ao tratar da tutela de evidência, sustenta que ela pertence ao campo da justiça: "A tutela do direito evidente pertence ao campo da 'justiça', e não estritamente ao campo do direito. A Escola da 'norma fundamental' de Kelsen, bem como os neopositivistas, não enxergaram o valor 'justiça' como fundamento do direito senão como uma 'aspiração emocional'. Entretanto, convence-nos a doutrina de Miguel Reale de que a 'teoria da justiça' como fundamento do direito nunca alcançou contornos tão vivos e originais como em nosso tempo, sobretudo à medida que vieram adquirindo maior profundidade os estudos de axiologia ou teoria dos valores.

171. "O que é o título executivo senão um instrumento que a ordem jurídica outorga proteção pela aparência que ele reflete? O título executivo, cuja elaboração durou alguns séculos, e que poderia ser escolhido como o símbolo da vicilização industrial moderna, é uma forma genial que os processualistas inventaram de proteger a aparência. Não há nada de extraordinário, e nem de errado na tutela jurisdicional da aparência. O que, na verdade, não passa de uma ideologia equivocada é imaginar que o procedimento ordinário é feito para a descoberta da verdade. Ora, a busca da verdade é um ideal intangível mesmo nas denominadas ciências exatas. As verdades científicas são sempre provisórias. Como disse um filósofo francês, toda descoberta científica é sempre a reforma de uma ilusão anterior. Os grandes mestres da doutrina da prova sempre disseram que a função probatória desenvolvida no processo tem por fim estabelecer, não os fatos verdadeiros, e sim os fatos tidos por verdadeiros". Ovídio Araújo Baptista da Silva. Teoria da ação cautelar. In: Da sentença liminar à nulidade da sentença. Rio de Janeiro: Forense, 2002, p. 77. 
O direito evidente é muito comum no sistema anglo-saxônico, no qual costuma haver o julgamento prima facie evidente, pela facilidade de criação jurisprudencial daqueles países. Contudo, apesar de o Brasil ter herança de sistema de civil law, é evidente sua aproximação com a cultura dos países de common law, e é normal que algumas características sejam assimiladas.

Como se trata de um direito evidente, o julgador deve ter consciência de que dificilmente a tutela deferida será modificada, pois os elementos que já foram submetidos à sua cognição ${ }^{172}$ são suficientes para o deferimento da tutela, uma vez que o que se oferece para apreciação do juízo é o próprio objeto litigioso. ${ }^{173}$ Lógico que o julgador também deve ponderar o risco de irreversibilidade da tutela e não deferir quando este for muito alto.

Luiz Fuz, um dos autores do projeto do novo Código de Processo Civil, estudou profundamente a tutela evidente, assim definindo-a: "Sob o ângulo civil, o direito evidente é aquele que se projeta no âmbito do sujeito de direito que postula. Sob o prima processual, é evidente o direito cuja prova dos fatos sobre os quais incide revelaos incontestáveis ou ao menos impassíveis de contestação séria". ${ }^{174}$

A prova, portanto, é um elemento importantíssimo para o direito evidente. Através dela será feito o trabalho de convencimento do julgador para o deferimento da tutela. Ou seja, é direito evidente quando a prova documental dos fatos mostrar-se líquida e certa. Da mesma maneira, também é evidente o direito que versa sobre fatos incontroversos, públicos, notórios ou o direito baseado em discussões simplesmente jurídicas e não fáticas. No direito evidente incluem-se também os fatos já decididos e transitados em outro processo, utilizados como provas emprestadas. Uma inicial fundamentação baseada em fatos notórios, amplamente divulgados e de conhecimento geral, deverá ser deferida, pois o direito é evidente. Os fatos incontroversos também merecem serem tutelados de imediato, porque não serão discutidos pelo réu, dada sua incontrovérsia. De igual modo, uma discussão baseada exclusivamente no direito, que

\footnotetext{
172. A cognição aqui nessa etapa é exauriente, isso porque o direito é evidente e não há mais nada a ser investigado. Não importa, se houve uma sumarização do procedimento, isso porque a sumarização na cognição não ocorreu.

173. Continua ainda Fux (op. cit., p. 309): “A margem de erro é aquela que se verifica em todo provimento mesmo de cognição dita exauriente e como consectário da humanidade do julgador”. Conforme o autor, prevalece a máxima de que, se é evidente, não precisa ser descoberto. Então, já se demonstra ao juízo todo o objeto do processo e essa seria a razão a de deferir de imediato a tutela, ainda que tenham sido apresentados somente a versão dos fatos do autor.

174. Idem, ibidem, p. 30.
} 
não merece prova, será calcada exclusivamente no entendimento do juiz sobre aquele dispositivo legal, sobre o direito discutido. Assim, cabe o julgamento antecipado da lide, sendo desnecessária a realização de prova e o saneamento do processo. Ainda, a prova emprestada, se realizada no outro processo preservando o contraditório e as demais garantias constitucionais-processuais, demonstra a evidência dos fatos e, consequentemente, autoriza o deferimento imediato da tutela. Também é evidente o direito calcado em sentença transitada em julgado: não se trata da execução da sentença, mas de quando uma das provas juntadas pelo autor é uma sentença transitada em julgado - não há razão para não ser considerada fato evidente a disposição transitada em julgado na sentença. Por fim, ainda devemos ponderar que também é evidente o direito fundamentado em prescrição ou decadência. Nosso sistema processual sempre admitiu o julgamento antecipado baseado nessas duas situações de direito, caso restasse comprovada (evidente) a prescrição ou decadência o juiz deve acolher de imediato, sem maiores delongas. Não há que se falar em periculum in mora nessa hipótese, pois a concessão da tutela do direito evidente se baseia na certeza do direito, não na necessidade de sua concessão em razão do perigo da tutela perecer. Dessa forma, a flexibilização do procedimento para a concessão da tutela de evidência é fundamental, haja vista que somente em um procedimento mais flexível é possível deferir tal tutela sem que seja necessário aguardar a prolação da sentença.

Diante dessa flexibilização procedimental surge a discussão do princípio do devido processo legal. Até que ponto é possível flexibilizar o procedimento em nome da efetividade dos direitos sem respeitar os princípios processuais constitucionais? A flexibilização procedimental não significa, necessariamente, uma violação ao devido processo legal, e o fato de uma tutela ser concedida de forma antecipada, por ser direito evidente, sem a oitiva da parte contrária não significa que a parte contrária não será ouvida em hipótese alguma. Significa apenas que o procedimento será flexibilizado para a concessão da tutela, podendo esta, se for o caso, ser revogada, se o juiz ao longo da instrução processual se convencer de que o autor não tenha direito.

O instituto do direito evidente ainda pode ser aproximado do instituto dos référés franceses. Na França, existem diversos tipos de référé, ${ }^{175}$ tutelando diversas situações

175. "Sotto il generico termine référé vanno ricomprese, quindi, tutte le varie tipologie di référés che vengono accomunate in base alla presenza di alcuni tratti fondamentali, descritti dall'art. 484 del CPC francese, il quale definisce la relativa ordinanza come 'una decisione provvisoria emanata su domanda di una parte, l'altra comparsa o citata, nei casi in cui la legge conferisce ad un giudice, che non è investito del merito, il potere di ordinare immediatamente le misure necessarie'. Nella 
da vida com um procedimento específico para cada hipótese, nem todos necessarimente relacionados à urgência da tutela. Falaremos rapidamente sobre cada um deles e, especialmente do référé provision, a grande inovação do direito francês. Concebido inicialmente para tutelar situações urgentes, como previsto no art. $808^{176}$ do Nouveau Code de Procédure Civile, ${ }^{177}$ o référé surgiu em 1685, via decreto que determinava o comparecimento das partes a juízo em situações de urgência. $O$ juiz possuía um poder discricionário, determinando uma ordem provisória para regular a situação urgente ali apresentada. Interessante ressaltar que, desde os primórdios do instituto, era assegurado o direito ao contraditório.

Com o Código de Processo Civil de 1806, o référé passou a vigorar em toda a França. Contudo, foi a jurisprudência que o consolidou, ao aplicá-lo em diversas situações de urgência, ampliando o procedimento para as outras jurisdições civis. Nesse momento, a autoridade competente para deferir o référé passou a ser o presidente do tribunal civil. Em 28 de novembro de 1955 foi instituído o référé administrativo e o presidente do tribunal administrativo era o responsável por deferir a tutela.

citata disposizione sono contenuti gli elementi caratterizzante ogni tipo di référé, quali: la preventiva instaurazione del contraddittorio; la rapidità-celerità e semplicità del procedimento; l'efficacia provvisoria del provvedimento. Al contrario, l'urgenza non rientra più nelle caratteristiche generali dell'istituto in esame, non essendo più attualmente richieta per alcune forme speciali di référé, le quali restano, pur sempre le gate all'esigenza della celerità e in cui l'urgenza rimane, in alcuni casi 'soggiacente" (Giovanni Bonato, I référés nell'ordinamento francese, in: Antonio Carratta (org.), op. cit.).

176 "Dans tous les cas d'urgence, le président du tribunal de grande instance peut ordonner en référé toutes les mesures qui ne se heurtent à aucune contestation sérieuse ou que justifie l'existence d'un différend".

177. O sistema processual francês sempre foi muito desformalizado e durante a década de 70 sofreu grandes reformas que o tornaram mais burocratizado, mas ao mesmo tempo conseguiram ganhar em eficiência. Os franceses conseguiram encontrar um equilíbrio entre o formalismo, as garantias processuais e a eficiência no processo civil. A esse respeito veja o entendimento de Francesco Fradeani analisando os diversos sistemas europeus, entre ele o francês: "In questi ultimi decenni, il sistema processuale civile francese è stato profondamente riformato con l'entrata in vigore rispettivamente, nel 1975 del nouveau code de procédure civile, nel 1978 del code de l'organization judiciaire, infine negli anni 1991-1993 del processo esecutivo innovato. Ai fini della presente indagine due aspetti emergono chiaramente dal nuovo assetto normativo: da un lato, la notevole complessità e burocratizzazione dell'apparato giudiziario francese nel campo della giustizia civile; dall'altro, ma potrebbe anche dirsi, nonostante ciò, una visione d'insieme coerente con i valori fondanti il vigente sistema costituzionale, chiara nel linguaggio tecnico utilizzato, capace di creare nei fatti un soddisfacente equilibrio tra le istanze di rapidità ed effettività che emergono prepotenti dalla società moderna ed il sacrosanto rispetto dei principi del giuto processo a cognizione e contraddittorio pieni ed esaurienti" (Francesco Fradeani, I pressuposti e gli effetti delle misure cauteari in Europa: l'esperienza francese ed inglese, in: Antonio Carratta (org.), op. cit.). 
Diversos regulamentos, decretos e leis permitiram a consolidação do instituto do référé na França e sua aplicação nos diversos tribunais franceses. Atualmente, o référé é previsto no Código de Processo Civil francês de forma genérica nos arts. 484-492 e nos arts. 808-811 que disciplinam o référé perante o presidente do tribunal de grande instance. ${ }^{178}$ Trata-se de procedimento de cognição sumária que preza a agilidade e simplicidade. Presente em todas as jurisdições francesas, pode ser instaurado antes ou durante o curso do processo e ter o escopo de regular uma situação jurídica de maneira provisória, ${ }^{179}$ dando origem a um título executivo já plenamente executável e independente de uma ação principal. Assim, as principais características do référé são: sumariedade; provisoriedade; mitigação da instrumentalidade; contraditoriedade; executoriedade imediata da medida. ${ }^{180}$

Os référés gerais são aplicados em todos os tribunais franceses, independentemente da matéria que tenha por objeto. São divididos em référé de urgência (référé classique e référé prévention) e référé de tutela de evidência (référé provision). Para os primeiros, há o requisito da urgência na tutela pleiteada (periculum in mora), enquanto, para os segundos, não há, bastando que a tutela pleiteada seja evidente e que a contestação apresentada pelo réu não seja séria. Ainda há os référés especiais, que são específicos e se aplicam em algumas justiças especializadas e em situações determinadas. Esses référés existem por dois motivos: evitar qualquer hesitação dos tribunais em aplicar référé geral em determinadas situações já previstas; ignorar, necessariamente, requisitos específicos do référé geral em algumas situações predeterminadas - por exemplo, o référé probatoire, cujos requisitos são a urgência ou a ausência de contestação séria e a necessidade de se produzir prova em procedimento de cognição sumária. ${ }^{181}$

Previsto no art. 808 do Código de Processo Civil francês, o référé classique requer urgência, e seu conteúdo pode ser acautelatório quanto antecipatório. É um procedimento geral e está ligado a um poder geral de cautela dos juízes. O magistrado, quando da análise, procura equilibrar os interesses das partes, agindo mais em juízo de

178. Dino Buoncristiani, Sistema dei refere: tutela cautelare dal pregiudizio e tutela urgente senza prégiudizio, Rivista Trimestrale di Procedura Civile, n. 2.

179. "[...] il compito assegnato al giudice del référé è quello di offrire uma regolamentazione provvisoria ad uma situazione litigiosa, in modo da non prendere posizione sul merito della lite ed anzi da isolare e congelare il diritto contesto" (idem, ibidem, p. 590).

180. Mélina Douchy-Oudot, Procédure civile.

181. Idem, ibidem. 
equidade do que com base no direito material. Nesse tipo de référé, são imprescindíveis a ausência de contestação séria ${ }^{182}$ e a existência de uma disputa real entre as partes. ${ }^{183}$ Portanto, as tutelas do référé classique são concedidas para regular uma situação urgente, baseadas no periculum in mora e na existência de uma lide entre as partes.

Previsto no art. 809 do Código de Processo Civil francês, o référé prévention também tem a urgência como principal requisito, e possui, igualmente, caráter antecipatório ou conservativo. É utilizado para proteger ou evitar situações de dano iminente, mesmo em casos de existência de contestação séria. ${ }^{184}$ Aqui, portanto, para a concessão da tutela há uma análise mais profunda da existência do direito e do efetivo dano que a não concessão da tutela pode ocasionar; ou seja, há uma análise mais profunda do fumus boni iuris. ${ }^{185}$

A principal diferença entre essas duas espécies é que, no référé classique, exigese ausência de contestação séria e a existência de uma lide entre as partes, enquanto, référé prévention, basta o dano iminente, mesmo que a contestação seja séria. ${ }^{186}$

182. O requisito da ausência da contestação séria surge em quase todos os tipos de référé e também surgirá no processo societário italiano. A doutrina não define bem o que seria a contestação séria, mas pode-se entender que é quando a contestação apresentada pelo réu não se sustenta, mostrando ainda mais a evidência do direito do autor, seria o óbvio e o inegável. Cf. Mélina Douchy-Oudot, Procédure civile, p. 275: “[...] l'absence de contestation sérieuse est requise car sinon cela reviendrait à demander au juge des référé de trancher le litige lui-même. La mesure demandée ne doit pas se heurter à une contestation sérieuse. Le juge ne doit pas avoir à trancher une question au fond pour décider si l'octroi de la mesure este judicieux ou non. Selon le mot d'un auteur, le juge des référés est le juge de l'évident et de l'incontestable. De façon générale, le juge ne doit pas avoir à trancher une difficulté sérieuse nécessitant d'apprécier le bien-fondé des prétentions des parties. Il ne doit pas par exemple avoir à décider si le fait pour une radio locale d'émettre ses émissions sans autorisation constitue un acte de concurrence déloyale".

183. "Article 808. Dans tous les cas d'urgence, le président du tribunal de grande instance peut ordonner en référé toutes les mesures qui ne se heurtent à aucune contestation sérieuse ou que justifie l'existence d'un différend"

184. “Article 809. Le président peut toujours, même en présence d'une contestation sérieuse, prescrire en référé les mesures conservatoires ou de remise en état qui s'imposent, soit pour prévenir un dommage imminent, soit pour faire cesser un trouble manifestement illicite .

"Dans les cas où l'existence de l'obligation n'est pas sérieusement contestable, il peut accorder une provision au créancier, ou ordonner l'exécution de l'obligation même s'il s'agit d'une obligation de faire".

185. Pode soar estranho o instituto do référé prevention que concede a tutela mesmo na existência de uma contestação séria. O que ocorre, na realidade, é uma análise mais profunda do exame do mérito, mesmo a contestação do réu sendo séria o direito apresentado pelo autor merece ser tutelado.

186. "Tuttavia, si commetterebbe un grosso errore ad assimilare i due tipi di référé. Il discrimine tra le due forme di tutela sta nel fumus boni iuris; il référé classique risponde all'archetipo di una tutela urgente, il cui scopo è quello di dare uma risposta immediata ad um stato di crisi conflittuale, senza la possibilità di esaminare il fumus boni iuris, in quanto il potere del giudice si arresta ove, in presenza di uma contestazione seria, ocorra indagare sul diritto controverso; al contrario, il référé 
Inverte-se o ônus do tempo do processo para o réu e evita-se que o autor arque com um dano irreparável.

O référé provision, a grande inovação do Direito francês, é o exemplo mais claro da denominada tutela de evidência: não é necessária a urgência para o deferimento da tutela, bastando que o direito do autor seja evidente e que não haja contestação séria do réu. É igualmente aplicado em todos os tribunais franceses.

O procedimento inicia-se com a propositura da ação. Ocorrendo a citação, o réu é chamado a comparecer em audiência designada, sendo assegurado prazo razoável para que ele elabore sua contestação e apresente defesa - o prazo deve ser fixado pelo juiz. Caso o autor não compareça à audiência, o processo é julgado extinto; caso o réu não compareça, ocorre a revelia.

No caso de comparecimento, o réu apresenta a sua defesa e geralmente já se inicia a fase instrutória naquele momento (em algumas situações é designada uma audiência posterior). O juiz pode requerer a produção de provas de ofício, caso entenda que são essenciais para o deferimento da tutela, mas dificilmente solicitará provas que não sejam compatíveis com o procedimento. Na própria audiência é proferida a decisão, concedendo ou denegando a tutela pleiteada. Trata-se, portanto, de um procedimento oral e altamente concentrado.

A decisão proferida no référé é provisória a priori, podendo estabilizar-se caso as partes não recorram ou não proponham a ação principal. A decisão não adquire força de coisa julgada, e pode ser proposta a ação com o escopo de discutir o mérito, tanto pelo réu quanto pelo autor que desejar uma decisão definitiva. Esse sistema faz com que o réu recorra somente quando tenha certeza de que conseguirá reverter a decisão, o que traz uma enorme satisfatividade com o référé provision.

de prévention o de remise en ètat consente una valutazione di attendibilità anticipata della situazione sostanziale controversa, in modo che, anche in caso di contestazione seria del diritto controverso, il giudice possa prendere les mesures opportune al fine di evitare un danno imminente o il perdurare di um turbativa illecita" (Dino Buoncristiani, Sistema dei référés: tutela cautelare dal pregiudizio e tutela urgente senza pré-giudizio, Rivista Trimestrale di Procedura Civile, n. 2. p. 593). 
Assim, pode-se falar também que tal medida tem a instrumentalidade ${ }^{187}$ mitigada, haja vista que não é obrigatória a propositura de uma ação principal, ${ }^{188}$ a decisão proferida no référé basta para satisfazer as partes.

A decisão pode ser revogada pelo mesmo juiz que a concedeu, desde que haja novas circunstâncias que permitam a reapreciação da matéria.

Quanto à exequibilidade da medida, a decisão constitui um título executivo de pleno direito, permitindo execução imediata com a possibilidade de fixação de astreintes para compelir o réu ao cumprimento da decisão.

Ao contrário das demais espécies de référés que surgiram da criação jurisprudencial, o référé provision surgiu com o Decreto n. 73-1.122, de dezembro de 1973. Primeiramente, foi atribuído apenas ao tribunal de grande instance, estendendose, com a edição do Decreto n. 1.123 em dezembro de 1975, aos tribunais de instance e aos tribunais comerciais. ${ }^{189}$ No Código de Processo Civil francês há vários artigos que regulam a matéria - o art. $809, \S 2^{\circ}$ diz respeito ao référé provision no tribunal de grande instance, e o art. 849, no Tribunal de instance. Eis a redação do art. 809, $\S 2^{\circ}$ : “Dans les cas où l'existence de l'obligation n'est pas sérieusement contestable, il peut accorder une provision au créancier, ou ordonner l'exécution de l'obligation même s'il s'agit d'une obligation de faire".

Da análise do artigo depreende-se que o único requisito para a concessão da tutela é a ausência de uma contestação séria e a consequente evidência do direito da parte autora. Analisaremos mais profundamente esses requisitos.

O âmbito de aplicação do référé provision é amplíssimo, e pode ter por objeto todos os tipos de direito: comercial, do trabalho, agrário, previdenciário etc. Ainda

187. Instrumentalidade aqui entendida como "instrumento do instrumento". Cf. José Roberto dos Santos Bedaque, op. cit., p. 145-146: "Ainda que possam seus efeitos confundir-se com aqueles produzidos pela tutela satisfativa, isso nas hipóteses em que a cautelar os antecipa provisoriamente, o objetivo dessa modalidade de tutela jurisdicional é assegurar a efetividade da outra. Não tem ela um fim em si mesma, pois não é suficiente para eliminar definitivamente a crise verificada no plano das relações materiais. O pronunciamento de natureza cautelar existe em função de outro, este destinado a dar solução ao litígio, aquele com função de assegurar a efetividade do resultado definitivo. Onde houver cautelar haverá, necessariamente, outra tutela. [...] A tutela cautelar está a serviço de outra, a definitiva. Essa relação de instrumentalidade existe em medida de natureza cautelar, mesmo naquelas destinadas a antecipar provisoriamente efeitos do resultado final".

188. Cf. Dino Buoncristiani, Sistema dei référés: tutela cautelare dal pregiudizio e tutela urgente senza pré-giudizio, Rivista Trimestrale di Procedura Civile, n. 2. p. 595: "In nessun caso e per nessuno dei tipi esaminati di référé è previsto l'obbligo di iniziare il giudizio di merito".

189. Para melhor contexto histórico sobre o référé provision ver Alessandro Jommi, Per un'efficace tutela sommaria dei diritti di obbligazione: il référé provision, Rivista de Diritto Civile, ano XLIII, n. 1, p. 121-164. 
pode ser concedido em todos os tribunais, independentemente da natureza da obrigação. Sua origem pode ser legal (prevista no Código), contratual, extracontratual ${ }^{190}$ e mesmo processual, sendo utilizado, nesse último caso, para penalizar abuso do direito de defesa. ${ }^{191}$ Quanto ao objeto do référé, originariamente, somente era permitida a condenação em obrigação de pagar, não sendo permitida a obrigação de fazer e de não fazer. Com o Decreto n. 85-1.130, de dezembro de 1985, foi permitida a possibilidade de obrigação de fazer. No entanto, a obrigação de não fazer ainda é excluída das hipóteses do référé provision. Caso a parte necessite de uma tutela urgente, deverá socorrer-se do référé prevention que é previsto para situações de dano iminente.

O campo de incidência mais comum do référé provision é o da responsabilidade civil, no qual é comum sua aplicação em hipóteses de presunções de direito material, o que torna evidente o direito alegado pela parte autora e dificilmente contestado pelo réu (ausência de contestação séria). Um exemplo desse tipo de situação é o da vítima de um acidente automobilístico.

Em casos de responsabilidade contratual também é possível a aplicação do référé provision, na hipótese de um descumprimento. É possível a concessão da tutela com base no quanto acordado entre as partes no contrato.

A verificação da inexistência de contestação séria ocorre com a análise do mérito da questão e, consequentemente, com a análise da evidência do direito do autor.

O conceito de contestação séria não é facilmente definido pela doutrina, mas, sim, muitas vezes pela jurisprudência, ${ }^{192}$ pois trata-se antes de uma questão analisada caso a caso, que depende das circunstâncias dos casos, das provas apresentadas pelas partes e da valoração das mesmas pelo juiz. Mesmo diante da dificuldade da doutrina em

190. “A tutti i giudici dei référé di primo grado, a qualunque 'giurisdizione' civile esse appartengano, è stato riconosciuto il potere di concedere una provvisione, Nei limiti della loro competenza. Il référé provision può dunque essere domandato in ogni materia: civile, commerciale, di diritto del lavoro, agraria, di previdenza e assistenza sociale.

"A sua volta, la natura dell'obligazione è indifferente; può essere di fonte contrattuale, delittuale o legale" (Alessandro Jommi, Per un'efficace tutela sommaria dei diritti di obbligazione: il référé provision, Rivista de Diritto Civile, ano XLIII, n. 1, p. 125).

191. Aqui, nota-se a correspondência com o art. 273, II do CPC brasileiro, em que a tutela poderá ser concedida em casos de abuso de direito de defesa.

192. "Di creazione giurisprudenziale, poi recepita a livello legislativo questa nozione si ricollega all'antico divieto di 'faire préjudice au principal' (di arrecare pregiudizio al merito della controversia) oggi scomparso dai testi legislativi e con la problemática ad esso connessa" (Alessandro Jommi, Per un'efficace tutela sommaria dei diritti di obbligazione: il référé provision, Rivista de Diritto Civile, ano XLIII, n. 1, p. 127, nota 24). 
apresentar um conceito sobre a "ausência de contestação séria", esta tenta traçar alguns critérios gerais para a aplicação do instituto.

O primeiro critério é que a contestação não se refira somente quanto ao mérito da questão, mas que também, em sede de cognição sumária, não seja infundada. O juiz que, ao analisar a questão em caso de contestação séria, fique em dúvida sobre o direito alegado pelo autor em razão da contestação apresentada pelo réu não poderá conceder a tutela. ${ }^{193}$ Esse primeiro critério está estritamente ligado à evidência do direito alegado pelo autor, daí denominar-se o référé provision o instrumento que proporciona a tutela de evidência por excelência. A análise do direito do autor aplica-se no caso concreto, e cabe ao juiz valorar as questões de direito material, bem como de direito processual com um exame crítico das provas carreadas pelas partes nessa sede de cognição sumária. ${ }^{194}$ Nesse ínterim, é correto afirmar que a contestação do réu somente não será séria quando o direito do autor for evidente.

O segundo critério está ligado à estabilização da decisão proferida no référé provision, já que não pode haver uma declaração do direito, mas somente uma análise do mérito. Esse limite da atuação do juiz ocorre porque a tutela deferida no référé provision é a priori provisória, podendo seguir alguns caminhos: pode ser futuramente revogada pelo próprio juiz, se apresentados fatos novos pelas partes; o réu, contra quem foi concedida a tutela, pode recorrer para modificar a decisão; o autor, que obteve a tutela, pode propor a ação principal, somente para ver declarado o seu direito e obter uma sentença de mérito; as partes se conformam e a decisão deferida em sede de référé se estabiliza.

193. "Si afferma cosi che innanzitutto la contestazione deve (cosi come risulta dall'art. $809 \mathrm{ncpc}$ ) riguardare l'esistenza dell'obbligazione, essere cioè tale se fondata, da estinguere o ridurre l'obbligazione fatta valere e che poi tale contestazione è seria tutte le volte che uno dei mezzi di difesa opposti alla pretesa dell'attore non è manifestamente vano, tutte le volte che - detto altrimenti, esiste una incertezza, per quanto esigua questa possa essere, sul modo cui risolverebbe la questione (di fatto o di diritto) il giudice di merito, se investito della controversia" (Alessandro Jommi, Per un'efficace tutela sommaria dei diritti di obbligazione: il référé provision, Rivista de Diritto Civile, ano XLIII, n. 1, p. 129).

194. "O problema se põe no plano fático, sobre ser evidente ou não o direito demonstrado ao juízo para viabilizar a tutela sumária não cautelar, de satisfatividade plena e por vezes irreversível. Os fatos, como sabido, são levados ao juízo através das provas, razão pela qual, quando se fala em direito evidente, diz-se direito evidenciado ao juízo através das provas. Esse caráter é um misto de atributo material e processual. Sob o ângulo civil, o direito evidente é aquele que se projeta no âmbito do sujeito de direito que postula. Sob o prisma processual, é evidente o direito cuja prova dos fatos sobre os quais incide revela-os incontestáveis ou ao menos impassíveis de contestação séria" (Luiz Fux, op. cit., p. 311). 
Asseveramos que uma das características do référé é a mitigação da instrumentalidade, ou seja, não é necessária a propositura de uma ação principal, pois a decisão se estabiliza. Essa estabilização ocorre somente sobre os fatos, portanto, a decisão nunca adquirirá força de coisa julgada. ${ }^{195}$ Cabe esclarecer que é possível o deferimento de tutela em sede de référé provision mesmo em casos que envolvam questões exclusivamente de Direito. Isso somente é possível em questões já pacíficas na jurisprudência a favor da tese do autor, não podendo existir qualquer interpretação em sentido contrário. Por fim, a ausência de contestação séria aproxima-se do conceito de fumus boni iuris, ${ }^{196}$ ou, especificamente na legislação brasileira, da verossimilhança e da prova inequívoca, uma vez que a análise do direito controvertido é essencial para o deferimento da tutela, principalmente em casos de tutela de evidência.

O sucesso do référé provision na França é inegável. Levando em consideração o crescimento vertiginoso do contencioso e a proliferação de leis que suscitam um número maior de ações no Poder Judiciário, o référé provision foi a solução encontrada pelo legislador francês para prestar jurisdição em um tempo hábil e garantindo o contraditório. Há que se considerar que para o Estado a solução em sede de cognição sumária é financeiramente vantajosa, pois ele gastará menos recursos para a manutenção dos processos, além de entregar a prestação jurisdicional aos cidadãos.

Nota-se que o référé provision, por não ter como requisito a urgência ou a presença de dano irreparável, aumentou o leque de possibilidades de tutelas submetidas ao référé solucionando rapidamente questões que antes demoravam anos para serem

195. Apesar de grande parte da doutrina afirmar que não ocorre a formação de coisa julgada, há uma corrente que afirma que ocorre uma formação de coisa julgada formal, somente sobre os fatos: "Registrou referido autor [René Japiot], entretanto, que, muito embora do ponto de vista jurídico seja provisória a medida, no plano dos fatos é frequentemente definitiva. Isso ocorre na medida em que, frequentemente, a 'ordonnance éclaire a la partie contre laquelle esse es rendue sur la portée de sés droits, et cette partie ne poursuit pas l’affaire plus loin. Ainsi, dans les tribunaux charges, le référé sert à dégager le role d'une foule de petites contestations que tranche en fait l'ordonnance présidentielle" (Ricardo de Barros Leonel, Tutela jurisdicional diferenciada, p. 7071).

196. "Così l'assenza di contestazione seria come limite ai poteri giurisdizionali del giudice dei référés, se - come vedremo - può essere alla fine accostata al nostro fumus boni iuris (per il richiamo alla analogia tra i due istituiti, v. Ricci. Per un'efficace tutela provvisoria ingiuzionale dei diritti di obbligazione, in Rivista di diritto processuale 1990, p. 1029), presuppone un punto di vista fortemente radicato nel timore che il giudice dei référé, il quale statuisce rapidamente nell'ambito di um procedimento sommario, risolva questioni di merito seriamente controverse, sostituendosi completamente al giudice di merito, usurpando il posto occupato dal processo a cognizione piena" (Alessandro Jommi, Per un'efficace tutela sommaria dei diritti di obbligazione: il référé provision, Rivista de Diritto Civile, ano XLIII, n. 1, p. 128, nota 24). 
solucionadas. ${ }^{197}$ Além de ampliar as hipóteses cabíveis em sede de référé, o legislador francês ampliou também os casos de julgamento por um juiz singular, quebrando com a tradição das decisões colegiadas em primeira instância. Ainda, ressalta a doutrina que o référé provision tem um efeito moralizador ao coibir o abuso de direito de defesa, evitando que o devedor não cumpra espontaneamente a obrigação e então diminuindo o tempo do processo.

Claro que existiram críticas ao instituto do référé provision, principalmente por este ser despido do critério da urgência, o que significaria uma sumarização excessiva do processo com violação às garantias constitucionais. ${ }^{198}$ Contudo, essas críticas ocorreram no momento da criação do instituto, e, considerando sua evolução, pode-se constatar que há mais benefícios que prejuízos, pois grande parte das decisões proferidas em sede de référé provision se estabilizam e são cumpridas voluntariamente pela parte devedora, a quem é mais vantajoso cumprir a decisão a recorrer, sem que seja necessária qualquer violação aos princípios constitucionais.

Essa ampliação das hipóteses cabíveis de référé e a consequente prestação jurisdicional mais ágil fez com que os cidadãos voltassem a acreditar na estrutura judiciária do país. O exemplo francês é prova de que não é necessário sacrificar garantias constitucionais (como o contraditório, já que a tutela somente é proferida após a oitiva da parte contrária) para se obter uma tutela jurisdicional ágil; é prova de que é possível conciliar os interesses das partes com a garantia constitucional do contraditório.

$\mathrm{Na}$ Itália há o instituto da condanna con riserva, que permite que a parte autora inicie a execução de uma decisão sem a necessidade de se aguardar a análise profunda e a instrução probatória. Trata-se de um instituto típico previsto em alguns dispositivos

197. “A più di vent'anni dalla sua creazione, il bilancio del référé provision è estremamente positivo. Qualche giurista vi há visto uma delle migliori riforme processuale i degli ultimi anni; e in generale nessuno ne nega l'utilità e i vantaggi. La sua introduzione ha data un nuovo slancio al référé e il ricorso ad esso è stato crescente e prodigioso in ogni ambito, specializzandosi essenzialmente, come si è mostrato, in materia quali la costruzione immobiliare e la responsabilità civile in materia di sinistri stradali, che si caratterizzavano per i lunghi tempi processuali. Ugualmente enorme successo ha avuto davanti alla giurisdizione commerciale, in un'epoca di crisi econômica in ui le imprese trovano tante difficoltà nel recupero dei loro crediti (conviene pagare gli interesse moratori al Tasso legale che ricorrere al prestito delle banche per adempiere subito" (idem, ibidem, p. 159).

198. Alessandro Jommi cita como exemplo o livro de Raymond Martin, Le référé, théâtre d'apparence (idem, ibidem, p. 161). 
legais, dentre eles o art. 1.462 do Código Civil italiano, ${ }^{199}$ que limita as situações em que os réus podem apresentar exceções quando do cumprimento de obrigações contratuais. $\mathrm{O}$ interessante da condanna con riserva é que ela possibilita ao credor satisfazer seu direito de crédito no menor tempo possível, afastando a ideia ultrapassada, diga-se de passagem - de que a fruição do direito e a sua execução somente podem ser alcançadas através do procedimento de cognição plena e exauriente. Há, afinal, a inversão do tempo do processo, o qual, antes exclusivamente suportado pelo autor, passa a ser suportado pelo réu. Logicamente, para o deferimento da tutela é necessário que se trate de um direito evidente e uma exceção infundada. Essa técnica justifica-se apenas se a exceção for provavelmente infundada e para provar o seu fato impeditivo, extintivo ou constitutivo do seu direito o réu deverá prová-lo. Ou seja, durante a instrução probatória o réu carregará o fardo do tempo. ${ }^{200}$ Vale ressaltar também que não basta apenas a evidência do direito do autor, mas a exceção do réu também deve ser provavelmente infundada.

O projeto do novo Código de Processo Civil brasileiro também previu a possibilidade de concessão de liminar na hipótese das tutelas de evidência. Até a conclusão deste trabalho foram discutidas várias versões do projeto apresentado pela comissão de juristas - um projeto muito bom, aliás, considerando-se o exíguo prazo que foi dado aos juristas. Na última versão votada pela Câmara dos Deputados, com a $6^{\mathrm{a}}$ emenda aglutinativa substitutiva global, ${ }^{201}$ a tutela de evidência vem dentro do livro da tutela antecipada, com as subdivisões entre tutela de urgência e tutela de evidência. A crítica a essa nova nomenclatura e divisão do projeto serão feitas no capítulo 6.2 deste trabalho. Por ora, analisaremos como a tutela de evidência foi tratada nessa última emenda.

No parágrafo único do art. 295 há uma disposição autorizando a concessão de tutela antecipada baseada na urgência ou evidência, misturando os dois conceitos de tutela sumária cautelar e não cautelar. As hipóteses de concessão da liminar no caso

199. “Art. 1462. Clausola limitativa della proponibilità di eccezioni. La clausola con cui si stabilisce che una delle parti non può opporre eccezioni al fine di evitare o ritardare la prestazione dovuta, non ha effetto per le eccezioni di nullità (1418 e seguenti), di annullabilità (1425 e seguenti) e di rescissione (1447 e seguenti) del contratto. Nei casi in cui la clausola è efficace, il giudice, se riconosce che concorrono gravi motivi, può tuttavia sospendere la condanna, imponendo, se nel caso, una cauzione (att. 167; Cod. Proc. Civ.1 19)".

200. Luiz Guilherme Marinoni, Tutela antecipatória e julgamento antecipado: parte incontroversa da demanda, p. 47.

201. O texto legal está no Anexo II. 
de tutela de evidência estão prescritas no art. 306, e sua principal característica é a ausência de "demonstração de perigo da demora da prestação da tutela jurisdicional". Além desse critério, deverá ser demonstrado que: há abuso do direito de defesa ou manifesto propósito protelatório do réu; os fatos alegados pelo autor estão documentalmente comprovados; já há tese repetitiva formada ou baseada em súmula vinculante. Por fim, o inciso III do projeto ainda prevê a seguinte situação: "se tratar de pedido reipersecutório fundado em prova documental adequada do contrato de depósito, caso em que será decretada a ordem de entrega do objeto custodiado, sob cominação de multa". 202

Analisando essa nova redação, notamos que o legislador entendeu bem que a tutela de evidência é uma tutela sumária não cautelar, pois o requisito da urgência não é requerido. No entanto, o legislador nada diz a respeito da possibilidade de estabilização dessa decisão, hipótese que era prevista no anteprojeto entregue ao Senado pela comissão de juristas. Não prever essa hipótese é um retrocesso ao nosso sistema processual vigente.

\subsubsection{Outros procedimentos de cognição sumária}

Trataremos agora de outros procedimentos de cognição sumária, sem que haja polêmica quanto à possibilidade de estabilização e outorga da força de coisa julgada por opção legislativa. São eles: a monitória, cujo estudo é essencial apesar de ter sido excluída no projeto do novo Código de Processo Civil; as ações possessórias; os embargos de terceiro; a consignação em pagamento; o mandado de segurança.

Trataremos brevemente de cada uma das principais características desses procedimentos, sempre sob a perspectiva da sumariedade da cognição e da possibilidade de estabilização da tutela.

202. Ver Anexo II. 
Trata-se de modalidade de tutela diferenciada, ${ }^{203}$ ou seja, de cognição sumária, em que as fases do procedimento de conhecimento são dispensadas em um primeiro momento e não há contraditório. O juiz poderá deferir medida mandamental, em caso de inexistência de contestação, e essa decisão mandamental pode se converter em título executivo judicial. ${ }^{204}$

A natureza do procedimento monitório é tema de estudo de diversos doutrinadores que discutem se seria um processo de conhecimento ou um processo de execução, haja vista a peculiaridade do procedimento. Entendemos que é um procedimento de conhecimento que, após dada a oportunidade de o réu se manifestar e julgada a ação forma-se o título executivo. ${ }^{205} \mathrm{O}$ mandado monitório é expedido somente se o réu não apresentar embargos que se torna um título executivo; antes disso ele não possui essa força executiva. No entanto, essa é uma discussão que não será aprofundada aqui, pois

203. "Il procedimento,come molti altri del nostro ordinamento, si colloca in una categoria di processo di cognizione diversi da quelli ordinari e speciali a cognizione piena. Mentre il processo ordinario di cognizione, così com il processo che si svolge secondo il rito speciale del lavoro, realizzano pienamente il contraddittorio in forma anticipata rispetto alla decisione, prevedono articolate e complesse attività sia nelle forme che nei termini, si concludono con una sentenza il cui accertamento, in essa contenuto, è destinato ad assumere una particolare incontrovertibilità o immutabilità, nell'ambito dei processo a cognizione sommaria invece, il legislatore deroga, in tutto o in parte, a questi criteri e previsioni" (Luigi Paolo Comoglio; Corrado Ferri; Michele Taruffo, op. cit., p. 469).

204. Salvatore Satta assim definiu il procedimento di ingiunzione: "il procedimento di ingiunzione è una forma speciale dell'ordinario processo di condanna. La sua specialità consiste in questo: che all'accertamento (contenzioso: supra, parte II, n. 2) è sostituita una cognizione sommaria e non contradittoria, che mette capo a un decreto, suscettibile di opposizione da parte del debitore" (Salvatore Satta, Diritto Processuale Civile, p. 496).

205. "Como um tertium genus, o procedimento monitório inerente a essa ação reporta-se, na visão de Carnelutti, a um tipo de processo cuja estrutura peculiar decorre de função diversa daqueles atinentes ao processo de conhecimento e de execução. Humberto Theodoro Júnior adotou esse posicionamento, qualificando-o como um procedimento intermediário, ao lado do processo de execução e daquele de conhecimento, 'de larga aplicação prática e de reconhecida eficácia para abreviar a solução de inúmeros litígios.' Da mesma forma, Chiovenda o considerou um procedimento específico, gerador de sentença de prevalente função executiva, ao lado de outros procedimentos com idêntico escopo. Entretanto, não o descartou da área do processo de conhecimento. Deveras é nesta que o procedimento monitório encontra sua adequada colocação. Ainda que a cognição do Juízo, na hipótese de revelia do réu, cinja-se à admissibilidade da via injuncional e à plausibilidade do direito nela invocado, existe a atividade cognoscitiva e é ela pressuposto do acesso à via executiva, através do título executivo nela formado. $\mathrm{O}$ processo de execução emerge do resultado da ação monitória, que inexoravelmente o antecede para a formação do título executivo judicial, mas com ela não se confunde, até porque pode não ser incoado 'ex officio', pois tal resta ao alvedrio do credor. Ora, se o procedimento monitório decorrente da propositura de ação dessa natureza é, por si só, hábil a gerar um título executivo judicial, sua função, exaurindo-se com esse resultado, demonstra a sua autonomia em face do processo de execução, o que significa não se confundir com este" (Donaldo Armelin, Apontamentos sobre a ação monitória: Lei 9.079.1995, Revista do Instituto de Pesquisas e Estudos, n. 14, p. 30-31). 
nosso foco é tratar da cognição sumária das tutelas diferenciadas. E nesse sentido não há dúvida de que se trata de uma tutela diferenciada.

Segundo Proto Pisani, ${ }^{206}$ uma das justificativas para a existência do processo monitório (ingiuntivo) é evitar o custo do processo de cognição plena, porque o autor já possui um título que comprova o seu direito e não haveria a necessidade de se instaurar um contraditório prima facie. ${ }^{207}$ Cabe à própria parte a instauração do contraditório e ao juiz o acolhimento dos argumentos do réu caso esse entenda que é a situação dos autos. O contraditório só ocorre em um segundo momento (secundum eventum defensionis), ${ }^{208}$ e primeiramente é proferido o despacho mandamental. ${ }^{209} \mathrm{Ou}$ seja, há sumarização tanto da cognição quanto do procedimento, uma vez que a cognição está limitada a verificar os requisitos da monitória, a saber: se possui prova escrita, que não tenha eficácia de título executivo e que o pedido seja o recebimento de soma em dinheiro ou entrega de bem móvel determinado ou coisa fungível.

O primeiro ato judicial parte de uma presunção baseada exclusivamente na prova documental trazida pelo autor de que este é titular do direito, por esse motivo é possível já determinar o pagamento da quantia buscada em juízo. No entanto, por não ter força de título executivo não é possível determinar os atos constritivos de imediato, é necessário aguardar a manifestação do réu para somente depois serem praticados tais atos. O contraditório é instaurado pelo réu, que se vê na posição de interessado (ao contraditório do procedimento ordinário em que o contraditório é instaurado pelo autor).

No procedimento monitório, a cognição exauriente ocorre apenas se for apresentada a defesa, ou seja, secundum eventum defensionis. A tutela monitória é cabível naquelas situações em que exista uma dívida líquida, certa e exigível, mas não

206. Andrea Proto Pisani, La tutela sommaria in generale e il procedimento per ingiunzione nell'ordinamento italiano, Revista de Processo, vol. 23, n. 90, p. 22-35.

207. "La ragione che giustifica questo procedimento sta in ciò: che presumibilmente il debitore non ha nulla da opporre contro la pretesa del creditore, e quindi si rivela inutile il complesso mecanismo del processo ordinario" (Salvatore Satta, Diritto processuale civile, p. 496).

208. Donaldo Armelin, Ainda o procedimento monitório, Revista da Escola Paulista da Magistratura, 1998.

209. "Il decreto ingiuntivo è una pronuncia di condanna che il giudice emette a conclusione di un procedimento speciale e a seguito di cognizione sommaria, in totale assenza di contraddittorio. È prevista tuttavia una seconda fase del processo la cui iniziativa è attribuita al debitore ingiunto e che consiste nella proposizione della opposizione al decreto, con l'instaurazione di in giudizio ordinario di cognizione che si svolge con ogni garanzia di contraddittorio, pertanto differito rispetto alla fase iniziale, giudizio che se si conclude con una sentenza di accoglimento ha efficacia sostitutiva del decreto stesso" (Luigi Paolo Comoglio; Corrado Ferri; Michele Taruffo, op. cit., p. 469). 
haja título, ou o título não esteja previsto no rol legal. Deverá o autor apresentar prova escrita, ${ }^{210}$ geralmente assinada pelo próprio devedor, bem como juntar as outras provas pertinentes para a análise sumária do juiz. A ação monitória tem sempre por objeto a cobrança de um valor certo e determinado em um documento (não título executivo), mas nunca deve ser uma obrigação ou qualquer outro pedido que se encaixe em um procedimento de cognição plena e exauriente (como ação de indenização baseada na responsabilidade civil). ${ }^{211}$

Interessante notar ainda que o legislador escolheu a locução "prova escrita" e não “documento escrito". Como alerta Talamini, a locução prova tem significado mais amplo que documento, carregando em si três significados distindos: 1) meio empregado para a descoberta do fato; 2) prova como atividade jurisdicional; 3 ) prova como resultado em que o juiz exerce a sua cognição, ainda que sumária. ${ }^{212}$

Sobre esses documentos que o julgador analisará se é possível deferir ou não a decisão ordenando o pagamento de soma em dinheiro, entrega de bem fungível ou determinado imóvel, conforme prevê expressamente o art. 1.102 do CPC. ${ }^{213,214}$ Uma das características da tutela monitória é romper com a ideia de nulla executio sine titulo. Como autoriza o dispositivo legal mencionado, caso a monitória não seja

210. O dispositivo legal determinou que fosse juntada prova escrita, ou seja, o crédito deve ser comprovado inicialmente apenas por meio de documento escrito e não de prova audiovisual. Isso se justifica em razão da limitação da cognição que será realizada nessa primeira etapa. Basta que o juiz se convença de que o valor é devido e saiba o quantum - outros detalhes não são necessários.

211. Antonio Maria Lorca Navarrete escreve sobre o tema, delimitando que a ação monitória deve apenas cobrar um valor exato: "Por ello, la doctrina admite, por lo general, la exclusión del procedimiento monitorio, de todas las acciones por resarcimento de daños, aún cuando la demanda tenga como fundamento la responsabilidad contractual del deudor. En consecuencia, el derecho de crédito debiera reunir las siguientes características: a) ha de se exigible; b) ha de tener por objeto una suma de dinero; c) que la suma de dinero sea líquida y determinada" (Antonio Maria Lorca Navarrete, El procedimiento monitorio civil, p. 46).

212. Eduardo Talamini, Tutela monitória: a ação monitória - Lei 9.079/95, p. 72.

213. "Art. 1.102.a - A ação monitória compete a quem pretender, com base em prova escrita sem eficácia de título executivo, pagamento de soma em dinheiro, entrega de coisa fungível ou de determinado bem móvel".

214. No direito estrangeiro são previstas outras possibilidades de ação monitória. Na Itália como aponta Comoglio, Ferri e Taruffo: "Il diritto di credito di una somma di denaro liquida ossia determinata nel su ammontare, ed è quindi escluso il danno da svalutazione proprio per il difetto di liquidità. Il credito può avere ad oggetto anche la consegna di un bene mobile determinato (escluso quindi il diritto al rilascio di cose immobili). Infine, 44 il diritto alla consegna di una 'determinata quantità di cose fungibili'; in questo caso tuttavia (v. art. 639) il ricorrente deve dichiarare la somma di denaro che, in alternativa, è disposto ad accettare in mancanza della prestazione in natura. Da un lato dunque il debtore può liberarsi versando la somma richiesta dal creditore e dall'altro quest'ultimo, ottenuto il decreto ingiuntivo, potrà procedere in tuttavi come la mancata indicazione della somma non comporti affatto la nullità del decreto riducendo l'effetto all'esecuzione per consegna delle cose dovute" (Luigi Paolo Comoglio; Corrado Ferri; Michele Taruffo, op. cit., p. 473). 
embargada, ela se transforma em título executivo sem a necessidade de haver um título e haver o contraditório.

É utilizada como prova documental aquela que seja escrita, excluindo-se fotografias, fitas etc. A prova apresentada pelo autor deve ser suficiente para conferir um grau de probabilidade ao juiz; obviamente, não é necessário que a prova prove um direito líquido e certo, como no mandado de segurança, mas ela deve proporcionar essa certeza ao juiz para que ele, em sede de cognição sumária, possa determinar a expedição do mandado monitório.

O documento que serve como prova escrita deve ter esse grau de probabilidade suficiente para convencer o juiz, mas não necessariamente para autorizar uma execução de título (se assim fosse, ela seria uma execução e não uma monitória). Também não é necessária a certeza que advém da prolação de uma sentença em um processo de conhecimento, porque a tutela monitória está entre a tutela executiva e a de cognição plena, mas sempre será uma tutela cognitiva, ainda que sumária. ${ }^{215}$

No direito brasileiro, com a apresentação dos embargos monitórios a cognição passa a ser plena, porque o processo se desenvolve plenamente com o contraditório e a produção de provas, na qual o juiz poderá formar a sua convicção plena sobre os fatos. Um dos requisitos da prova escrita é que ela contenha o valor líquido e certo que será cobrado do devedor, já que não faz muito sentido exigir do devedor um valor ilíquido e que tenha de ser apurado em processo, pois após o decurso do prazo para apresentação de embargos o mandado monitório se converte em mandado de execução, assimilando os requisitos deste.

Além disso, se do documento não é possível extrair o quantum debeatur, seria necessária a propositura de uma ação de cognição plena para que em eventual perícia se chegasse ao valor correto. Ou seja, o documento não é o adequado para instruir a ação monitória. Assim, Tucci afirma que "dos três requisitos clássicos que conotam o título executivo, o título injuntivo (prova escrita) ostenta apenas dois - exigibilidade e liquidez -, uma vez que a certeza será agregada ao documento pela decisão judicial que determina o pagamento ou a entrega da coisa". 216

É importante ter em mente que a técnica adotada por nossa legislação processual obriga ainda dois fatores (além dos exigidos em lei), típicos do nosso sistema: o

215. José Rogério Cruz e Tucci, Ação monitória: Lei 9.079 de 14.7.1995, p. 84.

216. Idem, ibidem, p. 87. 
convencimento do juiz sobre a prova ali trazida na inicial e a consequente presunção de veracidade dos fatos declinados na inicial. Ou seja, o ônus de provar ainda continua com o autor. Nada muda o fato de o réu não apresentar embargos, o que ocorrerá em um momento posterior, haja vista a cognição sumária para a prolação da medida liminar ocorrer no início do processo, quando ainda nem iniciado o contraditório. É a primeira análise do juiz. ${ }^{217}$

Pode o réu contestar a ação no prazo legal de quinze dias, apresentando embargos. Caso ele apresente a defesa, a monitória ficará suspensa até o julgamento final dos embargos. Caso não seja oferecida a defesa ou o réu concorde com o pleito, a decisão mandamental converte-se em título judicial, iniciando-se a execução. ${ }^{218}$ Interessante notar que o mandado de pagamento inicialmente expedido tem força executiva imediata, mas provisória, já que se forem apresentados os embargos monitórios ele será suspenso. Por outro lado, se não forem apresentados os embargos monitórios, o mandado converte-se em título judicial pleno. No entanto, se os embargos forem julgados improcedentes, o mandado restabelece a sua força executiva, agora de maneira plena. ${ }^{219}$

A decisão que ordena a injunção é um provimento sumário satisfativo e autônomo, em que há terminalidade da resposta jurisdicional sem que haja coisa julgada e que encerra a fase sumária de conhecimento do procedimento monitório. ${ }^{220}$

Existem, portanto, dois procedimentos: o primeiro é o de cognição sumária, em que é deferido o mandado injuncional; o segundo, se o réu opuser embargos, é um procedimento incidental ordinário em que são discutidas todas as questões de mérito. O réu tem três possibilidades:

Concordar com a pretensão e cumprir o mandado injuncional; o processo será extinto, não sendo o réu condenado em custas ou honorários advocatícios.

217. Donaldo Armelin, Apontamentos sobre a ação monitória: lei 9.079.1995, Revista do Instituto de Pesquisas e Estudos, n. 14, p. 47.

218. Interessante notar que o título executivo se forma logo após a decisão. Em nenhum momento o dispositivo legal afirma que é necessário o trânsito em julgado. Portanto, a execução inicia-se logo após a prolação da decisão.

219. “Art. 1.102.a - A ação monitória compete a quem pretender, com base em prova escrita sem eficácia de título executivo, pagamento de soma em dinheiro, entrega de coisa fungível ou de determinado bem móvel. [...] $\S 3^{\circ}$ - Rejeitados os embargos, constituir-se-á, de pleno direito, o título executivo judicial, intimando-se o devedor e prosseguindo-se na forma prevista no Livro I, Título VIII, Capítulo X, desta Lei”.

220. Rogério Aguiar Munhoz Soares, op. cit., p. 198. 
Apresentar embargos e alegar defesa de todo o valor cobrado ou de parte do valor executado. A parte que não foi embargada continua a execução normalmente, pois a lei afirma que, apresentados os embargos, a execução se suspende, sendo possível antecipar a tutela conforme o art. 273 do CPC;

Ser revel. O mandado injuncional converte-se então em título executivo, iniciando-se a execução definitiva, conforme o livro II da lei processual, e assegurando-se o direito de opor embargos à execução.

A dúvida que permanece é se há coisa julgada nessa decisão. ${ }^{221}$ Sobre o tema, posicionam-se Comoglio, Ferri e Taruffo:

È anche vero tuttavia che no si può attribuire al decreto ingiuntivo l'efficacia propria del giudicato sostanziale, la quale consegue ai provvedimenti conclusivi di un processo a cognizione piena idoneo a produrre l'accertamento che 'fa stato' descritto nell'art. 2909 c.c., e non sembra assistere l'efficacia del decreto ingiuntivo emesso a seguito di una cognizione sommaria. Le differenze si indicano non solo nell'escludere l'attitudine del decreto a mutare i termini di prescrizione ex. Art. 2953, ma, con riferimento all'oggetto dell'accetamento, la definitiva efficacia esecutiva del decreto non opposto o non validamente opposto non impedisce al debitore, in successivi eventuali processi, di contestare ad ogni effetto diverso dal credito oggetto del decreto ingiuntivo e quid dalla condanna al pagamento e con riferimento al rapporto sostanziale tra le parti; né impedisce qualsiasi altra contestazione rispetto a rapporti dipendenti o connessi con quelli dedotti in giudizio. 222

E por que referida decisão não transitaria em julgado, se foi dada a oportunidade de a parte se manifestar, apresentar defesa e ela simplesmente não o fez? $O$ procedimiento di ingiunzione italiano tem uma estrutura diferenciada (típica) que garante à parte poder se defender, entendendo que se ela não o fez é porque não tinha interesse. Dessa forma, a eficácia da coisa julgada no decreto di ingiunzione está sujeita ao preenchimento de condições especificadas em lei. Se forem preenchidas todas as condições, não há por que não ser outorgado status de coisa julgada à decisão, pois o raciocínio é o mesmo para o procedimento ordinário. A coisa julgada também é atribuída somente se forem cumpridos todos os requisitos exigidos em lei. ${ }^{223}$

221. A dúvida sobre a coisa julgada não é exclusiva do procedimento monitório, mas de todos os tipos de tutela diferenciada. Certamente a decisão se estabiliza, mas até onde vai essa estabilização? Ela confere poder de coisa julgada? Traz segurança jurídica? É possível rescindi-la? Essas questões são tratadas no quinto capítulo deste trabalho.

222. Luigi Paolo Comoglio; Corrado Ferri; Michele Taruffo, op. cit., p. 488. José Rogério Cruz e Tucci (Ação monitória: Lei 9.079 de 14.7.1995, p. 47) afirma que Valiutti e De Stefano reconhecem uma "natureza de um accertamento con attitudine al giudicato, em tudo idêntico àquele contido em uma sentença definitiva de condenação emitida ao final de um procedimento comum de cognição".

223. José Rogério Cruz e Tucci, op. cit., p. 48. 
Tucci, ainda discorrendo sobre o procedimento di ingiunzione italiano, alerta que essa possibilidade de conferir status de coisa julgada à decisão liminar proferida na monitória não é unânime na Itália. Para Giovanni Tomei, ocorre apenas uma preclusão endoprocessual que não permite que o réu impugne o título e a decisão e essa impossibilidade de impugnação não caracteriza a coisa julgada. ${ }^{224}$ Contudo, ainda é assegurado ao réu a possibilidade de ajuizar uma ação autônoma - plena e exauriente - discutindo a natureza do título e do valor cobrado.

Salvatore Satta aponta ainda três situações distintas para a natureza da impugnação apresentada no processo monitório italiano. Seria necessário estabelecer o efeito da extinção do processo em relação ao mandado monitório; se a extinção do processo também considerasse nulo o mandado monitório, estaríamos diante de uma decisão de procedimento ordinário em que o mandado monitório seria resolvido. Caso o mandado monitório fosse definitivo, estaríamos diante de uma simples impugnação. Mas, ao contrário, se os efeitos da extinção fossem limitados ao processo de impugnação, não tocassem o mandado monitório e não impedisse a propositura de uma nova ação ordinária, estaríamos diante de juízo normal de primeiro grau em que o decreto monitório guarda a sua autonomia. ${ }^{225}$

O sistema monitório brasileiro foi duramente criticado por Proto Pisani, categórico ao afirmar que existem várias lacunas na previsão legal e que poderia ser aproveitada a experiência do direito estrangeiro. ${ }^{226}$ Realmente, o sistema monitório italiano é muito mais complexo do que o nosso e parece ser muito utilizado naquele país.

Primeiramente, existem dois tipos de procedimento: o documental e o puro.

224. " "...] finché si accetta l'autonomia delle azioni sommarie ed esecutive, e il rapporto sostanziale (causale o fondamentale) non viene coinvolto, attraverso una formae domanda, nel contraddittorio e nel giudizio, bisogna a nostro avviso rinunciare all'effetto sostanziale di cosa giudicata, perché l'unico effetto finale che pu'derivare dall'esercizio di azioni puramente processuali è la prelucisone dei poteri processuale d'impugnazione, e cioè l'irrevocabilità ed inoppugnabilità dell'atto conclusivo, senza che essa possa espandersi ulteriormente e venire ad incidere sulla realtà sostanziale del rapporto controverso" (Giovanni Tomei, Cosa giudicata o preclusione nei processi sumari ed esecutivi, in: Scritti in onore di Elio Fazzalari, vol. 2, p. 318, apud José Rogério Cruz e Tucci, op. cit., p. 50.

225. Salvatore Satta, Diritto Processuale Civile, p. 503.

226. Andrea Proto Pisani, La tutela sommaria in generale e il procedimento per ingiunzione nell'ordinamento italiano, Revista de Processo, vol. 23, n. 90, p. 22-35. 
O procedimento monitório documental (procedimento di ingiunzione) baseia-se em prova documental incontestável do crédito perseguido. ${ }^{227}$ É previsto no art. 633 do Codice di Procedura Civile. ${ }^{228}$ Trata-se de procedimento específico em que o réu é condenado a pagar uma quantia, a entregar uma coisa determinada ou uma coisa móvel determinada, quando o crédito está comprovado através de prova documental escrita ou previsto em uma categoria específica (em caso de lei especial, se preencher os requisitos documentais específicos).

Já o procedimento monitório puro não requer comprovação escrita da existência do crédito. Eis o teor do art. 186 bis introduzido na reforma de 1990:

\begin{abstract}
Su istanza di parte il giudice istruttore può disporre, prima della remissione della causa al collegio a norma dell'articolo 189, il pagamento delle somme non contestate dalle parti costituite. 'ordinanza costituisce titolo esecutivo e conserva la sua efficacia in caso di estinzione del processo. L'ordinanza è soggetta alla disciplina delle ordinanze revocabili di cui agli articoli 177 primo e secondo comma e 178 primo comma.
\end{abstract}

O dispositivo legal acima é claro ao dar força de título executivo extrajudicial a uma soma não contestada. Esse dispositivo legal introduz uma tutela injuncional (monitória) para uma obrigação pecuniária e também para uma obrigação não pecuniária. Trata-se de mais um reforço para a tutela injuncional italiana, dessa vez previsto no procedimento ordinário. ${ }^{229} \mathrm{~A}$ Itália introduziu a tutela monitória no próprio processo ordinário, ou seja, dentro do processo de cognição aprofundada, quando já se

227. Sobre o processo monitório italiano, ver a opinião de Lotario Dittrichi sobre a especialidade do procedimento e a sua independência: "Il processo d'ingiunzione appare inoltre il prototipo di un procedimento cui non è funzionale l'esistenza necessaria di una fase, anteriore al processo di merito, a cognizione piena: il procedimento montorio appare como tendenzialmente alternativo alla cognizione piena piuttosto che a quest'ultima collegata da un nesso necessario" (Lotario Dittrichi, Dalla tutela cautelare anticipatoria alla tutela sommaria definitiva, Rivista di Diritto Processuale, ano XLIII, n. 3, p. 672-705.

228. "Art. 633. Su domanda di chi è creditore di una somma liquida di danaro o di una determinata quantità di cose fungibili, o di chi ha diritto alla consegna di una cosa mobile determinata, il giudice competente pronuncia ingiunzione di pagamento o di consegna: 1) se del diritto fatto valere si dà prova scritta; 2) se il credito riguarda onorari per prestazioni giudiziali o stragiudiziali o rimborso di spese fatte da avvocati, procuratori, cancellieri, ufficiali giudiziari o da chiunque altro ha prestato la sua opera in occasione di un processo; 3 ) se il credito riguarda onorari, diritti o rimborsi spettanti ai notai a norma della loro legge professionale, oppure ad altri esercenti una libera professione $\mathrm{o}$ arte, per la quale esiste una tariffa legalmente approvata. L'ingiunzione può essere pronunciata anche se il diritto dipende da una controprestazione o da una condizione, purché il ricorrente offra elementi atti a far presumere l'adempimento della controprestazione o l'avveramento della condizione".

229. Edoardo F. Ricci, Per una efficace tutela provvisoria ingiunzionale dei diritti di obbligazione nell'ordinario processo civile, Rivista di Diritto Processuale, ano XLV, n. 4, p. 1021-1036. 
mostrava totalmente necessária para a realidade daquele país durante a década de 1990. Edoardo Ricci justifica a introdução do sistema monitório no procedimento ordinário por razões de economia e equilíbrio.

$\mathrm{Na}$ Itália, na Bélgica e na Alemanha ${ }^{230}$ é adotado o procedimento monitório documental que, como dito, exige prova documental incontestável para a emissão da decisão inicial depois de analisada a inicial, em cognição sumária, e preenchidos os requisitos mínimos.

O Mahnverfahren, processo monitório alemão, é um processo judicial inicialmente conduzido por um auxiliar do juiz, que apenas verifica requisitos formais para a expedição do mandado monitório. Quando o réu apresenta impugnação no Mahnverfahren, acaba tornando sem efeito o mandado de pagamento, transformandoo em simples citação e a partir de então inicia-se um procedimento de cognição plena e exauriente.

Isso não ocorre nos sistemas belga e italiano. Caso o réu apresente impugnação, os efeitos executivos do mandado monitório restam apenas suspensos. Ou seja, se ao final da cognição judicial os embargos monitórios forem rejeitados, a decisão consubstanciada no mandado monitório volta a ter eficácia, transitando em julgado e adquirindo eficácia executiva definitiva.

Em contrapartida, no ordenamento alemão, caso o mandado monitório perca sua eficácia executiva e torne-se somente uma simples citação, se os embargos opostos pelo devedor forem rejeitados, o mandado de pagamento não restabelece seus efeitos, mas a sentença que se transforma em título executivo de natureza condenatória. ${ }^{231}$

Em 2008, na França, ainda foi introduzido o injonction de payer, que se assemelha à lógica germânica da monitória de um processo documental de uma fase única. Para o autor utilizar o injonction de payer é necessário que ele tenha um crédito não satisfeito, líquido e que seja resultante de uma obrigação baseada em contrato (até mesmo cláusula penal), um título de crédito com endosso ou até mesmo um instrumento de cessão de crédito. A técnica consiste em obter um título executivo

230. "L'ingiunzione di pagamento in Germania è uno strumento per arrivare alla rapida esecuzione dei crediti pecuniari. Detto procedimento non richiede l'allegazione di prove documentali e neppure una giustificazione del credito. Il procedimento in esame si fonda, in sostanza, sulla possibilità del debitore di proporre opposizione. Esso risulta pertanto particolarmente efficace, dal momento che vi si può fare ricorso anche nei confronti di debitori residenti o domiciliati all'estero" (Livia di Cola, L'efficacia dei provvedimenti sommari nell'ordinamento tedesco, in: Antonio Carratta (org.), op. cit.).

231. José Rogério Cruz e Tucci, op. cit., p. 57. 
através da inversion du contentieux. Assim a demanda é distribuída, o mandado de pagamento é expedido imediatamente, e a inicial deve conter o pedido e a causa de pedir.

Cruz e Tucci, citando Manuel Serra Domíngues, afirmam que a experiência do processo monitório pode ter sido diferente da experiência brasileira em razão da diferença de mentalidade entre os brasileiros e os europeus. ${ }^{232}$

Em Portugal, foi adotado o procedimento de injunção, introduzido pelo DecretoLei n. 404, de dezembro de 1993. O procedimento aplica-se somente às causas de menor valor e, assim que a ação é protocolada, antes mesmo de ser distribuída ao juiz competente, o funcionário do tribunal expede uma notificação ao requerido sem qualquer intervenção judicial. É aconselhável que o autor junte à inicial o documento que comprove o seu crédito; contudo, esta não é uma imposição legal, pois o eventual documento será analisado apenas se o réu se opuser.

Caso o réu não apresente qualquer tipo de impugnação, ocorre a aposição: o próprio funcionário do tribunal emite um novo mandado, desta vez com a ordem de execução.

Interessante notar que em nenhum momento há qualquer atividade jurisdicional, somente um procedimento extrajudicial, de modo que não há conflito algum entre as garantias constitucionais (efetividade e segurança jurídica), pois até aí o procedimento é extrajudicial. A partir do momento que o réu apresentar oposição, os autos são imediatamente distribuídos ao juízo competente e passarão a ter atuação jurisdicional. $^{233}$

232. "Provavelmente pela mentalidade e cultura do povo europeu, bem é de ver que a técnica da ação monitória tem se mostrado muito profícua no Velho Continente. Assevera, nesse sentido, Manuel Serra Domínguez: 'Mientras en Alemania el juicio monitorio está funcionando con excelentes resultados, en gran parte determinados por el ragmatismo de los uristas alemanes; y en Francia la institución se encuentra en clara progresión; en Italia la defetuosa estructura de la organización judicial ha determinado que aun siendo importante la utilización de juicio monitorio o se haya elevado todavía dicho procedimiento a un primer plano, pese a lo cual su utilidad es reconocida por todos los juristas.' Ademais, os dados estatísticos atualizados, inventariados por Correa Delcaso, atestam efetivamente o êxito do instituto: na Alemanha, a média de oposição tem sido de apenas 10\%; em França esse percentual é ainda menor (5\%); e na Itália, o número de resistência do demandado no âmbito do procedimento de injunão se situa entre 5\% e 10\%" (José Rogério Cruz e Tucci, Ação monitória no novo processo civil português e espanhol, Revista de Processo, vol. 26, n. 103, p. 108-121.

233. “Art. 6 6 - 2 - Sendo deduzida oposição, ou frustrando-se a notificação por via postal, o secretário judicial do tribunal apresentará os autos à distribuição, sendo conclusos ao juiz, o qual, se o estado do processo o permitir, designará, desde logo, o dia para julgamento, observando-se a tramitação estabelecida para o processo sumaríssimo". 
$\mathrm{Na}$ Espanha foi adotado o mesmo procedimento injuncional, conforme os arts. 810-816 da Ley de Enjuiciamineto Civil. Como no procedimento português, somente é aplicável para processos que envolvam um valor monetário baixo, e também há uma fase extrajudicial anterior, já que o credor notifica o devedor requerendo o adimplemento do crédito. Ao contrário do procedimento português, no espanhol foi adotado o procedimento monitório documental, e é imprescindível a juntada de documento (inclusive digital, por exemplo, um e-mail) que comprove o crédito, ${ }^{234} \mathrm{o}$ qual deve ser assinado pelo devedor ou, se não, ao menos comprovar a real negociação entre as partes. Não é necessária a presença de um advogado, bastando apenas o preenchimento de um formulário em que devem constar a origem do débito e o requerimento de pagamento. ${ }^{235}$

O réu tem o prazo de vinte dias para providenciar o pagamento, feito diretamente ao credor ou depositado em juízo, ou oferecer oposição oral ou escrita que dará início a um processo. Transcorrido o prazo de vinte dias, caso o réu não tenha oferecido oposição ou realizado o pagamento, será proferida pelo juiz uma decisão que constitui um título judicial, implicando coisa julgada. O fato de essa decisão possuir força de coisa julgada é muito importante, pois impede que o autor ajuíze nova ação, seja ela de conhecimento ou monitória, e que o devedor discuta o débito, fazendo correr juros moratórios. Caso o réu ofereça contestação, inicia-se um processo de cognição verbal ou ordinário, dependendo do valor da causa. ${ }^{236}$

234. “Altro aspettemerge poi dalla norma: la specialità. Non tutti i diritti soggettivi possono trovare tutela nel processo monitorio, deve trattarsi al contrario di un credito relativo a somme di denaro, credito che, inoltre, deve essere scaduto, ossia deve essere trascorso il termine per l'adempimento, ed esigibile, ovvero non deve dipendere da controprestazioni o condizioni" (Fabio Cossignani, Il processo monitorio spagnolo: un processo sommario-plenario, in: Antonio Carratta (org.), op. cit.).

235. Fabio Cossignani tratando sobre o procedimento monitório espanhol explica que a razão de tal simplificação: "Si persegue in questa maniera un obiettivo di semplificazione della procedura, cui è coerente anche la disposizione secondo la quale è necessario per la presentazione della petición il ricorso all'assistenza di un procurador o di un abogado. In ogni caso il credito che si reclama dovrà, per un verso, essere esigibile e scaduto e, per altro verso, avere a oggetto la consegna di una determinata somma di denaro non superiore a 30.000 euros, purché come prova dello stesso si offra almeno uno dei documenti elencati - in maniera non tassativa - dall'art. 812 LEC" (idem, ibidem).

236. Exposición de motivos de la LEC: En síntesis, este procedimiento se inicia mediante solicitud, para la que pueden emplearse impresos o formularios, dirigida al juzgado de primera instancia del domicilio del deudor, sin necesidad de intervención de procurador y abogado. Punto clave de este proceso es que con la solicitud se aporten documentos de los que resulte una base de buena apariencia jurídica de la deuda. La ley establece casos generales y otro concretos o típicos. Es de señalar que la eficacia de los documentos en el proceso monitorio se complementa armónicamente con el reforzamiento de la eficacia de los genuinos titulos ejecutivos extrajudiciales. Si se trata de los documentos que la ley misma considera base de aquella apariencia o si el tribunal así lo entiende, quien aparezca como deudor es inmediatamente colocado ante a opción de pagar o dar 
Na Inglaterra, país de tradição anglo-saxã, a lógica é outra: o procedimento não é tão formal e baseia-se em uma reforma de 1999, com o Civil Procedure Rules, também conhecido como Woolf's Reform, em que foi introduzida uma série de mudanças administrativas, correspondentes a practice directions, para serem utilizadas por várias cortes. O sistema anglo-saxão de pre-trial e trial já divide o processo em duas fases. A primeira é uma fase preparatória. Com a Woolf's Reform, foram previstas três situações distintas: small claim track, para ações com pequeno valor econômico; fast track, para ações com valor intermediário; multi track, para ações de maior complexidade.

O interim payment é uma ordem de pagamento expedida com base em um dano, um débito ou outra soma de dinheiro. A application deve vir acompanhada de uma prova evidente que comprove o direito do autor. O cartório notifica o réu que deverá tomar ciência do processo no prazo de catorze dias; depois, é fixada data para realização de audiência. Para a concessão da tutela, o juiz deve se convencer de que o direito é verossímil e se sustentará no processo de mérito. Em caso de condenação genérica por não apresentação de contestação ou impugnação, é obtido através do reconhecimento do próprio direito e, consequentemente, a condenação de pagamento da soma requerida na inicial. A decisão do interim payment não adquire força de coisa julgada, já que são decisões temporárias que podem ser questionadas. ${ }^{237}$

Em todos os sistemas processuais a característica marcante é a extensão da cognição. Em nenhum dos procedimentos é realizada uma cognição plena ou há qualquer discussão sobre o direito. Ao contrário, há somente discussão sobre os fatos e a análise de se a prova juntada aos autos corresponde aos requisitos exigidos em lei para o deferimento da tutela. ${ }^{238}$ Feita essa análise de ordenamentos de outros países, é

razones, de suerte que si el deudor no comparece o no se opone, está suficientemente justificado despachar ejecución, como se dispone. En cambio, si se dan razones, es decir, si el deudor se opone, su discrepancia con el acreedor se sustancia por los cauces procesales del juicio que corresponda según la cuantía de la deuda reclamada. Este juicio es entendido como proceso ordinario y plenario y encaminado, por tanto, a finalizar, en principio, mediante sentencia con fuerza de cosa juzgada. Si el deudor no comparece o no se opone, se despacha ejecución según lo dispuesto para las sentencias judiciales. En el seo de esta ejecución forzosa cabe la limitada oposición prevista en su lugar, per con la particularidad que se cierra el paso a un proceso ordinario en que se reclame la misma duda o la devolución de loque pudiera obtenerse en la ejecución derivada dal monitorio. Este cierre de las posibilidades de litigar es conforme y coherente con la doble oportunidad de defensa que al deudor le asiste y resulta necesario para dotar de eficacia el procedimiento monitorio".

237. Cf. Francesco Fradeani, I pressuposti e gli effetti delle misure cauteari in Europa: l'esperienza francese ed inglese, in: Antonio Carratta (org.), op. cit.

238. José Rogério Cruz e Tucci, op. cit., p. 44. 
interessante notar que todos buscam formar um título executivo de forma célere, ${ }^{239}$ mas não necessarimente iniciar uma execução (provisória ou definitiva) do título, sempre dando oportunidade de defesa ao réu. Caso esta não seja realizada ou seja insuficiente, comprovando o direito evidente do autor, é iniciada a execução. O estudo da tutela monitória é imprescindível para se compreender plenamente o sistema das tutelas diferenciadas, quais sejam, de cognição sumária: trata-se de um procedimento já consagrado e bem-sucedido em diversos países.

No Brasil, dizem que a monitória "não colou" porque todos os réus apresentavam embargos, o que a tornou totalmente sem sentido, pois o processo converte-se em uma discussão de processo ordinário. ${ }^{240}$ Há um péssimo costume, porém, de se afirmar com base na realidade pessoal, que muitas vezes não correspondente à realidade. E pior, muitas vezes mudanças legislativas são feitas sem se fazer qualquer pesquisa empírica sobre a questão. É o que ocorre no caso da monitória, pois, embora reze a lenda que ela não funcionou em razão do caráter litigante do brasileiro, não há qualquer estudo empírico sobre o assunto. ${ }^{241}$

Com base nessas impressões, a ação monitória foi excluída do projeto do CPC, o que só trouxe retrocessos, pois é um instituto já arraigado na nossa cultura, cujo cabimento os tribunais estabeleceram corretamente.

Por fim, o argumento mais importante para a manutenção da monitória no nosso sistema processual é que nesse mesmo projeto também é previsto a possibilidade de estabilização da tutela de urgência e evidência. Obviamente, essas tutelas não se confundem com a monitória, mas a técnica utilizada e o raciocínio são os mesmos: obter uma decisão efetiva sem a necessidade de se utilizar do processo ordinário e sem a necessidade de julgamento do mérito. Assim, acolher a estabilização da tutela de urgência e de evidência e excluir do projeto a ação monitória parece-nos um contrassenso, promovido apenas para atender aos insatisfeitos com o instituto.

239. E até mesmo por isso o procedimento monitório é tido como um processo de conhecimento.

240. Em pesquisa realizada pela professora Ada Pelegrini Grinover ficou demonstrado que "a forma mais difundida de tutela satisfativa antecipada encontrada nos países pesquisados consiste nos processos de estrutura monitória. Em linhas gerais, pode-se afirmar que o processo monitório responde à exigência de tutelar prontamente o direito do credor desprovido de título executivo, acelerando sua formação, sem necessidade de processo de conhecimento" (Ada Pellegrini Grinover, Tutela jurisdicional diferenciada: a antecipação e sua estabilização, in: O processo: estudos e pareceres, p. 86).

241. Tutela jurisdicional diferenciada no projeto de novo Código de Processo Civil, p. 188. 


\subsection{Consignação em pagamento}

Esse tipo de tutela tem seu procedimento previsto nos arts. 890 e seguintes do CPC. O $\S 1^{\circ}$ do art. 890 dá a possibilidade de o devedor realizar o pagamento em estabelecimento bancário, sendo sua obrigação avisar o credor. Caso o credor não manifeste a sua recusa o devedor estará livre da obrigação. Na hipótese de o devedor apresentar a sua recusa, obrigatoriamente por escrito, o devedor deverá propor a ação no prazo de trinta dias, juntando à inicial a prova do depósito realizado e a recusa do credor. ${ }^{242}$ É importante notar que o interesse à tutela jurisdicional somente surge após a recusa do credor em aceitar o valor do depósito. Caso não haja tal recusa, não há interesse processual para a propositura da ação. Na hipótese de negativa do credor em receber o valor depositado resta ao devedor apenas a tutela jurisdicional, que nada mais é que um "provimento jurisdicional declaratório da dissolução do liame obrigaciona por força do depósito; e, do ponto de vista do credor, a entrega, pelo primeiro, da quantia ou da coisa objeto da prestação". 243

Proposta a inicial, o juiz deverá deferir a liminar para que o depósito seja efetuado no prazo de cinco dias. A cognição nesse tipo de ação é sumária, limitada quanto à profundidade e às matérias que podem ser arguidas pelas partes. Na contestação, o réu somente pode alegar matérias específicas: 1) de que não houve a recusa em receber o depósito da coisa ou do valor; 2) de que, havendo recusa, ela foi justa; 3) de que o depósito não foi realizado no local ou prazo corretos; 4) de que o depósito não foi integral.

Por se tratar de uma ação específica, é necessário que o pedido do autor se adeque às regras procedimentais e limitações impostas, qualquer discussão que extrapole os limites impostos deverá ser através do procedimento ordinário. Ainda há uma discussão na doutrina sobre a necessidade de a obrigação ser líquida e certa. Conforme Marcato, essa exigência não está na lei, então não é possível imputá-la às partes.

\footnotetext{
242. “\$ $1^{\circ}$ Tratando-se de obrigação em dinheiro, poderá o devedor ou terceiro optar pelo depósito da quantia devida, em estabelecimento bancário, oficial onde houver, situado no lugar do pagamento, em conta com correção monetária, cientificando-se o credor por carta com aviso de recepção, assinado o prazo de 10 (dez) dias para a manifestação de recusa. $\S 2^{\circ}$ Decorrido o prazo referido no parágrafo anterior, sem a manifestação de recusa, reputar-se-á o devedor liberado da obrigação, ficando à disposição do credor a quantia depositada. $\S 3^{\circ}$ Ocorrendo a recusa, manifestada por escrito ao estabelecimento bancário, o devedor ou terceiro poderá propor, dentro de 30 (trinta) dias, a ação de consignação, instruindo a inicial com a prova do depósito e da recusa".

243. Antonio Carlos Marcato, Ação de consignação em pagamento, p. 51.
} 
Apesar da limitação de matérias que podem ser discutidas e que estão autorizadas no art. 896 do diploma processual, é possível discutir questões relacionadas à obrigação, tais como a natureza, valor ou origem do débito. ${ }^{244} \mathrm{O}$ autor cita Cândido Rangel Dinamarco em voto proferido no antigo $1^{\circ}$ Tribunal de Alçada Cível do Estado de São Paulo:

\begin{abstract}
Se é indispensável a oferta de coisa certa ou quantia determinada em unidades pecuniárias com precisão, isso não quer dizer que a dívida a extinguir precise transparecer, desde logo, numa límpida, cristalina e indiscutível liquidez. Nem que a impugnação do quantum ofertado feche as vias da consignatória para o prosseguimento até o julgamento do mérito. Isso estaria em conflito com a faculdade, que a lei dá ao credor, de contestar (como no caso concreto foi feito) a suficiência da oblação (art. 896, IV); e com aquela, do devedor, de complementar a oferta (art. 899). Como se compreenderia permitir ao réu uma defesa cuja simples dedução em juízo fosse desde logo e por si só impeditiva do julgamento do mérito, sendo impossível o exame de seus fundamentos e dos que lhe oponha o autor? Absurdo! [...] Tais preconceitos não teriam tido maior êxito e tanto trânsito entre conceituados doutrinadores e na jurisprudência tradicional, se se tivesse, há mais tempo, visão da natureza meramente declaratória da ação de consignação em pagamento e da função que desempenha a oblação liminar ao seu procedimento especial [...]. O depósito, sim, tem função constitutiva (negativa), pois elisivo da obrigação (CC, art. 972)..$^{245}$
\end{abstract}

Caso o réu reconheça a procedência do pedido, é proferida a sentença de mérito e ele é condenado ao pagamento de custas e honorários advocatícios. Caso o réu seja revel, a obrigação é declarada extinta e o réu também é condenado nas verbas sucumbenciais. ${ }^{246}$

\title{
2.3.2.2.3. Ações possessórias
}

As ações possessórias também se enquadram no conceito de tutela diferenciada, uma vez que as decisões proferidas nesse processo também possuem a cognição limitada. Nelas, a limitação ocorre na restrição da matéria que será levada a juízo (corte na cognição) tanto quanto na profundidade das matérias levadas a juízo e a sua investigação.

\footnotetext{
244. Idem, ibidem, p. 61.

245. Apud Antonio Carlos Marcato, op. cit., p. 63-64.

246. “Art. 897. Não oferecida a contestação, e ocorrentes os efeitos da revelia, o juiz julgará procedente o pedido, declarará extinta a obrigação e condenará o réu nas custas e honorários advocatícios. Parágrafo único. Proceder-se-á do mesmo modo se o credor receber e der quitação".
} 
As ações possessórias e sua proteção jurídica surgiram no direito romano, através dos interditos possessórios, como um meio de pacificação de disputas que existiam entre os cidadãos sobre invasão de terrenos, propriedades etc. Era um processo especial em que o pretor determinava, por meio do seu imperium, a cessação da violência e a reintegração ao proprietário. Era um processo relativamente simples se comparado ao processo formular e dividiam-se entre os intertidos contra a turbação da posse e o interdito para recuperação da posse. ${ }^{247}$

Existem diversos tipos de ações possessórias previstas no Código de Processo Civil brasileiro e muitos outras espécies não previstas na lei que decorrem da jurisprudência e de nossa tradição romano-germânica. ${ }^{248}$ Não trataremos especificamente de cada uma delas, mas abordaremos a natureza da tutela proferida em uma ação possessória investigando-a sob a perspectiva da sumariedade na cognição, além dos requisitos básicos para o deferimento de uma tutela possessória e o julgamento final desse tipo de ação.

É importante ter em mente que o objeto das ações possessórias é única e exclusivamente tutelar a posse, que é um estado de fato e não direito. Tanto que nas ações possessórias a cognição da matéria fica restrita a essa condição, não se

247. Em seu curso elementar de Direito Romano aponta as origens dos interdictum e os divide da seguinte forma: "Interdictum uti possidetis: Aplica-se em casos de turbação duradoura da posse de um imóvel. [...] Interdictum utrubi: Meio processual de proteção da posse de um móvel contra turbação. Em contraposição ao interdictum uti possidetis, protegia não o possuidor atual, mas o que possuíra durante mais tempo no período de um ano imediatamente anterior. Assim, podia servir também para recuperar a posse, conforme o caso. [...] Interdictum unde vi: Protegia a posse não viciosa de um imóvel contra o esbulho violentado. Só podia ser intentado dentro de um ano a contar do esbulho. [...] Interdictum de vi armata: Proteção em defesa de qualquer tipo de posse, inclusive a viciosa, contra esbulho violento a mão armada. [...] Interdictum de precario: Visava recueprar a posse de quem a recebera a título temporário, por liberalidade, para ser restituída a pedido do proprietário" (Thomas Marky, Curso elementar de Direito Romano, p. 91-92).

248. As ações possessórias têm origem no Direito Romano, em que eram previstas as ações específicas para recuperar a posse que havia sido perdida. Também podemos falar das ações petitórias, que não possuem previsão específica na lei processual, mas que são utilizadas pelo proprietário que perdeu um de seus direitos de propriedade. Não há previsão específica no CPC, tanto que elas são ajuizadas com nomen iuris de "ações ordinárias", e há a possibilidade de requerer a tutela antecipada prevista no art. 273 desde que preenchidas as suas hipóteses de cabimento. 
discutindo o direito de propriedade nesse caso. ${ }^{249}$ Assim dispõe o art. 924 do CPC, não permitindo a discussão sobre a propriedade. ${ }^{250}$

Outra característica importante das ações possessórias é a sua fungibilidade, ${ }^{251} \mathrm{ou}$ seja, o fato de ter sido ajuizado um tipo específico de ação possessória não impede que durante o processamento da ação essa se converta em outro tipo específico, já que o objeto da ação é a posse. Sendo a posse estado de fato, ela se altera muito durante o processamento da ação, daí se justificando sua fungibilidade.

Existem três tipos de ações possessórias: a reintegração de posse; a manutenção na posse; o interdito proibitório. ${ }^{252}$ Cada um se diferencia pelo grau de esbulho sofrido ou por sua ameaça. O caso da reintegração de posse se justifica caso o possuidor tenha perdido a posse, sofrido esbulho e queira recuperar a propriedade. Na ação de manutenção da posse, a parte não chegou a perder a posse, apenas foi molestada, justificando a propositura de ação judicial. Por fim, no interdito proibitório, o autor tem um justo receio de ser molestado na sua posse e pode requerer a tutela jurisdicional para evitar que esse dano ocorra.

Outra característica importante das ações possessórias é a limitação na cognição, aplicável também nas ações denominadas de posse velha, ou seja, proposta um ano e um dia após o esbulho. A respeito das ações de posse velha, não é pelo fato de a ação ter sido ajuizada após o prazo de um ano que ela perde a sua característica de ação possessória, tanto que o fundamento legal é o mesmo; a única diferença é que o pedido

249. "Nessa ação, a matéria a ser discutida deve ficar limitada ao conflito possessório, e assim as partes estão impedidas de alegar qualquer direito que puder ser invocado para a conservação ou a recuperação da coisa. Se a ação de reintegração é ação que, fundada na posse, objetiva a recuperação da coisa que se perdeu em virtude do esbulho - como está claro no art. 927 do CPC é evidente que o réu não pode se defender com base no domínio. O réu está proibido de apresentar defesa fundada em direito. Diante disso, como o juiz tem sua cognição limitada ao que pode ser discutido pelas partes, torna-se impossível a produção de prova relativa à necessidade de elucidação de questão que não esteja aí contida" (Luiz Guilherme Marinoni, Técnica processual e tutela dos direitos, p. 420). Essa é a teoria objetiva de Ihering, que sustentava que a forma mais correta de se provar a propriedade era através da posse. Uma vez que não existia um modo de se comprovar a propriedade - como hoje temos o registro em cartório - Ihering não admitia a alegação de propriedade como defesa. Esse pensamento persiste até hoje, apesar de nossa realidade histórica ser diferente da época em que foi concebida a teoria objetiva. Cf. Rudolf von Ihering, $O$ fundamento dos interdictos possessórios.

250. “Art. 924. Regem o procedimento de manutenção e de reintegração de posse as normas da seção seguinte, quando intentado dentro de ano e dia da turbação ou do esbulho; passado esse prazo, será ordinário, não perdendo, contudo, o caráter possessório".

251. “Art. 920. A propositura de uma ação possessória em vez de outra não obstará a que o juiz conheça do pedido e outorgue a proteção legal correspondente àquela, cujos requisitos estejam provados".

252. Não se desconhece a discussão doutrinária que enquadra as ações de nunciação de obra nova e de embargos de terceiro como ações possessórias. No entanto, em que pese esse entendimento doutrinário, consideramos melhor manter a separação que já existe no CPC. 
liminar baseia-se no art. 273 do CPC, sendo necessário provar todos os requisitos descritos naquele artigo.

Caso a ação seja proposta dentro do prazo de um ano e um dia o pedido liminar basear-se-á no art. 928 do CPC. ${ }^{253}$ Esse dispositivo legal não possui o requisito da urgência para a concessão imediata da tutela, que ocorre obrigatoriamente e sem a oitiva da parte contrária. Para o deferimento da liminar, basta que a inicial esteja instruída com os documentos necessários que a liminar deve ser deferida. Não fica a critério do juiz decidir se a liminar será ou não deferida - é uma imposição do legislador. ${ }^{254}$

Aqui cabe uma crítica a esse dispositivo. O art. 926 do CPC aduz que a medida liminar deva ser deferida, ou seja, é impositivo - o juiz deve fazer isso. Além disso, não há o requisito da urgência. Por outro lado, em casos de antecipação da tutela, mais especificamente das medidas autossatisfativas, a doutrina sempre se refere à necessidade de se avaliar o risco de irreversibilidade da decisão liminar concedida para evitar um dano maior ao réu. Há diversas críticas ao instituto na tutela de evidência, mesmo se tratando de hipótese em que há risco de vida (como caso de transfusão de sangue, cirurgia, medicamento). A escolha do legislador em tutelar a propriedade privada em detrimento da vida humana é evidente. Diante disso, conclui-se que a tutela possessória é a "tutela de evidência", conceito cunhado por Luiz Fux. Tanto a liminar em ação possessória como a tutela de evidência não incluem o requisito da urgência. Além disso, é necessário que os fatos já estejam previamente comprovados na ação possessória tal como na tutela de evidência. ${ }^{255}$

253. “Art. 928. Estando a petição inicial devidamente instruída, o juiz deferirá, sem ouvir o réu, a expedição do mandado liminar de manutenção ou de reintegração; no caso contrário, determinará que o autor justifique previamente o alegado, citando-se o réu para comparecer à audiência que for designada".

254. "Na hipótese da liminar do procedimento especial das ações possessórias, o legislador não se utilizou sequer de conceitos indeterminados; mesmo se estes fossem utilizados, não há que se cogitar de discricionariedade judicial. É dever, pois, do juiz conceder a medida liminar se concluir pela existência dos requisitos previstos em lei, bem como não conceder a providência liminar se concluir pela ausência dos requisitos legais" (Gleydson Kleber Lopes de Oliveira, Ações possessórias enfoque sobre a cognição, p. 62). No mesmo sentido, ver Antônio Carlos Marcato, Procedimentos especiais, p. 149.

255. "Nota-se, portanto, que a expressão 'tutela de evidência, inaugurada pelo processualista Luiz Fux para indicar a tutela provisória deferida com fundamento tão somente na evidência do direito reclamado pelo demandante, necessária para evitar que a demora natural do processo impeça a satissfação de um direito sobre o qual há grande probabilidade, aplica-se perfeitamente á liminar possessória. Isso porque, pelo que se denota das normas dos arts. 924 e 928 do Código de Processo Civil, a tutela jurisdicional pretendida por meio das ações possessórias, qual seja a proteção da posse contra esbulho, turbação e ameaça, será antecipadamente concedida, caso estejam 
Nas hipóteses de posse nova, ou seja, em que o esbulho ou ameaça são inferiores a um ano e um dia, o rito é o sumário, haja vista a necessidade de o autor se ver reintegrado na posse. Em contrapartida, no caso de posse velha, o procedimento é o ordinário, pois o autor não demonstrou interesse em proteger a sua posse no prazo adequado ele não tem tanta urgência em ver solucionada a questão. ${ }^{256}$

Outra característica importante das ações possessórias é que são ações dúplices, ou seja, em que o autor e o réu se confundem, podendo o réu deduzir um pedido na própria ação. E é exatamente isso que permite o art. 922 do CPC: “É lícito ao réu, na contestação, alegando que foi o ofendido em sua posse, demandar a proteção possessória e a indenização pelos prejuízos resultantes da turbação ou do esbulho cometido pelo autor".

O procedimento das ações possessórias é muito simples. Conforme o art. 928 do CPC, caso a inicial possua todos os elementos necessários, o juiz deverá deferir a liminar, sem ouvir o réu e sem a necessidade do requisito da urgência. Caso não estejam presentes os requisitos para o deferimento da liminar, o juiz determina a audiência de justificação prévia em que o autor expõe as suas razões para o deferimento da liminar e o réu é intimado para comparecer a essa audiência. Após a realização da audiência, inicia-se o prazo do réu para contestar a ação. Depois dessa fase inicial, o processo segue o rito ordinário, com a produção de provas, oitiva de testemunhas e perícia até a prolação da sentença. ${ }^{257}$

comrpvoados os requisitos exigidos pelo legislador. Logo, não há falar em natureza cautelar da liminar do procedimento especial dos interditos possessórios, porquanto é dotada de caráter satisfativo, e não somente preventivo, o que nos permite classificá-la como tutela antecipada satisfativa de evidência” (Fernando Jacob Netto, Tutela processual da posse, p. 163).

256. “A forma sumária é aqui imposta pela necessidade de pronto remédio ao possuidor, de celeridade e de prevenção de rixas a que dão lugar a delongas do processo, no que vai envolvido o alto interesse público. Quem deixou transcorrer o ano, mostra não ter necessidade de servir-se dos meios especiais estabelecidos por lei” (Tito Fulgêncio, Da posse e das ações possessórias, vol. I, p. 212).

257. “Art. 928. Estando a petição inicial devidamente instruída, o juiz deferirá, sem ouvir o réu, a expedição do mandado liminar de manutenção ou de reintegração; no caso contrário, determinará que o autor justifique previamente o alegado, citando-se o réu para comparecer à audiência que for designada. Parágrafo único. Contra as pessoas jurídicas de direito público não será deferida a manutenção ou a reintegração liminar sem prévia audiência dos respectivos representantes judiciais.

Art. 929. Julgada procedente a justificação, o juiz fará logo expedir mandado de manutenção ou de reintegração.

Parágrafo único. Quando for ordenada a justificação prévia (art. 928), o prazo para contestar contar-se-á da intimação do despacho que deferir ou não a medida liminar.

Art. 930. Concedido ou não o mandado liminar de manutenção ou de reintegração, o autor promoverá, nos 5 (cinco) dias subsequentes, a citação do réu para contestar a ação.

Art. 931. Aplica-se, quanto ao mais, o procedimento ordinário". 
A sentença desse tipo de ação é declaratória, pois reconhece o direito do autor em caso de procedência da ação, mas também possui uma carga executiva em si - a sentença é autoexecutável, e isso decorre da própria natureza da ação e da tutela da posse. 258

Nas ações possessórias também pode ocorrer o julgamento antecipado caso não seja dado o impulso processual necessário às ações, ou seja, a decisão liminar possessória produz efeitos como se fosse decisão de cognição profunda, porque a legislação específica assim permite. Na hipótese de ausência de impulso processual, a ação será julgada antecipadamente com os dados levados à inicial. ${ }^{259}$

258. "Seja de manutenção, seja de reintegração, o julgado impõe por si os seus efeitos, sem necessidade de um ulterior processo de execução: esta se restringe à expedição e cumprimento de um mandado, sem necessidade de outra citação ou formalidades outras. A 'autoexecutoriedade' da sentença deferitória da reintegração ou manutenção é característica da proteção interdital e, portanto, independente do rito, assim como independente de haver decorrido tempo maior ou menor $\mathrm{d}$ ano e meio desde a ofensa á posse até o ajuizamento da ação" (Adroaldo Furtado Fabrício, Comentários ao Código de Processo Civil, vol. VIII, p. 353).

259. "De outro lado, também nos procedimentos especiais impositivos da cognição sumária por vedação expressa à análise de determinadas matérias relacionadas ao objeto do litígio - ações possessórias, cambiárias, de desapropriação (Decreto-Lei 3.365 de 1941) e de busca e apreensão (Decreto-Lei 911 de 1969) - a ausência do impulso processual relacionado ao princípio da demanda por parte daquele que se sujeitou, ainda que de forma destoante da justiça do caso concreto, ao provimento sumário propicia a produção de eficácia e efeitos jurídicos por decisão não amparada em juízo cognitivo completo. $\mathrm{O}$ mesmo se dá nos procedimentos de da ação monitória e da execução de título judicial, nos quais, de alguma forma, a inércia do demandado é avaliado pelo ordenamento jurídico como reconhecimento da fragilidade de suas razões de defesa" (Alex Costa Pereira, Tutela sumária: a estabilização da tutela antecipada e sua adequação ao modelo constitucional do processo civil brasileiro, p. 115). 


\title{
2.3.2.2.4. Embargos de terceiro
}

Os embargos de terceiro são uma ação cujo objetivo é se ver livre de decisão judicial que atinja o patrimônio de terceiro, ou seja, que não faz parte do processo. Nesse caso, o ato que motivou a propositura da ação foi uma decisão judicial, a qual determinou um ato constritivo sobre o bem de propriedade de terceiro, agredindo sua posse, o que autoriza a propositura dos embargos de terceiro. Os arts. 1.046-1.054 do CPC regulamentam o procedimento, e fica claro que se trata de uma violência sobre a posse do bem de propriedade do terceiro:

\begin{abstract}
Quem, não sendo parte no processo, sofrer turbação ou esbulho na posse de seus bens por ato de apreensão judicial, em casso como o de penhora, depósito, arresto, sequestro, alienação judicial, arrecadação, arrolamento, inventário, partilha, poderá requerer lhe sejam manutenidos ou restituídos por meio de embargos.
\end{abstract}

Uma das grandes vantagens dos embargos de terceiro é a obtenção da liminar de ofício: basta a comprovação da posse ou propriedade para obrigar o juiz a conceder a liminar. ${ }^{260}$ Como nas ações possessórias, não é necessário comprovar a urgência da tutela, apenas comprovar de plano o seu direito (seja a posse ou a propriedade) ${ }^{261}$.

Note-se que a legitimidade para a propositura da ação de terceiro - que não participa do processo - pode incidir na fase de conhecimento ou na fase de execução. Geralmente, os atos executivos têm poder constritivo e autorizam a propositura de embargos de terceiro, mas, em processos de conhecimento, também podem ser proferidas decisões que acarretem interferência no patrimônio de terceiro. Principalmente se considerarmos a antecipação da tutela prevista no art. 273 e a antecipação prevista no art. $461, \S 3^{\circ}$ do CPC, é possível ser proferida uma decisão com conteúdo imediatamente executivo, permitindo a oposição de embargos de terceiro nessas hipóteses.

Há uma discussão doutrinária sobre os embargos de terceiro serem uma ação possessória, haja vista que há uma turbação ou esbulho, ainda que judicial, sobre bem de titularidade de terceiro. Com todo o respeito aos doutrinadores que assim sustentam,

260. “Art. 1.052. Quando os embargos versarem sobre todos os bens, determinará o juiz a suspensão do curso do processo principal; versando sobre alguns deles, prosseguirá o processo principal somente quanto aos bens não embargados".

261. É o que dispõe o $\S 1^{\circ}$ do art. 1.046 do Código de Processo Civil: "Os embargos podem ser de terceiro senhor e possuidor, ou apenas possuidor". 
não concordamos com tal posição. A turbação ou esbulho ataca a posse e também a propriedade, e ao contrário das ações possessórias, em que a limitação da cognição não permite a discussão sobre domínio, nos embargos de terceiro não existe tal proibição, podendo ser alegado o domínio ${ }^{262}$ e ser realizada ampla instrução probatória. O objeto das ações possessórias é somente a posse, estado de fato, ${ }^{263}$ e a propositura da ação é de direito material, enquanto o ato que dá ensejo aos embargos de terceiro é uma decisão judicial que extrapola seus efeitos para terceiro, não havendo limitação das matérias que podem ser alegadas.

Por fim, o inciso II do art. $1.047^{264}$ do CPC também autoriza a propositura de embargos de terceiro em casos de credor com garantia real. ${ }^{265}$

Não prosseguiremos na discussão da natureza dos embargos de terceiro, uma vez que nosso propósito é analisar os embargos de terceiro como uma tutela diferenciada. Como exposto, a liminar nos embargos de terceiro - sempre no sentido de obstar a prática dos atos constritivos e determinar a suspensão da decisão que ordenou a constrição - deve ser deferida de plano pelo julgador se todos os requisitos estiverem preenchidos. Como essa decisão é dada no início do processo, apenas com os elementos trazidos aos autos pelo autor, é evidente a sumariedade na cognição in casu, devendo ser considerada assim uma tutela diferenciada.

262. Nesse sentido Ricardo de Barros Leonel, Tutela jurisdicional diferenciada.

263. “A regra que dá identidade ao regime da proteção possessória no direito brasileiro é a da proteção da posse enquanto fato. Vale dizer, alguém que tenha consigo alguma coisa com ânimo de dono merece ser mantido na posse sem que, para tanto, se indague sobre a causa jurídica daquele estado de fato. É uma regra extremamente relativizada no próprio ordenamento, mas que ainda ostenta a condição de referência no estudo da proteção possessória” (Ruy Zoch Rodrigues, Embargos de terceiro).

264. “Art. 1.047. Admitem-se ainda embargos de terceiro: [...] II - para o credor com garantia real obstar alienação judicial do objeto da hipoteca, penhor ou anticrese".

265. Ainda há uma parte da doutrina que defende que os embargos de terceiro seriam cabíveis em qualquer hipótese de decisão judicial que determinasse a restrição, mesmo que o terceiro não tenha a posse sobre esse bem. Nesse sentido: Francisco Cavalcanti Pontes de Miranda, Comentários ao Código de Processo Civil, tomo XV; Humberto Theodoro Júnior, Curso de direito processual civil, vol. III; Donaldo Armelin, Dos embargos de terceiro, vol. 62. 


\subsection{Mandado de segurança}

O mandado de segurança é um remédio constitucional ${ }^{266}$ que pode ser impetrado contra o ato de autoridade pública que cometa abuso de poder ou alguma ilegalidade. ${ }^{267}$ Seu objeto é proteger o direito líquido e certo. Esses dois requisitos (direito líquido e direito certo) remontam à Constituição Federal de 1946 e são conceitos vagos, mas fica claro que o mandado de segurança tutela uma gama ampla de direitos que se podem ver violados por qualquer ato de autoridade pública. Por sua importância chegase a afirmar que o mandado de segurança seria um dos "mais importantes direitos do homem reconhecidos pelo Estado Democrático de Direito". ${ }^{268}$

$\mathrm{O}$ ato e a omissão da autoridade pública que autorizam a propositura do mandado de segurança poderá provir de qualquer um dos três Poderes, existindo exceções apenas: contra atos meramente normativos; contra decisões judiciais, inclusive a coisa julgada; em atos interna corporis de órgãos colegiados.

Sobre os atos meramente normativos, ou seja, lei em tese, não é possível obter mandado de segurança, pois eles não causam dano. É necessária a aplicação da lei, através de um ato de autoridade, para autorizar a propositura do mandamus. É

266. A origem constitucional do mandado de segurança está no artigo $5^{\circ}$, inciso LXIX, da Constituição Federal, que assim dispõe: "conceder-se-á mandado de segurança para proteger direito líquido e certo, não amaparado por 'habeas-corpus' ou 'habeas-data', quando o responsável pela ilegalidade ou abuso de poder for autoridade pública ou agente de pessoa jurídica no exercício de atribuições do Poder Público". Por ter origem direta em um artigo da Constituição, e não apenas no direito ao acesso ao Poder Judiciário como as demais ações, pode-se falar que os mandados de segurança são verdadeiros remédios constitucionais, uma vez que seu objetivo maior é proteger os princípios, garantias e direitos constitucionais. Nesse sentido: Darlan Barroso; Luciano Alves Rossato, Mandado de Segurança, p. 33).

267. Hely Lopes Meirelles, Arnoldo Wald e Gilmar Ferreira Mendes (Mandado de segurança e ações constitucionais, p. 34) discorrem sobre o conceito de ato praticado por uma autoridade pública: "Ato de autoridade é toda manifestação ou omissão do Poder Público ou de seus delegados, no desempenho de suas funções ou a pretexto de exercê-las. Por 'autoridade' entende-se a pessoa física investida de poder de decisão dentro da esfera de competência que lhe é atribuída pela norma legal. Deve-se distinguir autoridade pública do simples agente público. Aquela detém, na ordem hierárquica, poder de decisão e é competente para praticar atos administrativos decisórios, os quais, se ilegais ou abusivos, são suscetíveis de impugnação por mandado de segurança quando ferem direito líquido e certo; o agente público não pratica atos decisórios, mas simples atos executórios, e, por isso, não está sujeito ao mandado de segurança, pois é apenas executor de ordem superior. Exemplificando: o porteiro é um agente público mas não é a autoridade; autoridade é o seu superior hierárquico, que decide naquela repartição pública. $\mathrm{O}$ simples executor não é coator em sentido legal; coator é sempre aquele que decide, embora muitas vezes também execute sua própria decisão, que rende ensejo à segurança. Atos de autoridade, portanto, são os que trazem em si uma decisão, e não apenas execução".

268. Cf. Humberto Theodoro Júnior, O mandado de segurança segundo a lei 12.016, de 17 de agosto de 2009. 
importante diferenciar lei em tese de leis de efeito concreto, que são aquelas leis que já trazem em si a consequência prática pretendida sem nem mesmo ser aplicada. Isso ocorre muito na esfera municipal, no caso de plano diretor, em leis que restringem a circulação de veículos, como leis de rodízio. Apesar de ser uma lei, seus efeitos são imediatos e, por isso, podem ser atacadas por mandado de segurança. ${ }^{269}$

Há na doutrina toda uma discussão sobre a legitimidade passiva do mandado de segurança, analisando especificamente a autoridade coatora, em casos de empresas públicas e outros. Esse tema não está no escopo dessa dissertação, de modo que analisaremos a natureza do mandado de segurança, a natureza da decisão liminar, os requisitos para sua concessão, o limite da cognição realizada pelo juiz e a sentença.

Sobre a natureza do mandado de segurança, Humberto Theodoro Júnior assevera:

O mandado de segurança não é um simples processo de reconhecimento para declaração de direitos individuais. Nem se limita à condenação para preparar futura execução forçada contra o Poder Público. É procedimento especial com imediata e implícita força executiva contra os atos administrativos. Acolhida a segurança impetrada, o juiz vai além da simples declaração e condenação. Expede ordem de autoridade para cumprimento imediato. Fala-se, por isso, em ordem mandamental. ${ }^{270}$

O objetivo principal do mandado de segurança é afastar um dano já praticado por uma autoridade pública ou a ameaça desse dano. Assim, se deferida, a liminar a decisão tem natureza de ordem a ser cumprida pela autoridade coatora. Pode ser uma ordem para suspender o ato ou para a autoridade coatora praticar um determinado ato, na hipótese de mandado de segurança por omissão. ${ }^{271}$

O requisito essencial para a propositura do mandado de segurança e a concessão da decisão liminar é a existência de direito líquido e certo. É o que dispõe o art. $1^{\circ}$ da Lei 12.016/2009. ${ }^{272}$ Esse conceito de direito líquido e certo nada mais é do que uma

269. "Não contêm mandamentos genéricos, nem apresentam qualquer regra abstrata de conduta; atuam concreta e imediatamente, como qualquer ato administrativo de efeitos específicos, individuais ou coletivos, razão pela qual se expõem ao ataque pelo mandado de segurança" (Hely Lopes Meirelles; Arnoldo Wald; Gilmar Ferreira Mendes, op. cit., p. 40).

270. Humberto Theodoro Júnior, op. cit., p. 3.

271. "Equiparam-se a atos de autoridade as omissões administrativas das quais possa resultar lesão a direito subjetivo da parte, ensejando a impetração de mandado de segurança para compelir a Administração a pronunciar-se sobre o requerido pelo impetrante, e durante a inércia da autoridade pública não corre o prazo de decadência para a impetração" (Hely Lopes Meirelles; Arnoldo Wald; Gilmar Ferreira Mendes, op. cit., p. 35).

272. “Art. $1^{\circ}$ Conceder-se-á mandado de segurança para proteger direito líquido e certo, não amparado por habeas corpus ou habeas data, sempre que, ilegalmente ou com abuso de poder, qualquer 
prova robusta que deve ser apresentada na inicial no momento da impetração do mandamus, ou seja, direito comprovado de plano. ${ }^{273}$ A complexidade da prova, da matéria a ser realizada pelo juiz, não importa. $\mathrm{O}$ que é realmente importante para o mandado de segurança e a concessão da liminar é que a prova já esteja pré-constituída, não sendo necessário produzir qualquer prova ao longo do processo.

Trata-se do o ápice da tutela diferenciada. A cognição é sumária e limitada pelas informações trazidas pelo autor e após pelas informações trazidas ao conhecimeto do juiz pelo réu. Qualquer processo que tenha a necessidade de produção de provas não deverá ser resolvido via mandado de segurança, mas por processo de cognição plena e exauriente.

A desnecessidade da produção probatória se explica de forma lógica: um dos requisitos para a concessão da liminar em mandado de segurança é que a prova esteja pré-constituída - o denominado direito líquido e certo. Se é necessária a produção probatória não se trata de hipótese de direito líquido e certo, mas de fatos que deverão ser comprovados através de um processo de cognição plena.

Muito se discute se em mandado de segurança somente poderiam ser arguidas matérias de baixa complexidade, em razão da inexistência de fase de produção de provas. No entanto, esse argumento não se sustenta, a exigência do mandado de segurança é que o direito seja líquido e certo, não que a matéria a ser discutida nos autos seja simples. Mesmo que a matéria seja complexa, se já estiver pré-constituída nas provas juntadas na inicial, não há qualquer óbice à propositura do mandado de segurança.

Nesse sentido, já decidiu o Tribunal de Justiça de São Paulo: "as questões de direito, por mais intricadas e difíceis, podem ser resolvidas em mandado de segurança". ${ }^{274}$ Também a súmula 625 do Supremo Tribunal Federal permite que questões de direito possam ser resolvidas através de mandado de segurança: "Controvérsia sobre matéria de direito não impede concessão de mandado de segurança”. Novamente, a complexidade da questão, tanto fática quanto de direito, não interessa se ela já estiver pré-constituída.

pessoa física ou jurídica sofrer violação ou houver justo receio de sofrê-la por parte de autoridade, seja de que categoria for e sejam quais forem as funções que exerça".

273. Cf. Hely Lopes Meirelles; Arnoldo Wald; Gilmar Ferreira Mendes, op. cit.

274. TJSP, RT 254/104. 
O procedimento do mandado de segurança é bastante simples. A parte autora impetra o mandamus já instruído com toda a prova pré-constituída, o juiz analisa o pedido liminar e pode deferir a liminar, oportunidade na qual a autoridade coatora é notificada para prestar informações. Apesar de a lei utilizar o termo "notificar", ela tem os mesmos efeitos de uma citação, a partir da qaul começa a correr o prazo de dez dias para que sejam prestadas as informações. Por se tratar de uma ação constitucional, não se aplicam os efeitos da revelia. O juiz deverá julgar a ação conforme a prova préconstituída juntada nos autos, o que não levará, necessariamente, ao reconhecimento do pedido do autor. ${ }^{275}$

Para a concessão da liminar são necessários alguns requisitos específicos, quais sejam: relevância da fundamentação do mandado de segurança; risco de perecimento do direito caso não seja deferida a tutela liminar. ${ }^{276}$ No mandado de segurança individual, a tutela é sempre deferida inaudita altera parte, ou seja, antes de ouvida a parte contrária. É o que determina o referido dispositivo legal. Por outro lado, isso não ocorre no mandado de segurança coletivo. A liminar em referido mandamus somente pode ser outorgada após a oitiva da parte contrária. ${ }^{277}$

Geralmente, o mandado de segurança busca suspender um ato que esteja causando dano à parte, mas também pode ser impetrado nas hipóteses de ameaça a direito líquido e certo. É o caso do mandado de segurança preventivo, ao qual não basta que exista um risco hipotético. Para a comprovação do direito líquido e certo, reiteramos, é necessário haver uma prova documental robusta, prova pré-constituída do direito. No mandado de segurança preventivo esse exigência também é feita, não bastando a "suposição de um direito ameaçado"278.

Há também a possibilidade de ser obtido um mandado de segurança em razão da omissão da autoridade coatora. Isso ocorre muito nas hipóteses de processo administrativo em que o órgão público não se manifestou no prazo legal, o que pode

\footnotetext{
275. Humberto Theodoro Júnior, op. cit., p. 22.

276. É nesse sentido a redação do inciso III, do artigo $7^{\circ}$ da Lei 12.016/2009: “Art. $7^{\circ}$ Ao despachar a inicial, o juiz ordenará: [...] III - que se suspenda o ato que deu motivo ao pedido, quando houver fundamento relevante e do ato impugnado puder resultar a ineficácia da medida, caso seja por fim deferida, sendo facultado exigir do impetrante caução, fiança ou depósito, com o objetivo de assegurar o ressarcimento à pessoa jurídica".

277. “Art. 22. No mandado de segurança coletivo, a sentença fará coisa julgada limitadamente aos membros do grupo ou categoria substituídos pelo impetrante: [...] $\S 2^{\circ}$ No mandado de segurança coletivo, a liminar só poderá ser concedida após a audiência do representante judicial da pessoa jurídica de direito público, que deverá se pronunciar no prazo de 72 (setenta e duas) horas".

278. Hely Lopes Meirelles; Arnoldo Wald; Gilmar Ferreira Mendes, op. cit., p.31.
} 
levar a um prejuízo a parte autora, justificando, assim, a impetração do mandado de segurança.

Existe uma discussão sobre o cabimento do mandado de segurança contra atos judiciais. A rigor, o art. $5^{\circ}$, incisos II e III, é claro ao afirmar que não é possível impetrar o mandamus contra decisões que caibam recursos recursos com efeito suspensivo ou contra decisão transitada em julgado, uma vez que existem remédios processuais adequados para essas duas hipóteses. Os efeitos da decisão liminar se prorrogam no tempo até a prolação da sentença, ou seja, após ouvida a autoridade coatora. Como se trata de um procedimento extremamente célere em que a cognição é limitada, logo após de apresentadas as informações da autoridade coatora já é proferida a sentença. A sentença tem natureza substitutiva da decisão liminar, ou seja, se ela confirma a liminar, ela substitui integralmente a decisão proferida. Caso contrário, a decisão liminar fica substituída pela sentença que denegou a segurança. Proferida a sentença, não há qualquer dúvida ou discussão de que pode transitar em julgado, mesmo em se tratando de um processo de tutela diferenciada e de cognição sumária.

Antes da introdução do mandado de segurança era comum tal remédio constitucional ser utilizado como recurso para obtenção de efeito suspensivo perante os tribunais. Após a introdução do agravo de instrumento e a possibilidade de concessão de efeito suspensivo, tal utilização do mandamus mostrou-se desnecessária.

Em compensação, ainda existem situações em que é cabível o mandado de segurança contra ato judicial. São situações não previstas no sistema processual, faltando um mecanismo adequado para evitar lesão ou ameaça de lesão ao recorrente. ${ }^{279}$ Por exemplo, contra uma decisão proferida em cautelar de protesto que deferiu o protesto de imóveis e o registrou nas matrículas, contra decisão proferida pelo Juízo do Juizado Especial Cível à qual não é possível recorrer.

279. Cf. Cassio Scarpinella Bueno, $O$ mandado de segurança contra ato judicial e o parágrafo único do art. 527 do Código de Processo Civil, in: Mirna Cianci et al. (orgs.), op. cit., p. 89. No mesmo sentido, Kazuo Watanabe afirma: "Sua inserção [do mandado de segurança], no contexto do sistema de instrumentos processuais preordenados à tutela de direitos, se dá com função complementar, isto é para cobrir as falhas existentes no sistema criado pelo legislador ordinário" (Kazuo Watanabe, Controle jurisdicional (princípio da inafastabilidade do controle jurisdicional no sistema jurídico brasileiro) e mandado de segurança contra atos judiciais, p. 105). 


\subsection{Conclusão}

Os conceitos de tutela têm em comum a busca para a solução da morosidade do processo ordinário de conhecimento. Tal é o desafio atual do Judiciário e daqueles que se propõem a estudar o processo. Todos os conceitos expostos são todos meios para realização das tutelas em tempo razoável sem, contudo, ferir nenhum princípio processual ou constitucional, seguindo, inclusive, a proposta da Emenda Constitucional n. 45, de 2004.

Outra característica comum a todos os tipos de tutela é a sumariedade na cognição.

Não se pretende, obviamente, descartar o procedimento ordinário reservado a ações e discussões complexas, mas buscar uma alternativa mais célere que atenda a outros interesses. Por esse motivo, eis a solução apontada para tutelas de cognição sumária. A tutela diferenciada proporciona a efetividade tão alentada no primeiro capítulo deste trabalho. Uma resposta rápida do Estado que respeita as garantias processuais constitucionais e oferece à parte uma solução à lentidão do Poder Judiciário - a possibilidade de dar uma resposta rápida às partes, aliás, vai ao encontro da ideia da efetividade, representando uma conquista para o Poder Judiciário, ar dar uma solução efetiva para as partes. ${ }^{280}$

Como vimos, a tutela diferenciada possui requisitos específicos que devem ser seguidos em cada um dos procedimentos. Por exemplo, nos procedimentos de tutela de urgência, há o requisito do periculum in mora para a concessão da liminar, impossível sem a demonstração efetiva de um dano real à parte que pleiteou a medida. E a urgência do direito do autor deve ser provada de forma a convencer o juiz a modificar toda uma estrutura processual para evitar um prejuízo muito maior que a parte venha a enfrentar. Algo semelhante não ocorre com a tutela não urgente, em especial no caso da tutela de evidência. A urgência não é necessária para a outorga da tutela jurisdicional, cujo único requisito é a evidência do direito da parte que o pleiteou e a ausência de contestação séria do réu.

280. Nesse sentido, Ferrucio Tommaseo (op. cit., p. 73-74) afirma que o provimento cautelar é um próprio direito do Estado, pois este outorgou a tutela jurisdicional: "Ancora, quando si dice che il diritto al provvedimento cautelare 'è un diritto dello Stato' si fa riferimento al potere del giudice di porre in essere quelle misure che consentono, con il fruttuoso esercizio dell'attività giurisdizionale, l'attuazione dell'ordinamento: tesi questa che ben si armonizza con la concezione obiettiva della natura della funzione giurisdizionale, intesa come attuazione del diritto obiettivo mediante la realizzazione forzata della norma". 
Há os demais procedimentos, como a monitória - muito utilizada nos sistemas estrangeiros e com alto grau de satisfação -, através da qual é possível conseguir um título executivo de forma célere e, assim, satisfazer rapidamente a pretensão do autor. Também as ações possessórias, que podem ser classificadas como tutela sumária não cautelar porque não há o requisito da urgência para o deferimento da liminar, bastando que o autor comprove que sofreu esbulho ou ameaça a sua posse. Na consignação em pagamento, a cognição também é sumária, e as partes e o juiz estão limitados nas questões delimitadas pelo dispositivo legal. Os embargos de terceiro também possuem cognição sumária e, como nas ações possessórias, o juiz deve conferir a liminar se houver comprovação de que a decisão judicial interferiu no patrimônio de terceiro. Por fim, o mandado de segurança, considerado a tutela diferenciada por excelência uma vez que o autor junta na inicial todas as provas preconcebidas de seu direito, não sendo permitido qualquer tipo de instrução probatória no procedimento.

O grande problema está nas tutelas de urgência (tutela antecipada e tutela cautelar), em função de sua provisoriedade e instrumentalidade, e na tutela sumária não cautelar (tutela de evidência), a qual não exige sequer o requisito da urgência para a concessão da liminar, bastando a demonstração do direito evidente. Isso poderia ser considerado um atentado aos princípios e garantias constitucionais e processuais, mas, como demonstramos no quarto capítulo deste trabalho, a adoção dessas medidas em nada prejudicará as garantias outorgadas ao réu e ao autor. 


\section{TUTELA JURISDICIONAL DIFERENCIADA}

\subsection{Conceito}

Para definir o conceito de tutela diferenciada, cumpre primeiramente definir o termo “diferenciado", que designa tudo aquilo que não é normal, que é diferente, que não é ordinário. ${ }^{1}$

Em seguida, há o conceito de tutela ordinária. O procedimento ordinário de conhecimento possui fases demarcadas, cognição profunda e se desenvolve com amplo contraditório das partes. O procedimento ordinário, sem dúvida, é o mais exauriente e que garante maior segurança às partes. ${ }^{2}$ A satisfação da sentença somente ocorrerá quando ocorrer a plena certeza do direito.

O procedimento ordinário foi concebido pelo pensamento de função jurisdicional como efetivação da vontade concreta da lei e que somente a partir da sentença que haverá a satisfação da parte que venceu. Assim, sendo o processo de cognição exauriente um procedimento ordinário, até mesmo pela lógica, a tutela diferenciada é aquela alcançada em procedimento diverso do de cognição exauriente. ${ }^{3}$

Nesse sentido, podemos entender a tutela diferenciada como aquela em que a cognição não é aprofundada, e a realização das provas e participação das partes não são plenas. ${ }^{4}$ A tutela diferenciada é uma possibilidade que nos foi dada pelo legislador

1. Conforme Proto Pisani: "L'espressione tutela giurisdizionale differenziata è espressione altamente equivoca. Intessa letteralmente essa significa che a bisogni di tutela devono corrispondere forme diverse di tutela: di questa ovvietà nessuno ha mais dubbiato; tutto il sistema (o i sistemi) della nostra materia sono stati construiti sulla base di questa premessa: e così si è distinta la cognizione dalla esecuzione e nell'ambito della cognizione si sono distinte le azione (e le sentenze) di condanna dalle azioni (e dalle sentenze) di mero accertamento e costitutive, come nell'ambito della esecuzione si è distinto tra esecuzione forzata e esecuzione processuale indiretta e ancora nell'ambito della esecuzione forzata si è distinta l'espropriazione forzata (a sua volta suddivisa a seconda della specie del bene da espropriare) dall'esecuzione forzata per consegna o rilascio e per obblighi di fare o disfare" (Andrea Proto Pisani, Sulla tutela giurisdizionale differenziata, Rivista di Diritto Processuale, ano XXXIV, n. 4).

2. Cf. Kazuo Watanabe, Da cognição no processo civil.

3. Cf. Cristiano Rodrigo Del Debbio, Tutela jurisdicional diferenciada: técnicas para sumarização da cognição.

4. "Tutela jurisdicional diferenciada quer significar, em um certo sentido, nas palavras de Luiz Guilherme Marinoni, tutela adequada à realidade do direito material. Se uma determinada pretensão de direito material está envolvida numa situação emergencial, a única forma de tutela adequada dessa pretensão é aquela que pode satisfazer com base em cognição sumária”. Carlos 
ao permitir diversos procedimentos que possam tutelar situações subjetivas diferentes entre si.

Para Donaldo Armelin, a tutela diferenciada pode ser analisada por dois ângulos: pelo conteúdo - ou seja, o atendimento da pretensão da parte - quanto pelo procedimento - fugindo muitas vezes das regras procedimentais ordinárias. ${ }^{5}$

Segundo Proto Pisani, ${ }^{6}$ há algumas exigências para o surgimento da tutela de cognição sumária, e para esta prevalecer em relação a de cognição plena:

- economia processual: o processo de cognição plena não é necessário em todas as situações, devendo ser restringido apenas às hipóteses que assim exigirem, consequentemente, isso acarreta em uma economia no custo do processo;

- evitar o abuso do direito de defesa do réu: há situações de direito evidente (conforme tratado no capítulo XX) - isso porque há situações em que o réu somente utiliza do ônus da contestação com finalidades meramente protelatórias;

- exigência de efetividade da tutela requerida - a efetividade aqui está diretamente relacionada à fase executiva, à "fruttuosità pratica della futura sentenza coletiva"7.

Temos, portanto, a primeira grande característica da tutela diferenciada: a sumarização da cognição. E essa característica atende outra necessidade do Judiciário, que é a entrega da tutela jurisdicional de maneira célere, sem prejudicar o contraditório e, consequentemente, produzindo os mesmos resultados que o processo ordinário. ${ }^{8}$ Nesse sentido, não há dúvida de que a grande vantagem da tutela diferenciada é exatamente a celeridade no provimento, ou, como diria Dinamarco, a "oferta de resultados", porque "os resultados oferecidos são substancialmente os mesmos que se poderiam obter por outras vias". 9 Assim, em algumas situações a tutela diferenciada

Alberto Garbi, Tutela jurisdicional diferenciada e efetividade do processo, Revista dos Tribunais. ano 89. Vol. 782. Dezembro 2000, p. 60.

5. "Um, adotando como referencial da tutela jurisdicional diferenciada a própria tutela, em si mesma, ou seja, o provimento jurisdicional que atende a pretensão da parte, segundo o tipo da necessidade de tutela ali veiculado. Outro, qualificando a tutela jurisdicional diferenciada pelo prisma de sua cronologia no iter procedimental em que se insere, bem assim como a antecipação de seus efeitos, de sorte a escapar das técnicas tradicionalmente adotadas nesse particular" (Donaldo Armelin, Tutela jurisdicional diferenciada, Revista de Processo, vol. 65, p. 46).

6. Andrea Proto Pisani, La tutela sommaria in generale e il procedimento per ingiunzione nell'ordinamento italiano, Revista de Processo, vol. 23, n. 90, p. 22-35.

7. Idem, ibidem.

8. Cf. Cristiano Rodrigo Del Debbio, op. cit.

9. Cândido Rangel Dinamarco, Instituições de direito processual civil, vol. 3, p. 736. 
caracteriza-se tanto pela urgência da tutela requeridas ao juízo quanto pela evidência de seu direito. ${ }^{10}$

A limitação da cognição é o ponto central da tutela diferenciada, adotando-se aqui o conceito de limitação tanto no plano vertical quanto horizontal.

Há, ainda, outra característica marcante da tutela diferenciada: a tipicidade. Isso significa que, em muitas situações, a tutela diferenciada provém de um procedimento específico típico e, por isso mesmo, não ordinário. São oportunizadas aos jurisdicionados novas formas de tutela, através de processos diferenciados, com ritos específicos, para que os jurisdicionados alcancem a tutela de forma célere. ${ }^{11}$

Donaldo Armelin, logo no início de seu clássico estudo da tutela diferenciada, assevera que como o objetivo da tutela diferenciada é diferente da tutela ordinária, é necessário um instrumento adequado e típico que se preste a essa finalidade. ${ }^{12}$ Nesse ponto, não há novidade do termo "tutela jurisdicional diferenciada", ${ }^{13}$ pois a tutela diferenciada está baseada na premissa de que para tutelar situações diversas é necessário uma forma de prestação diferenciada. A tipicidade, demonstramos a seguir, é deveras importante para a tutela diferenciada, uma vez que, para assegurar a tutela, todos os princípios processuais foram seguidos, sem ferir nenhum dos direitos das partes.

Somam-se então mais duas características principais da tutela diferenciada: celeridade e tipicidade.

Ricardo de Barros Leonel define tutela jurisdicional diferenciada como uma “proteção jurídica e prática outorgada pelo Estado-juiz, resultante da utilização de

10. Como demonstrado, a tutela diferenciada não ocorrerá necessariamente em situações urgentes, mas, sim, pela peculiaridade dos fatos colocados em juízo, se evidente. Todos os demais procedimentos não urgentes acima descritos tinham a evidência como característica principal, seja por escolha do legislador seja pela realidade posta dos fatos. Nesse sentido, cf. Adroaldo Furtado Fabrício, Breves notas sobre provimentos antecipatórios, cautelares e liminares, Revista da Ajuris, vol. 66, p. 8 .

11. Cf. Rogério Aguiar Munhoz Soares, Tutela jurisdicional diferenciada.

12. Cf. Donaldo Armelin, Tutela jurisdicional diferenciada, Revista de Processo, n. 65, p. 45: "Realmente, presentes diferenciados objetivos aserem alcançadospor uma prestação jurisdicional efetiva, não há porque se manter um tipo unitário destaou dos instrumentos indispensáveis a sua corporificação. A vinculação do tipo da prestação à sua finalidade específica espelha a atendibiidade desta; a adequação do instrumento ao seu escopo potencia o seu tônus de efetividade".

13. Cf. Rogério Aguiar Munhoz Soares, op. cit., p. 135: "Na verdade, a tutela jurisdicional diferenciase na medida que o ordenamento proporciona formas de proteção diferenciadas em relação à já previstas, proporcionando alternativas ao demandante em face do processo de cognição exauriente, ou inserindo nos diversos modelos processuais medidas que os capcitem a propiciar tutela jurisdicional adequada". 
procedimentos especiais previstos no ordenamento processual, em que a celeridade e efetividade da prestação jurisdicional decorra da limitação da cognição". ${ }^{14}$ Algumas características do conceito ficam evidentes:

- tipicidade do procedimento - não é uma característica essencial, mas, em um processo cujo resultado será diferenciado, o procedimento para sua outorga também será diferenciado;

- limitação da cognição - com certeza, o aspecto mais importante da tutela diferenciada, pois, não importando o tipo de procedimento (cautelar ou não), a cognição será sumária;

- celeridade - uma das finalidades da tutela diferenciada.

No mesmo sentido, Donaldo Armelin aponta duas características fundamentais. A primeira é o resultado diferenciado que a tutela proporcionará, enquanto a segunda é o fato de essa tutela se originar de um procedimento não ordinário. O resultado diferenciado, como explica o autor, está mais relacionado aos resultados da tutela, à “perenidade destes no tempo, afetando a temporalidade da atuação jurisdicional ou a permanência e atuação destes no espaço jurídico, com a sua imunização frente a prestações idênticas, geradas em instrumento processual decorrente de ação também idêntica". ${ }^{15}$ Ou seja, a provisoriedade e a não duração no espaço temporal da tutela diferenciada. Já a segunda característica apontada pelo autor está ligada à tipicidade do procedimento. Seria uma tutela prestada em um processo diferenciado, marcado pela cognição sumária com a sua consequente simplificação.

Por fim, não se deve falar de tutela diferenciada sem recordar da busca do resultado prático do processo. Isso porque, reiteramos, a tutela jurisdicional não consiste apenas na busca por uma sentença de mérito, que muitas vezes de nada resolve, mas sim na própria satisfação do direito.

$\mathrm{Na}$ Itália, a tutela diferenciada também existe e foi cunhada a partir do conceito proposto por Proto Pisani. Inclusive, há na Constituição italiana uma previsão muito parecida com a que há na brasileira, a fim de garantir pleno acesso ao Poder Judiciário, ${ }^{16}$ mas, como naquele país, não basta proporcionar acesso ao Poder

\footnotetext{
14. Ricardo de Barros Leonel, Tutela jurisdicional diferenciada, p. 79.

15. Donaldo Armelin, Tutela jurisdicional diferenciada, Revista de Processo, p. 46.

16. “Art. 24 - Tutti possono agire in giudizio per la tutela dei propri diritti e interessi legittimi. La difesa è diritto inviolabile in ogni stato e grado del procedimento. Sono assicurati ai non abbienti,
} 
Judiciário se não for outorgada a tutela jurisdicional. Assim, na Constituição italiana aplica-se a máxima chiovendiana de que o processo deve proporcionar exatamente aquilo a que a parte tem direito. ${ }^{17}$

Dessa forma, no ordenamento jurídico italiano são previstos dois tipos essenciais de tutela diferenciada: o primeiro, tutela jurisdicional diferenciada baseada na urgência, mais simplificado que o procedimento ordinário; o segundo é o procedimento sumário não cautelar. ${ }^{18}$

De todo o exposto, pode-se concluir que a tutela diferenciada é aquela proferida em procedimento específico, de cognição sumária, sempre na busca pela efetividade da tutela jurisdicional.

\subsection{Características}

\subsubsection{Tipicidade}

Primeiramente, o procedimento nada mais é uma sequência de atos que são previstos em lei. ${ }^{19}$ Essa previsão legal assegura às partes, antes de iniciarem o litígio, saber as regras do jogo e haver uma previsibilidade das decisões judiciais, não surpreendendo as partes e afastando o que atualmente costuma se chamar de justiça lotérica.

Esses atos conectados uns aos outros não fazem sentido se não forem praticados na sequência predeterminada em lei - sua sucessão conforme a ordem prevista em lei é a característica marcante do procedimento. Tanto que, caso um dos atos processuais seja anulado, todos os atos subsequentes, que dependam do ato anulado, também serão prejudicados. $^{20}$

con appositi istituti, i mezzi per agire e difendersi davanti ad ogni giurisdizione. La legge determina le condizioni e i modi per la riparazione degli errori giudiziari" (Costituzione della Repubblica Italiana, 1946).

17. "Il processo deve dare per quanto possibile praticamente a chi ha un diritto tutto quello e proprio quello che eglio ha diritto di conseguire" (Giuseppe Chiovenda, Istituzioni di diritto processuale, vol. 1.).

18. Liugi Montesano, Luci ed ombre in leggi e proposte di tutele differenziate nei processi civile, Rivista di Diritto Processuale, ano XXXIV, n. 4, p. 593.

19. Elio Fazzalari, Istituzioni di Diritto Proessuale, p. 75.

20. Nesse sentido é o art. 248 do CPC: “Anulado o ato, reputam-se de nenhum efeito todos os subsequentes, que dele dependam; todavia, a nulidade de uma parte do ato não prejudicará as outras, que dela sejam independentes". Roque Komatsu também escreve sobre o tema: "Além da coordenação, o procedimento se caracteriza pela ordem na sucessão, não só de atos processuais, mas também de fatos jurídicos, bem como e operações materiais ou de atos materiais. E como eles 
A forma e o procedimento como deve ser realizada a atividade jurisdicional é uma exigência constitucional: assegura às partes a previsão de como se desenvolverá o processo, garantindo a ampla defesa, o devido processo legal e o contraditório. ${ }^{21,22}$

Como bem assevera Calmon de Passos, o processo já é uma tipificação em si, ao proibir a autotutela e determinar que o litígio deve ser resolvido através do Estado. Ao contrário do direito material, em que o Direito surge apenas após as situações da vida, para tutelar a situação, o direito processual tem formas predefinidas pelas quais o autor deve ter seu interesse tutelado, utilizando procedimentos específicos mais adequados ao caso concreto. Isso porque o Estado-juiz não pode simplesmente não entregar a tutela jurisdicional sob o argumento de que não há previsão legal: o acesso ao Poder Judiciário é garantido a todos e cabe ao Estado proporcionar meios e procedimentos específicos que tutelem esses direitos. ${ }^{23}$

constituem as chamadas formalidades, tem-se que o procedimento é sucessão legalmente ordenada de formalidades. No procedimento, as formalidades que o integram obedecem a uma determinada ordem de sucessão, fixada de harmonia com a natureza do fim que especificamente se persegue. O número e a ordem da sucessão das formalidades constitutivas estão predeterminadas na lei; os seus elementos estão minuciosamente regulados. A preterição das formalidades legalmente determinadas pode inquinar o ato processual por vício de forma. E este pode influir na legalidade formal do ato ou dar origem á responsabilidade disciplinar ou a qualquer outra forma de sanção" (Roque Komatsu, Da invalidade no processo civil, p. 114).

21. "Predetermina-se não somente a forma, o modo de que se deve revestir a atividade processual, mas também, e imperativamente, a espécie de atividade que cumpre seja desenvolvida para que se obtenha a prestação jurisdicional reclamada do Estado. Esta prefixação, em termos cogentes, da atividade a ser desenvolvida no processo pelos sujeitos que se tornem seus protagonistas é exigência constitucional, particular e peculiarmente relevante para o direito processual, além de necessária para compreensão de muitos de seus institutos" (José Joaquim Calmon de Passos, Esboço de uma teoria das nulidades aplicada às nulidades processuais, p. 77).

22. É semelhante o entendimento de Ovídio Araújo Baptista da Silva: "Cabe aos processualistas, sem dúvida, a tarefa de encontrar os limites adequados para esse novo princípio, agora estendido ao processo civil. Não se deve, no entanto, perder de vista o fato inegável de que a diversificação dos ritos procedimentais não só atende à maior aderência dos mecanismos processuais às 'características de cada direito material' posto em causa, como é justamente a diferenciação ritual 'un' esigenza insopprimibile per un ordinamento che si ispira al principio di eguaglianza' (N. Trocker, Processo civile e costituzione, p. 701). Isto significa duas coisas igualmetne importantes: a) na medida em que o processo oferece aos diferentes direitos materiais que lhe cabe tratar, procedimentos diferenciados e, tanto quanto possível, adaptados a suas exigências peculiares, fortalece-se o princípio da instrumentalidade do processo, tornando-o funcionalmetne adequado e harmônico com sua finalidade de dispositivo realizador do direito material; b) significa também o reconhecimento da velha verdade, tão conhecida dos filósosofos e dos juristas, de que a observância do princípio da igualdade - elemento essencial à ideia de direito - exige que se tratem desigualmente as coisas desiguais" (Ovídio Araújo Baptista da Silva, A plenitude de defesa no processo civil, in: Da sentença liminar à nulidade da sentença, p. 127).

23. A explicação de Calmon de Passos é magnífica e merece ser transcrita: "O direito apenas qualifica, na massa imensa dos atos humanos, determinados atos, aos quais associa consequências suscetíveis de serem implementadas juridicamente. Bem diverso é o que ocorre no campo do direito processual. Havendo interditado ao particular a tutela de seus direitos com auxílio de suas próprias forças (a defesa privada), o Estado (ou que outro nome tenha o centro de poder político) predetermina certa forma de atividade juridicamente relevante, mediante a qual os cidadãos devem 
Nesse contexto é importante o estudo da tipicidade processual.

O conceito de tipicidade é muito utilizado no direito penal, pois o crime é considerado praticado apenas se estiver tipificado no Código Penal ou em leis especiais: a conduta penal deve estar prevista na lei, não admitindo interpretações. $O$ rigorismo da tipicidade no direito penal se justifica na medida em que a conduta antijurídica pode levar à restrição da liberdade individual, o que é muito caro para o Estado Democrático de Direito.

Como ensina Miguel Reale Júnior, o conceito de tipo é o de uma ação típica que ocorreu no caso concreto, foi abstraída e formulada pelo legislador, ou seja, o modelo, o tipo penal foi construído a partir da realidade, já baseado em uma conduta antijurídica que ocorreu. ${ }^{24}$

Já no processo civil, o conceito de tipicidade não é muito explorado, haja vista que, como afirmamos, o nosso ordenamento é baseado na tutela do direito material e não em um sistema de ações, como era no antigo direito romano. Dessa forma, entende-se que qualquer lesão jurídica deve ser levada ao conhecimento do Judiciário independentemente de haver um instrumento processual adequado, e o nome da ação não importa para a outorga da tutela jurisdicional pelo Estado.

Em concordância com esse entendimento, nos filiamos à corrente da instrumentalidade processual, por considerar que o processo não pode servir de empecilho para as soluções jurisdicionais. No entanto, em algumas situações específicas é necessário que o procedimento escolhido para a outorga da tutela seja típico. ${ }^{25}$ Aqui podemos pensar tipicidade como procedimento correto, com fases

reclamar-lhe a proteção de que se fez monopolizador e também pela qual ele mesmo, Estado-juiz, se compromete a adimplir a prestação da tutela jurisdicional que lhe é reclamada. Não foram selecionados, dentre vários comportamentos ditados pelas necessidades da vida, aqueles merecedores de formalização jurídica. Criou-se uma forma de comportamento, predeterminou-se atividade que se teve como adequada para atender às necessidades do Estado-juiz no seu perfil político" (José Joaquim Calmon de Passos, op. cit., p. 75).

24. "Destarte, tipo penal como estrutura não é uma construção arbitrária, livre, mas decorre do real, submetido a uma valoração. A estrutura é própria do objeto e a revelação da sua estrutura indica a inteligibilidade do objeto, a sua composição interna, 'como um todo cujas partes são ligadas entre elas e cujos termos são definidos por suas relações, de tal forma que a modificação de um dos elementos ocasiona a dos outros'. Segundo Engish, a ação típica decorre de uma passagem do concreto ao concreto por meio do abstrato, ou seja, o legislador da realidade constrói o modelo, o qual se amolda ao comportamento futuro, pela presença no concreto dos dados elementares invariáveis que ele descreve. A construção normativa é, contudo, sempre orientada na direção do significado da ação, cuja positividade afirma-se ou nega-se" (Miguel Reale Júnior, Instituições de direito penal, vol. I, p. 135-136).

25. "Pela terminologia utilizada pelo Código de Processo Civil, tem-se num primeiro momento, a impressão de que o nosso Sistema Processual vem estruturado em ações típicas. Assim é porque, 
demarcadas, sem surpresas para as partes, e mais: um procedimento que não seja ordinário, mas específico para cada uma das tutelas pleiteadas. Por exemplo, as ações possessórias que em geral preveem um procedimento específico para cada questão levada ao Judiciário.

Essa ideia do ato processual como um ato jurídico para regular uma conduta, a exigência da criação de atos já prefixados em lei, fases, comportamento das partes, foi abordada por muitos estudiosos do processo, não necessariamente na área cível, concentrando-se sobretudo na área penal. Carnelutti, em sua obra de processo penal que melhor analisa essa questão, afirma que o processo é uma sequência de atos predeterminados para alcançar um uma finalidade, que é a entrega da tutela jurisdicional. Cumpre ao processo traçar esses atos predeterminados, esse caminho a ser percorrido pelas partes, e construir um modelo pelo qual as partes devem adaptar o seu comportamento. Esses modelos processuais denominam-se tipo (fattispecie). ${ }^{26}$

Como conceitua Calmon de Passos: "O tipo (fattispecie) do ato é, pois, o modelo, ou também se poderia dizer a amostra do ato que o legislador constrói com o objetivo de regular o procedimento, isto é, de fazê-lo idôneo para o fim. ${ }^{27}$ "

Essa sequência de atos traçada pelo legislador constitui a própria legalidade dos atos processuais: o modelo a ser seguido pelas partes deve ser conforme com a lei, respeitando os princípios e garantias processuais.

Nesse sentido, Barbosa Moreira foi afirma a necessidade da criação de um "programa básico da campanha em prol da efetividade", de modo que "o processo deve ter instrumentos de tutela adequados, na medida do possível, a todos os direitos (e

quer nesse Diploma Legal, quer em legislações especiais, utiliza-se a expressão ação vinculada ao próprio direito material, redundando em uma diversidade de ações, como, por exemplo, ação de consignação em pagamento, de prestação de contas, renovatória de locação, despejo por falta de pagamento, reivindicatória, de reintegração de posse e de usucapião. A adoção dessa concepção da expressão ação conduziria à equivocada conclusão de que, se no sisstema processual inexistisse uma ação típica para a defesa de determinado direito subjetivo, não teria seu titular instrumento processual apra defendê-lo, caso violado. Na realidade, nesses casos, a ação enquanto direito subjetivo público a obter um provimento jurisdicional de mérito, é única. Idênticas são as condições da ação para todas elas. Outrossim, o que se percebe é a necessidade, até em função da natureza do direito material a ser protegido, de serem estabelecidas técnicas procedimentais diferenciadas, dando ensejo, então aos procedimentos especiais que se contrapõem ao procedimento comum ordinário e sumário. Conclui Cândido Rangel Dinamarco, então, que 'no Direito moderno, como já ficou dito, inexiste lugar para ações civis típicas (salvo a rescisória, como se verá). Típicos são, com maior ou menor intensidade, os direitos alegados pelas partes e em torno de cuja existência ou inexistência o processo de conhecimento girará" (Rogério Marrone de Castro Sampaio, Embargos de terceiro, p. 18).

26. Francesco Carnelutti, Lecciones sobre el proceso penal.

27. José Joaquim Calmon de Passos, op. cit., p. 78. 
outras posições jurídicas de vantagem, que resultem de expressa previsão normativa, quer se possam inferir do sistema". ${ }^{28}$ Esse instrumento de tutela adequado nada mais que é uma ação específica para tutelar situações que requerem um tipo específico em razão do direito material veiculado.

A previsão específica de um procedimento não tem o intuito de complicar o processo, mas, pelo contrário, garantir que as partes tenham paridade de armas e segurança jurídica. E isso ainda é mais justificável em processo de tutela diferenciada, entendido como de cognição sumária, no qual é necessário garantir ao réu que ele terá seu direito de defesa garantido e ao autor que ele terá a sua tutela jurisdicional outorgada em tempo razoável. ${ }^{29}$

Reafirmamos que uma das principais características da tutela diferenciada é a tipicidade do procedimento. ${ }^{30}$ São processos cuja cognição é limitada e, por isso, possuem um procedimento especial para a concessão dessa tutela para não ferir os princípios processuais e, ao mesmo tempo, outorgar a tutela de modo célere. Trata-se de uma característica marcante, uma vez que apenas em procedimento não ordinário é proferido esse tipo de tutela, devido sobretudo à limitação na cognição.

Dessa forma, compartilhamos do entendimento de Ricardo de Barros Leonel de que o direito à tutela jurisdicional é atípico, uma vez que o legislador não pode prever todas as hipóteses. Por outro lado, devendo a tutela diferenciada ser outorgada somente

28. José Carlos Barbosa Moreira, Efetividade do processo e técnica processual, Revista de Processo, vol. 20. n. 77. O doutrinador ainda elenca uma série de mudanças necesssárias à busca da efetividade da tutela jurisdicional: "b) esses instrumentos devem ser praticamente utilizáveis, ao menos em princípio, sejam quais forem os supostos titulares dos direito (e das outras posições jurídcas de vantagem) de cuja preservação ou reintegração se cogita, inclusive quando indeterminado ou indeterminável o círculo dos eventuais sujeitos, c) impende assegurar condições propícias à exata e completa reconstituião dos fatos relevantes, a fim de que o convencimento do julgador corresponda, tanto quanto puder à realidade; d) em toda a extensão da possibilidade prática, o resultado do processo há de ser tal que assegure à parte vitoriosa o gozo pleno da específica utilidade a que faz jus segundo o ordenamento; e) cumpre que se possa atingir semelhante resultado com o mínimo dispêncio de tempo e energias" (idem, ibidem).

29. Entenda-se a tutela jurisdicional de forma ampla, como uma resposta do Estado, e não como uma obrigação em acolher o pedido do autor. Se assim fosse, estaríamos voltando ao tempo do processo do autor. Não é essa a intenção, mas apenas dar uma resposta (ainda que negativa) do pedido formulado pelo autor.

30. Tucci afirma expressamente que a tutela diferenciada é estruturada em vários procedimentos, e estes são organizados de acordo com as pecualiridades do caso concreto: "Tenha-se presente que a locução tutela jurisdicional diferenciada, cunhada inicialmente por Proto Pisani, é utilizada para indicar, em contraposição ao procedimento ordinário, a reunião de vários procedimentos estruturados a partir de peculiaridades de certas categorias de situações substanciais - de natureza plenária ou sumária (cautelar ou sumária tout court), e que se apresentam como uma das vertentes para sintonizar a justiça civil às garantias processuais ditadas pelo texto constitucional" (José Rogério Cruz e Tucci, Ação monitória: Lei 9.079 de 14.7.1995, p. 19). 
em procedimento típico, com regras específicas e bem delineadas, sob pena de ferir os princípios processuais, surge a necessidade de tipificação da tutela.

Parte-se da situação de direito material que exige uma resposta diferente do Estado, à qual aquela resposta do procedimento ordinário não é suficiente, pois não atende aos interesses das partes e, em última instância, não será efetiva. O legislador oportunizou, então, a possibilidade de se oferecer um remédio típico e diferente do procedimento ordinário em que é possível acautelar o interesse da parte. ${ }^{31}$ Isso porque o procedimento ordinário e sua demora não são compatíveis com os interesses buscados através da tutela diferenciada. Pois trata-se de situações geralmente urgentes, em que há a probabilidade de perecimento do direito, ou de situações de direito evidente.

A tipicidade decorre da necessidade de se acautelar uma situação atípica que demanda uma solução diferente, e, consequentemente, da necessária adaptação do rito processual.

Como no Brasil, a Itália possui alguns instrumentos processuais típicos que outorgam tutela diferenciada. No sistema italiano também há a especificidade do procedimento, e somente pode ser concedida a tutela se houverem alguns requisitos específicos. A tutela diferenciada italiana possui algumas características em comum com a brasileira, como o contraditório diferido e a limitação da cognição.

No sistema alemão, também há previsão de, ao menos, dois procedimentos típicos de cognição sumária, nos quais o julgador outorga uma tutela diferenciada, entre eles o procedimento documental e o monitório (o primeiro adotado no Brasil). Ao contrário do procedimento monitório brasileiro, o alemão é baseado apenas na verossimilhança das alegações do autor. Nos dois procedimentos, o julgador pode outorgar uma ordem para obtenção de um título executivo e, consequentemente, uma rápida satisfação do credor. No procedimento monitório, a limitação da cognição é evidente, uma vez que não é analisada outra prova documental a não ser a colhida pelas partes e o depoimento

31. Ferrucio Tommaseo, ao falar das diferentes formas de tutela diferenciada, afirma que o legislador deixou essa porta aberta, podendo ser estabelecidos diferentes processos típicos para responder adequadamente aos pedidos das partes e tutelar situações diversas: "L'opportunità di predisporre forme differenziate di tutela per specifiche situazione soggettive, è oggetto di una vautazione astratta da parte del legislatore che reputa esistere, per determinate materie, l'esigenza di offrire alla parte la possibilità di utilizzare forme processuali diverse da quelle previste nell'ordinario processo di cognizione. Si pensi al rito speciale per le controversie di lavoro, ai procedimenti monitori e ad altri procedimenti speciali finalizzati al soddifacimento di situazioni che il legislatore ritiene, come dicevo, essere bisognose di una tutela differenziata" (Ferruccio Tommaseo, I provvedimenti d'urgenza: struttura e limiti della tutela anticipatoria, p. 131). 
pessoal das partes. Pode ser apresentada oposição no procedimento documental, oportunidade na qual o juiz poderá proferir a sentença de procedência com reserva ou seja, inicia-se o procedimento executivo provisório com a discussão de cunho ordinário em outro processo.

No processo monitório, a análise consiste apenas na verossimilhança das alegações do demandante. Caso o demandado não conteste, emite-se a ordem executiva e inicia-se o procedimento executivo. $\mathrm{O}$ único meio de defesa do demandado é a oposição e, se ela ocorrer, acaba o procedimento monitório e tem início o procedimento ordinário.

É interessante que a tutela diferenciada se aproxime de um procedimento específico das tutelas de urgência, já que a flexibilização do procedimento está ligada à antecipação da cognição. Notamos também um processo de cognição sumária não urgente (no caso da tutela de evidência) e mesmo uma aproximação com o processo de execução (no caso das monitórias). Em síntese, a característica principal entre todos esses procedimentos é a sumarização na cognição que, em muitas situações, cria um procedimento específico para não ferir direitos e garantias constitucionais.

No sistema processual brasileiro, pode-se afirmar que grande parte das tutelas diferenciadas estão positivadas, ou seja, encontram previsão legal. As tutelas de urgência estão no capítulo das cautelares e nos arts. 273 e 461, que preveem a antecipação de tutela. $\mathrm{O}$ procedimento monitório está previsto no art. 1.108 do CPC e os demais em dispositivos específicos.

A única espécie de tutela jurisdicional diferenciada não prevista no nosso ordenamento jurídico é a tutela de evidência, que ainda está sendo discutida no projeto do novo Código de Processo Civil.

\subsubsection{Limitação da cognição: sumarização da atividade cognitiva do juiz}

Conforme Kazuo Watanabe, ${ }^{32}$ a atividade cognitiva pode ocorrer no plano horizontal - em extensão das matérias conhecidas - ou vertical - em relação à profundidade.

A cognição exauriente, em que o juiz analisa em profundidade todas as questões postas pelas partes, está intrinsecamente ligada à ideia de proteção do jurisdicionado e

32. Cf. Kazuo Watanabe, op. cit. 
do princípio geral da segurança jurídica, que para o constitucionalista português Gomes Canotilho é

[...] confiar em que aos seus actos ou às decisões púbicas incidentes sobre seus direitos, posições ou relações jurídicas alicerçados em normas jurídicas vigentes e válidas por esses actos jurídicos deixados pelas autoridades com base nessas normas se ligam os efeitos jurídicos previstos e prescritos no ordenamento jurídico. ${ }^{33}$

Em um primeiro momento pode-se imaginar que a cognição exauriente só ocorre nos processos ditos ordinários, em que há uma sequência fixa de atos a serem seguidos pelos jurisdicionados e pelo julgador, realizando a instrução probatória e dando amplo direito de as partes se manifestarem. No entanto, a cognição exauriente ocorre também nas ações procedimentalmente sumárias, por exemplo: nas ações do procedimento sumário (art. 275 do CPC) e dos procedimentos do juizados especiais (Lei 9.099/1998). A cognição nesses procedimentos é plena e exauriente, porque a simplificação do procedimento não significa que haverá limitação do contraditório, da ampla defesa e do devido processo legal.

O processo ordinário, que é previsto no capítulo I do CPC e considera todos os princípios processuais - contraditório, ampla defesa, isonomia e devido processo legal -, seria o procedimento ideal a ser utilizado pelos jurisdicionados e pelo próprio Estado. Ele garantiria plena defesa aos seus cidadãos, atingindo de maneira mais eficiente a pacificação social. ${ }^{34}$ Em contrapartida, o processo de cognição sumária se desenvolve para fornecer ao juiz os elementos de cognição suficientes acerca de uma situação para que seja outorgada a tutela. Dependendo da situação e do problema posto, o grau de cognição é maior ou menor, mas sempre se trata de uma cognição "incompleta". 35

33. José Joaquim Gomes Canotilho, Direito constitucional e teoria da constituição, p. 257.

34. "Nesse cenário de equilíbrio entre o poder coercitivo do Estado juiz e a observância e cumprimento de regras de proteção dos cidadãos que se submeterão aos seus comandos imperativos, o procedimento comum ordinário desponta como método ideal de prestação de tutela jurisdicional em face de crises que demandam atividade cognitiva e declaratória de direitos pelo juiz - crises de certeza, de inadimplemento ou de direito potestativo -, assegurando que o indivíduo somente sofrerá atos invasivos de sua esfera pessoal, patrimonial ou jurídica a partir da execução do comando judicial emanado de cognição plena da relação de direito subjetivo entre os sujeitos processuais, construída com a efetiva participação dos interessados no contraditório, em observância ao devido processo legal. O procedimento ordinário constitui paradigma do processo justo e équo" (Alex Costa Pereira, Tutela sumára: a estabilização da tutela antecipada e sua adequação ao modelo constitucional do processo civil brasileiro, p. 31).

35. Elio Fazzalari, Istituzioni di Diritto Proessuale, p. 169. 
Preliminarmente, o fato de a cognição do processo ser exauriente não significa que o juiz chegará a um grau de certeza sobre o direito da parte; quando muito, chegará a uma certeza do fato narrado, ou seja, terá certeza apenas das versões da história que lhes contaram. Calamandrei abordou esse assunto na década de 1950, afirmando que a busca pela verdade real é impossível de se alcançar, pois as provas produzidas pelas partes no processo não passam de mera verossimilhança e que o conjunto dessas provas foi suficiente para convencer o julgador a outorgar a tutela jurisdicional. ${ }^{36}$

Essa insegurança que muitas vezes habita o sentimento do juiz ao proferir uma decisão baseada em cognição sumária deriva de uma ideia cartesiana de método. Para evitar o máximo de prejuízo às partes, o juiz deve seguir todas as regras prestabelecidas e a forma, ou seja, o procedimento ordinário, pois somente nesse procedimento que a cognição é plena e exauriente. Daí a razão de a ciência processual rejeitar a verossimilhança como suficiente para o proferimento da decisão, tornando a busca pela verdade um objetivo a alcançar, mesmo sendo ele inalcançável. ${ }^{37}$

A cognição sumária pode ser dividida em parcial ou superficial. ${ }^{38}$ A primeira ocorre quando não foram debatidas todas as questões postas nos autos; a segunda, quando não foi dada às partes a oportunidade de produção de todos os meios de prova.

A cognição parcial configura-se nos processos em que não é permitida a produção de determinadas provas por imposição legal, por exemplo, o mandado de segurança,

36. Piero Calamandrei, Verità e verosimiglianza nel processo civile, Rivista di Diritto Processuale. vol. X, p. 164-192. Ainda sobre a questão da certeza no processo, discorre Marinoni: "Não existe verdade, pois esta se encontra no campo do impossível. A verdade varia de acordo com a subjetividade de cada um. A certeza seria a manifestação subjetiva de uma pessoa a respeito de um dado ou de um acontecimento, de modo que a verdade poderia surgir para esta pessoa, mas não para os utros ou para todos. Esta certeza, contudo - mesmo porque a subjetividade do próprio sujeito cognoscente pode mudar -, não existe nem existirá como absoluta, sequer àquele que em um dia a afirmou. Toda certeza, pois, não passa de mera probabilidade. O juiz, entretanto, deve procurar encontrar, por assim dizer, a 'certeza do caso concreto', a certeza acerca da afirmação de um fato. Falamos em certeza sobre a 'afirmação' porque o fato não pode ser qualificado de verdadeiro ou falso. O fato só adquire significação no mundo cultural ou jurídico a partir do momento em que é afirmado. A respeito da afirmação do fato, portanto, é que o juiz deve formar sua convicção de "certeza" (Luiz Guilherme Marinoni, Tutela antecipatória e julgamento antecipado: parte incontroversa da demanda. p. 52).

37. "No fundo, como mostra um dos mais eminentes filósofos contemporâneos (Hans-Georg Gadamer, Verdad y Método, tradução espanhola de 1988, p. 336-353), a aversão que a ciência processual tem por todas as formas de juízos fundados em simples verossimilhança é fruto da herança cartesiana, com sua conhecida desconfiança contra toda e qualquer espécie de 'prejuízos', contra, portanto, a autoridade e a tradição. Dir-se-ia, talvez com algum exagero, que a universalização da ordinariedade - desenterrada da velha actio dos juízos privados romanos - é o fruto mais eminente da ilustração, no domínio do Direito Processual" (Ovídio Araújo Baptista da Silva, Decisões intelocutórias e sentenças liminares, in: , Da sentença liminar à nulidade da sentença, p. 10).

38. Cristiano Rodrigo Del Debbio, op. cit., p. 40. 
em que se exige que o jurisdicionado junte à inicial todos os documentos necessários para a apreciação da questão liminarmente e que, logo após prestadas as informações da autoridade impetrada, o processo já seja julgado. Não é dada às partes a possibilidade de se percorrer o mesmo caminho do procedimento ordinário. Pelo contrário, já foi proposto pelo legislador um modelo de cognição sumária típico, em que devem ser demonstrado pelas partes a certeza e liquidez do pedido logo na petição inicial.

Já a cognição superficial ocorre no plano horizontal. Ou seja, ela pode ser limitada de forma horizontal, pois dependente de atos posteriores do processo ordinário (é o caso da tutela antecipada e da tutela de evidência) ou superficial, pois, mesmo que realizadas todas as etapas do processo, há uma imposição legal para restringir a matéria que será apreciada pelo juízo (é o caso da cautelar e das ações possessórias).

A sumariedade na cognição está profundamente relacionada à sua qualidade - não que a cognição sumária seja de qualidade inferior, mas isso diz respeito à menor observância das garantias processuais. ${ }^{39}$ Essa qualidade da cognição será aferida no próprio processo e, quanto maior for o respeito às garantias processuais, maior será a qualidade da cognição, mesmo mantendo a sua característica sumária.

Como é sabido, o tempo é um fator importante na condução do processo. É necessário um determinado período para apreciação do pedido formulado pela parte, para só então entregar (ou negar) a tutela jurisdicional. O processo, por mais célere que seja, nunca será imediato, daí ser comum a afirmação entre os doutrinadores de que o tempo atua a favor de quem não tem razão. A sumarização da cognição da tutela diferenciada busca diminuir esse fator temporal sem acabar com ele, obviamente, mas distribuí-lo de maneira equânime: ${ }^{40}$

39. Esse tema - como equilibrar a tutela diferenciada com os princípios processuais - será tratado no quarto capítulo deste trabalho. Sobre o assunto, ver o entendimento de Alex Costa Pereira em sua tese de doutorado: "Ao contrário do que intuitivamente se pode imaginar, essa cognição sumária não implica necessariamente uma atividade lógica menos racional acerca do objeto litigioso pelo juiz integrante da relação jurídica processual, neste caso por figurar superficial. Na verdade, como contraposição à cognição plena e seu modelo procedimental participativo predeterminado pelo legislador, o elemento central e identificador da cognição sumária é a outorga dos atos de cognição - e respectiva participação das partes - à discricionariedade do magistrado, sem tipificação prévia prevista em lei. Assim, deve-se entender que a tutela sumária corresponde a uma cognição, também sumária, que reflita em relação à cognição plena, uma inferioridade relativa às garantias do processo, e não compulsoriamente à qualidade lógica da atividade cognitiva desempenhada no processo" (Alex Costa Pereira, op. cit., p. 47).

40. "A questo fine le cognizione sommarie non cautelari conducono ad un accoglimento anticipato, totale o parziale, e rimovibile, della domandadi tutela, che il giudice può pronunciare solo se le prove lo convicono del fondamento, totale o parziale, della domanda" (Luigi Montesano, 
Em vez de atribuí-lo totalmente ao demandante, o processo favorecerá a parte que tiver de provar a existência de seu direito ou de sua defesa. Se interessa ao demandante provar os fatos constitutivos de seu direito, contra ele deve correr o tempo necessário para produção dessa prova. Da mesma forma, se interessa ao demandado demonstrar os fatos impeditivos, modificativos ou extintivos da pretensão inicial, então é ele quem deve suportar o tempo para essa prova: "ao autor não pode ser imposto o peso do tempo que serve unicamente ao réu". ${ }^{41}$

Por isso, essa divisão do tempo em um novo processo (caso em que as demais questões somente serão apreciadas em um novo processo se proposto pelo demandado) deve ser bem elaborada para evitar que prejudique ainda mais o seu andamento, levando a discussões desnecessárias sobre o que foi provado e analisado na fase de cognição sumária.

Tratando especificamente da limitação da cognição, conforme Rodrigo Del Debbio, ${ }^{42}$ existem diversas técnicas de sumarização da cognição que são utilizadas pelo legislador, tanto no plano horizontal quanto no plano vertical. No plano vertical, a cognição limita o objeto de conhecimento do juiz, e não há um aprofundamento das questões postas pelas partes por parte do juízo. Trata-se de análise de um juízo de probabilidade e verossimilhança. ${ }^{43}$

A cognição sumária é utilizada especialmente nos processos urgentes, sejam eles cautelares ou não, mas também em procedimentos diferenciados, em que a tutela buscada em juízo seja diferente e demande um procedimento não ordinário. Também é utilizada em situações de urgência no procedimento ordinário, como, por exemplo, na antecipação da tutela, prevista no art. 273 do CPC.

Segundo Kazuo Watanabe, a sumariedade na cognição decorre de dois fatores: da urgência da tutela pleiteada ou de escolha legislativa. A urgência da tutela implica aquelas situações que não podem aguardar o final do processo de conhecimento para serem deferidas, sob pena de a tutela não ser mais necessária, e também está ligada à necessidade de proteção imediata de um bem ou até mesmo do processo. É o que ocorre, por exemplo, nas tutelas cautelares.

Strumentalità e superficialità della cognizione cautelare, Rivista di Diritto Processuale, vol. 54, n. 2, p. 309-316).

41. Cristiano Rodrigo Del Debbio, op. cit., p. 63.

42. Cf. Cristiano Rodrigo Del Debbio, op. cit.

43. Cf. Kazuo Watanabe, op. cit., p. 145. 
Sobre as tutelas cautelares, é interessante notar que há sumarização da cognição por dois fatores: para prevenir o eventual dano pela demora na prestação jurisdicional, assegurando a eficácia do provimento da tutela ordinária que será proposta; quando constatada pelo juiz a urgência da tutela pleiteada. ${ }^{44}$ Ainda, como exemplo de cognição sumária em razão da urgência, há a tutela antecipada e o mandado de segurança.

$\mathrm{Na}$ Itália o procedimento da tutela antecipada também é de cognição sumária, em razão, principalmente, da limitação temporal e do procedimento. ${ }^{45} \mathrm{~A}$ cognição é sumária pois o juízo de cognição não é definitivo já que parcial ou superficial. A parcialidade muitas vezes ocorre porque o juiz somente pode avaliar o pedido com os elementos analisados nos autos, dada a urgência requerida. Por outro lado, a superficialidade ocorre por uma limitação no procedimento que não permite ao juiz analisar profundamente as questões ali postas, já que não são necessárias para a solução do processo. ${ }^{46}$

Há ainda a possibilidade de sumariedade na cognição por escolha legislativa, caso da tutela possessória, da tutela de evidência, da monitória. Trata-se de escolha legislativa, pois o legislador, com fundamento na matéria levada a juízo, entende que não seja questão complexa que demanda um procedimento ordinário de cognição plena e que bastaria essa cognição superficial do julgador para o deferimento da tutela.

Interessante notar que em ambas as hipóteses foi analisado o mérito da causa. $\mathrm{Na}$ primeira, foi necessário fazer um juízo prévio de verossimilhança e verificar se de fato tratava-se de algo urgente e se havia o risco de perecimento do direito. Na segunda hipótese, as situações de direito material não demandam cognição plena, escolha esta feita previamente pelo legislador - caberá ao juiz verificar se é o caso concretamente. ${ }^{47}$

44. Cf. Luigi Montesano, Strumentalità e superficialità della cognizione cautelare, Rivista di Diritto Processuale, vol. 54, n. 2, p. 310. Para o autor, se constatado o periculum in mora o juiz deve conceder a tutela pleiteada, única e exclusivamente nesse critério.

45. "In ogni caso, e nonostante che il provvedimento propriamente anticipatorio sia adottato all'interno di un ordinario o speciale processo a cognizione piena, è certo che alla cognizione del provvedimento propriamento anticipatorio deve essere riconosciuta natura sommaria (o perché non completa e non definitiva, o perché non formale) e che al relativo procedimento va riservata la qualificazione in termini di sub-procedimento sommario" (Antonio Carratta, Profili sistematici della tutela anticipatoria).

46. "Il primo veniva individuato come procedimento sommario a cognizione piena, i secondi come procedimenti speciali a cognizione sommaria, in quanto l'accertamento compiuto dal giudice era o nondefinitivo (come nel caso della sentenza provvisoriamente esecutiva) o parziale (come nel caso delle condanne con riserva) o superficiale (come nel caso del procedimento ingiutivo)" (idem, ibidem).

47. "Em suma, nos processos sumários cautelares e não cautelares, a sumariedade da cognição abrange o próprio mérito da causa. Entre a perfeição e a celeridade, o legislador procurou privilegiar esta 
Da primeira situação, podemos citar o exemplo da sentença proferida com base em cognição sumária nos casos das cautelares em que o julgador analisa superficialmente a questão e outorga a tutela com base apenas nos elementos trazidos também de forma superficial. É proferida uma sentença "provisória”, que será confirmada (ou não) quando da instauração do processo principal, oportunidade na qual serão analisadas em profundidade todas as questões postas pelas partes.

É importante diferenciar o que ocorre no Brasil do que ocorre na Itália, pois país que influencia enormemente nosso sistema processual. Na Itália, como no Brasil, há a tutela cautelar. ${ }^{48}$ Contudo, as soluções e a natureza da sentença são diversas. Quando a tutela cautelar italiana é proferida, é oportunizado à parte demandada ajuizar a ação principal para a discussão aprofundada da questão posta na cautelar. Caso não seja ajuizada a ação no prazo, a sentença torna-se definitiva, formando coisa julgada material. No Brasil, a tutela cautelar é concedida ao demandante e este tem o prazo de trinta dias para ajuizar a ação "principal” (art. 806 do CPC). Se essa ação não for proposta no prazo estipulado pela lei, cessa a eficácia da medida cautelar.

Na tutela cautelar não há uma limitação de quantas questões serão analisadas pelo juiz, mas da profundidade da análise de referidas questões: é emitido um juízo de probabilidade, e não de certeza. Isso porque a tutela cautelar é proferida buscando acautelar uma situação urgente que causará um dano premente às partes ou ao processo se não deferida.

A mesma limitação ocorre em situações de antecipação de tutela: a limitação da cognição ocorre no plano vertical, em que o juiz somente irá apreciar as questões superficialmente postas pelas partes, para somente depois de realizada a cognição plena ser proferida uma sentença.

Diferentemente do caso da tutela cautelar, inicialmente não é proferida uma sentença que precisará ser confirmada. Nos procedimentos que preveem a tutela antecipada, não é proferida uma sentença, mas uma decisão interlocutória.

A sumariedade pode residir ainda no próprio direito material, por exemplo, nas discussões possessórias, ações de depósito, levando à conclusão de que é o direito

última, mas em contrapartida deixou de conferir a autoridade de coisa julgada material ao conteúdo declaratório assentado em cognição sumária" (Kazuo Watanabe, op. cit., p. 164).

48. Entendida, para os fins desta dissertação, como tutela diferenciada, haja vista a sumarização da cognição. 
material que define a profundidade da cognição, mostrando-se totalmente desnecessária uma cognição aprofundada em algumas situações.

Outra característica do processo de cognição sumária é que em muitas situações o contraditório é postecipado, ou seja, o réu somente irá exercer o contraditório após a manifestação do juiz. Consequentemente, como o contraditório realiza-se em um momento posterior, a cognição é sumária no sentido vertical, porque o juiz somente teve acesso aos fatos narrados pelo autor, sem ter conhecimento de todos os fatos narrados. A sumariedade surge daí, da parcialidade dos fatos levados a juízo. ${ }^{49}$

Há ainda a hipótese em que o juiz determina a apresentação da contestação antes de dar o provimento urgente (isso ocorre muito em casos de tutela antecipada). A esse respeito, podemos afirmar que a cognição é sumária não porque foi parcial, mas, sim, porque foi superficial, pois apesar de o réu ter a oportunidade de apresentar contestação ainda não se realizou a cognição plena.

Entendemos que há dois grandes tipos de limitação da cognição: cognição sumária porque superficial e a cognição sumária porque foi parcial. O primeiro tipo, em razão da matéria e do próprio procedimento, por exemplo, no caso das ações possessórias. O segundo agrupa os casos de antecipação da tutela e da cautelar, medidas urgentes que, em razão da própria urgência do pleito, não puderam ser aprofundadas.

Na tutela diferenciada há os dois tipos de limitação - sumária, porque superficial em razão da urgência do direito pleiteado ou da evidência do direito da parte; parcial, porque o processo ainda irá se desenvolver.

\subsubsection{Sumarização do procedimento $\times$ sumarização da cognição}

Como analisamos, a característica central das tutelas diferenciadas é a sumarização na cognição tanto no sentido vertical quanto no horizontal, dependendo do procedimento adotado. Tais tutelas encaixam-se na necessidade da sociedade atual de agilidade na prestação juridicional. Assim, pretendendo essa efetividade da tutela jurisdicional, os legisladores de diversos países têm buscado soluções tanto para acelerar o procedimento quanto para acelerar a cognição do juiz.

Essa aceleração do procedimento não significa, necessariamente, que a cognição será sumária - é o caso dos juizados especiais da Lei 9.099/1995 e do procedimento

49. Andrea Proto Pisani, La tutela sommaria in generale e il procedimento per ingiunzione nell'ordinamento italiano, Revista de Processo, vol. 23, n. 90, p. 22-35. 
sumário, em que as etapas do processo são simplificadas se considerado o procedimento ordinário, mas a cognição é plena. Trata-se apenas de uma sumarização do procedimento.

Em compensação, temos a sumarização da atividade cognitiva do juiz, que pode ocorrer em processos de cognição plena e exauriente (caso da tutela antecipada e da tutela de evidência), como também em procedimentos típicos (ações, possessórias, mandado de segurança). Trata-se aqui da sumarização da cognição.

Essas duas espécies de sumarização não se confundem, pois na sumarização do procedimento ficam preservadas todas as garantias constitucionais das partes, principalmente com relação ao contraditório e à ampla defesa. Tanto que tais decisões adquirem força de coisa julgada. Por outro lado, na hipótese da sumarização da cognição, que nada mais é que a tutela diferenciada, há uma minoração das garantias constitucionais, sobretudo o contraditório e a ampla defesa, o que impossibilitaria tais decisões de adquirirem força de coisa julgada. ${ }^{50}$

Especialidade e sumariedade não se confundem. A especialidade está ligada ao procedimento, enquanto a sumarização está ligada à cognição, aos pontos que serão levados ao conhecimento do juiz.

Assim, a sumarização pode estar ligada ao rito processual ou da cognição. A sumarização do procedimento pode ocorrer em procedimentos de cognição sumária, mas também em procedimentos de cognição plena, por exemplo, no caso dos juizados especiais. O procedimento é sumário, mas a cognição é plena.

Dessa forma, a sumariedade formal é apenas "resultado da aceleração da prática dos atos processuais" ${ }^{21}$. O procedimento é sumário pois as fases são limitadas e, contudo, a cognição é plena. Por exemplo, um procedimento no Juizado Especial Cível ou procedimento sumário são de cognição plena. A cognição sumária não está necessariamente ligada à especialidade ou sumariedade do procedimento, mas à profundidade da cognição. ${ }^{52}$

50. Cf. José Carlos Barbosa Moreira, Tutela de urgência e efetividade do direito, in: Temas de direito processual, p. 91.

51. Luiz Guilherme Marinoni, $\mathrm{O}$ direito à efetividade da tutela jurisdicional na perspectiva da teoria dos direitos fundamentais, Gênesis: Revista de Direito Processual Civil, n. 28, p. 217-432.

52. "O procedimento de cognição sumária (essa é apenas uma das espécies da cognição em sentido material) não permite o conhecimento aprofundado do objeto cognoscível (verossimilhança), ao passo que o procedimento formalmente sumário (art. 275 e ss. CPC) sempre possibilita o conhecimento aprofundado dos fatos litigiosos, embora em um tempo inferior àquele que seria gasto pelo procedimento ordinario - diante da aceleração dos atos processuais" (idem, ibidem). 
A característica primordial da limitação da cognição é a limitação do objeto cognoscível do juiz, e isso pode ocorrer de duas formas: restringindo as matérias e questões que poderão ser levadas a juízo; limitando as alegações que o réu pode apresentar na defesa. ${ }^{53}$

A tutela de sumarização do procedimento, como demonstramos, nem sempre se caracteriza pela urgência, podendo decorrer da necessidade de se prever um rito diferenciado para uma situação de direito peculiar. No mesmo sentido, não necessariamente a sumarização da cognição decorre da urgência do direito pleiteado. Vemos isso no caso de tutela de evidência, de questões possessórias, de monitória, de consignação em pagamento e mesmo de julgamento antecipado, como previsto no art. 333 do CPC. Também existem situações que demandam uma sumarização da cognição em razão da urgência, casos da tutela antecipada e cautelar e do mandado de segurança.

Podem existir situações ainda nas quais a sumarização do procedimento e a sumarização da cognição se confundam, ou seja, em que há um procedimento especial, sumário, com fases menos demarcadas, e nas quais, em razão dessa própria sumarização do procedimento, ocorra a sumarização da cognição. É o caso do procedimento monitório, cujo início corresponde a uma fase documental em que, se o réu não embargar, torna-o um título executivo, o contraditório é mitigado e corre como uma execução. Por outro lado, caso o réu embargue, o processo passa a ter uma cognição plena.

O procedimento sumário italiano é também de cognição sumária, mas adaptado a um rito especial para proporcionar essa cognição sumária. As formas de tal procedimento são simplificadas para que a cognição seja realizada de forma sumária, sem prejudicar o contraditório e a ampla defesa. ${ }^{54}$

53. Logicamente, isso não impede que o réu ou o autor levem essas mesmas questões a juízo através de outra ação e cognição plena. É o caso, por exemplo, das ações possessórias em que não é permitido ao réu discutir questões de propriedade, cabendo a ele ajuizar a ação correta para a discussão dessa questão.

54. "La sommarietà del processo, dunque, assume una duplice valenza e si riferisce alla forma semplificata del procedimento e al modo in cui si forma il connvincimento del giudice, che non è fondato su una cognizione plena. Ne deriva che si ha a che fare con processi sommari non solo quando manchi la preventiva instaurazione del contraddittorio nei confronti della controparte (e, dunque, con cognizione dei soli fatti costitutivi della domanda), ma anche quando essa si realizzi con modalità processuali più compendiosoe ed abbreviate, senza, cioè, la normale articolazione dei processi a cognizione piena ed esauriente del giudice sui fatti giuridicamente rilevanti prima di pronunciare la decisione, ciò comporta che la pronncia del provvedimento non pressuppone come per la pronuncia della sentenza - la formazione del prudente convincimento del giudice (art. 116 CPC). E tuttavia, per quanto già detto, e cioè la stretta correlazione fra struttura e funzione del processo sommario, non possono essere indifferente le scelte che in concreto opera il legislatore 
A técnica do procedimento monitório visa evitar o desenvolvimento do juízo de cognição plena. Somente será desenvolvido se as partes assim optarem. As vantagens são diversas para o sistema, porque se evita, a priori, um procedimento custoso e longo, outorgando a tutela jurisdicional rapidamente a quem foi procurar o Judiciário, resolvendo o problema de forma pacífica.

Entretanto, essa técnica poderia levar a um prejuízo para o réu, pois este tem o contraditório sacrificado, já que será realizado somente se ele assim decidir. Não enxergamos qualquer problema nessa técnica do conraditório diferido, já que o réu poderá exercer seu direito de defesa se assim desejar e entender que é o mais correto.

No Brasil, deve-se mudar a mentalidade litigiosa que pensa da seguinte forma: o réu deve contestar, o réu deve se defender, ainda que de forma protelatória e sem que existam quaisquer argumentos que fundamentem a sua pretensão. Nessas hipóteses, é preferível tentar chegar a um acordo com a parte autora a ficar protelando um processo cujo resultado será fatalmente a procedência da ação.

Depois de feita a análise e estudadas as diferenças entre a cognição no conhecimento e na cognição no procedimento, resta a seguinte pergunta: um procedimento de cognição sumária (tanto procedimentalmente quanto na própria cognição) basta por si?

Marinoni é claro ao afirmar que, em razão da garantia constitucional do devido processo legal, é sempre necessário um processo de cognição exauriente, porque as partes têm o direito de controverter os fatos ali postos, debater sobre as teses jurídicas, enfim - elas têm direito a uma cognição aprofundada. ${ }^{55}$

Lógico que existe um receio de a tutela de cognição sumária ser mais valorizada diante de um processo de cognição aprofundada, por tirar do procedimento ordinário a aura de único e verdadeiro instrumento de justiça. ${ }^{56}$ Com todo respeito aos

sia con riferimento alla semplificazione delle forme processuali, che con riferimento alla qualità della cognizione del giudice sui fatti di causa e dei risultati del loro accertamento" (Antonio Carrata, Strutura e funzione nei procedimenti giurisdizionali sommari, in: (org.), La tutela sommaria in Europa: studi).

55. "O processo principal é necessidade decorrente do direito à adequada cognição da lide.As partes, efetivamente, têm o direito de controverter amplamente suas razões, razão pela qual nenhum processo onde a cognição é sumária pode ser autônomo" (Luiz Guilherme Marinoni, Antecipação da tutela, p. 124).

56. Cf. Edoardo Ricci, Per una efficace tutela provvisoria ingiunzionale dei diritti di obbligazione nell'ordinario processo civile, Rivista di Diritto Processuale, ano XLV, n. 4, p. 1021-1036. Afirma o autor: "Ciò deve essere tenuto presente, come antidoto per una ricorrente timore: quello di una 'sommarizzazione' della tutela giurisdizionale dei diritti di obbligazione, parallela ad una svalutazione del processo ordinario come strumento di giustizia. Che la tutela provvisoria 
doutrinadores que compartilham tal receio, ele não se justifica. Sempre existirão problemas e questões muito complexas que não poderão nunca ser resolvidos em cognição sumária. O juiz quando muito poderá antecipar os efeitos da sentença, mas, provavelmente, se a questão de fato é intrincada e merece maior aprofundamento, este ocorrerá, respeitando os princípios processuais constitucionais e, por fim, entregando o bem da vida procurado.

sommaria ingiunzionale possa in qualche misura disincentivare il ricorso al processo ordinario (o possa quanto meno la sua coltivazione sino alla decisione di merito) è ovvio; e sul tema si dovrà tornare tra poco, essendo proprio questo uno degli aspetti positivi della innovazione suggerita" (idem, ibidem). 


\subsubsection{Celeridade}

Não há dúvida de que uma das características da tutela diferenciada é a celeridade, e isso ocorre, em grande parte, pela própria sumarização da cognição. A questão de a sumarização da cognição ser colocada em primeiro plano e os processos de cognição plena serem utilizados apenas quando necessários está intrinsecamente ligada à ideia de eficiência que o Estado tanto tem buscado para garantir aos cidadãos uma justiça que não tarda nem falha. ${ }^{57}$ Mesmo porque um processo de cognição plena e exauriente não significa, necessariamente, que se chegará a uma certeza absoluta dos fatos narrados; atinge-se, no máximo, um grau elevado de verossimilhança em que os fatos são tidos por verdadeiros.

Dessa forma, o eterno dilema entre segurança e efetividade deve levar esse fator em consideração. Muitas vezes, é necessário um processo mais célere, que será mais efetivo do que um processo muito longo e demorado, que não vai chegar a um resultado satisfatório de certeza e que entregará uma tutela jurisdicional a destempo.

Todo processo tem um tempo mínimo necessário para o seu desenvolvimento. Ocorre que, atualmente, com o grande crescimento da sociedade de consumo e com o amplo acesso à internet, a população (muito maior em números, já que também vivemos uma onda de litigiosidade) passou a exigir respostas imediatas a seus problemas, e nem o processo de cognição ordinária acompanha esse ritmo nem o Estado proporciona os meios suficientes para outorgar a tutela jurisdicional. ${ }^{58}$ Por isso, diante da crise do Poder Judiciário que vivemos e para ajudar a regular essas novas relações e essa nova sociedade, o estudo da tutela diferenciada é essencial.

57. "Certo lo scopo perseguito dal legislatore in questo progressivo spostamento del baricentro della tutela giurisdizionale dei diritti verso la cognizione sommaria è quello rendere i processi più rapidi e snellì a fine di riconquistare quel minimo di efficienza che ogni Stato civile dovrebbe assicurare ai suoi cittadini nell'amministrazione dela giutizia" (Andrea Graziosi, La cognizione sommmaria del giudice civile nella prospettiva delle garanzie costituzionali, Rivista Trimestrale di Diritto $e$ Procedura Civile, vol. 63, n. 1, p. 163-174).

58. Ovídio Araújo Baptista da Silva, Celeridade versus economia processual, in: liminar à nulidade da sentença, p. 225. Da sentença 


\section{PRINCÍPIOS PROCESSUAIS E ESTABILIZAÇÃO DA TUTELA DIFERENCIADA}

\subsection{Princípios processuais sob a óptica da estabilização}

O procedimento ordinário - aqui entendido como aquele de cognição plena e exauriente - foi eleito como o procedimento que sempre deverá ser utilizado. Somente em casos excepcionais se utilizam outros procedimentos. Ao assim agir, o legislador definiu a segurança jurídica como o valor máximo do nosso sistema processual. No decorrer da história, porém, isso visivelmente colide com os valores de celeridade e efetividade.

A tutela diferenciada, no sentido de cognição sumária, não é a regra: ela supostamente não elegeria o valor segurança jurídica, mas o da efetividade e da duração razoável do processo. Essa talvez seja a impressão à primeira vista, no entanto, e em momento algum o fato de tratar-se de tutela diferenciada significa que o valor da segurança necessariamente seja sacrificado para se atingir o valor da efetividade. $\mathrm{O}$ que se busca é um equilíbrio entre esses princípios processuais constitucionais para que a tutela seja entregue da forma mais célere possível sem prejudicar o contraditório e a ampla defesa.

A tipicidade sem dúvida é essencial para atingir o escopo da tutela diferenciada e até mesmo trazer maior efetividade. Contudo, ela possui um efeito perverso, pois esses instrumentos novos de aceleração do processo sempre são construídos pensando no autor, nunca no réu e em sua defesa. É essencial também que esses instrumentos típicos sejam concebidos em consonância com os principios processuais, já que não basta o resultado do processo em tempo célere se ele não foi um processo justo. ${ }^{59}$

59. Barbosa Moreira faz um importante alerta sobre esse tema: "Cabe agora uma palavra de advertência para alguns riscos a que está sujeito o pensamento ordenado à efetividade do processo. Consiste o primeiro na tentação de arvorar a efetividade em valor absoluto: nada importaria senão tornar mais efetivo o processo, e nenhum preço seria excessivo para garantir o acesso a tal meta. É esquecer que no direito, como na vida, a suma sabedoria reside em conciliar, tanto quanto possível, soliitações contraditórias, inspiradas em interesses opostos e igualmente valiosos, de forma que a satisfação de um deles não implique o sacrifício total de outro" (José Carlos Barbosa Moreira, Efetividade do processo e técnica processual, Revista de Processo, vol. 20, n. 77, p. 171. No mesmo sentido, posiciona-se Bedaque: "Evidentemente, não se pode eleger a segurança jurídica e as garantias do processo como valores absolutos. Nessa área da atividade humana, como 
Desse modo, é de rigor que haja tratamento isonômico entre as partes do processo. ${ }^{60}$ Não se nega que é necessário revisitar esses conceitos para adaptá-los à realidade e ao significado do processo no presente, mas é preciso respeitar o núcleo duro desses princípios, pois somente assim o Estado entregará uma tutela jurisdicional efetiva. $^{61}$

Nesse sentido, defende Leonardo Grecco que, para evitar qualquer violação a esse núcleo duro, o legislador deve prever um procedimento adequado para que a sumarização na cognição ocorra sem prejudicar tais princípios processuais mínimos. ${ }^{62}$ Segundo o autor, essa previsão deve decorrer via lei expressa, e não ficar a cargo da flexibilização do juiz, o que poderá levar a um processo de surpresas (muitas vezes desagradáveis) que não coaduna com a ideia de segurança jurídica. ${ }^{63}$

Essa é, sem dúvida, a grande preocupação do processualista contemporâneo. Compatibilizar a urgência com o tempo mínimo que o

de resto, em quase tudo na vida, o relativismo predomina. O culto exagerado aos princípios pode levar ao enrijecimento do processo, fenômeno igualmente não desejado. Mas também não vamos adotar solução diametralmente oposta, considerando a rapidez, com a consequente sumariedade da cognição, como único valor a ser perseguido no processo. Temos de refletir bem sobre o alto preço a ser pago por essa solução extremada, que pode comprometer a segurança oferecida pelo instrumento estatal de solução de controvérsias. O processo justo (equo) não é apenas aquele que permite soluções rápidas. Esse é apenas um dos valores, mas há outros tão importantes quanto. A excessiva sumarização do processo de conhecimento, como técnica genérica de luta contra o tempo, pode comprometer de forma inaceitável as garantias de segurança. O ideal, portanto, é o quilíbrio entre os valores constrastantes do processo" (José Roberto dos Santos Bedaque, Estabilização das tutelas de urgência, in: Mauricio Zanoide de Moraes; Flávio Luiz Yarshell (orgs.), Estudos em homenagem à professora Ada Pellegrini Grinover, p. 681).

60. No mesmo sentido: “A adoção de tipos tutela diferenciada tende a favorecer o polo ativo da relação processual, na medida em que são eles concebidos precipuamento com o propósito de acelerar a prestação jurisdicional. Por isso mesmo, indispensável se torna cautela na sua adoçao, para se evitar a violação do tratamento isonômico das partes litigantes e a vulneração do princípio assegurador da paridade das armas no processo" (Donaldo Armelin, Tutela jurisdicional diferenciada, Revista de Processo, p. 46).

61. "O Estado de Direito contemporâneo, fundado sobre a supremacia dos direitos humanos e das garantias da sua eficácia concreta, entre as quais se destacam o devido processo legal, o contraditório e a ampla defesa, tem necessidade de submeter esses procedimentos à crítica da sua adequação, sob perspectiva do processo equitativo ou justo, pois essas garantias também são direitos fundamentais e esse Estado não estará cumprindo a sua promessa de tutela jurisdicional efetiva dos direitos dos cidadãos se elas não forem respeitadas ou se as decisões judiciais resultarem de procedimentos em que o juiz sofre profundas limitações na apuração da verdade e na apreciação do direito das partes" (Leonardo Grecco, Cognição sumária e coisa julgada).

62. Leonardo Grecco, op. cit., p. 3.

63. "A sumariedade da cognição deve decorrer da lei, pois isso resulta necessariamente dos valores de justiça procedimental e de equidade, ínsitos à garantia constitucional do devido processo legal (Constituição Federal, art. 5, inciso LIV). Ademais, acognição sumária, além de prevista em lei, somente se justifica para atender a valores constitucionais, como a efetividade e a celeridade, não podendo ser transformada num meio atípico e generalizado de tutela jurisdicional, que impeça o acesso à cognição plena e à obtenção de um provimento apto à formação da coisa julgada" (Leonardo Grecco, op. cit., p. 3-4). 
desenvolvimento do processo legal requer. Impedir que as garantias a ele inerentes acabem por transformar a tutela jurisdicional em promessa formal, sem qualquer utilidade prática para quem recorre à função estatal, cujo escopo é exatamente eliminar as controvérsias e alcançar a pacificação de forma eficinte, útil e eficaz. ${ }^{64}$

Pode-se ficar com a impressão de que os princípios processuais serviriam apenas para garantir direitos aos réus, mas tais princípios também garantem direitos aos autores. O direito à ampla defesa e do contraditório plena também são aplicados ao autor.

É importante ter em mente o conflito que se está buscando equilibrar. Chiovenda abordou o assunto, questionando se seria melhor apenas contar com as soluções legislativas postas de forma abstrata ou se seria melhor dar mais poderes ao juiz para que ele pudesse decidir de acordo com o caso concreto e assim tornar o processo como um meio simplificado "un mezzo potente di semplificazione processuale" 65 .

Dessa forma, não há dúvida de que é muito mais garantia conseguir chegar a um procedimento simplificado que garanta todas os direitos às partes e dê uma solução rápida e eficaz, atingindo, assim, o escopo do processo.

\subsection{Princípio da igualdade}

A análise dos princípios constitucionais processuais sob o ângulo da estabilidade da tutela diferenciada é importantíssima, uma vez que não basta outorgar a tutela se os princípios e garantias constitucionais não são respeitados.

O primeiro princípio a analisar é o da igualdade. Esse princípio, sem dúvida, é a pedra basilar do nosso sistema constitucional e do nosso Estado Democrático de

64. Cf. José Roberto dos Santos Bedaque, Tutela cautelar e tutela antecipada: tutelas sumárias e de urgência (tentativa de sistematização), p. 89. A mesma preocupação é demonstrada por Comoglio: “a) da un lato, mirano a rendere effetiva, in termini struentali, la possibilità di ricorso al giudice, per la tutela di quei medesimi diritti fondamentali, che sono 'riconosciuti' delle Costituzioni o dalle Convenzioni internazionali; b) dall'atro, identificano, in termini contenutistici, altrettanti diritti pubblici subiettivi, aventi per oggeto le condizioni minime e insopprimibili di um processo giusto (vale a direto: l'imparziliatà e l'indipendenza del giudice 'naturale' precostituito per legge; l'eguaglianza delle parti e la 'parità delle armi' nel giudizio; i poteri di azione e difesa) o, se si preferisce, e condizioni necessarie e sufficienti per una giusta risoluzione delle controversie, nell'ambito di quel giusto processo" (Luigi Paolo Comoglio, Garanzie costituzionali e "giusto processo" (modelli a confronto), Revista de Processo, n. 90, p. 101).

65. Giuseppe Chiovenda, Principii di diritto processuale civile, p. 664; Istituzioni di diritto processuale civile I, p. 87 e ss. 
Direito, e não é exclusividade brasileira, mas uma garantia prevista na maior parte dos países democráticos. Está previsto no caput do art. $5^{\circ}$ da Constituição Federal e garante tratamento igualitário entre todos os cidadãos. ${ }^{66}$

Esse princípio acaba refletindo nas demais garantias processuais e nos leva a uma óbvia conclusão: a igualdade de armas entre o réu e o autor no processo civil. É sob essa perspectiva que iremos analisar o princípio da igualdade - como respeitá-lo, tratando as partes de forma igualitária, garantindo o direito de defesa e outorgando a tutela jurisdicional.

O princípio da igualdade na perspectiva processual pode ser dividido em três momentos:

- Antes da propositura da ação - ele se verifica na própria possibilidade de propositura de ação, o acesso irrestrito ao Judiciário, esse princípio está previsto no inciso XXXV, art. $5^{\circ}$ da nossa Constituição Federal.

- Durante o processo - o princípio da igualdade é verificado através da aplicação das normas processuais de forma igual entre os litigantes, proporcionando a possibilidade de o réu defender-se amplamente e o autor apresentar as suas razões. Sendo o processo julgado após ouvida as partes e realizada ampla instrução probatória.

- Após o julgamento do processo - o princípio da igualdade também se aplica uma vez que a decisão proferida (e, consequentemente, seus efeitos) devem ter assegurada uma identidade com o resultado decisório, evitando o direito lotérico, dando as partes exatamente o que elas esperavam. ${ }^{67}$

Em um processo de cognição sumária, é possível ficar com a impressão de que o princípio da igualdade não seria respeitado, uma vez que a cognição é limitada materialmente (tanto no plano horizontal quando no plano vertical), não havendo uma análise profunda das matérias pelo juiz ou havendo um corte das matérias que podem ser levadas ao conhecimento do julgador. No entanto, cabe relembrar que essa limitação da cognição também se aplica ao réu: a técnica da estabilização da tutela diferenciada também é utilizada a favor dele quando há o julgamento antecipado de uma questão e o direito do autor já é liminarmente julgado improcedente.

66. “Art. 50. Todos são iguais perante a lei, sem distinção de qualquer natureza, garantindo-se aos brasileiros e aos estrangeiros residentes no País a inviolabilidade do direito à vida, à liberdade, à igualdade, à segurança e à propriedade, nos termos seguinte".

67. Luigi Paolo Comoglio, Tutela differenziatta e pari effettività nella giustizia civile, Rivista di Diritto Processuale, ano LXIII (seconda serie), n. 6, p. 1516. 
É o caso do art. 285- $\mathrm{A}^{68}$ do CPC, o expoente máximo de que a sumarização da cognição trabalha também a favor do réu. Referido dispositivo legal é claro ao afirmar que a ação deve ser imediatamente julgada extinta caso o pedido formulado pelo autor se mostrar insustentável ou for contra questão já sumulada. ${ }^{69}$

Muito se criticou a respeito desse dispositivo legal, chegando-se a afirmar que ele seria inconstitucional pois não permitiria a defesa do réu e a plenitude do procedimento ordinário. Contudo, não enxergamos nele inconstitucionalidade alguma. Não há qualquer violação ao direito do réu, que sequer chegou a ser citado, ou seja, não sofreu prejuízo algum, e a ação foi extinta sem sequer ele tomar conhecimento. Igualmente, não há prejuízo algum para o autor. Tratando-se a questão de direito e já se encontrando sumulada, seria um desperdício de tempo para o autor e de dinheiro público para o Judiciário levar adiante uma ação fadada ao insucesso.

Essa técnica de julgamento antecipado é utilizada no processo civil inglês, o summary judgment, em que o julgador profere uma decisão sumária extinguindo liminarmente o processo quando este se mostra sem perspectiva de êxito. ${ }^{70}$ Nesse caso também podemos falar em tutela diferenciada, já que em sede de cognição sumária o julgador já verificou que o autor não possuía os elementos necessários para a continuidade do processo e a sustentação dos seus pedidos. É a tutela sumária sendo utilizada a favor do réu.

O princípio da igualdade também pode ser analisado pela óptica de proporcionar ao réu a possibilidade de se defender no processo, dando a ele paridade de armas para a sua defesa em juízo. Isso porque, muitas vezes, a simples propositura da ação pode

68. “Art. 285-A. Quando a matéria controvertida for unicamente de direito e no juízo já houver sido proferida sentença de total improcedência em outros casos idênticos, poderá ser dispensada a citação e proferida sentença, reproduzindo-se o teor da anteriormente prolatada".

69. "Mas o processo civil não é apenas método de solução de controvérsias voltado à proteção do demandante. $\mathrm{O}$ direito evidente também pode estar ao lado do demandado, revelando-se também contraproducente o cumprimento de todas as etapas do procedimento ordinário quando a pretensão do autor da demanda contraria frontalmente regra de direito material reguladora do caso concreto. Ao analisar a petição inicial, pode o juiz, a partir de cognição sumária nos sentidos vertical e horizontal, e liminarmente, julgar a demanda improcedente dispensando a formação plena da relação jurídica processual que se daria mediante a citação do réu" (Alex Costa Pereira, Tutela sumária: a estabilização da tutela antecipada e sua adequação ao modelo constitucional do processo civil brasileiro, p. 71).

70. "Rule 56 - (a) Motion for Summary Judgment or Partial Summary Judgment. A party may move for summary judgment, identifying each claim or defense — or the part of each claim or defense - on which summary judgment is sought. The court shall grant summary judgment if the movant shows that there is no genuine dispute as to any material fact and the movant is entitled to judgment as a matter of law. The court should state on the record the reasons for granting or denying the motion". 
significar um prejuízo incomensurável ao réu (geralmente à sua imagem), e, em razão disso, o réu faz questão de contestar, apresentando as suas razões no mérito para demonstrar que o pleito do autor não se sustenta.

Dessa forma, se o Poder Judiciário autoriza que o autor proponha uma ação que possa vir a comprometer a imagem do réu em nome do princípio da igualdade ele também deve permitir uma defesa real e efetiva do réu. ${ }^{71}$ Isso ocorre muitas vezes. Imaginemos a hipótese de um processo penal: a mancha sobre a imagem do réu é incalculável, noticia-se largamente na mídia que foi ajuizada uma ação contra a pessoa, todos lembrarão do nome dela e farão um prejulgamento (conforme a ideia medieval de que “onde há fumaça, há fogo"). Mesmo que o réu seja absolvido, ninguém se lembrará desse fato.

O mesmo ocorre no processo civil. Muitas vezes o magistrado defere uma decisão liminarmente, e isso prejudica muito a imagem do réu, principalmente se o réu for uma empresa que lida com consumidor. Basta ver os recentes casos dos sites de compras Submarino.com e Americanas.com, que foram impedidos de comercializar seus produtos até a regularização de problemas em entregas das compras efetuadas. $\mathrm{O}$ dano causado à imagem das empresas já foi feito no próprio ajuizamento da ação, intensificando-se quando deferida a liminar impedindo a realização das suas atividades comerciais. $^{72}$

Ainda, podemos afirmar que o princípio da igualdade também se conforma com a sumariedade na cognição (a tutela diferenciada), uma vez que eventual provimento

71. Como afirma Guillén: "Ya vimos en otro lugar, como no es preciso recurrir a la itis contestatio para justificar la prohibición de transformar una demanda. No solamente existe un interés de defensa del demandado - ya que una alteración de la demanda le haría más difícil la adopción de una posición defensiva determinada - sino también el principio de irreiterabilidad del proceso, ya estudiado y aplicado por la doctrina de irreiterabilidad del proceso, ya estudiado y aplicado por la doctrina italiana medieval. Una transformación de la demanda produce la sustitución de una pretensión por otra; con lo que haría posible la reproducción judicial de la sustituída. Y, puede pensarse que el demandado ha sido molestado, perturbado y puesto en peligro con respecto a sus bienes y aun a su prestigio personal, prfesional en público, por medio de una actuación escrita - la demanda - que se desarolla según el principio de publicidade. El proceso puede tener, pues, por el solo hecho de haber sido incoado una repercusión económica en contra del demandado. Ha podido darse una verdadeira diffamatio judicialis. Y si los ordenamientos jurídicos conceden para oponerse a la difamación extrajudicial (a la jactancia de hecho o de derecho) medios tan enérgicos como o son las pretensiones de jactancia o las declarativas negativas, es evidente que deben proteger aun más a quien haya sido objeto de tal diffamatio (en público, ante la sociedad) y por medio de una demanda judicial" (Víctor Fairen Guillén, El juicio ordinario y los plenarios rapidos (los defectos en la recepción del derecho procesal común; suscausas y consecuencias en doctrina y legislación actuales), p. 189).

72. Cf. Daniela Barbosa, Submarino e Americanas.com podem ficar 3 dias sem vender em SP, Exame.com, 10 nov. 2011. 
judicial definitivo obtido é restrito aos elementos levados aos autos. É o que ocorre, por exemplo, na ação monitória, em que a cognição é restrita e a decisão judicial somente abrange esses elementos levados aos autos, não ampliando a discussão.

Aqui é importante analisar a eficácia preclusiva da coisa julgada e os seus limites. $\mathrm{O}$ art. 468 do CPC é claro ao asseverar que a coisa julgada "tem força de lei nos limites da lide e das questões decididas", 73 enquanto o art. 469 aduz que somente forma a coisa julgada a parte dispositiva da sentença e não os seus motivos. ${ }^{74}$ Isso nos leva a uma conclusão importantíssima para a análise do princípio da igualdade sob a óptica das tutelas diferenciadas. A coisa julgada fica limitada ao somente o objeto do processo, em sentido estrito, não ampliando-se a discussão para outros pontos que não sejam exclusivamente o objeto do processo. ${ }^{75}$ É incorreto, portanto, afirmar que a coisa julgada se estende a todas as questões debatidas e mesmo não decididas no processo.

Essa limitação da coisa julgada somente ao objeto do processo, não abrangendo motivação e outras questões subsidiárias levadas no processo, é uma garantia para o réu, uma vez que ele terá garantido que apenas aquilo de que exatamente ele se defendeu e as razões daquela ação transitarão em julgado. O que lhe dá a oportunidade de, futuramente, seja a hipótese, ajuizar uma ação específica contra o mesmo autor, mas abrangendo outro objeto do processo.

Aqui se opera a dita eficácia preclusiva da coisa julgada, que nada mais é que o "impedimento à rediscussão do que foi (ou do que poderia ter sido) discutido na fase cognitiva". ${ }^{76}$ Essa preclusão do processo (a mais forte delas, inclusive) é uma garantia

73. "Art. 468. A sentença, que julgar total ou parcialmente a lide, tem força de lei nos limites da lide e das questões decididas".

74. Botelho de Mesquita comenta sobre os limites da coisa julgada: "Voltando agora ao disposto no art. 469 do CPC podemos verificar que, para definir o que faz coisa julgada, serviu-se o legislador processual de uma fórmula negativa: disse o que não faz coisa julgada; definiu por exclusão. Ora excluídos os elementos expressamente indicados nos incisos desse artigo, segue-se a conclusão de que, transitada a sentença em julgado, tornar-se-ão imutáveis e indiscutíveis os elementos restantes, a saber: o elemento declaratório, a que já nos referimos, a manifestação de vontade (sentenças de procedência) e o juízo de rejeição do pedido (sentenças de improcedência" (José Ignácio Botelho de Mesquita, A coisa julgada, p. 6-7).

75. "[...] não se abrangem na coisa julgada ainda que discutidas e decididas, as questões que, sem constituir objeto do processo em sentido estrito, o juiz deverá examinar, como premissa da questão principal (questões prejudiciais em sentido estrito): foram elas conhecidas, mas não decididas, porque sobre elas o juiz não sentenciou, e por isso podem ser julgadas livremente em outro processo, mas para fim diverso do objetivado no processo anterior; e o resultado desse processo deve permanecer intangível, mas para qualquer outro efeito subsistem intactas as questões prejudiciais" (Enrico Tullio Liebman, Eficácia e autoridade da sentença e outros escritos sobre a coisa julgada, p. 56).

76. Ada Pellegrini Grinover, Considerações sobre os limites objetivos e a eficácia preclusiva da coisa julgada, Revista Síntese de Direito Civil e Processual Civil, ano III, n. 16, p. 29. 
para o réu de que a questão não será eternamente rediscutida e levada ao Poder Judiciário.

\subsection{Princípio do devido processo legal}

Tendo asseverado que uma das principais características da tutela diferenciada é a sumarização da cognição, tratemos da estabilização da tutela sob a óptica dos princípios processuais. A questão principal que se coloca é: qual o limite da sumarização da cognição?

Um dos princípios processuais fundamentais é o devido processo legal que garante condições mínimas para o desenvolvimento regular do processo, proporcionando igualdade de defesa entre as partes. Somente observando o princípio do devido processo legal que este, como instrumento, pode atingir sua finalidade. ${ }^{77}$

$\mathrm{O}$ due process of law é de origem estadunidense e foi introduzido na Constituição norte-americana pela $5^{a}$ Emenda ${ }^{78}$ passando a guiá-la por completo. No Brasil, mesmo levando em consideração as diferenças entre as duas cartas constitucionais, além do devido processo legal, há diversos outros princípios que guardam os direitos dos cidadãos. Por outro lado, nos Estados Unidos da América, a Constituição, muito mais enxuta que a brasileira, não possui um rol exemplificativo e, portanto, o princípio do due process of law é muito mais utilizado, tanto formalmente quanto subjetivamente, como forma de garantir a aplicação da Constituição. Assim, além das garantias formais e intrínsecas do devido processo legal, nos Estados Unidos ele também é utilizado como norma ética, do dever de guardar a boa-fé durante o processo etc.

77. "A doutrina salienta que o procedimento, com a garantia do devido processo legal, tem o condão de legitimar o exercício da função jurisdicional" (Rogério Aguiar Munhoz Soares, Tutela jurisdicional diferenciada, p. 38).

78. "No person shall be held to answer for a capital, or otherwise infamous crime, unless on a presentment or indictment of a Grand Jury, except in cases arising in the land or naval forces, or in the Militia, when in actual service in time of War or public danger; nor shall any person be subject for the same offense to be twice put in jeopardy of life or limb; nor shall be compelled in any criminal case to be a witness against himself, nor be deprived of life, liberty, or property, without due process of law; nor shall private property be taken for public use, without just compensation". Pode-se considerar que o due process of law teve origem na Carta Magna de João Sem-Terra, em 1.215, quando os nobres se revoltaram com atos praticados pelo rei e exigiram uma limitação à sua prática. 
No Brasil, ${ }^{79}$ por nossa Constituição possuir um rol mais exemplificativo e prever outros princípios, o devido processo legal atuaria mais como garantidor do contraditório e da ampla defesa, o que poderia ser considerado mais formal. Ao garantir princípios dos mais importantes em nosso sistema jurídico, pode-se afirmar que ele é a origem dos demais princípios processuais-constitucionais.

De igual forma, o devido processo legal, além da sua função geradora e mesmo integradora, tem a função de preencher lacunas, porque na ausência de algum princípio (ou em sua inexistência) deve ser aplicado o devido processo legal. Assim, Ada Pellegrini Grinover ${ }^{80}$ assevera que o processo tem de dar oportunidade às partes de produzirem provas, oferecerem respostas e debaterem, sendo somente após tudo isso prestada uma verdadeira tutela jurisdicional. Para Cândido Rangel Dinamarco: “O traçado do procedimento, como conjunto de atos ordenados, é por isso um dos aspectos do devido processo legal em sua projeção sobre o sistema do processo civil". ${ }^{81}$

Desse importante princípio decorrem os demais - como o contraditório, a ampla defesa, o juiz natural, o dever de motivação, a igualdade entre as partes -, pois apenas garantindo que a função jurisdicional seja plenamente garantida por oportunidades iguais às partes os demais princípios processuais constitucionais encontram campo fértil para se desenvolver. Contudo, é importante ponderar que respeito ao devido processo legal não significa, necessariamente, um processo longo e demorado, passando por todas as fases do procedimento ordinário. Pode muito bem existir a sumarização do procedimento sem que haja um desrespeito ao devido processo legal. O que se deve garantir, sempre, é a plena participação das partes, sem que um processo seja permeado por inúmeros despachos de "manifeste-se a outra parte", 82 mas em que o juiz tenha um papel ativo e realmente decida a questão posta no momento adequado, depois de realizado o contraditório e deixado claro às partes que o feito merece ser

\footnotetext{
79. "LIV - ninguém será privado da liberdade ou de seus bens sem o devido processo legal".

80. Cf. Ada Pellegrini Grinover, O processo em sua unidade, vol. 2.

81. Cândido Rangel Dinamarco, Instituições de direito processual civil, vol. 2, p. 30.

82. Marcelo Bonício trata exatamente desse assunto, ao afirmar que, "normalmente, a postura do juiz que exige um grau muito elevado de certeza para julgar esconde uma tendência burocrática e comodista que deve ser evitada a todo custo. Devem prevalecer, no espírito do juiz, a relavitização do ônus da prova e a redução de seu peso, ou seja, que o 'juiz aja como a pessoa comum ao formar sua convicção, concluindo pela existência do fato quando a sua consciência tiver por bem mais provável a existência do que a inexistência', sem chegar a extremos de exigência" (Marcelo José Magalhães Bonício, Proporcionalidade e processo: a garantia constitucional da proporcionalidade, a legitimação do processo civil e o controle das decisões judiciais, p. 83).
} 
julgado naquele momento, antecipadamente, pois não é o caso de produção de outras provas. $^{83}$

\subsection{Princípio do contraditório e da ampla defesa}

O contraditório e a ampla defesa são duas características básicas do processo que estão intrinsecamente ligadas ao processo legal acima tratado, sendo essenciais para o desenvolvimento do processo justo. A questão é: como conciliar o contraditório com a estabilização da tutela diferenciada que não é uma sentença? ${ }^{84}$

Muito se discute a respeito da diferenciação entre contraditório e ampla defesa. Alguns autores negam que exista essa diferença entre os dois princípios, euquanto, entre os que a afirmam, não há uma linha que separe claramente um do outro.

Sica, citando Rogério Lauria Tucci e José Rogério Cruz e Tucci, define que o direito à ampla defesa seria resumido da seguinte forma:

[...] a concepção moderna do denominado rechtliches Gehör, isto é, da garantia de ampla defesa, seja qual for a natureza do objeto do processo, compreende: 1) o direito de ser informado; 2) bilateralidade da audiência (contrariedade); 3) o direito à prova legitimamente obtida ou produzida. ${ }^{85}$

Nelson Nery Júnior ${ }^{86}$ e Marinoni defendem que o direito de ação e a ampla defesa são princípios que derivam diretamente do contraditório, uma vez que ele é garantia tanto para o réu quanto para o autor. Conforme José Roberto dos Santos Bedaque:

83. Luiz Fux assim assevera: "Destarte, o devido processo legal está encartado no direito ao processo como direito ao meio de prestação da jurisdição, que varia conforme a natureza da tutela de que se necessita. O direito à jurisdição não é senão o de obter uma justiça efetiva e adequada" (Luiz Fux, Tutela de segurança e tutela de evidência (fundamentos da tutela antecipada), p. 319).

84. Andrea Graziosi aponta ainda a seguinte questão: “[...] un processo sommario è, direito quasi ontologicamente, un processo nel quale il giudice non ha la possibilità di avere una conoscenza approfondita e completa del caso sottopostogli, e le parti, dal canto loro, non sono messe in condizione di esercitare a pieno i loro diritti difensivi” (Andrea Graziosi, La cognizione sommmaria del giudice civile nella prospettiva delle garanzie costituzionali, Rivista Trimestrale di Diritto e Procedura Civile, vol. 63, n. 1, p. 163-174). Para o autor, o simples fato de ser um processo de cognição sumária já restringe às partes a possibilidade de defesa e, consequentemente, o contraditório no processo.

85. Heitor Vitor Mendonça Sica, $O$ direito de defesa no processo civil brasileiro: um estudo sobre a posição do réu, p. 42.

86. Cf. Nelson Nery Júnior, Princípios do processo na constituição federal; Luis Guilherme Marinoni. Técnica processual e tutela dos direitos. 
Contraditório nada mais é do que o conjunto de atividades desenvolvidas pelos sujeitos do processo, reveladoras da existência de diálogo efetivo entre eles, visando à correta formação do provimento jurisdicional. A participação das partes é fundamental para conferir legitimidade à tutela, pois significa que a elas foi assegurado o poder de influir no convencimento do juiz. ${ }^{87}$

Segundo esse entendimento, o contraditório é a participação das partes no processo, mas o autor nada fala sobre o grau dessa participação. Logicamente, há toda uma discussão sobre a profundidade desse contraditório e se ele seria limitado.

Em um processo de cognição plena e exauriente, claramente o contraditório não fica restrito à fase postulatória, não se resume às meras alegações das partes, mas também é essencial quando da realização da fase probatória em que as partes discutem livremente. ${ }^{88}$ Dessa forma, parte da doutrina defende que o contraditório é a plena participação das partes no processo, expondo amplamente as suas razões, apresentando impugnações, participando ativamente da fase probatória para somente após esse exercício intensivo chegar-se à sentença. ${ }^{89}$

No Brasil, não há problemas na limitação da participação das partes no processo, pois temos o sistema do julgamento antecipado da lide, de acordo com o art. 333 do CPC. Na Itália, porém, qualquer limitação no contraditório deve ser considerada inconstitucional, ${ }^{90}$ portanto não se admite a sumarização da cognição, pois o processo somente poderia entregar a tutela jurisdicional após exercido o contraditório, com a

87. José Roberto dos Santos Bedaque, op. cit., p. 94.

88. Ainda, conforme Vittorio Denti (La giustizia civile: lezioni introduttive, p. 104), o contraditório não se limita somente à fase inicial do processo, mas deve ser respeitado durante todo o desenvolvimento do processo para somente então chegar a uma sentença que possa transitar em julgado.

89. Nesse sentido entende Barbosa Moreira, ao escrever sobre o princípio do contraditório sobre a então recente Constituição Federal, que elevou tal princípio ao status constitucional: "L'art. 5, n. $\mathrm{LV}$, de la nouvelle Constitution assure aux plaideurs la garantie du contradictoire et le 'ample défense, avec les moyens et les recours qui lui sont inhérents'. La garantie du contradictoire signifie essentiellemente que le demandeur et le défendeur doivent jouir tous les deux de la possibilité effective de participer au déroulement du procès, d'exposer leurs raisons au juge, d'apporter les preuves de leurs allégations, de présenter leurs observations sur les arguments de l'adversaire et sur les preuves apportées par celui-ci ou ordonées d'office. Elle implique pour le juge l'interdcition de prendre des mesures sans en avertir les parties et d'appuyer ses décisions sur des faits et des résultats de l'instruction au sujet desquels elles n'auraient pu s'exprimer" (José Carlos Barbosa Moreira, Les principes fondamentaux de la procédure civile dans la nouvelle constitution brésilienne, in: , Temas de Direito Processual, p. 42).

90. Cf. Enrico Tullio Liebman, Il principio del contraditorio nel processo civile, in: Centro Nazionale di Prevenzione e Difesa Sociale, La protezione giuridica del lavratore, apud Giuseppe Tarzia, Il contraditorio nel processo esecutivo, Rivista di Diritto Processuale, n. 2, p. 193. 
realização de provas de forma exauriente, com as partes tendo feito todas as alegações. $^{91}$

Como assevera Rodrigo Del Debbio, "nenhum princípio é absoluto", 92 devendo ser lido em consonância com os demais princípios processuais. Para esse autor, todos os princípios têm sua carga ideológica e são concebidos em determinados momentos históricos que privilegiam a sua escolha em detrimento da de outros princípios.

Contudo, a história se modifica e novas escolhas devem ser feitas. Não afirmamos que o contraditório deva ser deixado de lado, mas que seja relativizado com os demais princípios processuais que hoje se mostram mais latentes para atender às necessidades sociais e políticas. Nesse sentido, o contraditório sem limitação, na sua forma clássica, pode impossibilitar a concretude dos demais princípios. Ele deve ser relativizado diante de outros princípios que se mostram mais prementes, principalmente em processos que não demandam uma grande cognição, realização de prova, bem como ações em que não haja uma "oposição séria do demandado à pretensão de quem se vale do processo para tutela e realização de seu direito", ${ }^{93}$ e também em ações que possam causar risco de difícil reparação ou lesão grave, casos em que a demora na concessão da tutela possa frustar a tutela em si.

Por outro lado, deve-se ter em mente que há uma limitação também para essa relativização do contraditório, um núcleo duro que seja mantido e não possa ser modificado, sob pena de se contaminar o instrumento processual.

Em algumas situações, o direito pátrio permite a limitação do contraditório - por exemplo, do processo de execução, sumário e sumaríssimo. Também há situações do contraditório postecipado. Trata-se de situações em que a urgência do direito, especialmente a sua perenidade, não permite que se aguarde a realização do contraditório para apenas então dar a decisão. Nesses casos, concede-se primeiramente a tutela pleiteada para, depois, realizar-se o contraditório. ${ }^{94}$ Em situações assim, a

91. Na doutrina nacional, a sumarização da cognição é amplamente aceita e não é considerada inconstitucional, uma vez que se admite o julgamento antecipado quando se tratar de questão de direito, conforme o art. 333 do CPC, bem como há procedimentos sumários e os dos juizados especiais em que não há produção de prova e a oralidade é privilegiada, de modo que o julgamento ocorra de maneira mais rápida.

92. Cristiano Rodrigo Del Debbio, Tutela jurisdicional diferenciada: técnicas para sumarização da cognição, p. 47.

93. Moacyr Amaral dos Santos, Ações cominatórias no direito brasileiro, tomo I, p. 142.

94. É o caso do procedimento monitório, no qual o devedor é intimado a pagar sem ter participado da decisão que deferiu a expedição do mandado de pagamento. Contudo, é assegurada a sua participação em momento posterior do processo. 
cognição fica limitada pelas alegações e provas trazidas pelo autor, mas também o contraditório não é sacrificado, mas diferido após a análise da tutela.

Isso ocorre muito em casos de antecipação de tutela, em que a premência e a perenidade do direito não podem aguardar a realização do contraditório. Quanto a essa questão, Rodrigo Del Debbio elenca dois tipos de contraditório postecipado: diferido e eventual. No primeiro, o contraditório é exercido após a análise da tutela inicial. No segundo, o contraditório somente é iniciado pelo réu se este demonstrar interesse e em um processo separado.

\begin{abstract}
A inversão do contraditório visa atender ao reclamo de uma prestação jurisdicional mais célere e efetiva. Para proteger determinadas situações - em especial naquelas em que exista risco de dano irreparável para uma das partes - o legislador reputa conveniente sacrificar a certeza e segurança resultantes de uma tutela lastreada em cognição plena e exauriente, e permite a rápida e concreta satisfação do direito mediante uma cognição limitada, baseada na probabilidade de êxito do demandante. $\mathrm{O}$ foco do legislador deixa de ser a certeza e passa a ser os graus de probabilidade por meio dos quais o processo é capaz de produzir os resultados desejados, operando modificações na realidade existente, assumindo riscos calculados, em prol da efetividade. ${ }^{95}$
\end{abstract}

Uma das técnicas utilizadas para a sumarização da cognição é a postergação ou a inversão do contraditório. Luiz Fux defende essa ténica, não a taxando de inconstitucional, porque existiriam situações em que é necessária a urgente análise do Judiciário, prescindindo o contraditório no momento inicial. ${ }^{96,97}$

Ovídio Batista da Silva entende que o denominado contraditório eventual se apresenta de duas formas. A primeira forma é o do contraditório postecipado, que fica a cargo do réu para ser iniciado. A outra modalidade ocorre quando não existe a possibilidade de apresentar contestação, mas será então necessário promover uma ação autônoma para a discussão da questão. É o caso das ações petitórias com relação às ações possessórias. ${ }^{98}$

95. Cristiano Rodrigo Del Debbio, op. cit., p. 53.

96. Luiz Fux, Tutela de segurança e tutela de evidência (fundamentos da tutela antecipada), p. 149.

97. No mesmo sentido, Andrea Graziosi (La cognizione sommmaria del giudice civile nella prospettiva delle garanzie costituzionali, Rivista Trimestrale di Diritto e Procedura Civile, vol. 63, n. 1, p. 163-174) aborda o procedimento monitório italiano. Segundo o autor, o contraditório é realizado somente em momento posterior, mas é dada à parte a possibilidade de instaurar o contraditório. Essa técnica resulta em vários benefícios, pois permite que o contraditório seja apenas instaurado quando a parte realmente entender que seja o caso.

98. Ovídio Araújo Baptista da Silva, O contraditório nas ações sumárias, Revista da Escola Paulista de Magistratura, vol. 2, n. 2. 
Claro que sempre existem afirmações equivocadas que relacionam os processos de cognição sumária com a inexistência de contraditório, como faz o autor italiano Antônio Carrata, ao afirmar que a tutela antecipada tem cognição sumária pois não respeita o contraditório. ${ }^{99}$

Em nenhum momento o contraditório é desrespeitado, como demonstramos, e todos os tipos de tutela de cognição sumária existente no processo civil brasileiro permitem a ampla defesa e o contraditório, ainda que postecipado, em caso de tutela de urgência. Em nenhuma hipótese não é dada a oportunidade ao réu de se manifestar nos autos, de apresentar as suas razões e recorrer. $\mathrm{O}$ fato de não existir um processo de cognição aprofundada, com a produção de provas (haja vista que muitas vezes não é necessária) não significa um desrespeito ao contraditório e à ampla defesa. Pelo contrário, significa que esse princípio constitucional não foi levado a um extremo que pode levar ao ridículo em algumas situações, ${ }^{100}$ mas foi equilibrado com todo o sistema principiológico que existe na nossa Constituição, chegando a um resultado prático para as partes, sem que essas sofressem limitação do contraditório ou qualquer outro tipo de prejuízo.

99. O autor explica outras características da tutela antecipada e dá as razões para ela ser considerada de cognição sumária. Dentre essas explicações todas nos parecem muito corretas, com exceção da passagem em que ele explica em que não é respeitado o contraditório: "Ciò posto, va detto che $\mathrm{i}$ provvedimenti di tutela propriamente anticipatoria interinale sono per natura sommari: e questo o perché, come nel caso dei provvedimenti a struttura monitoria, sono pronunciati a conclusione di una fase o di un sub-procedimento sommario, in quanto non rispettoso del principio del contraddittorio pieno ed anticipato e fondato su una cognizione sommario in quanto superficiale o parziale, o perché, come nel caso delle ordinanze anticipatorie di condanna, sono pronunciati nel corso del processo ordinario o nel corso di processi speciali a cognizione piena sulla base della cognizione sommaria da parte del giudice, il quale si è limitato a formare il suo convincimento sulla probabile pronuncia di una sentenza favorevole al richiedente o in relazione a risultati probatori, ordinari, sì, ma incompleti (perché necessariamente non definitivi) (ad es. artt. 186 bis, 423, 186 quater, 264, 666 et similia) o in base a risultati probatori non ordinari (ad es. art. 186 ter)" (Antonio Carratta, Profili sistematici della tutela anticipatoria). As demais justificativas do autor nos parecem corretas, em especial a de cognição sumária baseada em um juízo superficial e parcial. No entanto, não nos parece correto afirmar que ela sempre viola o contraditório.

100. Em um processo no qual atuei no Juizado Especial Cível, o juiz despachou durante cerca de um ano sempre da seguinte forma: "Diga a parte contrária". As partes simplesmente repetiam os argumentos já expeditos e sempre pediam o julgamento da lide no estado em que se encontrava (afinal, era um processo de juizado especial cível, e não havia grande dificuldade na solução do processo). O excesso do contraditório foi utilizado como uma desculpa pelo juiz, que não queria se posicionar no processo, postura que claramente prejudicou as partes. 


\subsection{Princípio da eficiência e da duração razoável do processo}

Segundo Proto Pisani, o processo deve buscar o fim a qual foi instituído. Não basta que o Estado outorgue tutela jurisdicional a quem tem razão; é necessário também que o dano causado seja recomposto da mesma forma que seria sem a intervenção do Poder Judiciário, como se fosse cumprido de forma espontânea. A intervenção do Estado deve ocorrer necessariamente no momento adequado e ainda garantir a segurança.

A grande motivação para o desenvolvimento deste trabalho foi, sem dúvida, ao longo da observação de como se comporta o Judiciário, verificar que ele não é nem eficiente nem efetivo. O princípio da eficiência está previsto no seu art. 37 de nossa Constituição. ${ }^{101}$ Trata-se de um princípio de direito administrativo que impõe ao Estado o dever de realizar todas as suas atividades de forma eficiente. Obviamente, o Poder Judiciário também está obrigado a seguir esse requisito no desenvolvimento de sua atividade.

Apesar de ter sido incluído na Constituição Federal apenas em 1998, pela Emenda Constitucional n. 19, o princípio da eficiência se baseia em dois outros princípios já tratados, quais sejam, o do amplo acesso à Justiça (art. $5^{\circ}$, inciso XXXV) ${ }^{102}$ e o do devido processo legal (art. $5^{\circ}$, inciso LIV) ${ }^{103}$. Posteriormente, ele deu origem ao princípio da duração razoável do processo, incluído na denominada Reforma do Judiciário, via Emenda Constitucional n. 45, de 2004 (art. 5º inciso LXXVIII) ${ }^{104}$. Desse princípio podem ser extraídos quatro subprincípios. ${ }^{105}$

O primeiro deles é a eficiência como efetividade. A ideia de efetividade está ligada à entrega ao autor do bem da vida ou, caso esse se mostre indevido, à sua negativa. De qualquer forma, a efetividade é a outorga da tutela jurisdicional, a resposta do Estadojuiz ao problema apresentado, com a solução do conflito. A efetividade é o próprio alcance dos escopos do processo. Vale relembrar que a outorga da tutela jurisdicional

101. “Art. 37. A administração pública direta e indireta de qualquer dos Poderes da União, dos Estados, do Distrito Federal e dos Municípios obedecerá aos princípios de legalidade, impessoalidade, moralidade, publicidade e eficiência e, também, ao seguinte".

102. "XXXV - a lei não excluirá da apreciação do Poder Judiciário lesão ou ameaça a direito".

103. "LIV - ninguém será privado da liberdade ou de seus bens sem o devido processo legal".

104. "LXXVIII a todos, no âmbito judicial e administrativo, são assegurados a razoável duração do processo e os meios que garantam a celeridade de sua tramitação".

105. Essa subdivisão dos princípios foi retirada de João Gilberto Gonçalves Filho, O princípio constitucional da eficiência no processo civil. 
não é apenas o proferimento da decisão, mas, a efetiva entrega do bem da vida a quem foi buscar o Judiciário, com a satisfação da decisão.

O segundo subprincípio decorrente da eficiência é o da celeridade. Um dos objetivos do processo é restabelecer a situação injusta a que foi colocada a pessoa que procurou o Judiciário, e isso deve ser feito da forma mais célere possível, evitando que as situações injustas se perpetuem. Contudo, existe um determinado tempo para que o processo se desenvolva, para que as provas sejam realizadas e apresentadas, para que as partes apresentem seus argumentos, exercendo o contraditório, e, por fim, para que o juiz possa exercer a sua cognição. E toda essa atividade judiciária leva um tempo que, muitas vezes, o jurisdicionado não pode aguardar em razão da natureza da tutela que foi buscar no Judiciário.

Nesse âmbito, a tutela diferenciada pode perfeitamente buscar novas soluções para o processo. Não há dúvida de que o processo demora um tempo mínimo para se desenvolver, mas, em determinadas oportunidades, esse tempo pode ser encurtado dependendo da questão levada ao juiz.

Dessa forma, o princípio da celeridade não busca soluções imediatas para as questões postas em juízo, pois se sabe que o processo tem um tempo mínimo de duração e se tolera essa duração mínima do processo, necessária para respeitar os demais princípios processuais. O que não se aceita é a demora inexplicável, por tempos “mortos" no cartório judicial, por ausência de resposta do juiz por acúmulo de trabalho ou mesmo por causa de um juiz que queira enfatizar tanto o contraditório que acaba não decidindo a questão. ${ }^{106}$

Trataremos da segurança jurídica como outro subprincípio da eficiência. Eis uma das grandes problemáticas: como encontrar um ponto de equilíbrio entre uma decisão que foi meramente estabilizada, de cognição sumária, e ao mesmo tempo trazer segurança jurídica? A segurança jurídica possui dois aspectos: o primeiro é obter uma resposta do Poder Judiciário sem ter de esperar durante anos para isso; o segundo é a previsbilidade das decisões judiciais - não dá para entrar no Judiciário sem aguardar o que ele irá decidir, contando com a chamada justiça lotérica, situação de muita injustiça e que não deve ser perpetuada. O resultado deve ser previsível conforme o desenvolvimento do processo, não podendo surpreender as partes.

106. É exemplo aquele juiz que não decide nunca, que sempre determina que as partes se manifestem sobre tudo: é um contraditório infinito, não são respeitadas as preclusões processuais, o que faz com que o processo não percorra seu caminho natural. 
Por fim, o outro subprincípio da eficiência é a economia processual. E economia processual aqui diz respeito à regra das nulidades processuais. Ou seja, somente se proclama a nulidade caso ela tenha resultado em prejuízo. Se não ocorreu qualquer prejuízo para as partes, o ato é aproveitado.

A economia processual far-se-á sentir, principalmente, quando da total informatização do processo. Essa revolução tecnológica já está sendo sentida nos processos digitais que já existem. Um juiz demora cerca de três meses para julgar um processo antecipadamente, porque foram suprimidos todos os tempos mortos, como a juntada de documentos, expedição de carta de citação, não localização dos autos pela serventia etc. Enfim, grande parte dos problemas burocráticos foram suprimidos nos processos digitais. ${ }^{107}$

Podemos afirmar que fica a critério das partes e do juiz escolher qual princípio deve prevalecer nesse tipo procedimental, ao mesmo tempo que fica a critério das partes abrir mão de um contraditório mais longo e demorado, e garantir uma cognição plena ou a escolha da efetividade do processo, com a outorga de uma tutela jurisdicional rápida. ${ }^{108}$

A duração razoável do processo, no sistema brasileiro elevada a princípio constitucional, é um importante fator que deve ser levado em consideração. A demora na entrega da tutela jurisdicional não é um problema exclusivamente europeu, mas na União Europeia foram estabelecidas regras de duração mínima do processo, determinando que as pessoas têm direito a um julgamento em um prazo razoável, como dispõe o art. $6^{\circ}$ da Convenção Europeia para Salvaguarda dos Direitos do Homem e das Liberdades Fundamentais. ${ }^{109}$

107. Ainda existem algumas dificuldades que são decorrentes da falta de familiaridade com o novo recurso por parte dos juízes, funcionários públicos e mesmo advogados. No entanto, acreditamos que esse problema será solucionado com o passar do tempo.

108. "Semplificando, potremmo dire che le parti possono rinunciare al giudicato, e al rigido rispetto di tutte le garanzie difensive che ad esse sempre si deve accompagnare, per ottenere in cambio una maggior speditezza procedimentale" (Andrea Graziosi, La cognizione sommaria del giudice civile nella prospettiva delle garanzie costituzionali, Rivista Trimestrale di Diritto e Procedura Civile, vol. 63, n. 1, p. 163-174.

109. “1. Qualquer pessoa tem direito a que a sua causa seja examinada, equitativa e publicamente, num prazo razoável por um tribunal independente e imparcial, estabelecido pela lei, o qual decidirá, quer sobre a determinação dos seus direitos e obrigações de caráter civil, quer sobre o fundamento de qualquer acusação em matéria penal dirigida contra ela. O julgamento deve ser público, mas o acesso à sala de audiências pode ser proibido à imprensa ou ao público durante a totalidade ou parte do processo, quando a bem da moralidade, da ordem pública ou da segurança nacional numa sociedade democrática, quando os interesses de menores ou a proteção da vida privada das partes no processo o exigirem, ou, na medida julgada estritamente necessária pelo tribunal, quando, em circunstâncias especiais, a publicidade pudesse ser prejudicial para os interesses da justiça". 
Também determinam que o processo deve ter uma duração razoável o art. 111 da Constituição italiana, ${ }^{110} \mathrm{o}$ art. 24.2 Constituição espanhola ${ }^{111}$ e a regra expressa na $6^{\mathrm{a}}$ Emenda à Constituição norte-americana; de forma mais firme e explícita é a determinação dos arts. 26 e 257 da Constituição da Venezuela. ${ }^{112}$ Isso porque, reiteramos, garantir o acesso ao Judiciário não é outorgar a tutela jurisdicional, pelo contrário: a outorga da tutela jurisdicional (e, consequentemente, sua própria essência) deve ser feita de forma eficiente, respeitando todos os princípios processuaisconstitucionais, mas em tempo hábil.

Como no Brasil, na Itália' ${ }^{113}$ também foi imposto pelo legislador (ordinário, no caso) o princípio da razoável duração do processo, mas a simples inserção de um princípio não significa que o sistema irá mudar. É necessária uma mudança de mentalidade, de estrutura e do próprio processo. ${ }^{114}$

110. "Ogni processo si svolge nel contraddittorio tra le parti, in condizioni di parità, davanti a giudice terzo e imparziale. La legge ne assicura la ragionevole durata".

111. "Todas las personas tienen derecho a obtener la tutela efectiva de los jueces y tribunales en el ejercicio de sus derechos e intereses legítimos, sin que, en ningún caso, pueda producirse indefensión. 2. Asimismo, todos tienen derecho al Juez ordinario predeterminado por la ley, a la defensa y a la asistencia de letrado, a ser informados de la acusación formulada contra ellos, a un proceso público sin dilaciones indebidas y con todas las garantías, a utilizar los medios de prueba pertinentes para su defensa, a no declarar contra sí mismos, a non confesarse culpables y la presunción de inocencia".

112. "Art. 26. Toda persona tiene derecho de acceso a los órganos de administración de justicia para hacer valer sus derechos e intereses, incluso los colectivos o difusos, a la tutela efectiva de los mismos y a obtener con prontitud la decisión correspondiente. El Estado garantizará una justicia gratuita, accesible, imparcial, idónea, transparente, autónoma, independiente, responsable, equitativa y expedita, sin dilaciones indebidas, sin formalismos o reposiciones inútiles. [...] Art. 257. El proceso constituye un instrumento fundamental para la realización de la justicia. Las leyes procesales establecerán la simplificación, uniformidad y eficacia de los trámites y adoptarán un procedimiento breve, oral y público. No se sacrificará la justicia por la omisión de formalidades no esenciales".

113 Na Itália, um país mais garantista que o Brasil, a introdução da duração razoável do processo levou a intensos debates dos processualistas italianos, que se questionavam como o processo poderia ser justo e ter uma duração razoável: "Se dunque è la legge che deve contestualmente disciplinare il processo giusto ed assicurare la sua ragionevole durante in quali direzioni dovrà muoversi il legislatore ordinario? Come rileva e come opera il principio di legalità nel processo? Quale il suo ruolo specifico, in rapporto con le altre garanzie fondamentali del processo giusto?" (Antonio Carrata, Strutura e funzione nei procedimenti giurisdizionali sommari, in: (org.), La tutela sommaria in Europa: studi).

114. Andrea Graziosi afirma que não basta apenas constitucionalizar o princípio da duração razoável do processo, essa constitucionalização não fará milagres. Por outro lado aponta que a escolha por processos mais céleres e que dispensam a cognição plena já representam um avanço na mentalidade italiana. "A questo scopo bisogna anzitutto tentare di attribuire un contenuto tecnicamente più definito al dovere imposto al legislatore ordinario dall'art. 111 , comma $2^{\circ}$, cost. A me pare che se si considera il problema in termini di pura tecnica processuale, l'aver inserito nella Costituzione l'obbligo di assicurare per legge una durata ragionevole ai processi equivale ad aver costituzionalizzato il principio di economia processuale, ossia la regola che impone di prediligere tra più opzioni possibili (normative ma anche esegetiche) per conseguire un certo risultato quella che consente l'uso più razionale ed economico delle risorse giudiziarie a 
No caso brasileiro há autores céticos que entendem que essa inclusão na Constituição em nada afetará o problema da morosidade do Judiciário. ${ }^{115}$ Por outro lado, há autores que entendem que, apesar de a mudança constitucional já decorrer do próprio princípio do devido processo legal, ela deve ser enxergada com bons olhos, uma vez que foi expressamente reconhecido e isso traz consequências importantes ao mostrar de forma clara aos operadores do direito que o princípio está ali e deve ser seguido. Desse modo, segundo João Gilberto Gonçalves Filho, a simples inserção do princípio dá início a uma série de debates doutrinários e jurisprudenciais sobre a questão ${ }^{116}$ e isso é extremamente importante, pois os operadores do direito sabem que tal artigo é de aplicação imediata.

Ainda, é importante ressaltar o efeito psicológico que causa o fato de ter sido incluído na Constituição. O efeito é imediato. Os aplicadores do direito sabem da importância e da necessidade de se aplicar referido dispositivo. Durante a Reforma do Judiciário, através da Emenda Constitucional n. 45 foi criado o Conselho Nacional de

disposizione. È evidente che tempi ragionevoli ai processi non potrano mais essere garantiti se i mezzi umani, finanziari ed organizzativi di cui si dispone sono insufficiente, ma è altrettanto evidente che, dal punto di vista della disciplina processualistica, la riduzione della durata dei processo nel loro insieme la si ottiene attraverso norme tese ad ottimizzare l'impiego delle risorse disponibili, ovvero, più in concreto, volte ad evitare inutili sprechi di attività processuale" (Andrea Graziosi, La cognizione sommaria del giudice civile nella prospettiva delle garanzie costituzionali, Rivista Trimestrale di Diritto e Procedura Civile, vol. 63, n. 1, p. 163-174).

115. João Batista Lopes afirmar que "a Emenda n. 45 não implicará modificação no quadro atual de lentidão da Justiça e, portanto, não garantirá a prometida efetividade da jurisdição". Reforma do Judiciário e efetividade do processo civil. Reforma do Judiciário: primeiras reflexões sobre a Emenda Constitucional 45/2004. Teresa Arruda Alvim Wambier et alii, coord. São Paulo, Revista dos Tribunais, 2005. No mesmo sentido é o entendimento de Flávio Luiz Yarshell: "É ilusão imaginar que a eventual aprovação da proposta de Emenda à Constituição da República n. 96 - E, que introduz modificações na estrutura do Poder Judiciário, resolverá o grave, crônico e perverso problema da morosidade desse último; o que nem mesmo poderá ser afastado pela proclamação, constante do inciso LXXVIII do artigo $5^{\circ}$, de que 'a todos, no âmbito judicial e administrativo, são assegurados a razoável duração do processo e os meios que garantam a celeridade de sua tramitação.' É ingenuidade ou desconhecimento supor que um problema de tal complexidade possa ser resolvido como uma pena do legislador que, por melhor técnica que tivesse (nem sempre tem), não seria capaz de, mantidas as condições estruturais do sistema, alterar a realidade das coisas por "decreto" (João Batista Lopes, A reforma do judiciário e a promessa de "duração razoável do processo", Revista do Advogado, ano 26, n. 87).

116. Cf. João Gilberto Gonçalves Filho, O princípio constitucional da eficiência no processo civil. É semelhante o entendimento de José Rogério Cruz e Tucci ao comentar a inclusão de referido princípio em diplomas estrangeiros: "Constata-se que tal previsão não teve como finalidade servir simplesmente 'de fachada' ou 'de bandeira', para jazer como letra morta dos respectivos diplomas que a consagraram... Na verdade o controle jurisdicional de sua observância tem sido, ao longo do tempo, constante e rigoroso. Basicamente, é a partir da interpretação segura das 'dilações indevidas' que se exerce essa fiscalização, considerando-se: a) a complexidade do assunto; b) o comportamento dos litigantes e de seus procuradores, ou da acusação e da defesa no processo penal; c) a atuação do órgão jurisdicional" (José Rogério Cruz e Tucci. Tempo e processo, p. 139). 
Justiça, cuja função é fiscalizar o Poder Judiciário. E mais: dentre as diversas metas criadas por esse órgão, uma ficou especialmente conhecida, pois seu objetivo era julgar todos os processos ainda pendentes desde 2005, entregando a tutela jurisdicional aos cidadãos e garantindo a aplicabilidade da duração razoável do processo. ${ }^{117}$ Essa meta do Conselho Nacional de Justiça trouxe inúmeros benefícios, mas também alguns problemas, já que algumas vezes juízes se viram a julgar rapidamente o processo apenas para cumprir a meta, sem entregar a tutela com qualidade.

Com certeza, a existência de procedimentos especiais que dão a possibilidade de problemas e questões diferentes serem tratadas de forma diversos, não se submetendo a um procedimento ordinário, já progride no sentido da duração razoável do processo e ajuda a fortalecer esse princípio. O fator tempo sempre esteve favorável para quem não tinha razão, desfavorecendo, principalmente, aquele que foi buscar a tutela perante o Judiciário (não estamos falando em processo de autor, mas, geralmente, é o autor que busca uma resposta no Judiciário, e a demora no processo o prejudica). Um processo de cognição plena, portanto, em algumas situações pode se verificar como uma fonte de dano ao autor que tem razão. ${ }^{118}$

Contudo, o princípio da eficiência e da duração razoável do processo não podem ser levados ao extremo. Devem ser respeitadas as garantias mínimas processuais e principalmente o devido processo legal, o contraditório e a ampla defesa. ${ }^{119}$ Celeridade e segurança jurídica não são valores contrapostos, mas, pelo contrário, quanto mais rápido for outorgada a tutela jurisdicional, mais rápido as partes se satisfazem, levando à segurança jurídica. ${ }^{120}$

117. "Identificar os processos judiciais mais antigos e adotar medidas concretas para o julgamento de todos os distribuídos até $31 \mathrm{dez} .2005$ (em $1^{\circ}, 2^{\circ}$ grau ou tribunais superiores)".

118. Andrea Graziosi, La cognizione sommmaria del giudice civile nella prospettiva delle garanzie costituzionali, Rivista Trimestrale di Diritto e Procedura Civile, vol. 63, n. 1, p. 163-174.

119. 'Peraltro, con riferimento alla correlazione fra 'durata' del processo e salvaguardia delle garanzie del 'giusto processo' sempre la Corte costituzionale ha evidenziato che la durata del processo per essere ragionevole, così come impone il $2^{\circ}$ comma dell'art. 111 Cost., deve conciliarsi anche con le altre tutele costituzionali e con il diritto delle parti di agire e difendersi in giudizio garantito dall'art. 24 Cost. Vale a dire che tale principio 'deve essere letto alla luce dello stesso richiamo al connotato di ragionevolezza, che compare nella formulazione normativa, in correlazione con le altre garanzie previste dalla Costituzione, a cominciare da quella relativa al diritto di difesa"” (Antonio Carrata, op. cit.).

120. "É preciso desmistificar a ideia de que segurança e celeridade são valores incompatíveis entre si, de modo que, quanto mais se aumenta a celeridade, perde-se o correspondente em segurança e vice-versa. Isto não está correto. Se pensarmos na segurança em termos de estabilidade da decisão e resolução definitiva do litígio, quanto mais rápida for proferida uma decisão, mais rápida estará estabilizada a decisão e resolvida pela vontade estatal aquela situação da vida, permitindo às partes e à sociedade, esta última pelos terceiros interessados em caráter jurídico ou não, assimilar a vitória 
Ainda há quem argumente que quanto mais célere um processo é, mais prejudicada estaria a qualidade das decisões e, então, isso resultaria em um sacrifício da segurança jurídica. Com todo o respeito, celeridade e segurança jurídica não são opostas nem são conceitos contraditórios. O fato de um processo ficar anos na conclusão não garanta que o juiz decidirá da melhor forma possível, analisando todas as questões e fazendo da sua sentença um tratado de direito civil. Pode significar exatamente o contrário - o processo ficou anos perdido e foi passando na mão de vários juízes sem que nada fosse decidido.

Não necessariamente a celeridade irá prejudicar o processo e afetar a segurança jurídica, porque a celeridade não pode ser concebida sem os demais princípios processuais. Se foi respeitado o contraditório, a ampla defesa, ou seja, o devido processo legal, não há o que sustente essa comparação entre celeridade e segurança jurídica. Logicamente não se prega a celeridade e a duração razoável do processo em detrimento das demais garantias constitucionais, apenas se busca um equilíbrio entre essas garantias e princípios.

Dessa forma, é preciso ter em mente alguns critérios já fixados pela doutrina para falar o que seria uma duração razoável do processo: complexidade do assunto; comportamentodas partes; atuação do Poder Judiciário. ${ }^{121}$ É necessário investigar cada um desses aspectos e verificar se houve abuso das partes, se a matéria é realmente muito complexa ou se somente foi má administração do Poder Judiciário. A garantia da duração razoável do processo deve atuar ao lado das demais garantias constitucionais, não podendo ser considerada desarrazoada se serve para salvaguardar o direito de ação e a defesa das partes, o respeito à garantia do juiz natural e do contraditório. $^{122}$

ou a derrota no seu patrimônio e nas suas perspectivas de futuro" (João Gilberto Gonçalves Filho, op. cit.).

121. Marcelo José Magalhães Bonício, op. cit., p. 59.

122. "Prima di concludere su questo punto occorre un'ultima precisazione. La norma costituzionale richiede che la durata del processo sai ragionevole, non breve. Per comprenderne l'esatto significato diviene allora indispensabile chiarire a cosa faccia riferimento, in questo caso, la Cost. richiamando il requisito della ragionevolezza, poiché si tratta di un concetto di grande rilievo nel campo del diritto costituzionale, ma di per sé non univoco. Nel caso di specie credo che ragionevole significhi, primariamente, compatibile con le altre garanzie costituzionali previste dallo stesso art. 111 e dagli artt. 24 e 25 cost. La durata di un processo non può pertanto considerarsi irragionevole se le sue scansioni temporali sono dettate dalla necessita di salvaguardare il diritto di azione e di difesa delle parti, o il rispetto delle garanzie del giudice naturale, del contraddittorio e della terzietà e imarzialità dell'organo giudicante" (Andrea Graziosi, La cognizione sommaria del giudice civile nella prospettiva delle garanzie costituzionali, Rivista Trimestrale di Diritto e Procedura Civile, ano LXIII, n. 1, p. 137-174). 


\subsection{Conclusão}

Da análise dos capítulos anteriores podemos concluir que é perfeitamente possível obter uma tutela diferenciada respeitando os princípios processuais. Há um claro conflito entre os princípios que deve ser equilibrado. De um lado, temos os princípios da igualdade e da ampla defesa; de outro, princípios da efetividade e da razoável duração do processo. Para obter o tão buscado equilíbrio é imprescindível que um dos princípios seja mitigado em favor de outro: é impossível que todos convivam de forma ampla. Obviamente, o mundo ideal seria o do procedimento de conhecimento, com a possibilidade de ampla defesa para as partes e a ampla instrução probatória. No entanto, essa não é a realidade.

O procedimento ordinário não se compatibiliza com as necessidades da sociedade atual em dar uma resposta rápida e eficaz às questões apresentadas. Não basta proporcionar o acesso ao Judiciário: é necessário outorgar a tutela jurisdicional no tempo adequado - não após anos e anos de tramitação de processo, chegando a situações em que até os autores já faleceram. ${ }^{123}$

Como atualmente o que se procura do Poder Judiciário é uma resposta rápida e efetiva às partes, o princípio do contraditório e da ampla defesa (e em alguma medida o da igualdade) é mitigado para conferir maior efetividade às decisões judiciais. Como exposto, essa mitigação não significa a completa extinção desses princípios do nosso sistema processual, somente um equilíbrio entre eles.

Dessa forma, a efetividade das decisões judiciais não necessarimente anda de mãos dadas com o princípio da igualdade ou com o da uniformidade de tratamento entre as partes. A efetividade autoriza a criação de instrumentos processuais típicos para melhor tutelar o interesse das partes, e nesses instrumentos processuais estão garantidos os direitos dos réus. Essa diferenciação de procedimentos e a consequente

123. Isso, infelizmente, acontece com certa frequência, sobretudo antes da promulgação do Estatuto do Idoso, que dá preferência aos processos cujas partes tenham mais de sessenta anos. Um exemplo pessoal: atuo como advogada em um processo que cobra as complementações previdenciárias dos aposentados da antiga Rede Ferroviária Federal S. A., que foi ajuizado em 1978 e, apesar de a ação ter sido julgada procedente (em 1997), até hoje os aposentados não conseguiram o dinheiro, em razão de diversos recursos protelatórios apresentados pela União e pelo INSS. Como já eram aposentados em 1978, muitos dos autores já faleceram, restando para seus filhos, netos e em alguns casos bisnetos a execução dessa sentença. 
mitigação de alguns princípios na realidade asseguram ainda mais os direitos dos réus e tutelam o interesse do autor. Apenas com essa diferenciação respeitam-se os direitos dos réus. ${ }^{124}$

Justifica-se assim o estudo da tutela diferenciada, de sua natureza, a pesquisa de seus limites e de como ela se compatibiliza com os princípios constitucionais processuais. Partir do pressuposto de que é apenas uma tutela de cognição sumária e, por isso, menos importante (pois não seria aplicada aos grandes casos) equivale a excluir toda uma parcela do direito processual que tutela causas menores ou somente questões de direito.

$\mathrm{Na}$ realidade, vemos que a mitigação do princípio da igualdade nem ocorre. É criado um procedimento diferenciado, no qual está a mitigação, já que as partes não se submeterão ao processo de cognição plena e exauriente. Contudo, em momento algum deve ocorrer a diferenciação no tratamento entre as partes. Não é um processo do autor, o réu não pode ser tratado de forma diferente e lhe é dada a possibilidade de defesa (que será mitigada ou realizada em momento posterior).

Isso porque o processo justo não necessariamente significa um processo com ampla produção probatória que, no entanto, outorga a tutela jurisdicional apenas após muitos anos. Um processo justo é aquele que obedece as normas processuais e respeita, ainda que minimamente, os princípios constitucionais processuais: as partes são tratadas de forma igual e é garantido o devido o processo legal. ${ }^{125}$

124. 'Peraltro, come è facile constatare, 'effettività' non significa, né implica, necessariamente e sempre, 'uniformità (o formale 'eguaglianza') di trattamento. Al contrario, la sua istituzionale vocazione a porsi quale 'denominatore comune' di più garanzie di giustizia la rende pienamente compatibile con la 'diversità' (e, quindi, pure con la 'difformità' o con la 'disuguaglianza') ontologica delle situazioni giuridiche da disciplinare - nonché con la 'differenziazione' di quelle forme di tutela - identificandola, proprio in tali casi, come l'unico vero elemento di 'eguaglianza' (o, se si preferisce, di 'parificazione' e di 'unificazione' garantistica), nel rispetto del 'nucleo essenziale' dei diversi diritti inviolabili, che attengono al rocesso ed alla giurisdizione" (Luigi Paolo Comoglio, Tutela differenziatta e pari effettività nella giustizia civile, Rivista di Diritto Processuale, ano LXIII (seconda serie), n. 6).

125. 'Ora, il diritto al 'giusto processo' nel quale, come si è già accennato, confluiscono (entro il contesto generale dei diritti inviolabili dell'uomo, in base all'art. 2. Cost). il 'diritto al processo' o il 'diritto alla tutela giurisdizionale', le garanzie fondamentali dell'azione e dell'accesso alle corti di giustizia, nonché quelle della difesa e del contraddittorio - non può essere disgiunto dalla sottesa esigenza di effettività delle forme di tutela ottenibili in qualsiasi giudizio avanti ad un'autorità giurisdizionale, il che giustifica l'adozione legislativa di forme diversificate di tutela e di corrispondenti riti differenziati, purché le loro caratteristiche siano sempre tali, da porsi in proporzionale (e, quindi, ragionevole) rapporto con le esigenze diversificate di tutela delle variabili situazioni soggettive da tutelare" (Luigi Paolo Comoglio, Tutela differenziatta e pari effettività nella giustizia civile, Rivista di Diritto Processuale, ano LXIII (seconda serie), n. 6, p. 1529). 


\section{ESTABILIZAÇÃO DA TUTELA DIFERENCIADA E PRAGMÁTICA PROCESSUAL}

\subsection{Coisa julgada}

Uma das grandes questões que surgem da tutela diferenciada é a instabilidade do provimento. Primeiramente, pode soar estranho falar em instabilidade em uma dissertação que trata justamente da estabilidade da tutela. Ocorre que, antes da própria estabilidade, há um momento de instabilidade que as partes têm de suportar, uma vez que, para grande parte da doutrina, a estabilidade do provimento vem somente com a cognição exauriente. ${ }^{1}$

Assim, há entendimento na doutrina brasileira de que a formação da coisa julgada está intrinsecamente ligada à realização de uma cognição aprofundada - o que não ocorreria na tutela diferenciada pois é sua característica fundamental a limitação da cognição. Ainda, a coisa julgada somente poderia ser outorgada para sentenças definitivas, aquelas decisões que versam sobre a questão priancipal, mas que também encerram o processo.

Essa instabilidade decorreria da análise célere e não exauriente do juiz e, por essa razão, o juízo sumário seria instável. Alguns autores afirmam que o juízo sumário poderia ser substituído por um de cognição exauriente e, por essa razão, a principal característica seria a provisoriedade da tutela. ${ }^{2}$ A tutela seria tão provisória que, de acordo com José Carlos Barbosa Moreira, se a parte tiver interesse, não poderia ser negado a ela o direito de uma investigação completa dos fatos, ${ }^{3}$ instaurando-se um procedimento ordinário posterior. Seguindo esse pensamento, não se poderia falar em formação de coisa julgada nessas hipóteses, já que ela somente é admitida em situações em que haja a cognição plena e exauriente.

1. Para Flávio Luiz Yarshell (Tutela jurisdicional), quanto maior o grau de definição, maior será a tutela prestada para a parte. Compartilha desse entendimento Kazuo Watanabe (Da cognição no processo civil), para quem somente por meio da produção de provas exaurida e a ampla participação das partes alcançará a certeza absoluta.

2. Os referidos autores são Giovanni Arietta (I provedimenti d'urgenza, p. 44), Salvatore Satta (Diritto Processuale Civile, p. 503) e Piero Calamandrei (Introdução ao estudo sistemático dos procedimentos cautelares, p. 31).

3. Cf. José Carlos Barbosa Moreira, Tutela de urgência e efetividade do direito, in: Temas de direito processual, p. 91. 
Há também autores com o entendimento contrário, dentre os quais Luiz Fux, que entende que as decisões proferidas em procedimento de cognição sumária não teriam essa aura da instabilidade, pois poderiam revestir-se da estabilidade da coisa julgada. ${ }^{4}$ Calamandrei afirma que "il provvedimento sommario è provvisorio nella formazione, ma definitivo nello scopo; quello cautelare, anche se formato attraveerso una cognizione ordinaria, è provvisorio nel fine". 5

Contudo, a formação de coisa julgada, apesar de a doutrina se debruçar sobre o tema, é uma questão de política legislativa. ${ }^{6}$ No sistema brasileiro, o legislador determina que deve ser analisado o mérito da questão e aí se forma a coisa julgada, independentemente do grau de cognição. Tanto que, se houvesse alguma necessidade de cognição exauriente, não seria admitido no Brasil o procedimento sumário, sumaríssimo e o julgamento antecipado com fundamento no art. 330 do CPC.

Não necessariamente todas as decisões que podem adquirir força de coisa julgada têm essa natureza definitiva e o contrário também pode ocorrer, decisões que possuem natureza definitiva não adquirem a força de coisa julgada. Isso porque a escolha se uma decisão irá adquirir força de coisa julgada é totalmente política, em que devem ser escolhidos dois valores: segurança jurídica e o ideal de justiça.

A segurança jurídica é intrinsecamente ligada à imutabilidade da decisão judicial proferida, enquanto o ideal de justiça é sempre possível de ser alcançado quando se permite o reexame do ato. Não é possível, entretanto, o reexame do ato judicial eternamente, pois a parte que se sagrou perdedora nunca ficará satisfeita e sempre buscará a reforma da decisão. ${ }^{7}$

Feito esse panorama, chegamos à conclusão de que na legislação atual não se pode falar em coisa julgada da tutela diferenciada. Não pela limitação da cognição, mas porque a tutela diferenciada, aqui como posta, não analisa todos os pedidos iniciais. No mesmo sentido, Donaldo Armelin entende, baseando-se nos conhecimentos de Vellani, que a coisa julgada é resultado de escolhas do legislador e do momento em que a sociedade vive. ${ }^{8}$

\footnotetext{
Cf. Luiz Fux. Tutela de segurança e tutela de evidência, p. 70.

Piero Calamandrei, op. cit., p. 15.

Cf. Ricardo de Barros Leonel. Tutela jurisdicional diferenciada.

Eduardo Talamini, Tutela monitória: a ação monitória - Lei 9.079/95, p. 93.

"Nem mesmo a garantia constitucional da coisa julgada impede que algumas decisões judiciais consubstanciadoras de prestação jurisdicional integral não se tornem ungidas da inalterabilidade inerente a esse instituto processual.Isto porque o conceito de coisa julgada material é definido por
} 
No nosso sistema processual, a coisa julgada foi reservada às sentenças de mérito transitada em julgado, após o exame sumário ou exauriente dos fatos e do direito alegado pelas partes. Mas por que a coisa julgada ficou reservada somente às sentenças de mérito? Por um motivo simples: elas dizem o direito e põem fim ao processo, ou seja, correspondem a uma decisão definitiva.

Ora, uma decisão de cognição sumária também diz o direito, também decide uma questão nodal levada pelas partes ao Poder Judiciário e pode pôr fim ao processo caso a parte contrária não se manifeste ou recorrer. ${ }^{9}$ Por que então não se outorgar a força de coisa julgada para esse tipo de decisão?

O Instituto Brasileiro de Direito Processual (IBDP) elaborou um anteprojeto de lei propondo a estabilização da tutela antecipada, outorgando a esta a força de coisa julgada. A ideia proposta era de que, na hipótese de ser dada uma decisão antecipada e as partes se conformarem, não haveria necessidade de continuidade do processo, com a posterior instauração do contraditório. Caso as partes se conformassem com a decisão, essa se estabilizaria, ainda que fosse uma decisão liminar, e seria outorgada força de coisa julgada.

Seria uma tutela sumária não cautelar, pois a decisão não é mais provisória, mas definitiva. Solução igual já se encontra no nosso sistema, quando do julgamento pela revelia. Ora, se o próprio réu não deu continuidade ao processo, não há motivo para ser proferida uma nova decisão que somente irá substituir aquela decisão liminarmente deferida.

A reforma proposta pelo IBDP muda substancialmente o conceito de tutela antecipada, porque a decisão passaria de provisória para definitiva, podendo, inclusive, alcançar o status de coisa julgada.

Sobre esse tema, interessante o pensamento de Donaldo Armelin:

Assim sendo, a adoção de uma tutela jurisdicional diferenciada dessa natureza, implicaria, além de uma opção política nesse sentido, a alteração da dogmática vigente, de modo a permitir de forma clara que

lei e esta, como o texto constitucional, não impõe a sua extensibilidade a todas prestações jurisdicionais" (Donaldo Armelin, Tutela jurisdicional diferenciada, Revista de Processo, p. 47).

9. Conforme Ovídio Araújo Baptista da Silva (Da sentença liminar à nulidade da sentença, p. 21), as sentenças liminares decidem questões nodais e colocam um fim à questão levada nos autos, mas são provisórias, pois pode ser considerada definitiva apenas a decisão passível de trânsito em julgado. Nessa hipótese, a sentença acaba transitando em julgado pela própria preclusão endoprocessual, e não é possível que as partes e o juiz não tratem da questão. Essa decisão, porém, não ganha o status da coisa julgada. 
as decisões, ainda que definitivas, no sentido de permitirem o exame sobre o mérito da ação, emergentes de processos de procedimento propiciador de cognição meramente superficial, não transitam em julgado materialmente, de sorte a inexistir veto ao reexame judicial, em processo de cognição plena e exauriente, das questões nele decididas. Se assim não for, não se estará reconhecendo um tipo diferenciado de tutela jurisdicional no sentido supra acentuado, mas um diferente instrumento de sua prestação, marcado pela sumariedade, sem afetação do resultado comum ao processo de conhecimento. ${ }^{10}$

Quais são os problemas da instabilidade? Ausência de segurança jurídica, a relação entre as partes do processo fica instável, negócios celebrados com terceiros também ficam instáveis, prazos prescricionais, problemática na execução da decisão.

Diante deste cenário resta a pergunta: pode um processo de cognição sumária ter coisa julgada? Leonardo Grecco ${ }^{11}$ e Barbosa Moreira ${ }^{12}$ entendem que não, uma vez que a coisa julgada está estritamente ligada à ideia de cognição exauriente.

Na Alemanha, a ideia de coisa julgada está ligada à amplitude da produção probatória. ${ }^{13}$ No procedimento documental (que é o monitório abrasileirado) essa produção probatória consiste na análise dos documentos colacionados nos autos e, caso o juiz não se convença, é necessário uma investigação mais profunda em um processo de cognição exauriente. Já o référé francês é prioritariamente um procedimento de cognição sumária que dependendo da situação não forma coisa julgada, havendo apenas uma estabilização do provimento.

Bedaque mostra-se contrário ao trânsito em julgado da sentença cautelar:

Proferida a sentença em processo cautelar autônomo, a conclusão poderia ser a mesma: Não obstante posições em sentido contrário, defendendo até mesmo o trânsito em julgado da sentença cautelar e a admissibilidade da ação rescisória, parece mais adequada a posição

10. Cf. Donaldo Armelin, Tutela jurisdicional diferenciada, Revista de Processo, São Paulo, vol. 65, jan.-mar. 1992. p. 48.

11. Leonardo Grecco, Cognição sumária e coisa julgada, p. 7.

12. José Carlos Barbosa Moreira, Miradas sobre o processo civil contemporâneo, in: , Temas de direito processual, p. 49-50.

13. "A norma del§ 322, Abs $1 \mathrm{ZPO}$ il giudicato sostanziale copre solo la pretesa fatta valere con la domanda, mentre non si estende ai fatti materiali accertati ed alle eccezioni fatte valere dal convenuto, salvo che al credito opposto in compensazione per espressa disposizione di legge ( 322, Abs 2), né ai diritti costituenti gli antecedenti lotici di quelli fatti valere. Ai sensi del § 325, Abs 1 ZPO gli effetti del giudicato si producono solo nei confronti delle parti e di coloro che gli sono succeduti nel diritto controverso dopo l'inizio del processo, a meno che non si tratti di sentenza costitutive che hanno efficacia nei confronti di tutti. Tuttavia, tali effetti non si estendono all'erede se costui dimostra di avere ignorato in buona fede la sentenza e la litispendenza" (Livia di Cola, L'efficacia dei provvedimenti sommari nell'ordinamento tedesco, in: Antonio Carrata(org.), La tutela sommaria in Europa: studi). 
segundo o qual a provisoriedade dessa modalidade de tutela jurisdicional não é compatível com a estabilização pretendida. ${ }^{14}$

Isso porque a função da tutela cautelar, ainda que seja a sentença, é apenas assegurar o processo principal. Para o autor,

[...] a coisa julgada constitui qualidade da sentença de mérito proferida no processo cognitivo, não no cautelar. A finalidade desse instituto é essencialmente prática, pois se destina a conferir estabilidade ao julgamento. Seu objetivo é a segurança das relações da vida reguladas pela sentença, que não podem permanecer passíveis de modificações. ${ }^{15}$

Reforçando esse entendimento de Bedaque, temos a doutrina italiana demonstrada em Comoglio et al., que sustenta como nosso procedimentos cautelares "non sono decisori" uma vez que não definitivos e, por essa razão, não formam a coisa julgada. ${ }^{16}$

Para Proto Pisani o provimento judicial que encerra um processo sumário pode apresentar três modalidades, que exemplificamos perante o direito pátrio: 1) pode o provimento ser imutável e proporcionar tutela definitva (envolvendo, desta forma, a mesma utilidade ou utilidade equivalente àquela produzida pela sentença emergente de um processo a cognição plena, como no caso em que se constitui de pleno direito o título exe utivo na ação monitória); 2) pode o provimento estar ungido de coisa julgada formal e oferecer tutela provisória, como é o caso do processo cautelar; 3) pode, afinal, o provimento apresentar tão-somente eficácia executiva ou mandamental antecipadas, como no caso das antecipações de tutea em geral. ${ }^{17}$

Percepção contrária é a de Ovídio Baptista da Silva, que admite expressamente a possibilidade de trânsito em julgado nas sentenças cautelares. ${ }^{18}$

Quanto ao processo monitório, também há uma discussão doutrinária sobre o mandado monitório ter ou não força de coisa julgada. Essa é a tese defendida por

14. José Roberto dos Santos Bedaque, Tutela cautelar e tutela antecipada: tutelas sumárias e de urgência (tentativa de sistematização), p. 157.

15. Idem, ibidem, p. 158.

16. Luigi Paolo Comoglio; Corrado Ferri; Michele Taruffo, Lezioni sul processo civile, p. 370. No sentido contrário, ver Marcelo Lima Guerra, Estudos sobre o processo cautelar.

17. Cf. Rogério Aguiar Munhoz Soares, op. cit., p. 199.

18. "Ora a afirmação de que sendo a ação cautelar puramente instrumental não faz coisa julgada é não só uma conclusão perigosa, como decididamente equívoca, pois, como vimos, os melhores talentos da ciência processual, como é o caso de Calamandrei, indicam a mesma instrumentalidade existente na sentença condenatória, relativamente ao futuro processo de execução. E ninguém negará que a sentena que decide a ação condenatória faça coisa julgada e seja decisão de mérito" (Ovídio Araújo Baptista da Silva, A ação cautelar inominada no direito brasileiro, p. 210). 
Garbagnati, ${ }^{19}$ segundo a qual, para haver uma sumariedade da cognição na fase inicial do processo, essa sumariedade deve decorrer do procedimento, e não da natureza da cognição. Para o referido autor, o decreto ingiuntivo tem natureza idêntica ao do processo ordinario di cognizione, já que os efeitos do mandado monitório seriam os mesmos de uma sentença de proferida em um processo de cognição ordinária. Tratarse-ia de uma cognição parcial, uma vez que não foi ouvido o réu e foi emitido o mandado somente com os fatos narrados pelo autor.

Talamini critica a posição de Garbagnati, argumentando que primeiro é preciso ter em mente que a qualidade de coisa julgada é uma escolha legislativa e que não decorre necessariamente do conteúdo da decisão. Além disso, Talamini afirma que a ideia defendida por Garbagnati de que a cognição seria parcial por se basear apenas na prova documental do autor sem ouvir o réu e, mesmo assim, também exauriente soa contraditória. Isso porque a limitação da cognição afirmada por Garbagnati está ligada à profundidade do exame feito pelo julgado, e, como o exame é feito apenas com os documentos levados pelo autor aos autos, a limitação é evidente, não podendo se falar em cognição exauriente. ${ }^{20}$ Para Talamini, não é necessário outorgar a força de coisa julgada ao mandado monitório, porque para isso ocorrer seria necessária uma prova irrefutável, o que acabaria esvaziando o instituto do procedimento monitório, pois o juiz somente poderia expedir o mandado monitório se ele tiver certeza absoluta do direito do autor.

A decisão proferida na execução que determina ao devedor proceder ao pagamento no prazo de três dias não é sentença e não adquire força de coisa julgada, mesmo que o réu pague o valor e não apresente embargos. Da mesma forma, a decisão que determina a expedição do mandado monitório não tem natureza de coisa julgada, mesmo que não sejam apresentados embargos. ${ }^{21}$

19. Cf. Edoardo Garbagnati, I procedimenti d'ingiunzione e per convalida di sfratto.

20. Eduardo Talamini, Tutela monitória. A ação monitória - Lei 9.079/95, p. 80.

21. Especificamente sobre a natureza do mandado monitório, Talamini afirma que: "No sistema processual civil brasileiro, reservou-se o atributo da coisa julgada às sentenças de mérito transitadas em julgado (art. 467 e 485). O título executivo constituído de pleno direito tem por base simples decisão - e não sentença. Sentença, no processo civil brasileiro, é ato que extingue o processo com ou sem julgamento de mérito (art. 162, § $1^{\circ}$ ). A decisão que concede a tutela monitória é proferida logo no início do processo. Mesmo na hipótese de não serem interpostos os embargos, tal decisão inicial não encerra o processo (nem sua primeira fase, cognitiva): a própria citação (aperfeiçoamento da relação processual, com a formação integral do processo) lhe é posterior. Portanto, e já por isso, não há de se falar em coisa julgada material da decisão concessidade de mandado não embargado. Nem se diga que essa decisão converte-se em sentença. Sentença - repita-se - é ato finalizador do processo e a decisão concessiva da tutela monitória é 
Por fim, ainda existe na doutrina a discussão de se a coisa julgada poderia apenas ser outorgada para os processos de cognição exauriente e não para os processos de cognição sumária. Esse parece ser o entendimento de Eduardo Talamini. Na linha de que a coisa julgada é uma escolha legislativa, ele afirma que o legislador não pode simplesmente escolher a seu bel-prazer quais decisões adquirirão força de coisa julgada e quais não adquirirão. O legislador estaria adstrito aos princípios constitucionais.

Dessa forma, o legislador somente poderia dar força de coisa julgada às decisões em que houve o contraditório ou ao menos tenha sido dada a oportunidade de se manifestar (ainda que o réu não tenha feito). Até esse momento, a conclusão de Talamini parece-nos correta pois, de fato, não é possível outorgar força de coisa julgada à decisão em que sequer foi dada oportunidade da parte se defender. Permitir isso seria dar carta branca e ferir os princípios processuais constitucionais. No entanto, o referido autor afirma também que seria inconstitucional outorgar força de coisa julgada à decisão de cognição sumária pelo simples fato de ser cognição sumária. ${ }^{22}$ Em que pese o respeito ao renomado professor, não podemos concordar com essa afirmação.

Como vimos afirmando, a outorga da coisa julgada é questão de escolha legislativa e não está relacionada à natureza da decisão. É lógico que existem limites que o legislador deva se basear, mas esse limite é justamente o respeito ao contraditório. O fato de ser uma decisão de cognição sumária não lhe retira a possibilidade de transitar em julgado. Inclusive, as decisões dos procedimentos possessórios são de cognição sumária e têm força de coisa julgada, ainda que se argumente que haveria sumariedade da cognição nas ações possessórias, que a

proferida em seu início. Formalmente, e como é óbvio, vai permanecer no início do processo mesmo depois de não interpostos os embargos. A ausência de embargos não tem o condão de deslocar topicamente e alterar a natureza específica da decisão concessiva da tutela monitória. Portanto, esse provimento pode ter função e eficácia semelhantes à da sentença condenatória no processo comum de conhecimento - mas, nem por isso, é senteça" (idem, ibidem, p. 93).

22. "E aqui se põe o óbice à constitucionalidade da atribuição de coisa julgada à decisão monitória quando não há embargos. $\mathrm{O}$ deferimento do mandado, com ouvida unilateral e à base de documentos, importa necessariamente em juízo de cognição sumária (superfical) - diferentemente do que se dá na sentença proferida na revelia. A posterior concessão de oportunidade de embargos, por si e em si, não torna exauriente a cognição já desenvolvida. Não interpostos embargos, apenas e simplesmente a decisão proferida mediante cognição sumária torna-se de pleno direito título executivo - sem qualquer possibilidade de o juiz de ofício revê-la, ainda que convencido de seu desacerto, ou de determinar providências instrutórias (vede item 2.5, adiante). E o instituto da coisa julgada - que tem por essência a imutabilidade - é constitucionalmente incompatível com decisão proferida com base em cognição sumária, sujeita à confirmação" (idem, ibidem, p. 99). 
limitação na cognição seria horizontal, que haveria apenas um corte nos fatos e que a cognição seria exauriente quanto a esses fatos.

Tal argumento igualmente não se sustenta. A cognição nas ações possessórias também é sumária, os fatos ali levadas a juízos não são analisados de forma exauriente (até porque posse é questão de fato e não direito, cabendo ao juiz realizar uma investigação somente sobre os fatos) e, mesmo nas ações possessórias, a decisão adquire força de coisa julgada.

No procedimento do mandado de segurança ocorre o mesmo fenômeno jurídico, a cognição é sumária, o direito do autor tem que ser líquido e certo e não cabe instrução probatória. E a sentença também adquire força de coisa julgada.

Em contraparida, não adotamos o posicionamento exatamente oposto. Certamente, em algumas situações a tutela de cognição sumária adquire força de coisa

julgada, mas em outras não. É o caso do mandado monitório, a decisão cautelar, da tutela antecipada e da decisão de tutela de evidência. Essas decisões são sempre provisórias, aguardando uma confirmação final do Poder Judiciário, e, portanto, não adquirem força de coisa julgada. No máximo, essas decisões são atingidas por uma preclusão endoprocessual, cujos efeitos práticos aproximam-se muito da coisa julgada. Com a preclusão pro iudicato que ocorre o fenômeno da estabilização da tutela diferenciada.

\subsubsection{Estabilização com ou sem formação de coisa julgada}

Tratamos agora da questão da estabilização da tutela diferenciada com ou sem coisa julgada, também comparando com os ordenamentos estrangeiros e afastando o dogma da necessidade de coisa julgada para a estabilização da tutela diferenciada.

Há uma severa crítica à possibilidade de se outorgar força de coisa julgada às tutelas diferenciadas. No entanto, em alguns países esse regime é mais comum. Como asseverado, a coisa julgada não passa de uma escolha legislativa e outorgá-la a diversas situações processuais também é um exercício de política. A coisa julgada tem limites objetivos e subjetivos que devem ser analisados e, além disso, também tem a eficácia preclusiva por excelência. 
Como ensinou Liebman, "é só o comando pronunciado pelo juiz que se torna imutável, não a atividade lógica exercida pelo juiz para reparar e justificar a decisão". ${ }^{23}$ A questão da estabilidade do provimento da tutela diferenciada guarda relação direta com a não obrigatoriedade ou eventualidade do contraditório pleno no modelo das tutelas diferenciadas acima expostas. ${ }^{24}$

“Os efeitos resultantes da tutela sumária não cautelar podem tornar-se definitivos, o que não ocorre com os produzidos pela cautelar; o objeto da tutela sumária é o mérito; já o da tutela cautelar é a verossimilhança e o perigo de dano". ${ }^{25}$

Edoardo Ricci, analisando o art. 273 do CPC, faz uma comparação com o sistema italiano e afirma que naquele país, já nos anos 1990 permitiam a executoriedade provisória, mas de forma imediata, da sentença sujeita a recurso. ${ }^{26} \mathrm{~A}$ decisão proferida no procedimento cautelar italiano não tem força de coisa julgada, não representa uma

23. Enrico Tullio Liebman, Eficácia e autoridade da sentença e outros escritos sobre a coisa julgada, p. 55.

24. Ada Pellegrini Grinover, em estudo sobre as diversas tutelas diferenciada,s fez uma breve análise do grau de estabilidade da tutela sumária em vários países: "Na Alemanha, as injunções interlocutórias constituem títulos que abrem caminho para a execução. Quando submetidas a apelação ordinári, podem levar a suma sentença revestida da autoridade da coisa julgada. A monitória antecipa a formação do título executivo, mas a injunção, mesmo não impugnada, não adquire força de coisa julgada. Na Áustria, as medidas antecipatórias são sempre provisórias. Completamente diferente é o tratamento do référé; o relatório belga afirma que, contrariamente ao que foi defendido no passado, o référé leva á coisa julgada. Somente aduzindo fatos novos podem as partes obter a modificação da decisão anterior (de acordo com a cláusula rebus sic stantibus). Mas um référé constratante com a coisa julgada obtida em processo posterior cai. Normalmente, o référé aguarda-se a decisão final, mas ele constitui um importante ponto de referência para o processo principal, embora não tenha efeito vinculante. O efeito do référé cessa com o eventual julgamento do mérito. $\mathrm{Na}$ Espanha, as peculiaridades da monitória levam sempre a uma sentença de mérito, coberta pela coisa julgada. Mas, na verdade, não existe antecipação na tutela monitória espanhola. Nos demais casos dos chamados 'casos especiais de juízos verbais' não há coisa julgada. Na Itália, a estabilidade da tutela sumária varia conforme os casos. No processo monitório, o decreto injuntivo não impugnado equivale a uma sentença passada em julgado. A condenação com reserva de exceções é imediatamente executiva, produzindo desde logo todos os efeitos de uma sentença de primeiro grau, apelável. Não sendo o provimento impugnado, faz coisa julgada; mas trata-se, aqui, de uma coisa julgada sujeita a condição resolutiva, caso uma sentença futura acolha as exceções reservadas. A antecipação de tutela genérica do art. 700 (inicialmente destinado exclusivamente às cuatelares) é imediatamente executiva, mas a sentença de mérito anula seus efeitos, seja a favor ou contra a antecipação. Também cessa a eficácia do provimento antecipatório, se o processo se extingue sem sentença, por renúncia ou inatividade do demandante. Nos outros casos, a regra geral é de imediata executividade do provimento, que ficará absorvido pela sentença de mérito. Na Grécia, a eficácia executiva dos provimentos antecipatórios é imediata, mas sempre provisória, chegando-se à falar de uma "coisa julgada provisória"” (Ada Pellegrini Grinover, Tutela jurisidicional diferenciada: a antecipação e sua estabilização, in: O processo - estudos e pareceres, p. 95.

25. José Roberto dos Santos Bedaque, op. cit., p. 129.

26. Edoardo Ricci, A aplicação do art. 273 do CPC e seus principais aspectos: reflexões históricas e comparativas, in: Mauricio Zanoide de Moraes; Flávio Luiz Yarshell (orgs.), Estudos em homenagem à professora Ada Pellegrini Grinover, p. 538. "Art. 282. La sentenza di primo grado è provvisoriamente esecutiva tra le parti”. 
preclusão interna do juízo de cognição de cujo é instrumento. O fenômeno que se representa é o da estabilidade do provimento por toda a duração do direito substancial. ${ }^{27}$ Nesse sentido, ensina Massimo Fabiani:

\begin{abstract}
Non solo l'ordinanza non acquista valore di giudicato in altri processi, pur se fra le stesse parti, ma non rappresenta neppure uma preclusione all'interno del giudizio di cognizione cui è strumentale. Il fenomeno che si rappresenta è, allora, solo quello della stabilità dell'effetto del provvedimento per tutta la durata del diritto sostanziale se non viene promosso un giudizio nel quale si chieda l'accertamento pieno di quello stesso diritto; resta poi da valutare se l'iniziativa cautelare intrapresa, non seguita dal giudizio di mérito, possa valere come atto idôneo ad impedire che si verifichi una decadenza. ${ }^{28}$
\end{abstract}

Como a decisão não adquire força de coisa julgada, a autoridade do provimento cautelar não é invocável em um processo diverso (arts. 23 e 669, comma 8), não sendo aplicável à matéria o art. $2.909^{29}$ do Código Civil Italiano, que dispõe sobre a formação da coisa julgada. Ou seja, a decisão não tem força de coisa julgada. É um provimento inidôneo a se estabilizar segundo a regra da coisa julgada e, portanto, a sua estabilização ocorre segundo a regra do direito material, fala-se em uma estabilização de fato.

A tutela cautelar não tem estrutura para formar coisa julgada, mas pode se tornar definitiva no plano material. Isso porque, caso seja cautelar antecipatória e for confirmada no processo principal, ela se torna definitiva e imutável; caso não seja proposta a ação principal, a tutela cautelar ${ }^{30}$ se torna definitiva, mas não imutável.

27. "Infine, non va trascurata la circostanza che talvolta si dispone che il provvedimento interinale rimanga in vita anche successivamente alla pronuncia del provvedimento definitivo e fino al passaggio in giudicato di questo (art. 472 c.c. in riferimento al provvedimento interinale dell'art. 419 c.c). altre volte, invece, si prevede espressamente che lo stesso provvedimento conservi la sua efficacia anche dopo l'estinzione del processo finché non venga sostituito con altro provvedimento emesso dal presidente o dal giudice istruttore a seguito di nuovo processo (art. 189 disp. art. CPC in riferimento al provvedimento interinale dell'art. $708 \mathrm{cpc}$; art. 4, ottavo comma, legge n. 898 1970 come riformato dalla legge n. 74 - 1987)" (Antonio Carratta, Profili sistematici della tutela anticipatoria).

28. Cf. Massimo Fabiani, Il rito cautelare societario (contraddizioni e dubbi irrisolti, Rivista di Diritto Processuale, ano LX (seconda serie), n. 4, p. 1201.

29. “Art. 2909 - L'accertamento contenuto nella sentenza passata in giudicato fa stato a ogni effetto tra le parti, i loro eredi o aventi causa" (1306, 1595; Cod. Proc. Civ. 324).

30. Segundo Peyrano, esse tipo de tutela é autossatisfativo, uma vez que não pode ser considerado cautelar pois uma das suas principais características, a provisoriedade, não está presente. Assim, são tutelas urgentes, sumárias e não cautelares que se estabilizam, mas não se tornam imutáveis, não formam a coisa julgada. 
Um caso especial de tutela cautelar que adquire força de coisa julgada são as denominadas tutelas autossatisfativas ou tutela de segurança. São aquelas situações em que há urgência no pleito levado ao juízo, ou seja, ficou demonstrado o periculum in mora, mas a decisão é irreversível. Nessas situações não há como negar que a decisão cautelar adquire força de coisa julgada, mesmo que proferida em cognição sumária. ${ }^{31}$

Esse instituto é amplamente aplicado em algumas províncias argentinas (Corrientes, La Pampa, Santa Fé) e é aplicado apenas em situações extremamente urgentes e que envolvam direitos fundamentais, como a vida, a saúde e a psique da parte.

Há uma grande discussão sobre a inconstitucionalidade desse tipo de tutela, uma vez que não dá ao réu a possibilidade de apresentar as suas razões e de se defender, violando assim o devido processo legal, o contraditório e a ampla defesa.

Na tutela antecipada é possível fazer uma aproximação com o référé francês e as einstweiligen Verfügungen do direito alemão. Ficou demonstrado que o référé provision, após o deferimento da liminar e se as partes não se manifestarem quanto à continuidade do processo, se estabiliza sem adquirir força de coisa julgada. Além disso, a experiência francesa tem mostrado que o réu somente dá continuidade ao processo quando tem absoluta certeza de que poderá reverter a situação. Caso seu direito não seja assim tão evidente, as decisões tem se estabilizado com cumprimento das obrigações pelo réu.

$\mathrm{O}$ art. 186 quarter do Codice di Procedura Civile ${ }^{32}$ prevê também uma hipótese de estabilização da decisão nos casos em que há a extinção do processo. A decisão conserva então sua eficácia, momento no qual deixa de ser provisória para se tornar

31. "Conclui-se, por oportuno, que a tutela imediata, v. g. que autorize a realização de uma cirurgia ou uma viagem, caracteriza situação fática impossível de ser desfeita, razão por que falecerá ao autor interesse de agir na propositura de outra ação, porque aquilo que ele obteve era tudo quanto poderia auferir da tutela jurisdiional. A fortiori, essa decisão irrevers'vel há de fazer coisa julgada material, malgrado concebida numa cognição sumária" (Luiz Fux, Tutela de segurança e tutela de evidência (fundamentos da tutela antecipada), p. 70).

32. “Art. 186. Esaurita l'istruzione, il giudice istruttore, su istanza della parte che ha proposto domanda di condanna al pagamento di somme ovvero alla consegna, o al rilascio di beni, può disporre con ordinanza il pagamento, ovvero la consegna o il rilascio, nei limiti per cui ritiene già raggiunta la prova. Con l'ordinanza il giudice provvede sulle spese processuali. L'ordinanza è titolo esecutivo. Essa è revocabile con la sentenza che definisce il giudizio. Se, dopo la pronuncia dell'ordinanza, il processo si estingue, l'ordinanza acquista l'efficacia della sentenza impugnabile sull'oggetto dell'istanza. L'ordinanza acquista l'efficacia della sentenza impugnabile sull'oggetto dell'istanza se la parte intimata non manifesta entro trenta giorni dalla sua pronuncia in udienza o dalla comunicazione, con ricorso notificato all'altra parte e depositato in cancelleria, la volontà che sia pronunciata la sentenza". 
definitiva. Interessante notar que o dispositivo legal prevê que a decisão a torna um título executivo, mas não lhe dá força de coisa julgada, pelo contrário, é claro ao afirmar que a decisão poderá ser impugnada (“l'ordinanza acquista l'efficacia della sentenza impugnabile sull'oggetto dell'istanza").

A doutrina dá três interpretações possíveis para a natureza dessa decisão: 1) a decisão conserva apenas a eficácia executiva; 2) a decisão adquire força de coisa julgada, mas de uma forma quantitativa e não qualitativa, ou seja, seria uma presunção pro judicato; 3) a decisão adquire força de coisa julgada da mesma forma que uma sentença.

A primeira parte da doutrina afirma que a decisão conserva apenas a sua eficácia executiva, já que a decisão não adquire força de coisa julgada e pode ser modificada através de recurso ou até mesmo quando for prolatada a sentença. Ela tem essa natureza, haja vista que não foi prolatada dentro de um procedimento de cognição aprofundada, mas, sumária. Essa decisão persiste mesmo depois de extinto o processo principal. ${ }^{33}$ No entanto, esse entendimento é afastado pela própria dicção do referido art. 186 quarter do código italiano, pelo qual a decisão expressamente adquire a eficácia de uma sentença ainda pendente de recurso.

Não há dúvida de que a decisão tem efeitos executivos, tanto que o próprio dispositivo legal afirma que ela pode ser executada. No entanto, essa força executiva não retira a possibilidade de a questão ser discutida em um processo de cognição ordinária com uma sentença definitiva. Ou seja, ela possui eficácia executiva, mas não o accertamento de uma sentença. ${ }^{34}$ Pela solução apresentada pelo legislador é necessário reconhecer a decisão antecipatória como uma investigação plena, mas não definitiva dos fatos e passível de execução. ${ }^{35}$

33. "Proprio perché il provvedimento di tutela anticipatoria in senso proprio è privo di attitudine ad acquiste forza di giudicato anche quando sopravvive all'estinzione del processo, la statuizione in esso contenuta potrebbe essere sempre rimessa in discussione in un futuro processo a cognizione piena, instaurato anche attraverso l'opposizione all'esecuzione di cui all'art. 615 cpc" (Antonio Carratta, op. cit., p. 515).

34. "Affermare, infanti, che il provvedimento qualificato anticipatorio si limita a fornire alla parte istante un titolo esecutivo, che le consenta di procedere all'esecuzione forzata contro il debitore, non significa altro che escludere qualsiasi rapporto di anticipatorietà di questo provvedimento con la sentenzaz finale, se non per quel che riguarda l'incidenza sulla medesima situazione giuridica, lasciando aperto, peraltro, il problema, di rilievo più generale, di come giustificare, in relazione all

'esercizio dell'azione ordinaria di cognizione, la pronuncia di un provvedimento giurisdizionale dotato di sola efficacia esecutiva e non supportato dall'accertamento dell'esistenza del rapporto sottostante" (idem, ibidem, p. 523).

35. "Se si condividono queste considerazioni, allora si può dire che, nei confronti dei provvedimenti interinali l'alternativa posta dal legislatore è chiara: o si nega che al fondo del provvedimento 
A segunda corrente doutrinária defende que tal decisão sofreria de uma preclusão pro judicato e isso para justificar a estabilidade da decisão mesmo que ela não tenha transitado em julgado.

Antonio Carratta critica essa posição doutrinária, em razão da estrutura e natureza da tutela antecipada no processo italiano. Assim como no processo brasileiro, a tutela antecipada italiana é proferida durante um processo de cognição ordinária, que conhece dos fatos plenamente (dos fatos até então trazidos ao conhecimento do juízo), mas não de forma definitiva. A decisão pode ser revogada pelo próprio juízo até o julgamento final do processo. A diferença é que conserva a sua eficácia no caso de extinção do processo.

Para o renomado autor italiano, os efeitos da tutela antecipada são mantidos mesmo em caso de extinção do processo, uma vez que este perdeu a sua "non definitività", não sendo possível revogá-lo. E mais, quando a decisão se converte em um título judicial, nos termos do art. 186 quarter, ela adquire a forma de uma sentença. Não haveria razões, portanto, para não ser outorgada a força de coisa julgada para essas decisões já definitivas, haja vista a extinção do processo. ${ }^{36}$ Isso porque a ação proposta é com o objetivo de conseguir uma sentença final, e, se a decisão da tutela antecipada é qualitativamente igual à sentença, não há motivo para diferenciar essas duas decisões. Sob essa óptica devem ser analisados os limites objetivos e subjetivos da

qualificato come anticipatori vi sia un accertamento pieno anche se non definitivo ed alora si deve anche negare l'esisteza di un rapporto di anticipatorietà di questo provvedimento con lasentenza finale ed indicare il provvedimento con tali caratteristiche come misura sommaria semplificata esecutiva interinale che trova giustificazione, semmai, in pressupposti diversi da quelli propri della tutela anticipatoria; oppure, si ammette che il provvedimento in parola è un tipico provvedimento anticipatorio, ed allora si deve anche ammettere che esse presuppone l'accertamento pieno, anche se non definitivo dei fatti di causa" (idem, ibidem, p. 526-527).

36. "Se si condivdono queste conclusioni, allora mi sembra non si possa negare che, quando, per effetto dell'estinzione del processo, il provvedimento ha perduto la sua provvisorietà o 'non definitività', poiché non è più suscettibile di essere revocato o modificato nel prosieguo del processo, l'accertamento in esso contenuto, e dal giudice raggiunto sulla base dell'esercizio dell'azione ordinaria di cognizione, non presenti alcuna differenza dall'accertamento che si sarebbe conseguito, sull'intera domanda, se le parti nn avessero lasciato estinguere il processo iniziat e con esso il potere decisorio del giudice. D'altro canto, poi, non credo si possano nutrire debbi sul fatto che, quando il provvedimento anticipatorio di cui all'art. 186 quater acquista l'efficacia di una sentenza impugnabile, qualora la parte soccombente on impugni, sullo stesso si forma il giudicato sostanziale proprio delle sentenze. E, se questo avviene rispetto ad un accertamento, quello, appunto, presupposto dall'ordinanza post-istruttoria, che è diventato defintivo perché il prcesso in corso si è estinto o perché la parte intimata ha rinunciato alla pronuncia della sentenzza, non si vede per quale ragione l'identica forza di giudicato non debba conseguir l'accertamento presupposto dagli altri provvedimenti anticipatori, anch'esso divenuto definitivo in conseguenza dell'estinzione del processo" (idem, ibidem, p. 536-537). 
decisão, o que, segundo o autor, não foi feito nos arts. $641^{37}$ e $669^{38}$ do Codice de Procedura Civile. Por fim, Carratta é categórico ao reconhecer a natureza de decisão plena da tutela antecipada:

Non è difficile, a questo punto concludere nel senso che l'efficaca acquista dall'accertamento contenuto nel provvedimento anticipatorio, una volta che sia divenuto definitivo in conseguenza dell'estinzione del processo nel corso del quale è stato pronunciato, sia proprio quella decisoria piena. ${ }^{39}$

Dessa forma, a decisão consiste em um "accertamento pieno anche se non definitivo" 40 que conserva a sua eficácia declarativa do momento em que foi proferida e também é qualitativamente idêntica à eficácia decaratória da sentença, pois outorgou o bem da vida a quem foi procurá-lo no Judiciário.

Ainda, a técnica do condanna con riserva permite que o autor inicie a execução sem uma sentença proferida em um processo de cognição plena e exauriente. Afastando aí o mito da coisa julgada para a execução. ${ }^{41}$ Essa técnica recebeu esse nome por permitir que o autor inicie a execução da decisão judicial liminarmente, mas reservando a possibilidade de o réu demonstrar o seu direito no futuro. Um exemplo é

37. "Art. 641. Se esistono le condizioni previste nell'art. 633, il giudice, con decreto motivato da emettere entro trenta giorni dal deposito del ricorso (1), ingiunge all'altra parte di pagare la somma o di consegnare la cosa o la quantità di cose chieste o invece di queste la somma di cui all'art. 639 nel termine di quaranta giorni (2), con l'espresso avvertimento che nello stesso termine può essere fatta opposizione a norma degli articoli seguenti e che, in mancanza di opposizione, si procederà a esecuzione forzata. Quando concorrono giusti motivi, il termine può essere ridotto sino a dieci giorni oppure aumentato a sessanta. (3) Se l'intimato risiede in uno degli altri Stati dell'Unione europea, il termine è di cinquanta giorni e può essere ridotto fino a venti giorni. Se l'intimato risiede in altri Stati, il termine è di sessanta giorni e, comunque, non può essere inferiore a trenta né superiore a centoventi. (4) Nel decreto, il giudice liquida le spese e le competenze e ne ingiunge il pagamento".

38. “Art. 669. Se nel caso previsto nell'articolo 658 il locatore non chiede il pagamento dei canoni, la pronuncia sullo sfratto risolve la locazione, ma lascia impregiudicata ogni questione sui canoni stessi".

39. Antonio Carratta, op. cit., p. 549.

40. Idem, ibidem.

41. Sobre o mito da coisa julgada no instituto da condanna con riserva delle eccezioni, aponta Luigi Montesano: "Poiché si è in tema di sentenza, converrà forse aggiungere che manca ogni affinità tra la condanna provvisione descritta nell'art. $278, \S 2^{\circ}$ comma CPC e gli accoglimenti sommari allo stato degli atti pur quando questi dispongano il pagamento di somme provvisionale poiché la detta condanna, anche nell'imporre il pecuniario adempimento nei limiti della quantità per cui il giudice ritiene già raggiunta la prova, è una decisione definitiva di merito, e non un ordine sottoposto a più o meno ampia revocailità nel corso del giudizio" (Liugi Montesano, Luci ed ombre in leggi e proposte di tutele differenziate nei processi civile, Rivista di Diritto Processuale, ano XXXIV, n. 4, p. 601). 
o art. 1.462 do Codice Civile, ${ }^{42}$ em que as partes subordinam o direito de apresentar exceção perante o Judiciário ao cumprimento de determinadas obrigações contratuais.

Marinoni assim define-a:

Esta norma disciplina as cláusulas limitativas da apresentação de exceções. São as cláusulas com as quais uma parte - de acordo com o princípio chamado de solve et repete - subordina o próprio direito de suscitar exceções em juízo ao prévio cumprimento das obrigações contratuais. A cláusula assegura a uma das partes o cumprimento imediato da prestação contratual, obtido através da suspensão provisória dos meios de tutela predispostos pelo ordenamento. A exceção do réu, em outras palavras, somente poderá ser conhecido pelo juiz depois da condenação, que é considerada, por isso mesmo, uma condenação com reserva. ${ }^{43}$

Quanto à possibilidade de formação de coisa julgada, Garbagnati explica:

In conclusione, il decreto dlingiunzione contiene, a mio aviso, un provvedimento giurisdizionale di natura dichiarativa, identico per natura al provvedimento del giudice contenuto in un'ordinaria sentenza definitiva di condanna: e ciò, nonostante la forma diversa da quella prescrita dal legislatore per il provvedimento che chiude un processo ordinario di cognizione. L'efficacia di cosa giudicata del decreto d'ingiunzione è soggeta ad una condicio iuris, non diversamente dall'efficacia di cosa giudicata della sentenza pronunciata in un processo ordinario di cognizione, che presuppone la preclusione di tutti i mezzi d'impugnazione previsti nell'art. 324. La sommarietà della cognizione che precede la pronuncia del decreto incide quindi sulla struttura del procedimento d'ingiunzione e ciò sulla forma e sulla sequenza degli atti coordinati al provvedimento finale de giudice, ma non esclude che attraverso il loro svolgimento si pervenga all'esercizio di quella medesima giurisdizione dichiarativa, del cui concreto essercizio è instrumento il processo ordinario di cognizione; cosichè lo scopo del procedimento in esame è di pervenire piu rapidamente alla formazione della cosa giudicata, quand sia probabile che la posticipazione della provocazione al contradittorio consenta la chiusura del processo, senza una reazione della parte ingiunta. ${ }^{44}$

42. “Art. 1.462. Clausola limitativa della proponibilità di eccezioni - La clausola con cui si stabilisce che una delle parti non può opporre eccezioni al fine di evitare o ritardare la prestazione dovuta, non ha effetto per le eccezioni di nulittà, di annullabilità e di rescissione del contratto. Nei casi in cui la clausola è efficace, il giudice, si riconosce che concorrono gravi motivi, può tutavia sospendere la condanna, imponendo, se del caso, una cauzione".

43. Luiz Guilherme Marinoni, Tutela antecipatória, julgamento antecipado e execução imediata da sentença. p. 35.

44. Edoardo Garbagnati, Il procedimento d'ingiunzione, p. 27 
No sistema cautelar espanhol, há também uma diferenciação entre a sentença transitada em julgado e a mera estabilização da decisão. ${ }^{45}$ A medida cautelar ocorre quando o processo não foi definido com sentença ou se definido por sentença, se não foi iniciada a execução do auto de condenação. Mesmo que a sentença não tenha transitado em julgado a parte pode iniciar a sua execução, ainda que provisória.

Por fim, no sistema cautelar brasileiro a decisão cautelar é por essência instrumental e provisória, durando seus efeitos até a prolação da sentença no processo ordinário ou na execução. A sua instrumentalidade é tão latente que se não for proposta a ação principal no prazo de trinta dias da efetivação da liminar, a decisão deverá ser cassada e seus efeitos interrompidos. ${ }^{46}$

Contudo, uma parte da doutrina não considera dois dipositivos legais que tratam das medidas provisoniais que podem ser decretadas pelo juiz: os arts. 888 e 889 do CPC que preveem medidas provisoniais e que possuem caráter satisfativo.

Analisando a fundo cada uma das hipóteses previstas nos incisos do art. 888 do diploma processual chegamos à conclusão de que somente três dessas são plenamente satisfativas, não necessitando da propositura de uma ação posterior. São elas as hipóteses dos incisos II (entrega de bens de uso pessoal), VII (educação dos filhos) e VIII (interdião ou demolição de prédio). ${ }^{47}$

45. "Muovendo dalla prima fattispecie, si osserva he la legge distingue tra la sentenza passata in giudicato formale e la sentenza che di tale stabilità sia ancora priva (art. 207, terzo e quarto comma), senza che rilevi il suo contenuto (di merito o di rito). Mentre nella prima ipotesi l'alzamiento si mostra necessario e si impongono la sua pronuncia d'ufficio - per mezzo del Secretario judicial - e, se del caso, la liquidazione dei danni eventualmente provocati, per il caso di sentenza non ancora passata in giudicato è sÍ prevista la revoca d'ufficio, ma viene al contempo concessa alla parte soccombente la facoltà di instare al giudice la conservazione della misura cautelare (art. 744, primo comma). Sulla richiesta il giudice, sentite le parti e valutate le circostanze, decide con auto se procedere alla revoca oppure al mantenmento o alla modifica del provvedimento, previo aumento della cauzione. Poiché la sentenza di rigetto è di regola in contraddizione con la sussistenza del fumus, si ritiene si tratti di una ipotesi in cui l'aumento della cauzione supplisce alla carenza di altro pressupposto della cautela" (Fabio Cossignani, Brevi note in tema di tutela cautelare nella ley de enjuiciamiento civil, in: Antonio Carrata(org.), La tutela sommaria in Europa: studi).

46. É o que se conclui da leitura de três dispositivos legais: "Art. 806. Cabe à parte propor a ação, no prazo de 30 (trinta) dias, contados da data da efetivação da medida cautelar, quando esta for concedida em procedimento preparatório"; "Art. 807. As medidas cautelares conservam a sua eficácia no prazo do artigo antecedente e na pendência do processo principal; mas podem, a qualquer tempo, ser revogadas ou modificadas"; “Art. 808. Cessa a eficácia da medida cautelar: I - se a parte não intentar a ação no prazo estabelecido no art. 806".

47. Cf. Eduardo Henrique de Oliveira Yoshikawa, Tutela de urgência definitiva? Medidas autossatisfativas (Argentina), medidas provisonais (Brasil) e a proposta de estabilização da antecipação de tutela. 
Quanto ao mandado monitório, a discussão na doutrina igualmente é acirrada. Redenti $^{48}$ não sustenta a ocorrência da coisa julgada, mesmo que não tenham sido apresentados os embargos pelo réu. Porém, não pode ser rediscutido o crédito que já foi declarado e reconhecida a existência pelo Poder Judiciário. A esse fenômeno Redenti chama de preclusão pro iudicato do decreto d'ingiunzione.

Aqui cabe a seguinte pergunta: é realmente necessário o trânsito em julgado? Considerando que todo o conjunto sistemático já assegura à parte a execução da decisão de cognição sumária?

Reiteramos que a coisa julgada não passa de uma opção legislativa. Os efeitos práticos da coisa julgada, com absoluta certeza, são muito importantes, já que conferem segurança jurídica à decisão. Contudo, quais decisões podem ser objeto de coisa julgada ou não é uma escolha legislativa. Nesse sentido, é mesmo necessária a coisa julgada para oferecer segurança e estabilidade às decisões?

Marinoni é claro ao afirmar que o mito da coisa julgada tende a desaparecer, porque não seria mais possível aguardar a coisa julgada material para a realização de direitos. ${ }^{49}$ Dessa forma, para uma parte da doutrina o fator tempo não necessariamente é preciso para conferir estabilidade às decisões judiciais, o que mostraria que o procedimento ordinário não é adequado para a solução de todos os conflitos levados a juízo. ${ }^{50}$ Esse tipo de decisão aproxima-se mais das tutelas sumárias não cautelares, que não são provisórias e não são instrumentais.

Diante de todo o exposto, nos resta a pergunta: o que leva o legislador a escolher uma situação para adquirir força de coisa julgada e outra não? Uma das respostas possíveis é a existência das garantias processuais, tais como o contraditório e a ampla defesa, que dão oportunidade às partes de exporem as suas razões e da matéria ser investigada profundamente.

Ainda, afirma-se que a coisa julgada somente poderia ser outorgada a decisões que estivessem presentes todas as garantias constitucionais - contraditório, ampla defesa, devido processo legal - e que isso somente poderia ocorrer nos processos de

48. Cf. Enrico Redenti, Diritto processuale civile.

49. Cf. Luiz Guilherme Marinoni, Antecipação da tutela, p. 50. Semelhantemente, Teresa Arruda Alvim Wambier afirma: "Hoje, à luz dos valores e das necessidades contemporâneas, se entende que o direito à prestação jurisdicional é o direito a uma prestação efetiva e eficaz. Na verdade, pouco importa se tenha sido concedida por meio de sentença transitada em julgado!” (Teresa Arruda Alvim Wambier, Da liberdade do juiz na concessão de liminares e a tutela antecipatória, in:____ Aspectos polêmicos da antecipação da tutela, p. 483-455).

50. José Rogério Cruz e Tucci, Tempo e processo, p. 120. 
cognição plena e exauriente, pois apenas nesses tipos de processo estariam resguardadas as respectivas garantias constitucionais. E a coisa julgada, por ser o mais alto grau de estabilidade dos atos judiciais, somente poderia ser outorgada em processos de cognição plena e exauriente. Contudo, vimos que a tutela diferenciada em nada fere os princípios e garantias constitucionais. Eles são respeitados e equilibrados com outros princípios constitucionais.

Argumenta-se ainda que a tutela diferenciada (especialmente a tutela antecipada e a cautelar) teria caráter provisório em razão da sua natureza, pois é feita para ser "substituída" pela decisão final. No entanto, se as ideias de que apenas decisões provenientes de processos de cognição plena e exauriente poderiam adquirir força de coisa julgada, tal exigência não seria efetiva nem útil, e o processualista voltaria a pensar no processo não mais como um instrumento para efetivação do direito material, mas como um fim em si.

Se assim fosse, não poderia ser admitido o julgamento antecipado, tanto por revelia quanto por ausência de impugnação específica, e o procedimento sumaríssimo dos juizados especiais também não seria admitido. Diga-se o mesmo do mandado de segurança e das ações possessórias.

Muitas vezes, a sentença proferida ao longo do processo ordinário coincide com a decisão sumária outorgada liminarmente, porque, para a concessão da tutela antecipada, um dos requisitos é a existência da verossimilhança das alegações. ${ }^{51}$ Esta ocorre sobre os fatos narrados na inicial, sem uma investigação profunda acerca deles. O julgador se convence apenas pela narrativa apresentada pelo autor de que, a partir da própria experiência, a veracidade dos fatos é provável. Esses mesmos fatos verossímeis devem se encaixar na norma de direito material, que autorizará o julgador a deferir a liminar e atender o interesse do autor. Ao longo do processo em que forem realizadas todas as provas necessárias em que esse juízo de verossimilhança, poderá se converter em juízo de certeza ou não. Ou seja, para alçar o juízo de verossimilhança

51. Ferrucio Tommaseo afirma que no caso de antecipação de tutela a sentença de mérito se fundamenta nos mesmos fatos narrados na inicial para a concessão da liminar: "Infatti, affermare che la tecnica dell'anticipazione si fonda sulla circostanza che un provvedimento da pronunciarsi prima della sentenza di merito investe, almeno parzialmente, la medesima materia destinata ad essere oggetto di tale sentenza, significa in definitiva attribuire il giusto rilievo all'anticipazione deglieffetti e quindi all'elemento oggettivo che abiam visto essere determinante ai fini dell'individuazione dei provvedimenti anticipatori" (Ferruccio Tommaseo, I provvedimenti d'urgenza. Struttura e limiti della tutela anticipatoria, p. 47). 
ao juízo de certeza, são utilizadas duas técnicas processuais: a instrução probatória e as regras de participação do ônus da prova. ${ }^{52}$

Podemos entender que a outorga da coisa julgada é uma questão de escolha legislativa, cabendo ao legislador a escolha por qual decisão, de modo que a possibilidade de a tutela antecipada se estabilizar com formação de coisa julgada existe na hipótese do julgamento por revelia, conforme determina o art. 330 do CPC.

Em projeto já apresentado pelo IBDP está prevista a possibilidade de conferir trânsito em julgado para as decisões liminares concedidas caso o réu se conforme com a decisão. ${ }^{53}$ Aqui é importante analisar a possibilidade de se conferir trânsito em julgado para as decisões liminares ou se apenas a estabilização endoprocessual, como existente nos ordenamentos francês, italiano e alemão, já seria suficiente. No referido projeto legal, a ausência de impulso processual pelo interessado (no projeto, o réu) já mostraria a sua concordância com a decisão judicial e, dessa forma, seria conferido ao ato judicial o caráter definitivo das sentenças, tornando-se imutáveis os seus efeitos pela formação de coisa julgada. ${ }^{54}$ Com essa medida não mais existiria insegurança jurídica, pois a decisão liminar adquiriu força de coisa julgada produzindo a partir de então os seus efeitos.

52. Alex Costa Pereira, ao tratar do assunto, afirma que o juízo de verdade alcançado ao final do processo é fruto das garantias processuais e da ampla instrução probatória, mas que ele não necessarimente seja "melhor" que o juízo de verossimilhança: "Das considerações até agora tecidas em relação à reconstrução dos fatos no processo, a partir dos quais o juiz exerce com legitimidade a função de pacificador social subrogada, com exclusividade, pelo Estado administrador da justiça, chega-se à constatação de primeira importância no desenvolvimento do trabalho: a certeza jurídica que se obtém no processo e que confere legalidade e estabilidade à decisão que põe fim à crise de direito material levada à solução pelo poder judiciário, é invariavemente vinculada a manifesto juízo de verossimilhança, o qual, por meio de técnicas processuais, é usinado no transcurso do procedimento cognitivo completo e fictamente alçado à condição ou status de juízo da verdade. E essa artificial transformação da verossimilhança em verdade jurídica é materializada, de forma geral, com a realização efetiva das garantias constitucionais que tutelam o processo civil brasileiro, especialmente a ampla defesa e o contraditório" (Alex Costa Pereira, op. cit., p. 112).

53. Os detalhes sobre o referido projeto legal são explicadas no sexto capítulo deste trabalho.

54. "Sob esse ângulo analítico, percebe-se que a perenidade da irresignação do sujeito processual, agora instrumentalizada na impugnação ao juízo decisório do litígio, pode ser enquadrada no conceito mais amplo de contestação à pretensão jurisdicional do adversário, sempre com vistas à correta - em seu entender - declaração da vontade concreta da lei pelo julgador. A ausência do impulso processual necessário à manutenção da incerteza jurídica no embate, identificada na inércia e renúncia da parte derrotada ao direito de impugnar a decisão de solução da controvérsia e que denota sua aquiescência com a jurídica solução formulada pelo órgão judicial, confere ao ato decisório definidor da demanda também a condição de figura definitiva da crise de cooperação existente no processo, cujos efeitos substanciais se tornam imutáveis pela formação da coisa julgada material" (idem, ibidem, p. 133). 
Igualmente, há a possibilidade de a decisão não adquirir força de coisa julgada e apenas adquirir uma estabilização endoprocessual. A estabilidade decorreria da inexistência e desnecessidade de continuidade do processo de cognição plena e exauriente, deixando de ser a decisão instrumental e provisória para passar a ser definitiva. A escolha pela estabilização da tutela diferenciada faria com que o legislador abrisse mão da segurança jurídica, trazida pelo contraditório pleno e pela ampla instrução probatória - que estariam presentes apenas no processo de cognição plena e exauriente, para alcançar uma decisão efetiva.

Assim, se não for dado impulso processual ao processo, seja pela ausência de impugnação ou pela ausência de instauração do processo de cognição plena, a decisão adquirirá a coisa julgada formal ou simplesmente a preclusão endoprocessual, que implica a impossibilidade de mudança da decisão. ${ }^{55}$

\subsection{Sucumbência}

A sucumbência é a condenação que o juiz dá a parte que perdeu como um meio de a "punir" por ter levado a questão ao Judiciário em vez de resolvê-la no âmbito extrajudicial. ${ }^{56}$ Ela consiste na condenação da parte que perdeu ao pagamento dos

55. “Assim, imediatamente após o trânsito em julgado da decisão sumária dotada de autonomia - o que se pode dar, exemplificativamente e a depender de especificidades procedimentais aplicadas pelo legislador ao disponibilizar a técnica no sistema processual, pela preclusão da decisão que concedeu a tutela antecipada ou pelo decurso do prazo peremptório para ajuizamento da ação principal pelo autor ou pelo réu -, deve ser a estabilidade da decisão conduzida pela coisa julgada formal, ou seja, pela imutabilidade da decisão como ato jurídico processual interno ao processo e limitado aos seus sujeitos parciais" (idem, ibidem, p. 147).

56. Existem três correntes doutrinárias sobre a natureza da verba sucumbencial. A primeira é a teoria do ressarcimento, concebida por Weber, a qual procurava uma forma de ressarcir o vencedor. A segunda teoria é a da pena, sustentada por Henneman, para quem "causa específica das despesas para a defesa do direito é a não evidência do direito mesmo, o que só se torna evidente em juízo, Assim, aquelas despesas deveriam ficar a cargo daquele que se sujeita ao direito do vencedor. Certo, com a declaração do direito pelo juiz, o ataque ou a negação direito aparece como injusto, mas não como injustificado, pois, enquanto o direito de ação é discutível, a declaração judicial em favor do vencedor - que coincide com a opinião do juiz - cria um direito formal que, sendo coisa diversa do direito efetivo, não poderia ser conhecido pelo sucumbente antes da instauração da lide" (Yussef Said Cahali, Honorários advocatícios). Por fim, há a teoria da sucumbência, que se baseia na clássica ideia chiovendina de que o Poder Judiciário deve entregar a tutela jurisdicional da forma mais ampla possível, recompondo o dano com a sua maior integralidade - " [...] a justificação desse instituto está em que a atuação da lei não deve representar uma diminuição patrimonial para a parte a cujo favor se efetiva. Por ser interesse do Estado que o emprego do processo não se resolva em prejuízo para quem tem razão e por ser interesse do comércio jurídico que os direitos tenham o valor, tanto quanto possível, nítido e constante" (idem, ibidem). 
honorários do advogado da parte contrária, bem como no pagamento das custas e despesas que a outra parte teve no decorrer do processo.

Ainda, a condenação em sucumbência está ligada à máxima chiovendiana de "dar a quem tem razão tudo aquilo e exatamente aquilo a que teria direito se não fosse necessário o processo" ${ }^{" 57}$. Ou seja, a fixação das verbas sucumbenciais também tem o escopo de restituir o autor a posição original antes de ter de ajuizar uma ação judicial.

Além da adoção da teoria da sucumbência, que se fundamenta na ideia de Chiovenda de reparar integralmente o dano, há ainda, no art. 20 do CPC a ideia de que a sucumbência também deve ficar a cargo daquele que deu origem à necessidade de se procurar o Poder Judiciário. É o denominado princípio da causalidade, aquele que deu causa à propositura da ação deverá arcar com todas as despesas e honorários. ${ }^{58}$

Não há dúvida de que o legislador brasileiro bebeu na fonte chiovendiana. No entanto, a adoção do critério objetivo - ou seja, de quem perdeu a ação ter de pagar desconsidera um fator importante: a intenção do autor italiano era evitar o ato antijurídico e ressarcir quem tinha razão. Uma vez que a parte tenha razão no seu pleito, reconhece-se que ela é merecedora de pretensões e direitos subjetivos e que o fato de a outra parte ter resistido ao cumprimento da obrigação a ponto de a parte procurar o Poder Judiciário.

A sucumbência é fixada na sentença e pode ter seu valor aumentado em caso de interposição de recurso manifestamente improcedente. Ela existe tanto para punir o litigante aventureiro ${ }^{59}$ quanto para aumentar a condenação em caso de réu que obsta o bom desenvolvimento do processo, podendo este, inclusive, ser multado conforme autoriza o art. 22 do CPC. ${ }^{60}$

57. Giuseppe Chiovenda, Instituições de direito processual civil, vol. I, p. 207.

58. Ovídio Araújo Baptista da Silva. Responsabilidade pela sucumbência no Código de Processo Civil, in: , Da sentença liminar à nulidade da sentença, p. 132.

59. “Art. 18. O juiz ou tribunal, de ofício ou a requerimento, condenará o litigante de má-fé a pagar multa não excedente a um por cento sobre o valor da causa e a indenizar a parte contrária dos prejuízos que esta sofreu, mais os honorários advocatícios e todas as despesas que efetuou".

60. "Art. 22. O réu que, por não arguir na sua resposta fato impeditivo, modificativo ou extintivo do direito do autor, dilatar o julgamento da lide, será condenado nas custas a partir do saneamento do processo e perderá, ainda que vencedor na causa, o direito a haver do vencido honorários advocatícios". 
A lei dispõe nas hipóteses de confissão e reconhecimento do pedido formulado pelo autor que deverá ficar a cargo da pessoa que desistiu o pagamento de referidas verbas sucumbenciais. ${ }^{61}$

Considerando pura e simplesmente o princípio da causalidade, mesmo nas hipóteses de reconhecimento do pedido (não de confissão, haja vista que essa somente ocorre na fase probatória) e seguindo criteriosamente nossa legislação processual, seria imperiosa a condenação do réu ao pagamento de sucumbência, pois ele não adimpliu a sua obrigação, sendo necessária a propositura de ação e a intervenção do Poder Judiciário.

Contudo, esse princípio é comumente abrandado, diminuindo-se o valor dos honorários advocatícios fixados, já que não foi necessária a plena atuação do Poder Judiciário - o advogado não atuou plenamente e a controvérsia foi resolvida de forma rápida.

No caso da tutela diferenciada, em que o réu não contestou ou não apresentou recurso manifestamente improcedente, a ausência de condenação em sucumbência pode servir como um incentivo ao cumprimento imediato das decisões judiciais. Essa ausência de condenação do réu pode ser contraditória se comparada à ideia chiovendiana de reconstituir a posição patrimonial do autor ao que era antes da propositura da ação judicial. No entanto, é uma medida muito boa por incentivar o réu a não apresentar contestação inútil (quando ele de fato não tenha nenhuma razão) e evitar, assim, o custo do processo e entregando a tutela jurisdicional de forma mais célere. A tutela diferenciada, nessas condições, atinge o ápice da sua efetividade. A ausência de condenação em sucumbência seria uma sanção positiva, ${ }^{62}$ ou seja, o réu é premiado por cumprir a decisão judicial.

$\mathrm{Na}$ proposta de estabilização da tutela antecipada inicialmente elaborada pelo IBDP, havia a previsão de não pagamento de custas e honorários de sucumbência caso o réu não desse continuidade ao processo. No processo monitório há uma previsão

\footnotetext{
61. “Art. 26. Se o processo terminar por desistência ou reconhecimento do pedido, as despesas e os honorários serão pagos pela parte que desistiu ou reconheceu".

62. Talamini trata exatamente desse tema: "Emprega-se sanção 'positiva' ou 'premial'. Oferta-se benefício destinado a induzir psicologicamente o réu a cumprir o mandado e abreviar o curso do processo. Nesse passo, tal mecanismo enquadra-se no mesmo gênero de instrumentos de 'pressão psicológica' em que se incluem os 'meios processuais coercitivos' (prisão civil, multa diária etc).: a indução psicológica pode fazer-se tanto através da ameaça de consequências gravosas para o caso de descumprimento, quanto pela promessa de prêmio se respeitado o comando" (Eduardo Talamini, op. cit., p. 142).
} 
idêntica, também para desincentivar o réu a dar continuidade desnecessariamente ao processo. ${ }^{63}$

Desta forma, enxergamos como a ausência de condenação em verbas sucumbenciais como um dos meios de incentivo ao réu para não litigar. Se ele não estiver seguro de seu direito e ainda tiver o estímulo de não ser condenado em custas e honorários, provavelmente, ele não contestará a ação e concordará com o pedido do autor, evitando mais um processo.

63. “Art. 1.102-C. No prazo previsto no art. 1.102-B, poderá o réu oferecer embargos, que suspenderão a eficácia do mandado inicial. Se os embargos não forem opostos, constituir-se-á, de pleno direito, o título executivo judicial, convertendo-se o mandado inicial em mandado executivo e prosseguindo-se na forma do Livro I, Título VIII, Capítulo X, desta lei. $\S 1^{\circ}$ Cumprindo o réu o mandado, ficará isento de custas e honorários advocatícios”. 


\subsection{Fundamentação da decisão}

O dever de fundamentação das decisões judiciais está previsto no art. 93, inciso IX, da Constituição Federal, ${ }^{64}$ em que o julgador é obrigado a fundamentar as suas razões jurídicas para o proferimento de determinada decisão. Trata-se de uma garantia do Estado Democrático de Direito. Essa garantia foi levada à condição de status constitucional não somente no Brasil, mas em outros países democráticos que também viram a necessidade de se exigir a fundamentação das decisões judiciais como forma de garantir direito às partes do processo, ainda que não esteja prevista na constitucionalmente, como na Alemanha, onde a fundamentação seria uma consequência lógica dos demais princípios constitucionais.

No Brasil, conforme Barbosa Moreira, a fundamentação da decisão tem raízes no Código Filipino, ${ }^{65}$ no qual o juiz que não procedesse a ela era condenado ao pagamento de multa a favor da parte. Por outro lado, há o princípio do livre convencimento motivado, decorrente do art. 131 do CPC, ${ }^{66}$ que dá liberdade ao juiz para decidir as questões levados no processo, desde que suas decisões sejam motivas, respeitando o dispositivo constitucional. Não há uma obrigatoriedade de como deve ser essa fundamentação, que varia muito no caso concreto, chegando a ter situações em que o juiz se limita a fazer referência às razões expostas pelo autor.

Contudo, essa laconicidade que se tornou comum nas decisões judiciais não é a mais correta. O julgador deve decidir os pontos essenciais das questões levadas explicando ponto por ponto. Logicamente, não se espera uma tese de doutorado sobre

64. “Art. 93. IX - Todos os julgamentos dos órgãos do Poder Judiciário serão públicos, e fundamentadas todas as decisões, sob pena de nulidade, podendo a lei limitar a presença, em determinados atos, às próprias partes e a seus advogados, ou somente a estes, em casos nos quais a preservação do direito à intimidade do interessado no sigilo não prejudique o interesse público à informação".

65. "E para as partes saberem se lhes convém apelar, ou agravar das sentenças definitivas, ou vir com embargos a elas, e os Juízes da mor alçada entenderem melhor os fundamentos, por que os Juízes inferiores se movem a condenar, ou absolver, mandamos que todos nossos Desembargaodres, e quaisquer outros julgadores, ora sejam letrados, ora o não sejam, declarem especificamente em suas sentenças definitivas, assim na primeira instância, como no caso da apelação, ou agravo, ou revista, as causas, em que se fundaram a condenar ou absolver, ou a confirmar, ou revogar" (José Carlos Barbosa Moreira, A motivação das decisões judiciais como garantia inerente ao estado de direito, in: Temas de direito processual, p. 113).

66. “Art. 131. O juiz apreciará livremente a prova, atendendo aos fatos e circunstâncias constantes dos autos, ainda que não alegados pelas partes; mas deverá indicar, na sentença, os motivos que Ihe formaram o convencimento". 
cada um dos temas, mas as razões que levaram o julgador a proferir tal decisão e o funamento jurídico que o sustenta. ${ }^{67}$

Com a possibilidade da estabilização da tutela diferenciada com ou sem formação de coisa julgada, é necessário analisar também a garantia da fundamentação. Essa análise é fundamental pois, ao possibilitar a outorga da coisa julgada às decisões de cognição sumária (ou a sua simples estabilização), a fundamentação da decisão deve ser completa a fim de evitar qualquer nulidade ou prejuízo para o réu ou até para o autor.

Muitas vezes, o julgador se limita a deferir a cautelar "haja vista que estão presentes os requisitos legais", pois os elementos essenciais da decisão serão analisados profundamente durante a tramitação do processo, e somente após a instrução probatória o julgador se convencerá dos fatos alegados na inicial e com isso irá proferir a sentença decidindo cada um dos pontos. No entanto, com a possibilidade de estabilização da tutela diferenciada não será suficiente essa "fundamentação" lacônica, sendo necessário que o julgador a aprofunde em cada uma das questões levadas na inicial, já que essa decisão poderá vir a ser a resposta final que o Poder Juidiciário outorgará à parte. ${ }^{6}$

Também é necessário analisar o fenômeno de quando o julgador decide apenas uma parte dos pedidos realizados pelo autor na inicial. E não só da verossimilhança dos fatos e alegações, mas também quando a decisão judicial baseou-se na urgência do pedido feito na inicial, e o julgador não tinha a verossimilhança dos fatos, somente a urgência do pedido (e o risco de perecimento do direito) e o fumus boni iuris (que não é tão forte quanto à verossimilhança das alegações).

67. “A intensidade da motivação exigida nas decisões judiciais varia de acordo com o caso concreto e deve ser avaliada conforme os ditames da razoabilidade. A exigência deve cingir-se aos elementos essenciais ao amparo da decisão, sem exageros mas, também, sem omissão quanto a pontos nucleares" (Bruno Vasconcelos Carrilho Lopes, Tutela antecipada sancionatória (art. 273, inc. II, do Código de Processo Civil), p. 69).

68. “Com a mudança de perspectiva de atuação da tutela sumária, que potencialmente poderá representar a resposta final do Estado-juiz à crise de direito material que lhe foi submetida, aflora sobremaneira o dever de motivação a ser observado em todo e qualquer pronunciamento judicial que carregue alguma carga de decisão na esfera jurídica das partes - processual ou material. Sendo certo que a decisão que antecipa os efeitos da tutela final almejada pelo demandante deve ser congruente aos limites de sua pretensão definitiva, não se pode olvidar daquelas hipóteses em que o provimento sumário é concedido em menor extensão de efeitos em comparação àqueles que serão produzidos ao final do processo com o acolhimento integral da tese jurídica do autor" (Alex Costa Pereira, op. cit., p. 125). 
Por fim, há a já abordada hipótese do direito evidente, em que é concedida a tutela sem o requisito da urgência, baseando-a apenas na evidência do direito pleiteado pelo autor.

São três hipóteses diversas, mas que guardam na essência a característica da sumariedade na cognição e podem se estabilizar com ou sem formação de coisa julgada. Como a decisão poderá se tornar definitiva, é necessário que o juiz fundamente adequadamente a decisão, não se limitando a afirmar que "estão presentes os requisitos”. Isso porque será necessário que

o magistrado expressamente destacar se o provimento sumário concedido abrange todos os efeitos da tutela final almejada pelo demandante, ou se está limitado a um ou alguns de seus efeitos, delimitando exatamente a área de estabilização da tutela antecipada. ${ }^{69}$

Assim, a necessidade de exigência de fundamentação da decisão também está extremamente ligada à garantia de outras garantias processuais, dentre elas, a imparcialidade do juiz. Apenas com a análise do juiz e a exposição de seus motivos será possível analisar se o juiz foi ou não imparcial, se o julgamento da ação foi uma análise objetiva dos fatos e do direito ou se o juiz tornou-se "parte" do processo, advogando em nome de uma.

Da mesma forma, somente pela fundamentação da decisão é possível analisar a legalidade da decisão, pois só assim a parte pode saber quais foram as razões que fundamentaram a decisão e se elas estão de acordo com a lei.

Trata-se, por fim, também do direito das partes do contraditório pleno, de elas serem ouvidas pelo juiz e terem a certeza de que essas razões foram analisadas pelo julgador quando da prolação da sentença. ${ }^{70}$ Nesse sentido, eis o ensinamento de Barbosa Moreira de como a fundamentação das decisões são essenciais para as partes

69. Idem, ibidem, p. 125-126. O autor justifica na sequência a necessidade do dever de fundamentação adequado das decisões judiciais: "Ganha força, assim, a necessidade de se conhecer exatamente, e sem exitações, o conteúdo do provimento que nasce provisório, mas que pode se tornar a palavra definitiva do judiciário sobre a controvérsia apresentada à solução estatal, a fím de se evitar que a técnica apresentada se transforme em indesejável fonte de incertezas e insegurança nas relações intersubjetivas dos cidadãos. E para que o conteúdo da decisão judicial seja devidamente aclarado pelo seu prolator, outro caminho não há senão o do cumprimento estrito do dever constitucional de motivação das decisões judiciais" (idem, ibidem).

70. José Carlos Barbosa Moreira, A motivação das decisões judiciais como garantia inerente ao estado de direito, in: Temas de direito processual, pp.116-117. 
"fiscalizarem" se o Poder Judiciário está ou não aplicando a legislação da forma correta:

\begin{abstract}
É preciso que o pronunciamento da Justiça, destinado a assegurar a inteireza da ordem jurídica, realmente se funde na lei; e é preciso que esse fundamento se manifeste, para que se possa saber se o império da lei foi na verdade assegurado. A não ser assim, a garantia torna-se ilusória caso se reconheça ao garante a faculdade de silenciar os motivos por que concede ou rejeita a proteção na forma pleiteada, nenhuma certeza pode haver de que o mecanismo assecuratório está funcionando corretamente, está deveras preenchendo a finalidade para o qual foi criado. ${ }^{71}$
\end{abstract}

Apesar da previsão constitucional da necessidade da fundamentação, é sempre bom ressaltar esse princípio (que muitas vezes fica relegado a segundo plano em razão da economia processual) já que a decisão poderá tornar-se definitiva e a parte tem o direito de saber os limites de sua decisão e que requisitos foram preenchidos. ${ }^{72}$

\title{
5.4. Críticas ao sistema: necessidade de criação de mais uma técnica?
}

Muitas críticas podem ser proferidas quanto ao tema aqui em comento, mas surgem algumas questões. É necessária a criação de uma nova espécie de tutela que não irá transitar em julgado? Será que a ausência do trânsito em julgado não trará mais insegurança ao nosso sistema? E, por fim, por que não se outorgar o trânsito em julgado para esse tipo de tutela?

As técnicas já existentes, abordadas no segundo capítulo deste trabalho, já não são suficientes? O sistema processual brasileiro já admite o julgamento antecipado da lide em casos que versem somente sobre questão de direito. Além do mais, existem

71. José Carlos Barbosa Moreira, A motivação das decisões judiciais como garantia inerente ao estado de direito, in: Temas de direito processual, p. 118.

72. É semelhante o entendimento de Bedaque ao comentar a estabilidade da tutela antecipada em projeto de lei proposto pelo IBDP: “A exigência expressa quanto à fundamentação (art. $273, \S 4^{\circ}$ ), talvez desnecessária ante o disposto no art. 93, inciso IX, da Constituição Federal, revelase conveniente, visto que chama a atenção do julgador a respeito dessa garantia constitucional do processo. Mas é preciso enfatizar que motivar significa apresentar as razões porque se chegou a determinada conclusão. Não basta, evidentemente, a repetição de fórmulas vagas e imprecisas, vazias de qualquer conteúdo, como presentes ou ausentes os requisitos legais, verificada a ausência de perigo ou de prova inquívoca de verossimilhança. Essas afirmações expressam a conclusão do juiz, não os fundamentos pelos quais ele assim entende. Tem a parte o direito de saber por que os requisitos legais estão presentes ou ausentes" (José Roberto dos Santos Bedaque, op. cit., p. 332). 
diversos tipos de tutela que respondem de forma célere e eficaz aos pleitos dos cidadãos.

Toda essa problemática se resumem a determinados tipos de tutela diferenciada, não concernindo a todas as espécies. Isso porque não há controvérsia alguma quanto à conferência do trânsito em julgado nas ações possessórias, nas monitórias, nos mandados de segurança etc. A controvérsia reside nas seguintes espécies: 1) a tutela cautelar; 2) a tutela antecipada; 3) as tutelas autossatisfativas; 4) a tutela de evidência.

As tutelas cautelar, antecipada e autossatisfativas já existem no nosso sistema processual atual e são objetos de muitos estudos. Por outro lado, a tutela de evidência é uma das grandes novidades apontadas no projeto de CPC, e para a sua concessão não é necessária a urgência, apenas a evidência do direito e uma contestação não séria.

Esse instituto é claramente baseado no référé provision francês, cujos resultados apresentaos são satisfatórios. ${ }^{73}$ A Itália tentou adotar o sistema na reforma de seu processo societário - o que ficou conhecido como référé à la italiana - mas, ao contrário da experiência francesa, recebeu inúmeras críticas dos doutrinadores italianos e acabou sendo revogado.

Como no exemplo francês, o processo societário sumário italiano não tem como requisito a urgência, mas a evidência do direito. Igualmente, o contraditório é obrigatório, ou seja, o juiz apenas proferirá a ordinanza após ouvida a parte contrária e na ausência de contestação séria. Em algumas situações, quando se fala em procedimento sumário, logo vem à mente um procedimento desprovido de contraditório. No entanto, não é essa a hipótese prevista no ordenamento italiano, conforme o qual o conceito de procedimento sumário não está atrelado a uma ausência de contraditório, mas à superficialidade da cognição que culmina em uma decisão provisória, a qual, apesar de não adquirir força de coisa julgada, se estabiliza. ${ }^{74}$

Também como no référé provision, a decisão proferida no sistema societário italiano não adquire força de coisa julgada já que não é sentença, mas ocorre uma

73. É o que aponta Edoardo Ricci, Verso un nuovo processo civile?, Rivista di Diritto Processuale, Milano, vol. 58, n. 1, 2003, p. 211-226.

74. "La fase sommaria, che qui precede rendendo eventuale la cognizione ordinaria, è tale non per il difetto del contraddittorio (e, ripetiamo, la delega avrebbe consentito la costruzione di un modello di tipo monitorio), ma per la superficialità ed incompletezza della cognizione, cui corrispondene una decisione motivata come un'ordinanzza e non come una sentenza" (Bruno Capponi, Sul procedimento sommario di cognizione nelle controversie societarie, in: Bruno Cavallone; Edoardo Ricci; Achille Saletti (orgs.), Studi di diritto processual civile in onore di Giuseppe Tarzia, tomo II, p. 1654-1655). 
estabilização de fato, uma preclusão pro iudicato, chegando a se afirmar que ocorre uma coisa julgada formal. ${ }^{75}$

Uma parte da doutrina entende que a tutela se estabiliza e produz eficácia preclusiva extraprocessual e isso impediria a contestação acerca da existência da situação subjetiva substancial em um futuro juízo de mérito, especialmente de oposição à execução ou repetição de indébito. Por outro lado, Sérgio Menchini rebate essa posição ao afirmar que a ausência de força de coisa julgada não produz nenhuma eficácia preclusiva, podendo as partes discutir a questão posta nos autos em processo de cognição plena ${ }^{76}$ Mas o mesmo autor conclui que a autoridade da decisão não provém, necessariamente, da força da coisa julgada, mas da obrigação declarada pelo Judiciário e pelo título com força executiva. O fato é que o provimento resultará na intangibilidade da eficácia executiva, e poderá discutir apenas extrajudicialmente o mérito substancial da controvérsia.

Uma das principais críticas ao instituto do procedimento de cognição sumária é a suposta incompatibilidade com o art. $111^{77}$ da Constituição italiana. O comando constitucional prevê a garantia ao contraditório e, portanto, segundo a doutrina italiana estudada, um processo de cognição plena em que são analisados todos os argumentos

75. "Non vi è dubbio che, decorsi inutilmente i termini per l'appello, l'ordinanza esecutiva acquisti una stabilità di tipo processuale o formale; l'ampia lezione del comma 4 , che esclude qualsiasi impugnazione diversa dall'appello, comporta che avverso il provvedimento oramai stabile non risulteranno proponibili né altre impugnazioni ordinarie, né le impugnazioni straordinarie (nel che è ravvisabile, a mio sommesso avviso, qualche consistente profilo di incostituzionalità, soprattutto com riguardo all'opposizione di terzo). Non sapremmo se, nel caso, sai più corretto parlare di giudicato meramente formale (vale a dire di applicazione dell'art. 324 c.p.c. disgiunta dall'art. 2909 c.c)., ovvero di preclusione pro iudicato: sta di fatto che il provvedimento risulterà intangibile quanto all'efficacia esecutiva (ed anzi, addirittura più intangibile di una sentenza), mentre si potrà ridiscutere in qualsiasi altra sede, anche di autonomo accertamento negativo, il merito sostanziale della controversia" (idem, ibidem, p. 1669).

76. "La mancata realizzazione dell'autorità di cui all'art. 2.909 c.c. dovrebbe significare anche che al provvedimento de quo non si accompagna alcuna efficacia preclusiva, ossia che, in qualsivoglia processo a cognizione piena, entrambe le parti possono mettere in discussione il contenuto di esso: il creditore non è soggetto ad alcun vincolo circa l'ammontare del credito, potendo sostenere che questo è di importo superiore rispetto a cio che è stato stabilito con le vie sommarie, ed al debitore non è impedito di sollevare contestazioni in ordine all'esistenza del diritto (non si há, cioè, alcuna preclusione del dedotto e del deducibile), potendo, in particolare, far valere eventuali eccezioni o difese, pur preesistenti alla formazione del titolo, vuoi in sede di opposizione all'esecuzione, vuoi, con autônomo processo, anche di ripetizione dell'indebito, una volta che, spontaneamente oppure forzatamente, vi sai stato l'adempimento" (Sérgio Menchini, Nuove forme di tutela e nuovi modi di risoluzione delle controversie: verso Il superamento della necessita dell'accertamento com autorità di giudicato, Rivista di Diritto Processuale, ano LXI (seconda serie), n. 3, p. 877).

77. "Art. 111. La giurisdizione si attua mediante il giusto processo regolato dalla legge. Ogni processo si svolge nel contraddittorio tra le parti, in condizioni di parità, davanti a giudice terzo e imparziale. La legge ne assicura la ragionevole durata". 
das partes, produção de provas e, inclusive, assegurada uma sentença com força de coisa julgada.

O art. 19 do Decreto Legislativo n. 5 seria inconstitucional por ferir o art. 111 da Constituição, pois limitaria o direito à cognição plena. A doutrina italiana entende que essa norma dispõe sobre uma duração razoável do processo, o que não significa um processo extremamente rápido a ponto de suprimir a garantia constitucional do contraditório. Assim, a garantia da duração razoável do processo deve atuar ao lado das demais garantias constitucionais, e a duração de um processo não pode ser considerada desarrazoada se é para salvaguardar o direito de ação, a defesa das partes e o respeito à garantia do juiz natural e do contraditório. ${ }^{78}$

Soma-se a essas críticas o entendimento de Edoardo Ricci, para quem essa mera estabilização de nada adiantaria, pois criaria um título executivo sem força de trânsito em julgado o que, consequentemente, aumentaria o número de ações de cognição aprofundada. $^{79}$

As críticas ao instituto foram tantas, e a sua inaplicabilidade mínima, que na reforma processual de 2009 foram revogadas as disposições que diziam respeito ao

78. "Prima di concludere su questo punto occorre un'ultima precisazione. La norma costituzionale richiede che la durata del processo sai ragionevole, non breve. Per comprenderne l'esatto significato diviene allora indispensabile chiarire a cosa faccia riferimento, in questo caso, la Cost. richiamando il requisito della ragionevolezza, poiché si tratta di um concetto di grande rilievo nel campo del diritto costituzionale, ma di per sé non univoco. Nel caso di specie credo che ragionevole significhi, primariamente, compatibile con le altre garanzie costituzionali previste dallo stesso art. 111 e dagli artt. 24 e 25 cost. La duratta di un processo non può pertanto considerarsi irragionevole se le sue scansioni temporali sono dettate dalla necessita di salvaguardare il diritto di azione e di difesa delle parti, o il rispetto delle garanzie del giudice naturale, del contraddittorio e della terzietà e imarzialità dell'organo giudicante" (Andrea Graziosi, La cognizione sommaria del giudice civile nella prospettiva delle garanzie costituzinali, Rivista Trimestrale di Diritto e Procedura Civile, ano LXIII, n. 1, p. 137-174. No mesmo sentido, ver Sérgio Menchini, Nuove forme di tutela e nuovi modi di risoluzione delle controversie: verso Il superamento della necessita dell'accertamento com autorità di giudicato, Rivista di Diritto Processuale, ano LXI (seconda serie), n. 3, p. 869-902.

79 "È difficile comprendere, per quale ragione questo contenzioso dovrebbe essere, sul punto in esame, diverso da quello di diritto comune; e credo che debbano farsi avvertire anche qui le esigenze, di cui si dà carico la bozza elaborata dalla Comissione Vacarella. In altre parole, anche con riguardo al contenzioso societario e creditizio la presenza d'una autonoma giurisdizione contenziosa volta a creare un titolo esecutivo senza giudicato deve provocare un parallelo aumento dei poderi del giudice nell'ambito del processo di cognizione; anche in relazione a questo contenzioso il giudice del processo di cognizione deve poter pronunciare quei provvedimenti esecutivi, che possono essere ottenuti in separata sede con il procedimento sommario; ed anche qui tallì provvedimenti devono divenire idonei a definire la lite, in tutti i casi nei quali lo sono secondo il diritto comune. Da questo punto di vista il disegno di decreto legislativo delinea per il contenzioso societario e creditizio una giurisdizione meno efficace di quella di diritto comune, eh ha pertanto bisogno d'una integrazione" (Edoardo Ricci, Verso un nuovo processo civile?, Rivista di Diritto Processuale. p. 211-226). 
procedimento sumário, pela da Lei 69, de junho de 2009 com a introdução do art. 702bis no Codice di Procedura Civile.

$\mathrm{Na}$ primeira decisão da Corte de Cassação ${ }^{80}$ sobre a matéria, decidiu-se pela incompatibilidade do art. 19 do Decreto Legislativo n. 5 com as normas constitucionais que garantem o contraditório, principalmente, em razão da limitação à possibilidade de produção de prova em grau de apelo, conforme dispõe o art. 345 do código italiano. ${ }^{81}$

No entanto, apesar das inúmeras críticas ao processo societário italiano, entendemos que essa medida seria de grande valia se aplicada no Brasil. Aqui, ao contrário da Itália, não somos garantistas ao extremo e permitimos o julgamento antecipado das ações na hipótese em que o réu não dê continuidade ao processo. A possibilidade de estabilização da tutela diferenciada seria um avanço compatível com nosso sistema constitucional processual.

Além disso, como amplamente exposto, a outorga de força de coisa julgada a determinadas decisões é uma escolha legislativa, que entende que apenas algumas decisões poderiam ter essa força e que não está ligada a questões materiais ou a natureza da própria questão.

Dessa forma, cremos que o projeto do novo Código de Processo Civil poderia ter regulamentado a questão, como na proposta de lei já apresentada pelo IBDP, e dado força de coisa julgada a essas decisões. A simples estabilização endoprocessual das decisões judiciais não é suficiente, pois causaria estranheza aos operadores do direito que não estão acostumados com ela e não traria a segurança jurídica e definitividade que só a coisa julgada proporciona.

Assim, a mera estabilização, sem a outorga de coisa julgada, nos parece uma medida e uma solução muito tímida. Não adianta se basear em modelos de outros países: é necessário ter em mente qual a realidade brasileira. Principalmente se ponderarmos que o Brasil é um país de proporções gigantescas, com uma população

80. Corte di Cassazione, sez. I civ., sentenza 11 luglio 2008, n. 19238.

81. “Art. 345. Nel giudizio d'appello non possono proporsi domande nuove e, se proposte, debbono essere dichiarate inammissibili d'ufficio. Possono tuttavia domandarsi gli interessi, i frutti e gli accessori maturati dopo la sentenza impugnata, nonché il risarcimento dei danni sofferti dopo la sentenza stessa. Non possono proporsi nuove eccezioni, che non siano rilevabili anche d'ufficio. Non sono ammessi nuovi mezzi di prova e non possono essere prodotti nuovi documenti (1), salvo che il collegio non li ritenga indispensabili ai fini della decisione della causa ovvero che la parte dimostri di non aver potuto proporli o produrli nel giudizio di primo grado per causa ad essa non imputabile. Può sempre deferirsi il giuramento decisório". 
enorme e ainda muito desigual. Tal desigualdade faz com que muitos cidadãos brasileiros ainda não exerçam seu papel verdadeiro de cidadãos e não acessem o Poder Judiciário. Se, ainda com essa massa de cidadãos que sequer conhecem o Poder Judiciário, já temos problemas, que dirá quando nos tornarmos uma democracia real, com acesso de todas as pessoas à Justiça. A morosidade só aumentará, em oposição à satisfação da população.

É preciso tomar medidas corajosas. 


\section{PROPOSTAS LEGISLATIVAS}

\subsection{Panorama}

Para as ideias tratadas até aqui terem efetividade, seria necessário mudar em parte a legislação brasileira e prever essa modalidade de estabilização da decisão com ou sem a necessidade de outorga de coisa julgada às decisões judiciais. Essas decisões não necessariamente dependem de outorga da coisa julgada para que seus efeitos sejam sentidos fora do processo, mas não outorgar a coisa julgada para essas decisões nos parece uma medida tímida e que corre o risco de "não colar" no sistema brasileiro. De toda forma, para que elas possam estabilizar, ainda que só adquirindo uma preclusão pro iudicato (como acontece na Itália, na França e na Alemanha), deve haver uma parcial mudança legislativa, reconhecendo a força dessas decisões e estabelecendo prazos para que o réu apresente defesa ou recurso. Ou seja, é necessário conferir segurança a esse tipo de decisão para que os jurisdicionados e o próprio Poder Judiciário passem a utilizá-la.

Na sequência, serão estudadas algumas propostas de mudança legislativa que concernem exatamente ao tema. A primeira é a proposta apresentada pelo IBDP, encabeçada pela professora Ada Pellegrini Grinover, cujo escopo era dar estabilidade à decisão proferida em sede de tutela antecipada.

No projeto de novo Código de Processo Civil também há uma previsão de estabilização da decisão de cognição sumária, ${ }^{1}$ da tutela de urgência e da tutela antecipada. $^{2}$ A ideia desse dispositivo legal parte do mesmo pressuposto assumido quando do julgamento por revelia. A decisão liminar é proferida, em sede de cognição sumária, o réu é intimado a se manifestar e não apresenta manifestação: a decisão se estabiliza e o processo é extinto. ${ }^{3}$

As propostas e mudanças serão analisadas detidamente a seguir.

1. Tal possibilidade está prevista no art. 305 da última proposta apresentada pela Câmara dos Deputados: "Art. 305. A tutela antecipada satisfativa, concedida nos termos do art. 304, torna-se estável se da decisão que a conceder não for interposto o respectivo recurso" (Anexo II).

2. Na realidade, o título do livro do projeto de Código de Processo Civil chama-se da tutela antecipada; como espécies, aparecem a tutela de urgência e a tutela de evidência. $\mathrm{O}$ art. 305 está previsto especificamente para as tutelas de urgência e, prima facie, não se aplicaria às tutelas de evidência.

3. "§ $1^{\circ}$ No caso previsto no caput, o processo será extinto" (Anexo II). 


\subsection{Proposta de estabilização apresentada pelo Instituto Brasileiro de Direito Processual}

A primeira proposta legal que previu a estabilização da tutela diferenciada foi coordenada pela professora Ada Pellegrini Grinover e acompanhada por estudiosos do processo civil brasileiro, com o apoio do IBDP. Nela havia a previsão de estabilização da decisão da tutela antecipada, tornando "definitivo e suficiente o comando estabelecido por ocasião da decisão antecipatória". ${ }^{4}$

A proposta assumida pelo IBDP muda substancialmente o conceito de tutela antecipada, uma vez que essa decisão não teria mais caráter instrumental, mas definitivo, podendo se imutabilizar com o trânsito em julgado da decisão. ${ }^{5}$ Dessa forma, teria de se deslocar a própria natureza da tutela antecipada de instrumental e provisória para se tornar uma decisão de natureza autônoma. ${ }^{6}$

Com essa mudança da natureza estrutural do instituto, deve-se analisar se a instrumentalidade e a provisoriedade são inerentes a ele, e se a conclusão for positiva, a mudança legislativa se mostra inviável. Por outro lado, se for constatado que nem a instrumentalidade nem provisoriedade são elementos essenciais ao instituto, a mudança é viável podendo ser aplicada.

Analisaremos a instrumentalidade sob dois enfoques: o funcional e estrutural. ${ }^{7}$

No plano funcional, qual seria a função da tutela sumária? Verificamos que a sua função é dar suporte à tutela de cognição plena que será proferida ao longo do processo de conhecimento, seja pelo perigo de perecimento do direito (por exemplo, no caso da antecipação da produção probatória), seja pela urgência no pedido requerido pelo autor (como na hipótese de negativa de um plano de saúde de cobrir uma cirurgia de urgência). Daí é possível chegar à seguinte conclusão: no plano funcional as tutelas diferenciadas urgentes somente servem a um processo principal porque assim escolheu o legislador pátrio, não em razão da sua natureza.

4. Ada Pellegrini Grinover. Tutela jurisdicional diferenciada: a antecipação e sua estabilização, in: O processo: estudos e pareceres, p. 108. No Anexo I consta a íntegra da proposta de lei apresentada à época.

5. José Roberto dos Santos Bedaque, Tutela cautelar e tutela antecipada: tutelas sumárias e de urgência (tentativa de sistematização), p. 331.

6. A mudança da natureza da tutela antecipada também foi reconhecida por José Roberto dos Santos Bedaque, para quem a tutela antecipada passaria a assumir uma "condição de tutela sumária não urgente" (idem, ibidem, p. 333).

7. Essa análise foi muito bem feita por Alex Costa Pereira, Tutela sumára: a estabilização da tutela antecipada e sua adequação ao modelo constitucional do processo civil brasileiro, p. 92. 
Já do plano estrutural, a tutela sumária somente é dependente porque a legislação assim a obriga. É o caso da tutela cautelar em que se perde eficácia se não for proposta a ação no prazo de trinta dias subsequentes ao cumprimento da liminar. Na tutela antecipada ocorre fenômeno semelhante, pois, como geralmente esta é proferida em processo ordinário de cognição plena, a decisão liminar é estruturalmente dependente da sentença que será proferida no final do processo.

A estrutura dessas duas decisões são dependentes da decisão de cognição plena por um simples motivo: escolha legislativa.

Alex Costa Pereira afirma que existem três "portas" para que a decisão de cognição sumária seja alçada a uma decisão definitiva e adquira força de coisa julgada. As duas primeiras estão relacionadas à instrução probatória, ao ônus probatório e a ampla defesa, em que somente um processo de cognição ordinária é capaz de proporcionar às partes a segurança jurídica máxima de que as questões levadas à juízo serão analisadas profundamente, intimando-as para se manifestarem. A terceira “porta” é a estabilização prevista no projeto de lei do IBDP, ou seja, a estabilização da tutela antecipada diante da inércia do réu em instaurar um processo de cognição ordinária, recorrer ou apresentar defesa. ${ }^{8}$

Essa hipótese já é permitida na nossa legislação com base no art. 330 do CPC, quando do julgamento antecipado da lide por ausência de impugnação específicados fatos alegados na inicial e também por revelia. O julgamento por revelia ou em razão da ausência de impugnação específica é um confissão ficta em que se admite que o réu confessou ficticiamente os fatos narrados na inicial. Trata-se de confissão ficta pois o

8. "Mas há uma terceira porta, da qual lança mão o legislador em situações específicas, e até agora excepcionais, quando urge, no processo, uma solução rápida e definitiva dotada de efetividade, utilidade e com economia de juízo. É a técnica processual de transformação da verossimilhana em juízo de verdade por meio da aplicação da regra da ausência de impulso processual de atividade de interesse da parte e sob o princípio da demanda. Orienta-se pela premissa de que as garantias da ampla defesa e do contraditório, assim como a realização do devido processo legal, são asseguradas não só pela materialização efetiva no processo dos atos procedimentais predeterminados pelo legislador, mas também, e em paridade de gradução, quando se constata que à parte que se sujeita à decisao de verossimilhança foi franqueada - mas não promovida - a instauração do processo de cognição plena e exauriente. Mostrando-se a parte inerte em relação ao exercício de direito lhe conferido pela norma processual, considera-se extinta a faculdade da parte de contrariar fato e atuar ativamente na comprovação do histórico que precedeu a propositura da demanda, pelo transcurso do tempo informativo do impulso processual que caberia ao interessado. Dispensam-se, assim, os ordinários métodos de transformação legal da verossimilhança em juízo da verdade - via produção de provas ou regra de sua distribuição - e sua correlata função demonstrativa dos fatos alegados, elevando, ainda que não substancialmente as para os fins instrínsecos ao processo, os fatos apresentados pelo demandante da condião de erossímeis à de legalmente verdadeiros" (idem, ibidem, p. 113-114). 
réu não adotou essa postura, mas, como manteve-se inerte (ou não apresentou uma contestação séria), é como se tivesse confessado.

Mas é interessante notar que o procedimento proposto somente se verifica em caso de inércia do réu, caso esse não proponha o procedimento principal no prazo estabelecido legalmente. Trata-se de solução semelhante ao que ocorre nos julgamentos por revelia já previstos na legislação atual. Se a decisão antecipatória ocorrer no curso do processo e nenhuma das partes requerer o prosseguimento da ação, esta poderá transitar em julgado no prazo de trinta dias.

Trata-se de solução ousada, não há dúvida. Mas o sistema já prevê algo semelhante com o julgamento por revelia. Em sistemas estrangeiros a decisão não adquire força de coisa julgada, apesar de precluírem, apenas se estabilizam. Caso tivesse sido acolhida a proposta legal da não obrigatoriedade de continuidade do processo em caso de silêncio do réu, a própria natureza da tutela antecipada mudaria. Deixaria de ser instrumental para tornar-se independente, e também não seria mais provisória, passando a ser definitiva. ${ }^{9}$ Alex Costa Pereira aborda especificamente esse assunto, bem como a escolha do legislador de transformar os fatos verossimilhantes em juízo de verdade:

\begin{abstract}
A transformação jurídica da verossimilhança em verdade legal no processo, que na generalidade dos casos decorre do exaurimento da função demonstrativa das provas acerca dos fatos apresentados pelas partes e aplicação de regra de distribuiçção do dever de comprovação, passa a ser implementada também mediante omissão da parte no exercício de faculdade processual que lhe é assegurada por estrito cumprimento das garantias constitucionais de segurança que tutelam o processo civil brasileiro. Em outras palavras, ante a ausência de impulso processual de iniciativa exclusiva da parte interessada na atividade demonstrativa da prova e no exercício pleno da ampla defesa e do contraditório, é admitida a declaração e definição da vontade concreta da lei por provimento judicial amparado em juízo de verossimilhança e probabilidade. ${ }^{10}$
\end{abstract}

Quando o réu fica inerte e não dá continuidade ao processo de cognição plena e exauriente, instaurando o procedimento respectivo, ocorre a preclusão endoprocessual da decisão diferenciada prolatada no início do processo. Nesse momento, essa decisão de cognição sumária passaria a produzir efeitos de coisa julgada, assumindo a natureza de sentença liminar e podendo sujeitar-se à coisa julgada (pois, reiteramos, a outorga

9. Idem, ibidem, p. 120.

10. Idem, ibidem, p. 118. 
de coisa julgada é questão de escolha legislativa). O risco que se coloca aqui é o da violação ao contraditório, ${ }^{11}$ o qual, contudo, está assegurado na proposta formulada. A possibilidade de se recorrer da decisão ou mesmo dar continuidade ao processo e propor o processo cognitivo principal parece garanti-lo.

A novidade proposta por esse projeto é de que essa decisão de cognição sumária, se estabilizaria, sem a necessidade do processo de cognição aprofundada. Muitos criticaram-na por conferir trânsito em julgado às decisões judiciais e não apenas oferecer a estabilização endoprocessual que existe nos outros ordenamentos. Contudo, em que pese o respeito a essa posição doutrinária, ela não se sustenta. Qual a diferença desse provimento com o julgamento por revelia ou com o julgamento antecipado? Nenhuma. Nas primeira hipótese, o réu não manifestou interesse em recorrer da decisão ou apresentar qualquer tipo de impugnação, mas se conformou com a decisão judicial. $^{12}$

É importante ressaltar que essa hipótese legal somente aplicar-se-ia aos casos de direitos disponíveis. Ou seja, se o réu não recorreu é porque conformou-se com a decisão, e, por se tratar de questão de direito disponível, não cabe ao Estado tutelar as partes como se fossem questões de interesse público. Caso o réu entenda que é melhor não prosseguir com a demanda, ele não o fará.

Do ponto de vista sociológico, a proposta inicialmente apresentada pelo IBDP também se sustentava, ao ensejar paz social de forma célere às partes. ${ }^{13}$ Além disso,

11. Risco esse levantado por José Roberto dos Santos Bedaque (op. cit., p. 334).

12. “As tutelas sumárias caracteriza-se por ser precedidas de cognição não exauriente. É elemento comum a todas elas, cuja função é impedir que o tempo de duração do processo possa comprometer sua efetividade. É a eterna luta do sistema processual contra o tempo. Acontece que o legislador pode, discricionariamente, optar por soluções diversas quanto à eficácia da tutela sumária com conteúdo satisfativo. Existem decisões dessa natureza que acabam representando a solução definitiva do conflito de interesses, quer porque as partes conformam-se com o resultado e não provocam a atividade cognitiva plena, quer porque o julgamento, embora sumária a cognição, adquire a qualidade da coisa julgada. Têm eficácia idêntica à produzida pela tutela de cognição plena" (José Roberto dos Santos Bedaque, Estabilização das tutelas de urgência, in: Mauricio Zanoide de Moraes; Flávio Luiz Yarshell (orgs.), Estudos em homenagem à professora Ada Pellegrini Grinover, p. 664).

13. “Também sob o aspecto sociológico, a técnica de equiparação entre a execução do juízo cognitivo completo e a livre renúncia pela parte detentora do interesse em realizá-la corresponde também ao senso comum de justiça do método da prestação jurisdicional pelo Estado. A demonstração da ciência inequívoca da parte contra a qual recai o provimento sumário potencialmente definidor do litício, em todos os seus termos e consequências, é suficiente se assegurar a plena fruição de todas as garantias constitucionais de segurança ao cidadão que tutelam o processo civil brasileiro e validar a relação jurídica processual triangular a partir dela instaurada. O demandado que entenda ter razão na controvérsia levada à solução judicial certamente não se calará ou se conformará com uma decisão sumária que lhe seja desfavorável, não se podendo ainda ignorar o fato de que 
como ressaltamos diversas vezes, cabe à parte interessada (no projeto legal, o réu) impulsionar o processo e desenvolvê-lo de acordo com seus interesses, instaurando um juízo de cognição plena e exauriente. Em nada frustrava, portanto, as garantias processuais ou o interesse do réu, uma vez que tais exigências têm como fonte o princípio da demanda, pelo qual a escolha de agir ou não agir cabe ao sujeito processual e não ao Estado. ${ }^{14}$

Na justificativa do projeto, Ada Pellegrini Grinover assevera a possibilidade da estabilização dessa tutela, por se tratar de direito disponível e ser da conveniência das partes a análise pela continuidade ou não do processo nos termos tradicionais, com ampla instrução probatória. Em geral, a decisão cautelar basta e o réu se conforma diante do direito evidente do autor e da pequena possibilidade de reversibilidade da decisão. ${ }^{15}$

A grande inovação da professora Ada, que muitas vezes é criticada, é a imposição de coisa julgada para esse tipo de decisão. Como expusemos, a coisa julgada depende de escolha legislativa, e não haveria nenhum problema em se outorgar força julgada a esse tipo de decisão, evitando, assim, qualquer discussão sobre a força e a estabilidade dessa decisão. ${ }^{16}$ Dessa forma, a decisão de cognição sumária poderia adquirir força de

eventuais prejuízos decorrentes desse provimento à própria provisoriedade da decisão, seja ela obrigatória ou eventual" (Alex Costa Pereira, op. cit., p. 118).

14. "O impulso processual que cabe à parte na realização e desenvolvimento de atividade processual de seu interesse, quando relacionado à instauração do juízo de cognição plena e exauriente, tem suas raízes sedimentadas no princípio da demanda, ou seja, na própria busca e alcance da atividade jurisdicional. Mas esse impulso processual também se manifesta sob os auspícios do princípio dispositivo, que atua quando a demanda em procedimento ordinário de cognição já está em curso, podendo a parte dispor da causa instaurada, seja deixando de alegar ou provar fatos defensivos de seu eventual direito subjetivo, seja ainda demonstrando desinteresse pelo exaurimento completo das instâncias jurisdicionais previstas no organograma do judiciário ao qual está submetida" (Alex Costa Pereira, op. cit., p. 132).

15. Como advogada de empresas do ramo da construção civil já me deparei com situações assim, em que a construtora e a incorporadora já estão efetuando reparos de vícios construtivos na obra, mas o condomínio ajuíza uma ação, pois um item corre sério risco de desabar e põe a vida dos condôminos em perigo. É dada a tutela antecipada e, dependendo da evidência do direito do autor, a construtora e incorporadora não agravam, se conformam com a decisão.

16. A justificativa apresentada pela professora Ada Pellegrini Grinover merece ser transcrita: "A proposta de estabilização da tutela antecipada procura, em síntese, tornar definitivo e suficiente o comando estabelecido por ocasião da decisão antecipatória. Não importa se se trata de antecipação total ou parcial. O que se pretende, por razões eminentemente pragmáticas - mas não destituídas de embasamento teórico -, é deixar que as prórpias partes decidam sobre a conveniência, ou não, da instauração dou do prosseguimento da demanda e sua definição em termos tradicionais, com atividades instrutórias das partes e cognição plena e exauriente do juiz, com a correspondente sentença de mérito. Se o ponto definido na decisão anteciaptóra é o que as partes efetivamente pretendiam e deixam isto claro por meio de atitude omissiva consistente em não propor a ação de conhecimento (em se tratando de antecipação em procedimento antecedente) ou em não requerer o prosseguimento da ação (quando a antecipação é concedida no curso do processo de 
coisa julgada caso o réu não manifestasse interesse em continuar o processo, com a propositura da ação de cognição plena ou mesmo diante da ausência de contestação.

Vimos que o procedimento previsto no projeto legal possibilitaria o pleno exercício do contraditório e da ampla defesa. A decisão proferida nesse procedimento teria idoneidade para representar a resposta final do Estado à pretensão do autor e, portanto, a decisão teria a possibilidade de transitar em julgado. $O$ silêncio no processo civil, principalmente em casos de direitos disponíveis, deve ser entendido como a aquiescência do réu para a decisão prolatada e, consequentemente, deve permitir o julgamento da demanda.

$\mathrm{Na}$ hipótese da proposta, se fosse concedida a liminar, qualquer uma das partes poderia ajuizar a ação de cognição plena e exauriente para a continuidade do processo. No entanto, se não houvesse a referida ação, a decisão transitaria em julgado. Se a antecipação ocorresse durante o processamento da ação, qualquer uma das partes poderia requerer a continuidade do processo no prazo de trinta dias, com o intuito de ver julgado o mérito da ação. Do contrário, a decisão transitaria em julgado.

Bedaque, apesar de ser um dos coautores do projeto, critica a proposta em alguma medida, ao afirmar que a solução seria ousada pois não é dada a mesma solução em outros ordenamentos jurídicos. ${ }^{17}$ Para evitar o prosseguimento do processo na proposta de lei, haveria a dispensa do pagamento de custas e honorários de sucumbência caso o réu não prossiga com a ação, sendo claramente uma forma de evitar a continuidade do processo.

conhecimento, tem-se por solucionado o conflito existente entre as partes, ficando coberta pela coisa julgada a decisão proferida. [...] Preferimos a solução da coisa julgada, por várias razões: a) por sua maior estabilidade. B) porque a eficácia executiva pode ser interpretada como adequada apenas à antecipação dos efeitos da sentença condenatória; e c) para que se guarde simetria com o já tradicional instituo do julgamento antecipado da lide, cabível em caso de revelia" (Ada Pellegrini Grinover apud José Roberto dos Santos Bedaque, Estabilização das tutelas de urgência, in: Mauricio Zanoide de Moraes; Flávio Luiz Yarshell (orgs.), op. cit., p. 662).

17. Apesar do receio do referido professor, haja vista que pode ferir as garantias constitucionais de defesa das partes, Bedaque afirma que "a solução apresentada não difere substancialmente do julgamento à revelia previsto no art. 330, I, do Código de Processo Civil. Em ambos os casos, devido à omissão do réu, o autor obtém resultado favorável mediante decisão precedida de cognição sumária e apta a se tornar definitiva" (José Roberto dos Santos Bedaque, Estabilização das tutelas de urgência, in: Mauricio Zanoide de Moraes; Flávio Luiz Yarshell (orgs.), op. cit., p. 669). 


\subsection{Projeto do novo Código de Processo Civil}

Em 2009, o Senado designou uma comissão de juristas que elaborou um anteprojeto de novo Código de Processo Civil - em tempo recorde, diga-se de passagem. Submetido, em aproximadamente seis meses o Projeto de Lei n. 166, de 2010, foi aprovado pelo plenário do Senado, encabeçado pelo senador Valter Pereira e, então, seguiu à Câmara dos Deputados para votação, onde permanece até o fechamento deste trabalho, em dezembro de 2013.

O projeto encaminhado à Câmara manteve na essência alguns pontos importantes: foram preservadas as ideias de dar maior celeridade ao processo, prestígio de precedentes, simplificação do procedimento, tratamento isonômico de situações semelhantes, entre outros. No entanto, outros aspectos foram brutalmente modificados na Câmara, ocorrendo inclusive a confusão de termos técnicos e criando-se situações complicadas que hoje não mais se justificam.

Um dos avanços do projeto é tratar as medidas cautelares e antecipatórias dentro do mesmo capítulo, uma vez que elas são tutelas de urgência de cognição sumária. ${ }^{18}$ A tutela de urgência é gênero, enquanto tutelas cautelares e antecipadas são suas espécies. Elas podem também ser denominadas tutelas sumárias urgentes, haja vista que o requisito da urgência é essencial para o deferimento da tutela. Assim, intitular o Livro V do novo código "Da tutela antecipada" nos parece um erro.

O correto seria falar das tutelas urgentes e da tutela de evidência. O art. 295 do projeto assim dispõe: “A tutela antecipada, de natureza satisfativa ou cautelar, pode ser concedida em caráter antecedente ou incidental. Parágrafo único. A tutela antecipada pode fundamentar-se em urgência ou evidência”. Ou seja, o legislador reconheceu que existem tutelas urgentes e satisfativas que não necessitam da continuidade do processo ordinário, pois elas por si mesmas bastam e satisfazem a parte.

Foi introduzido no anteprojeto e mantido pela Câmara o conceito de tutela de evidência. Demonstramos que a tutela de evidência também é uma tutela de cognição

18. Ricardo de Barros Leonel, Tutela jurisdicional diferenciada no projeto de novo Código de Processo Civil. No mesmo sentido é o entendimento de Eduardo Talamini ao analisar o projeto de lei, Tutela de urgência no projeto de Novo Código de Processo Civil: a estabilização da medida de urgência e a 'monitorização' do processo civil brasileiro, Revista de Processo, ano 37, n. 209, julho 2012. 
sumária, em que o juiz analisa somente os fatos levados a juízo pelo autor. Ao contrário da tutela antecipada e cautelar, a tutela de evidência não tem o requisito da urgência, e é deferida apenas quando a probabilidade de êxito do autor é extremamente grande, pois seu direito é evidente.

No caso das tutelas de urgência, é vista com bons olhos a sua unificação a partir da tutela antecipada e da tutela cautelar. Pois, apesar de cada uma das espécies de tutela de urgência ter requisitos específicos, elas pretendem acautelar uma situação de urgência, em que o direito da parte pode perecer e o seu objetivo é evitar esse perecimento, resguardando, assim, uma garantia de utilidade do processo.

O ponto alto do projeto de lei do CPC é a previsão da estabilização das tutelas de urgência. Ilustrativa desse avanço e em consonância com sistemas estrangeiros já analisados é a possibilidade da estabilização endoprocessual, sem formação de coisa julgada. Para afastar os efeitos dessa estabilidade, entretanto, seria necessário ajuizar uma ação autônoma. Essa é a redação do art. 293 do projeto:

A decisão que concede a tutela não fará coisa julgada, mas a estabilidade dos respectivos efeitos só será afastada por decisão que a revogar, mas a estabilidade dos respectivos efeitos só será afastada por decisão que a revogar, proferida em ação ajuizada por uma das partes.

Nesse dispositivo legal, ficam claros alguns pontos que já abordamos. O primeiro deles é a possibilidade de estabilização sem necessarimente outorgar a força de coisa julgada, que nada mais é que uma escolha legislativa. A decisão, embora não tenha força de coisa julgada, terá seus efeitos. Para afastá-la, será necessário ajuizar uma ação específica.

Ainda no referido projeto de lei, essas mesmas decisões, caso não haja defesa ou qualquer tipo de impugnação, irão se estabilizar, deixando de ter uma natureza meramente instrumental e provisória para tornar-se uma decisão definitiva. Ou seja, a decisão continuará produzindo efeitos independentemente de propositura de uma ação ordinária ou de formulação de um pedido final pelo autor.

Redação semelhante foi mantida pela Câmara no art. 305 e respectivos parágrafos:

Art. 305. A tutela antecipada satisfativa, concedida nos termos do art. 304, torna-se estável se da decisão que a conceder não for interposto o respectivo recurso.

$\S 1^{\circ}$ No caso previsto no caput, o processo será extinto. 
$\S 2^{\circ}$ Qualquer das partes poderá demandar a outra com o intuito de rever, reformar ou invalidar a tutela antecipada satisfativa estabilizada nos termos do caput.

$\S 3^{\circ}$ A tutela antecipada satisfativa conservará seus efeitos, enquanto não revista, reformada ou invalidada por decisão de mérito proferida na ação de que trata o $\S 2^{\circ}$.

$\S 4^{\circ}$ Qualquer das partes poderá requerer o desarquivamento dos autos em que foi concedida a medida, para instruir a petição inicial da ação a que se refere o $\S 2^{\circ}$, prevento o juízo em que a tutela satisfativa foi concedida.

$\S 5^{\circ} \mathrm{O}$ direito de rever, reformar ou invalidar a tutela antecipada, previsto no $\S 2^{\circ}$ deste artigo, extingue-se após dois anos, contados da ciência da decisão que extinguiu o processo, nos termos do $\S 1^{\circ}$.

Essa técnica é claramente baseada no référé provision francês, em que se espera que a parte irá se conformar com a decisão proferida e que, em muitas situações, diante da evidência do direito do autor, o demandado se conformará com a decisão proferida, não lhe apresentando recursos ou impugnando. Com o conformismo do réu, o autor já teria atingido a sua finalidade e, assim, não seria necessária a propositura de uma ação com pedido amplo. ${ }^{19}$

Nessa última versão apresentada pela Câmara, fala-se também na estabilização da decisão e que a eventual reforma caberia ao réu, tal como previsto nos sistemas italiano e francês. Como se trata de hipótese de direito dispositivo, se o réu não apresentar recurso é plenamente possível a possibilidade de estabilização da decisão. No entanto, temos algumas críticas a essa redação.

Em primeiro lugar, o prazo para a propositura da ação prevista no $\S 2^{\circ}$ do art. 305 é muito longo. Deveria ser um prazo de trinta dias, como é para a propositura da ação principal no nosso sistema atual, no capítulo de cautelar. Isso porque não existe a chance de o réu não ficar sabendo da concessão da tutela antecipada, já que ele deverá ser intimado para o cumprimento da decisão. Não há qualquer risco de o réu não ser citado e sofrer algum prejuízo, e a oportunidade de defesa é dada.

19. Nesse sentido, Ricardo de Barros Leonel fala em uma aposta do legislador: "A técnica da estabilização da tutela de urgência trabalha com probabilidades e riscos. A probabilidade na qual o legislador investe é de que em muitos casos não haverá resistência por parte do demandado, que se conformará e cumprirá a medida deferida liminarmente. Dessa forma, a utilidade prática pretendida pelo autor já terá sido alcançada, tornando-se desnecessária a propositura de ação 'principal', de conhecimento, e o exame do seu mérito, nada obstante não se forme coisa julgada com relação ao provimento judicial que concedeu a medida urgente" (idem, ibidem). Talamini fala em monitorização do processo, para referido autor o projeto acabou utilizando da mesma técnica do processo monitório ao prever a possibilidade de formação de um título executivo, sem a necessidade de coisa julgada. Com a formação desse título, caberá ao réu a propositura de ação própria, de cognição exauriente, para desconstituir referido título. (idem, ibidem). 
Além disso, o caput do artigo e o $\S 1^{\circ}$ parecem incompatíveis com o $\S 2^{\circ}$ e o $\S 3^{\circ}$. $\mathrm{O} \S 1^{\circ}$ é claro ao asseverar que o processo será extinto caso não seja interposto recurso pelo réu contra a decisão que concedeu a tutela antecipada satisfativa. Em seguida, o $\S 2^{\circ}$ e o $\S 3^{\circ}$ estabelecem a possibilidade de propositura de ação a qualquer tempo, no prazo de dois anos, conservando assim a decisão os seus efeitos. Mas, como pode o processo ser extinto e ainda aguardar a propositura de eventual ação judicial? Caso não seja proposta nem a ação prevista no $\S 2^{\circ}$ nem interposto recurso contra a decisão, o processo é extinto, mas conservaria a eficácia da decisão?

Por fim, em nenhum momento o dispositivo legal enseja a possibilidade de conferir força de coisa julgada à decisão, nem de preclusão endoprocessual, referindose simplesmente à estabilidade da decisão. No entanto, o $\S 5^{\circ}$ dispõe que "o direito de rever, reformar ou invalidar a tutela antecipada, previsto no $\S 2^{\circ}$ deste artigo, extingue-se após dois anos, contados da ciência da decisão que extinguiu o processo, nos termos do $\S 1^{\circ}$ ".

Ora, o legislador claramente inspirou-se no prazo atual para a propositura da ação rescisória. Fica evidente com a leitura do dispositivo que, apesar de o legislador não ter outorgado força de coisa julgada a essas decisões, sua natureza é de sentença a que poderia ser outorgada força de coisa julgada. Além disso, o prazo é por demais prolongado, haja vista a atual facilidade em se obter informações.

Por fim, o legislador também perdeu a oportunidade de estender a possibilidade de estabilização para as hipóteses de tutela de evidência.

Por todas essas razões entendemos que o projeto de Código de Processo Civil deve ser analisado com maior calma, submetido novamente à comissão de juristas que usará os termos técnicos adequados e, finalmente, deverá ser submetido a uma audiência pública para consulta da população. Um código não se faz às pressas, sob pressão política, é necessário amadurecimento, discussão e análise dos verdadeiros problemas para se avançar.

Ainda, é necessário avançar, com a introdução de institutos novos e novas técnicas. Por esse motivo que defendemos que o legislador foi tímido ao prever simplesmente a estabilização da tutela de urgência e evidência quando poderia ter ido além, ter conferido força de coisa julgada e dado maior segurança jurídica às partes e efetividade à decisão. 


\section{CONCLUSÃO}

O objetivo deste trabalho, como definido na introdução, é analisar a tutela jurisdicional diferenciada e utilizá-la como um dos métodos para a solução do problema da morosidade do Poder Judiciário.

Para tanto, examinamos o conceito de tutela jurisdicional, passando de sua evolução histórica, que se confunde em parte com a própria história da ciência do Direito Processual, para chegar ao conceito atual de tutela jurisdicional. Uma tutela que não é apenas a garantia de acesso ao Poder Judiciário, mas uma tutela efetiva, a própria entrega do bem da vida, exigindo uma atuação pró-ativa do juiz e a colaboração das partes.

Utilizando esse desenvolvimento histórico e conceitual da tutela jurisdicional, partimos para o estudo dos diversos tipos de tutela jurisdicional diferenciada, cuja principal característica, utilizando o conceito de Proto Pisani, é a sumariedade na cognição.

Com isso, analisamos as tutelas de urgência (tutela cautelar e tutela antecipada), as tutelas diferenciadas não urgentes (tutela de evidência e outros procedimentos de cognição sumária). Como exposto, ao longo do capítulo 2 a grande problemática da estabilização da tutela jurisdicional diferenciada reside na tutela cautelar, antecipada e de evidência, isso porque, a rigor, são decisões provisórias que deverão ser confirmadas ao longo de um processo de cognição plena e exauriente.

No capítulo 2 explicamos minuciosamente cada uma das características desses tipos de tutelas, a provisoriedade da decisão cautelar e da tutela antecipada, o requisito da urgência para o deferimento do pedido e a necessidade de continuidade do processo, com a investigação plena dos fatos. Na tutela de evidência analisamos legislação de outros países, como a França com o seu référé provision, a obra do Ministro Luiz Fux que trata sobre o tema e o projeto de código de processo civil que prevê esse novo tipo. Por fim, examinamos outros tipos de tutela jurisidiconal diferenciada, mas que não apresentam grandes dificuldades quanto ao tema da estabilização, haja vista que já é previsto em lei a possibilidade de outorga de força de coisa julgada para as decisões desses tipos processuais. 
Após, passamos a pesquisar sobre o próprio conceito de tutela jurisdicional diferenciada utilizado no Brasil e em outros ordenamentos jurídicos e também sobre cada uma das características específicas da tutela jurisdicional diferenciada, passando pela tipicidade, limitação da cognição e a celeridade. Em cada um desses tópicos desenvolvemos a importância da tipicidade da tutela jurisdicional diferenciada, como um meio para garantia dos princípios constitucionais-processuais. A tipicidade processual in casu é importante, já que descreve o procedimento que será utilizado pelas partes. Por não se tratar de procedimento ordinário, é necessário que as partes saibam cada um dos passos desse novo procedimento, é importante que o Estado, através do Poder Judiciário, guie as partes pelos caminhos corretos a serem perseguidos, pois somente dessa forma não haverá qualquer violação à garantias constitucionais.

Tratamos ainda da limitação da cognição e fizemos uma diferenciação entre a sumarização da atividade cognitiva do juiz e da sumarização do procedimento. Esses dois tipos não se confundem, são coisas totalmente diferentes. A sumarização da atividade cognitiva é a pedra angular da tutela jurisdicional diferenciada, é o corte feito pelas partes, ao levar somente uma parte da discussão ao Poder Judiciário (como é o caso da tutela cautelar e antecipada), ou mesmo a limitação imposta pelo próprio legislador, ao determinar que naquele procedimento específico somente poderão ser tratados determinados assuntos e não haverá cognição profunda e investigação completa dos fatos (como é o caso do mandado de segurança, ações, possessórias, consignação em pagamento). Por outro lado, a sumarização do procedimento não necessariamente se confunde com a sumariedade na cognição. Podemos ter procedimentos sumários (como exemplo, o sumaríssimo da Lei 9.099/1995) que possuem cognição plena e exauriente e, portanto, não são considerados como tutela jurisdicional diferenciada. No entanto, como exposto no capítulo 3.2.1 a tipicidade é um dos elementos mais importantes na tutela diferenciada, assim, alguns procedimentos especiais podem prever a possibilidade de cognição sumária e terem um procedimento sumarizado (no sentido de menos fases e mais simplificado), mas não necessarimente todo procedimento sumarizado terá cognição sumária.

No capítulo 4 investigamos sobre os princípios constitucionais-processuais sob a ótica da estabilização da tutela diferenciada. Esse capítulo é importantíssimo, pois nele demonstramos minuciosamente que é possível conciliar todos os princípios 
constitucionais como o devido processo legal com a duração razoável do processo. Nesse capítulo mostramos técnicas utilizadas em outros países para chegar a esse delicado equilíbrio, também analisamos o momento histórico em que estamos inseridos e qual deve prevalecer em um eventual embate. O processo ordinário, de cognição plena e exauriente, não é mais adequado para a nova realidade social que exige uma resposta rápida e efetiva do Poder Judiciário. Então, de um lado supostamente temos o princípio da igualdade e do devido processo legal, de outro lado temos a eficiência e a duração razoável do processo. Analisando profundamente o tema vemos que esse "duelo" entre princípios não existe. O tratamento igualitário entre as partes sempre deve ser o rumo a ser seguido, o devido processo legal também nunca poderá ser desrespeitado, o que acontece na realidade é uma mitigação desses dois princípios para que eles se equilibrem com a eficiência e a duração razoável do processo. Como mostrado, não necessariamente um processo longo e com a investigação profunda dos fatos levará a uma decisão justa. É necessário equilíbrio.

Após analisamos a pragmática processual sob a ótica da estabilização da tutela diferenciada. Examinamos atentamente a problemática da outorga da coisa julgada a esse tipo de decisão, passando por doutrinadores que enxergam somente a possibilidade de o processo de cognição ordinária poder formar coisa julgada e chegamos à conclusão de que, na realidade, a possibilidade de transitar em julgado uma decisão é uma escolha legislativa e que, respeitado o devido processo legal, não haveria problema algum em outorgar força de coisa julgada a esse tipo de decisão; principalmente porque o nosso sistema processual prevê o julgamento por revelia. Em síntese, não haveria grande diferença entre o julgamento por revelia e a possibilidade de outorgar força de coisa julgada para as decisões proferidas de forma provisória, desde que dada a oportunidade de defesa.

Avaliamos ainda alguns aspectos importantes, como a questão da sucumbência e a fundamentação da decisão. Defendemos que a não fixação de sucumbência para o réu que concordar com o pedido do autor poderia servir como um estímulo a não dar continuidade a processos que estão fadados ao insucesso. A fundamentação da decisão também foi uma questão por nós trabalhada, apesar de estar previsto constitucionalmente, é sempre bom relembrar desse princípio e da sua importância.

Por fim, analisamos criticamente propostas de lei já apresentadas, como a do Instituto Brasileiro de Direito Processual e o projeto de novo Código de Processo Civil. 
Este último foi analisado até o fechamento deste trabalho em dezembro de $2013 \mathrm{e}$ qualquer outra mudança legislativa realizada após essa data não foi contemplada no estudo. De qualquer forma, examinamos a introdução da tutela de evidência no nosso ordenamento jurídico, claramente baseada no référé provision e a possibilidade de estabilização endoprocessual das tutelas de urgência e da tutela de evidência. Como dito, no capítulo 6, entendemos que o legislador perdeu a oportunidade de regular sobre a possibilidade de ser outorgada a coisa julgada para essas decisões, conferindo maior segurança jurídica às partes.

Desta maneira, depois de uma análise aprofundada sobre cada um destes temas, pesquisa doutrinária nacional e estrangeira, estudando sistemas jurídicos diferente dos nossos e sempre com o olhar atento a nossa realidade, esperamos que o objetivo deste trabalho tenha sido atendido. 


\section{REFERÊNCIAS BIBLIOGRÁFICAS}

ARAGÃO, Egas D. Hobbes Moniz de. Montesquieu e a teoria da ação. Revista de Processo, São Paulo, ano 27, n. 108, out.-dez. 2002.

ARIETTA, Giovanni. I provedimenti d'urgenza. Padova: Cedam, 1985.

ARMELIN, Donaldo. Tutela jurisdicional diferenciada. Revista de Processo, São Paulo, vol. 65, jan.-mar. 1992.

Ainda o procedimento monitório. Revista da Escola Paulista da Magistratura, São Paulo, vol. 2, n. 4, nov.-jun. 1998.

Apontamentos sobre a ação monitória: Lei 9.079.1995. Revista do Instituto de Pesquisas e Estudos, Bauru, n. 14, abr.-jul. 1996.

. Dos embargos de terceiro. Revista de Processo, São Paulo, vol. 62, 1991.

BARROSO, Darlan; ROSSATO, Luciano Alves. Mandado de segurança. São Paulo: Revista dos Tribunais, 2010.

BEDAQUE, José Roberto dos Santos. Tutela cautelar e tutela antecipada: tutelas sumárias e de urgência (tentativa de sistematização). 5. ed. São Paulo: Malheiros, 2009.

. Direito e processo: influência do direito material sobre o processo. 5. ed. São Paulo: Malheiros, 2009.

. Estabilização das tutelas de urgência. In: MORAES, Mauricio Zanoide de; YARSHELL, Flávio Luiz (orgs.). Estudos em homenagem à professora Ada Pellegrini Grinover. São Paulo: DPJ, 2005.

BONATO, Giovanni. I référés nell'ordinamento francese. In: CARRATTA, Antonio (org.). La tutela sommaria in Europa: studi. Napoli: Jovene Editore, 2012. 
BONÍCIO, Marcelo José Magalhães. Proporcionalidade e processo: a garantia constitucional da proporcionalidade, a legitimação do processo civil e o controle das decisões judiciais. São Paulo: Atlas, 2006.

BUENO, Cassio Scarpinella. O mandado de segurança contra ato judicial e o parágrafo único do art. 527 do Código de Processo Civil. In: CIANCI, Mirna et al. (orgs.). Temas atuais das tutelas diferenciadas: estudos em homenagem ao professor Donaldo Armelin. São Paulo: Saraiva, 2009.

BÜLOW, Oskar von. La teoria de las excepciones procesales y presupuestos procesales. Buenos Aires: Ediciones Jurídicas Europa-America, 1964.

BUONCRISTIANI, Dino. Sistema dei référés: tutela cautelare dal pregiudizio e tutela urgente senza pré-giudizio. Rivista Trimestrale di Procedura Civile, Milano, n. 2, giugno 2006.

CALAMANDREI, Piero. Introduzione allo studio sistematico dei provvedimenti cautelari. Padova: Cedam. 1936.

. Verità e verossimiglianza. Rivista di Diritto Processuale, Padova, 1955.

CAHALI, Yussef Said. Honorários advocatícios. 3. ed. São Paulo: Revista dos Tribunais, 1997.

CANOTILHO, J. J. Gomes. Direito constitucional e teoria da constituição. 7. ed. Coimbra: Almedina, 2003.

CAPPONI, Bruno. Sul procedimento sommario di cognizione nelle controversie societarie. In: CAVAllONE, Bruno; RICCI, Edoardo; SALETTI, Achille (orgs.). Studi di diritto processual civile in onore di Giuseppe Tarzia. Milano: Giuffrè Editore, 2005. tomo II.

CARNELUTTI, Francesco. Diritto e processo. Napoli: Morano. 1958.

. Lecciones sobre el proceso penal. Traducción de Santiago Sentis Melendo. Buenos Aires. 1950.

CARRATTA, Antonio. La tutela sommaria in Europa: studi. Napoli: Jovene Editore, 2012. 
Profili sistematici della tutela anticipatoria. Torino: Giapichelli Editore, 1997.

CAVAllONE, Bruno; RICCI, Edoardo; SALETTI, Achille (orgs.). Studi di diritto processual civile in onore di Giuseppe Tarzia. Milano: Giuffrè Editore, 2005. tomo II.

CHIOVENDA, Giuseppe. Instituições de direito processual civil. Tradução de J. Guimarães Menegale. Anotações de E. T. Liebman. 2. ed. São Paulo: Saraiva, 1965.

. Principii di diritto processuale civile. 3. ed. Napoli: N. Jovene, 1923.

CINTRA, Antônio C. Araújo; DINAMARCO, Cândido Rangel; GRINOVER, Ada Pellegrini. Teoria geral do processo. 21. ed. São Paulo: Malheiros, 2005.

COLA, Livia di. L'efficacia dei provvedimenti sommari nell'ordinamento tedesco. In: CARRATTA, Antonio (org.). La tutela sommaria in Europa: studi. Napoli: Jovene Editore, 2012.

COMOGLIO, Luigi Paolo. Garanzie costituzionali e "giusto processo" (modelli a confronto). Revista de Processo, São Paulo, ano 23, n. 90, abr.-jun. 1998.

Il giusto processo civile nella dimensione comparatistica. Revista de Processo, São Paulo, ano 27, n. 108, out.-dez. 2002.

. Tutela differenziatta e pari effettività nella giustizia civile. Rivista di Diritto Processuale, Milani, anno LXIII (seconda serie), n. 6. nov.-dic. 2008.

COMOGLIO, Luigi Paolo; FERRI, Corrado. La tutela cautelare in Italia: profili sistematici e riscontro comparativi. Rivista di Diritto Processuale, Padova, vol. 45, n. 4, ott.-dic. 1990.

COMOGLIO, Luigi Paolo; FERRI, Corrado; TARUFFO, Michele. Lezioni sul processo civile. Bologna: Il Mulino, 1998.

CONRADO, Paulo César. Efetividade do processo, segurança jurídica e tutela jurisdicional diferenciada. Revista do Tribunal Regional da $3^{a}$ Região, São Paulo, n. 76, mar.-abr. 2006. 
CONSTANTINO, Giorgio. Il nuove processo commerciale: la tutela cautelare. Rivista di Diritto Processuale, Padova, anno LVIII (seconda serie), n. 3, luglio-sett. 2003.

COSSIGNANI, Fabio. Il processo monitorio spagnolo: un processo sommario-plenario. In: CARRATTA, Antonio (org.). La tutela sommaria in Europa: studi. Napoli: Jovene Editore, 2012.

Brevi note in tema di tutela cautelare nella ley de enjuiciamento civil. In: CARRATTA, Antonio (org.). La tutela sommaria in Europa: studi. Napoli: Jovene Editore, 2012.

CIANCI, Mirna et al. (orgs.). Temas atuais das tutelas diferenciadas: estudos em homenagem ao professor Donaldo Armelin. São Paulo: Saraiva, 2009.

COUTURE, Eduardo J. Fundamentos del derecho procesal civil. Buenos Aires: Aniceto Lopez Editor, 1946.

DEBBIO, Cristiano Rodrigo Del. Tutela jurisdicional diferenciada: técnicas para sumarização da cognição. Dissertação (mestrado) - Faculdade de Direito, Universidade de São Paulo, São Paulo, 2005.

DENTI, Vittorio. La giustizia civile: lezioni introduttive. Bologna: Il Mulino, 1989.

DIDIER JÚNIOR, Fredie Didier Júnior; BRAGA, Paula Sarno; OLIVEIRA, Rafael. Distinção entre tutela antecipada e tutela cautelar. In: CIANCI, Mirna et al. (orgs.). Temas atuais das tutelas diferenciadas: estudos em homenagem ao professor Donaldo Armelin. São Paulo: Saraiva, 2009.

DINAMARCO, Cândido Rangel. A instrumentalidade do processo. 12. ed. São Paulo: Malheiros, 2008.

. A reforma do CPC. 3. ed. São Paulo, 1996.

. A reforma da reforma. Malheiros: São Paulo. 2003.

. Fundamentos do processo civil moderno. 3.ed. São Paulo: Malheiros, 2000. 
. Instituições de direito processual civil. São Paulo: Malheiros. 2001. vol. 2; 3.

. Tutela jurisdicional. Revista de Processo, São Paulo, ano 21, n. 81, jan. 1996.

DITTRICHI, Lotario. Dalla tutela cautelare anticipatoria alla tutela sommaria definitiva. In: Rivista di Diritto Processuale, Padova, anno XLIII, n. 3, 1988.

Presuposti e limiti. In: TARZIA, Giuseppe (org.). I procedimenti cautelari. Padova: Cedam, 1990.

DOUCHY-OUDOT, Mélina. Procédure civile. 4. ed. Paris: Gualino; Lextenso Éditions, 2010.

FABIANI, Massimo. Il rito cautelare societario (contraddizioni e dubbi irrisolti). Rivista di Diritto Processuale, Padova, anno LX (seconda serie), n. 4, ott.-dic. 2005.

FABRÍCIO, Adroaldo Furtado. Breves notas sobre provimentos antecipatórios, cautelares e liminares. Revista da Ajuris, Porto Alegre, vol. 66, 1994.

. Comentários ao Código de Processo Civil. 3. ed. Rio de Janeiro: Forense, 1988, vol. VIII.

FARIA, José Eduardo. Justiça e conflito. 2. ed. RT: São Paulo. 1992.

FAZZALARI, Elio. Istituzioni di Diritto Proessuale. Padova: Cedam, 1989.

FIGUEIRA JÚNIOR, João Dias. Comentários à novíssima reforma do CPC: lei n. 10.444, de 07.05.2002. Rio de Janeiro: Forense, 2002.

FINZI, Enrico. Questioni controverse in tema di esecuzione provvisoria. Rivista di Diritto Processuale, Padova, vol. II, 1926.

FRADEANI, Francesco. I pressuposti e gli effetti delle misure cauteari in Europa: l'esperienza francese ed inglese. In: CARRATTA, Antonio (org.). La tutela sommaria in Europa: studi. Napoli: Jovene Editore, 2012. 
FULGÊNCIO, Tito. Da posse e das ações possessórias. 9. ed. Atualizada por José de Aguiar Dias. Rio de Janeiro: Forense, 2000. vol. I.

FUX, Luiz. Tutela de segurança e tutela de evidência. São Paulo: Saraiva, 1996.

GARBAGNATI, Edoardo. Il procedimento d'ingiunzione. 4. ed. Milano: Giuffrè, 1970.

GARBI, Carlos Alberto. Tutela jurisdicional diferenciada e efetividade do processo. Revista dos Tribunais, São Paulo, ano 89, vol. 782, dez. 2000.

GARDELLA, Luis Luciano. Medidas autosatisfactivas: principios constitucionales aplicables. Trámite, recursos, medidas autosatisfactivas. Santa Fé (Argentina): Rubinzal Culzoni, 2007.

GONÇALVES FILHO, João Gilberto. O princípio constitucional da eficiência no processo civil. Tese (doutorado) - Faculdade de Direito, Universidade de São Paulo, São Paulo, 2010.

GRAZIOSI, Andrea. La cognizione sommmaria del giudice civile nella prospettiva delle garanzie costituzionali. Rivista Trimestrale di Diritto e Procedura Civile, Milano, vol. 63, n. 1, mar. 2009.

GRECCO, Leonardo. Cognição sumária e coisa julgada. IX Jornadas de Direito Processual, ago. 2012, Rio de Janeiro. São Paulo: IBDP, 2012.

GRINOVER, Ada Pellegrini. Considerações sobre os limites objetivos e a eficácia preclusiva da coisa julgada. Revista Síntese de Direito Civil e Processual Civil, São Paulo, ano III, n. 16, mar.-abr. 2002.

. O processo em sua unidade. Rio de Janeiro: Forense, 1984. vol. 2.

O processo: estudos e pareceres. 2. ed. DPJ: São Paulo, 2009.

GOLDSCHMIDT, James. Principios generales del processo. Buenos Aires: Edicciones Juridicas Europa América, 1961. vol. 1. 
GUERRA, Marcelo Lima. Estudos sobre o processo cautelar. 2. ed. São Paulo: Malheiros, 1997.

GUILLÉN, Víctor Fairen. El juicio ordinario y los plenarios rapidos: los defectos en la recepción del derecho procesal común; suscausas y consecuencias en doctrina y legislación actuales. Barcelona: Bosch, 1953.

IHERING, Rudolf von. O fundamento dos interdictos possessórios. Tradução de Adherbal de Carvalho. 2. ed. Rio de Janeiro: Livraria Francisco Alves, 1908.

JACOB NETTO, Fernando. Tutela processual da posse. Dissertação (mestrado) - Faculdade de Direito, Universidade de São Paulo, São Paulo, 2013.

JESTAZ, Philipe. L'urgence et les principes classiques du droit civil. Paris: Librairie Générale de Droit et de Jurisprudence, 1968.

JOMMI, Alessandro. Per un'efficace tutela sommaria dei diritti di obbligazione. Il référé provision. Rivista de Diritto Civile, Padova, anno XLIII, n. 1, genn.-febb. 1997.

KOMATSU, Roque. Da invalidade no processo civil. São Paulo: Revista dos Tribunais, 1991.

LEONEL, Ricardo de Barros. Eficácia imediata das sentenças e as reformas do CPC: um aspecto da caminhada para a efetividade da tutela jurisdicional. Revista Magister de Direito Civil e Processual Civil, Porto Alegre, ano 1, n. 3, nov. 2004.

. Tutela jurisdicional diferenciada. São Paulo: Revista dos Tribunais, 2010.

Tutela jurisdicional diferenciada no projeto de novo código de processo civil. Disponível em: <http://www2.senado.leg.br/bdsf/bitstream/handle/id/242950/000939997. pdf>, acesso em: 14 out. 2013.

LIEBMAN, Enrico Tullio. Problemi del processo civile. Milano: Morano Editore, 1964.

. Il principio del contraditorio nel processo civile. In: CENTRO NAZIONALE DI PREVENZIONE E DIFESA SOCIALE. La protezione giuridica del lavratore. Milano: 
Giuffrè, 1968. Apud TARZIA, Giuseppe. Il contraddittorio nel processo esecutivo, Rivista di Diritto Processuale, Padova, vol. 2, 1978.

Eficácia e autoridade da sentença e outros escritos sobre a coisa julgada. Traduão de Alfredo Buzaid e Ada Pellegrini Grinover. 3. ed. Rio de Janeiro: Forense, 1984.

LOPES, João Batista. Reforma do Judiciário e efetividade do processo civil. In: WAMBIER, Teresa Arruda Alvim et al. (orgs.). Reforma do Judiciário: primeiras reflexões sobre a Emenda Constitucional n. 45/2004. São Paulo: RT, 2005.

Antecipação da tutela e o art. 273 do CPC. Revista dos Tribunais, São Paulo, ano 85, vol. 729, jul. 1996.

LOPES, Bruno Vasconcelos Carrilho. Tutela antecipada sancionatória: art. 273, inc. II, do Código de Processo Civil. Malheiros: São Paulo. 2006.

LUGO, Jorge Carrión. La tutela jurisdiccional efectiva. Revista de Derecho y Ciencia Política, Lima, vol. 59, enero-jun. 2002.

MARCATO, Antônio Carlos. Procedimentos especiais. 14. ed. São Paulo: Atlas, 2010.

Ação de consignação em pagamento. 5. ed. Malheiros: São Paulo, 1994.

MARINONI, Luiz Guilherme. A reforma do CPC e a efetividade do processo (tutela antecipatória, tutela monitória e tutela das obrigacões de fazer e de não fazer). Revista do Tribunal Regional do Trabalho da $9^{a}$ Região, Curitiba, vol. 21, n. 1, 1996.

O direito à efetividade da tutela jurisdicional na perspectiva da teoria dos direitos fundamentais. Gênesis: Revista de Direito Processual Civil, n. 28, abr.-jun. 2003.

. Antecipação da tutela. 9. ed. São Paulo: RT, 2006.

. Tutela antecipatória e julgamento antecipado: parte incontroversa da demanda. 5. ed. São Paulo: Revista dos Tribunais, 2002. 
. Tutela antecipatória, julgamento antecipado e execução imediata da sentença. 4. ed. São Paulo: Revista dos Tribunais, 2000.

Técnica processual e tutela dos direitos. 3. ed. São Paulo: Editora RT, 2010.

MARKY, Thomas. Curso elementar de direito romano. 8. ed. São Paulo: Saraiva, 1995.

MEIRELLES, Hely Lopes; WALD, Arnoldo; MENDES, Gilmar Ferreira. Mandado de segurança e ações constitucionais. 35. ed. São Paulo: Malheiros, 2013.

MENCHINI, Sergio. Nuove forme di tutela e nuovi modi di risoluzione delle controversie: verso Il superamento della necessita dell'accertamento com autorità di giudicato. Rivista di Diritto Processuale, Padova, anno LXI (seconda serie), n. 3, luglio-sett. 2006.

MERLIN, Elena. I limiti temporali di efficacia. In: TARZIA, Giuseppe (org.). I procedimenti cautelari. Padova: Cedam, 1990.

MESQUITA, José Ignácio Botelho de. A coisa julgada. Rio de Janeiro: Forense, 2004.

MIRANDA, Francisco Cavalcanti Pontes de. Comentários ao Código de Processo Civil. Rio de Janeiro: Forense, 1977. tomo XV.

. Tratado da ação rescisória das sentenças e de outras decisões. 5. ed. Rio de Janeiro: Forense, 1976.

MONTESANO, Luigi. Strumentalità e superficialità della cognizione cautelare. Rivista di Diritto Processuale, Padova, vol. 54, n. 2, apr.-giugno 1999.

Luci ed ombre in leggi e proposte di tutele differenziate nei processi civile. Rivista di Diritto Processuale, Padova, anno XXXIV, n. 4, ott.-dic. 1979.

MORAES, Mauricio Zanoide de; YARSHELL, Flávio Luiz (orgs.). Estudos em homenagem à professora Ada Pellegrini Grinover. São Paulo: DPJ. 2005. 
MOREIRA, José Carlos Barbosa. A motivação das decisões judiciais como garantia inerente ao estado de direito. In: Temas de direito processual. São Paulo: Saraiva, 1988. série

2.

. Antecipação de tutela: algumas questões controvertidas. Revista Síntese de Direito Civil e Processual Civil, São Paulo, ano III, n. 13, set.-out. 2001.

. Efetividade do processo e técnica processual. Revista de Processo, Sao Paulo, vol. 20, n. 77, jan.-mar. 1995.

. Les principes fondamentaux de la procédure civile dans la nouvelle constitution brésilienne. In: Temas de direito processual. São Paulo: Saraiva, 1994. série 5.

- Miradas sobre o processo civil contemporâneo. In: Temas de direito processual. São Paulo: Saraiva, 1997. série 6.

. Tutela de urgência e efetividade do direito. In: Temas de direito processual civil. São Paulo: Saraiva, 2004. série 8.

Temas de direito processual. São Paulo: Saraiva, 1994. série 5.

NAVARRETE, Antonio Maria Lorca. El procedimiento monitorio civil. San Sebastián (España): Instituto Vasco de Derecho Procesal, 1988.

NERY JR., Nelson. Princípios do processo na constituição federal. 11. ed. São Paulo: RT, 2013.

OCTAVIANI, Eliane Avelar Sertorio. Tutela jurisdicional diferenciada e a efetividade do processo. Revista Jurídica, Campinas, vol. 15, n. 2, 1999.

OLIVEIRA, Carlos Alberto Alvaro de. Alcance e natureza da tutela antecipatória. Revista Forense, Rio de Janeiro, vol. 93, n. 337, jan.-mar. 1997.

. Efetividade e tutela jurisdicional. Revista Forense, Rio de Janeiro, vol. 101, n. 378, mar.-abr. 2005. 
. Efetividade e processo cautelar. Revista de Processo, São Paulo, ano 19, n. 76, out.dez. 1994.

Os direitos fundamentais à efetividade e à segurança em perspectiva dinâmica. Revista de Processo, São Paulo, ano 33, n. 155, jan. 2008.

Perfil dogmático da tutela de urgência. Revista Forense, Rio de Janeiro, vol. 94, n. 342, abr.-jun. 1998.

OLIVEIRA, Gleydson Kleber Lopes de. Ações possessórias enfoque sobre a cognição. São Paulo: Juarez de Oliveira, 2001.

PASSOS, José Joaquim Calmon de. Esboço de uma teoria das nulidades aplicada às nulidades processuais. Rio de Janeiro: Forense, 2002.

PEYRANO, Jorge W. La medida autosatisfactiva: forma diferenciada constituye una expresión privilegiada del proceso urgente. Génesis y evolución. Medidas autosatisfactivas. Santa Fé (Argentina): Rubinzal Culzoni, 2007.

PEREIRA, Alex Costa. Tutela sumára: a estabilização da tutela antecipada e sua adequação ao modelo constitucional do processo civil brasileiro. Tese (doutorado) - Faculdade de Direito, Universidade de São Paulo, São Paulo, 2012.

PISANI, Andrea Proto. La tutela sommaria in generale e il procedimento per ingiunzione nell'ordinamento italiano. Revista de Processo, São Paulo, vol. 23, n. 90, abr.-jun. 1998.

. Le tutele giurisdizionali dei diritti: studi. Napoli: Jovene Editore. 2003.

. Lezioni di diritto processuale civile. Napoli: Jovene Editore. 2012.

. Sulla tutela giurisdizionale differenziata. Rivista di Diritto Processuale, Padova, ano XXXIV, n. 4. ott.-dic. 1979.

. Verso la residualità del processo a cognizione piena? Revista de Processo, São Paulo, ano 31, vol. 131, jan. 2006. 
PUGLIESE, Giovanni. Polemica sobre la actio. Buenos Aires: Ediciones Jurídicas EuropaAmerica, 1974.

RAGONE, Alvaro J. D. Perez. Introducción al estudio de la tutela anticipatoria. Revista de Processo, São Paulo, vol. 81, jan.-mar. 1996.

REALE JÚNIOR, Miguel. Instituições de direito penal: parte geral. 2. ed. Rio de Janeiro: Forense. 2004. vol. I.

REDENTI, Enric; VELLANI, Mario. Diritto processuale civile. Milano: Giuffrè, 2000.

REDONDO, Bruno Garcia. Tutela jurisdicional. Revista de Processo, São Paulo, ano 35, n. 187, set. 2010.

RICCI, Edoardo. Verso un nuovo processo civile? Rivista di Diritto Processuale, Milano, vol. 58, n. $1,2003$.

Per una efficace tutela provvisoria ingiunzionale dei diritti di obbligazione nell'ordinario processo civile. Rivista di Diritto Processuale, Padova, anno XLV, n. 4, 1990.

A aplicação do art. 273 do CPC e seus principais aspectos: reflexões históricas e comparativas. In: MORAES, Mauricio Zanoide de; YARSHELL, Flávio Luiz (orgs.). Estudos em homenagem à professora Ada Pellegrini Grinover. São Paulo: DPJ, 2005.

RIGHI, Eduardo. Tutelas de urgência e efetividade do processo. Revista Forense, Rio de Janeiro, vol. 105, n. 401, jan.-mar. 2009.

RODRIGUES, Ruy Zoch. Embargos de terceiro. São Paulo: Revista dos Tribunais, 2006.

ROSENBERG, Leo. Tratado de derecho procesal civil. Traducción de Angela Romera Vera. Buenos Aires: Ediciones Juridicas Europa-America, 1955.

SAMPAIO, Rogério Marrone de Castro. Embargos de terceiro. Dissertação (mestrado) Faculdade de Direito, Universidade de São Paulo, São Paulo, 2003. 
SANTOS, Moacyr Amaral dos. Ações cominatórias no direito brasileiro. 5. ed. São Paulo: Malheiros; Max Limonad, 1973. tomo I.

SANTOS, Ernane Fidélis dos. Novíssimos perfis do processo civil brasileiro. Belo Horizonte: Del Rey, 1996.

SANTOS, Boaventura de Sousa. Para uma revolução democrática da justiça. 3. ed. Disponível em: <http://72.29.69.19/ ejal/images/stories/arquivos/RevDemJust FEV2011. pdf>, acesso em: 17.12.2013.

SATTA, Salvatore. Diritto processuale civile. 2. ed. Padova: Cedam, 1950.

SICA, Heitor Vitor Mendonça. O direito de defesa no processo civil brasileiro: um estudo sobre a posição do réu. São Paulo: Atlas, 2011.

SILVA. Ovídio A. Baptista da. A ação cautelar inominada no direito brasileiro. 4. ed. Forense: Rio de Janeiro, 1992.

. Curso de processo civil. 6. ed. São Paulo: Revista dos Tribunais, 2003. vol. 1; 3.

. Da sentença liminar à nulidade da sentença. Rio de Janeiro: Forense, 2002.

. O contraditório nas ações sumárias. Revista da Escola Paulista de Magistratura, São Paulo, vol. 2, n. 2, jul.-dez. 2001.

SOARES, Rogério Aguiar Munhoz. Tutela jurisdicional diferenciada. São Paulo: Malheiros, 2000.

TALAMINI, Eduardo. Tutela monitória: a ação monitória. Lei 9.079-95. 2. ed. São Paulo: Revista dos Tribunais, 2001.

Tutela de urgência no projeto de Novo Códigode Processo Civil: a estabilização da medida de urgência e a "monitorização" do processo civil brasileiro, Revista de Processo, São Paulo, ano 37, n. 209, julho - setembro 2012. 
TARZIA, Giuseppe. Considerazioni comparative sulle misure provvisorie nel processo civile. Rivista di Diritto Processuale, Padova, 1985.

. Curso de direito processual civil, 19. ed. Rio de Janeiro: Forense, 1997. vol. III.

(org.). I procedimenti cautelari. Padova: Cedam, 1990.

. Il contraddittorio nel processo esecutivo, Rivista di Diritto Processuale, Padova, vol. 2,1978 .

. L'art. 111 Cost. e le garanzie europee del processo civile. Revista de Processo, São Paulo, vol. 26, n. 103, jul.-set. 2001.

. Medidas cautelares atípicas. Tradução de Paulo Henrique dos Santos Lucon. Revista da Pós-graduação da Faculdade de Direito da Universidade de São Paulo, São Paulo, vol. 4, 2002.

THEODORO JÚNIOR, Humberto. A garantia fundamental do devido processo legal e o exercício do poder de cautela. Revista dos Tribunais, São Paulo, ano 80, vol. 655, mar. 1991.

. O mandado de segurança segundo a lei 12.01, de 07 de ago. de 2009. Rio de Janeiro: Forense, 2009.

.Tutela antecipada. Revista Juridica, Porto Alegre, vol. 45, n. 232, 1997.

TISCINI, Roberta. I provvedimenti decisori senza accertamento. Torino: G. Giappichelli Editore, 2009.

TOMMASEO, Ferruccio. I provvedimenti d'urgenza: struttura e limiti della tutela anticipatoria. Padova: Cedam, 1983.

TUCCI, José Rogério Cruz. Ação monitória: Lei 9.70 de 14.07.1995. 3. ed. São Paulo: RT, 2001. 
Ação monitória no novo processo civil português e espanhol. Revista de Processo, São Paulo, vol. 26, n. 103, jul.-set. 2001.

. Lições de história do processo civil romano. São Paulo: Revista dos Tribunais,1996.

. Tempo e processo. São Paulo: RT, 1998.

WAMBIER, Teresa Arruda Alvim. Da liberdade do juiz na concessão de liminares e a tutela antecipatória. In: (org.). Aspectos polêmicos da antecipação da tutela. São Paulo: RT, 1997.

WATANABE, Kazuo. Da cognição no processo civil. 3. ed. São Paulo: Perfil, 2005.

. Controle jurisdicional (princípio da inafastabiildade do controle jurisdicional no sistema jurídico brasileiro) e mandado de segurança contra atos judiciais. São Paulo: Revista dos Tribunais, 1980.

YARSHELL, Flávio Luiz. Tutela jurisdicional. São Paulo: DPJ, 2006.

. A Reforma do Judiciário e a promessa de "duração razoável do processo". Revista do Advogado, São Paulo, ano XXIV, n. 75, abr. 2004.

YOSHIKAWA, Eduardo Henrique de Oliveira Yoshikawa. Tutela de urgência definitiva? Medidas autossatisfativas (Argentina), medidas provisonais (Brasil) e a proposta de estabilização da antecipação de tutela. $1^{\circ}$ Congresso Argentina-Brasil de Direito Processual Civil, dez. 2012, São Paulo. São Paulo: Associação dos Advogados de São Paulo, 2012.

ZAVASCKI, Teori Albino. Reforma do sistema processual civil brasileiro e reclassificação da tutela jurisdicional. Revista Forense, Rio de Janeiro, 1999 n. 346, abr.-jun. 1999.

- Medidas cautelares e medidas antecipatórias: técnicas diferentes, função constitucional semelhante. Revista de Processo, São Paulo, vol. 21, n. 82, abr.-jun. 1996. 


\section{ANEXO I \\ Proposta de lei apresentada pelo Instituto Brasileiro de Direito Processual ${ }^{1}$}

Art. 273

$[\ldots]$

$\S 4^{\circ}$ - A tutela antecipada poderá ser revpogada ou modificada, fundamentadamente, enquanto não se produza a preclusão da decisão que a concedeu $\left(\S 1^{\circ}\right.$ do art. $273-\mathrm{B}$ e art. 273-C).

$\S 5^{\circ}$ - Na hipótese do inciso I deste artigo, o juiz só concederá a tutela antecipada sem ouvir a parte contrária em caso de extrema urgência ou quando verificar que o réu, citado, poderá torná-la eficaz.

Art. 273-A. A antecipação de tutela poderá ser requerida em procedimento antecedente ou na pendência do processo.

Art. 273-B. Aplicam-se ao procedimento antecedente, noq ue couber as disposições do Livro III, Título único, Capítulo I deste Código

$\S 1^{\circ}$ - Preclusa a decisão que concedeu a tutela antecipada, é facultado, no prazo de 60 (sessenta) dias:

a) Ao réu, propor demanda que vise à sentença de mérito;

b) Ao autor, em caso de antecipação parcial. Propor demanda que vise à satisfação integral da pretensão.

$\S 2^{\circ}$ - Não intentada a ação, a medida antecipatória adquirirá força de coisa julgada nos limites da decisão proferida.

Art. 273-C. Preclusa a decisão que concedeu a tutela antecipada no curso do processo é facultado à parte interessada requerer seu prosseguimento, no prazo de 30 (trinta) dias, objetivando o julgamento de mérito.

Parágrafo único. Não pleiteado o prosseguimento do processo, a medida antecipatório adquirirá força de coisa julgada nos limites da decisão proferidas.

Art. 273-D. Proposta a decisão que concedeu a tutela antecipada no curso do processo é facultado à parte interessada requerer seu prosseguimento do processo, a medida antecipatória adquirirá força de coisa julgada nos limites da decisão proferida."

1. Retirado de Ada Pellegrini Grinover, Tutela jurisdicional diferenciada: a antecipação e a estabilização, in: O processo: estudos e pareceres, p. 110. 
Art. 273-D. Proposta a demanda ( $\left(1^{\circ}\right.$ do art. 273-B) ou retomado o curso do processo (art. 273-C), sua eventual extinção, sem julgamento do mérito, não ocasionará a ineficácia da medida antecipatória, ressalvada a carência da ação, se incompatíveis as decisões. 
ANEXO II 
VIII - se houver também pedido subsidiário, o valor do pedido principal.

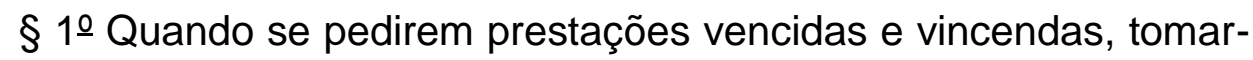
se-á em consideração o valor de umas e outras.

$\S 2$ 으 O valor das prestações vincendas será igual a uma prestação anual, se a obrigação for por tempo indeterminado ou por tempo superior a um ano; se, por tempo inferior, será igual à soma das prestações.

$\S 3$ 으 juiz corrigirá, de ofício e por arbitramento, o valor da causa quando verificar que não corresponde ao conteúdo patrimonial em discussão ou ao proveito econômico perseguido pelo autor, caso em que se procederá ao recolhimento das custas correspondentes; essa decisão é impugnável por agravo de instrumento.

Art. 294. O réu poderá impugnar, em preliminar da contestação, o valor atribuído à causa pelo autor, sob pena de preclusão; o juiz decidirá a respeito, impondo, se for o caso, a complementação das custas. A decisão do juiz que acolher a impugnação do réu é impugnável por agravo de instrumento, salvo se for um capítulo da sentença, quando então será impugnável por apelação.

\section{LIVRO V \\ DA TUTELA ANTECIPADA}

TÍTULO I

DAS DISPOSIÇÕES GERAIS, DA TUTELA DE URGÊNCIA E DA TUTELA DE EVIDÊNCIA

CAPÍTULO I

DAS DISPOSIÇÕES GERAIS

Art. 295. A tutela antecipada, de natureza satisfativa ou cautelar, pode ser concedida em caráter antecedente ou incidental.

Parágrafo único. A tutela antecipada pode fundamentar-se em urgência ou evidência.

Art. 296. A tutela antecipada requerida em caráter incidental independe do pagamento de custas. 
Art. 297. A tutela antecipada conserva sua eficácia na pendência do processo, mas pode, a qualquer tempo, ser revogada ou modificada.

Parágrafo único. Salvo decisão judicial em contrário, a tutela antecipada conservará a eficácia durante o período de suspensão do processo.

Art. 298. O juiz pode determinar as medidas que considerar adequadas para efetivação da tutela antecipada.

Parágrafo único. A efetivação da tutela antecipada observará as normas referentes ao cumprimento provisório da sentença, no que couber.

Art. 299. Na decisão que conceder, negar, modificar ou revogar a tutela antecipada, o juiz justificará as razões de seu convencimento de modo claro e preciso.

Parágrafo único. A decisão é impugnável por agravo de instrumento.

Art. 300. A tutela antecipada será requerida ao juízo da causa e, quando antecedente, ao juízo competente para conhecer do pedido principal.

Parágrafo único. Ressalvada disposição especial, na ação de competência originária de tribunal e nos recursos a tutela antecipada será requerida ao órgão jurisdicional competente para apreciar o mérito.

\section{CAPÍTULO II \\ DA TUTELA DE URGÊNCIA}

Art. 301. A tutela antecipada de urgência será concedida quando houver elementos que evidenciem a probabilidade do direito e o perigo na demora da prestação da tutela jurisdicional.

$\S 1$ ํ Para a concessão da tutela de urgência, o juiz pode, conforme o caso, exigir caução real ou fidejussória idônea para ressarcir os danos que a outra parte possa vir a sofrer; a caução pode ser dispensada se parte economicamente hipossuficiente não puder oferecê-la.

$\S 2^{\underline{\underline{o}}}$ A tutela antecipada de urgência pode ser concedida liminarmente ou após justificação prévia.

$\S 3$ o A tutela cautelar antecipada pode ser efetivada mediante arresto, sequestro, arrolamento de bens, registro de protesto contra alienação de bem e qualquer outra medida idônea para asseguração do direito. 
$\S 4$ Pode ser objeto de arresto bem indeterminado que sirva para garantir execução por quantia certa; pode ser objeto de sequestro bem determinado que sirva para garantir execução para a entrega de coisa.

Art. 302. A tutela antecipada de urgência não será concedida quando houver perigo de irreversibilidade dos efeitos da decisão.

Art. 303. Independentemente da reparação por dano processual, a parte responde pelo prejuízo que a efetivação da tutela antecipada cautelar causar à parte adversa, se:

I - a sentença lhe for desfavorável;

II - obtida liminarmente a tutela em caráter antecedente, não fornecer os meios necessários para a citação do requerido no prazo de cinco dias;

III - ocorrer a cessação da eficácia da medida em qualquer hipótese legal;

IV - o juiz acolher a alegação de decadência ou prescrição da pretensão do autor.

Parágrafo único. A indenização será liquidada nos autos em que a medida tiver sido concedida, sempre que possível.

Art. 304. Nos casos em que a urgência for contemporânea à propositura da ação, a petição inicial pode limitar-se ao requerimento da tutela antecipada satisfativa e à indicação do pedido de tutela final, com a exposição sumária da lide, do direito que se busca realizar e do perigo da demora da prestação da tutela jurisdicional.

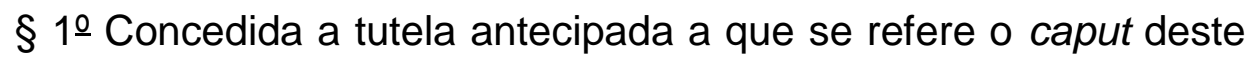
artigo:

I - o autor deverá aditar a petição inicial, com a complementação da sua argumentação, juntada de novos documentos e a confirmação do pedido de tutela final, em quinze dias, ou em outro prazo maior que o órgão jurisdicional fixar;

II - o réu será citado imediatamente, mas o prazo de resposta somente começará a correr após a intimação do aditamento a que se refere o inciso I deste $\S 1$ ․․ 
$\S 2$ 을 Não realizado o aditamento a que se refere o inciso I do $\S 1$ 은 deste artigo, o processo será extinto sem resolução do mérito.

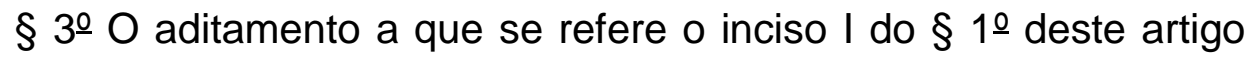
dar-se-á nos mesmos autos, sem incidência de novas custas processuais.

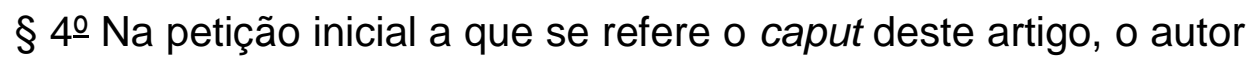
terá de indicar o valor da causa, que deve levar em consideração o pedido de tutela final.

$\S 5$ o $\bigcirc$ autor terá, ainda, de indicar, na petição inicial, que pretende valer-se do benefício previsto no caput deste artigo.

$\S 6$ 으 Caso entenda que não há elementos para a concessão da tutela antecipada, o órgão jurisdicional determinará a emenda da petição inicial, em até cinco dias. Não sendo emendada neste prazo, a petição inicial será indeferida e o processo, extinto sem resolução de mérito.

Art. 305. A tutela antecipada satisfativa, concedida nos termos do art. 304, torna-se estável se da decisão que a conceder não for interposto o respectivo recurso.

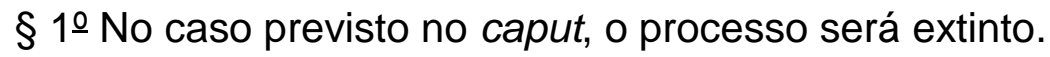

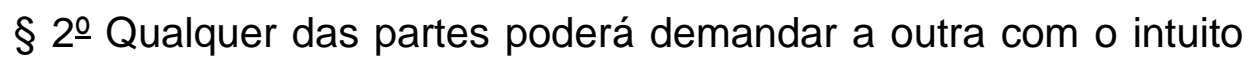
de rever, reformar ou invalidar a tutela antecipada satisfativa estabilizada nos termos do caput.

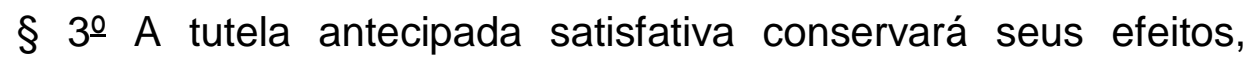
enquanto não revista, reformada ou invalidada por decisão de mérito proferida na ação de que trata o $\S 2$ ․․

$\S 4$ 으 Qualquer das partes poderá requerer o desarquivamento dos autos em que foi concedida a medida, para instruir a petição inicial da ação a

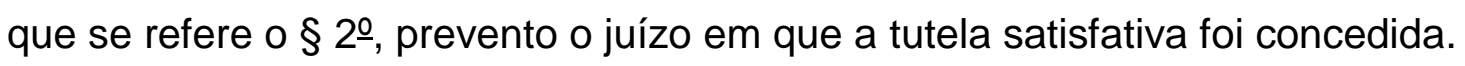

$\S 5$ o $O$ direito de rever, reformar ou invalidar a tutela antecipada,

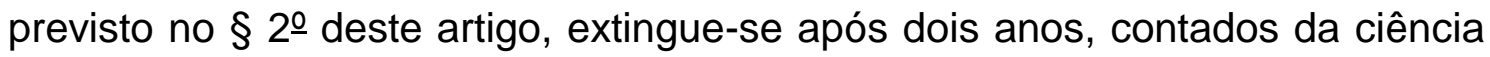
da decisão que extinguiu o processo, nos termos do $\S 1$ ㅇ.

\author{
CAPÍTULO III \\ DA TUTELA DA EVIDÊNCIA
}


Art. 306. A tutela da evidência será concedida, independentemente da demonstração de perigo da demora da prestação da tutela jurisdicional, quando:

I - ficar caracterizado o abuso do direito de defesa ou o manifesto propósito protelatório da parte;

II - as alegações de fato puderem ser comprovadas apenas documentalmente e houver tese firmada em julgamento de casos repetitivos ou em súmula vinculante;

III - se tratar de pedido reipersecutório fundado em prova documental adequada do contrato de depósito, caso em que será decretada a ordem de entrega do objeto custodiado, sob cominação de multa.

Parágrafo único. A decisão baseada nos incisos II e III deste artigo pode ser proferida liminarmente.

\section{TÍTULO II \\ DO PROCEDIMENTO DA TUTELA CAUTELAR REQUERIDA EM CARÁTER ANTECEDENTE}

Art. 307. A petição inicial da ação que visa à prestação de tutela cautelar em caráter antecedente indicará a lide, seu fundamento e a exposição sumária do direito que se visa assegurar e o perigo na demora da prestação da tutela jurisdicional.

Parágrafo único. Caso entenda que o pedido a que se refere o caput tem natureza satisfativa, o órgão jurisdicional observará o disposto no art. 304.

Art. 308. O réu será citado para, no prazo de cinco dias, contestar o pedido e indicar as provas que pretende produzir.

Art. 309. Não sendo contestado o pedido, os fatos alegados pelo autor presumir-se-ão aceitos pelo réu como ocorridos, caso em que o juiz decidirá dentro de cinco dias.

Parágrafo único. Contestado o pedido no prazo legal, observarse-á o procedimento comum.

Art. 310. Efetivada a tutela cautelar, o pedido principal terá de ser formulado pelo autor no prazo de trinta dias. Neste caso, será apresentado nos 
mesmos autos em que veiculado o pedido de tutela cautelar, não dependendo do adiantamento de novas custas processuais.

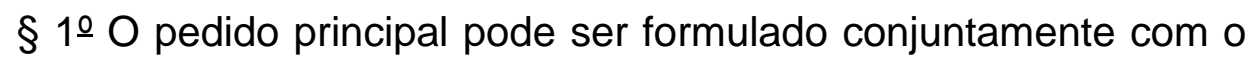
pedido de tutela cautelar.

$\S 2$ o A causa de pedir poderá ser aditada no momento da formulação do pedido principal.

$\S 3$ o Apresentado o pedido principal, as partes serão intimadas para a audiência de conciliação ou de mediação na forma do art. 335, por seus advogados ou pessoalmente, sem necessidade de nova citação do réu.

$\S 4$ 으 Não havendo autocomposição, o prazo para a contestação será contado na forma do art. 336 .

Art. 311. Cessa a eficácia da tutela concedida em caráter antecedente, se:

I - o autor não deduziu o pedido principal no prazo legal;

II - não for efetivada dentro de trinta dias;

III - o juiz julgar improcedente o pedido principal formulado pelo autor ou extinguir o processo sem resolução de mérito.

Parágrafo único. Se por qualquer motivo cessar a eficácia da tutela cautelar, é vedado à parte renovar o pedido, salvo sob novo fundamento.

Art. 312. O indeferimento da tutela cautelar não obsta a que a parte formule o pedido principal, nem influi no julgamento desse, salvo se 0 motivo do indeferimento for o reconhecimento de decadência ou de prescrição.

\section{LIVRO VI \\ FORMAÇÃO, SUSPENSÃO E EXTINÇÃO DO PROCESSO \\ TÍTULO I \\ DA FORMAÇÃO DO PROCESSO}

Art. 313. Considera-se proposta a ação quando a petição inicial for protocolada. A propositura da ação, todavia, só produz quanto ao réu os efeitos mencionados no art. 240 depois que for validamente citado. 